\title{
WestVirginiaUniversity
}

THE RESEARCH REPOSITORY @ WVU

Graduate Theses, Dissertations, and Problem Reports

2008

\section{Intrinsic and extrinsic factors that influence instructors' use of e- learning}

Salem A. Albalwi

West Virginia University

Follow this and additional works at: https://researchrepository.wvu.edu/etd

\section{Recommended Citation}

Albalwi, Salem A., "Intrinsic and extrinsic factors that influence instructors' use of e-learning" (2008). Graduate Theses, Dissertations, and Problem Reports. 2855.

https://researchrepository.wvu.edu/etd/2855

This Dissertation is protected by copyright and/or related rights. It has been brought to you by the The Research Repository @ WVU with permission from the rights-holder(s). You are free to use this Dissertation in any way that is permitted by the copyright and related rights legislation that applies to your use. For other uses you must obtain permission from the rights-holder(s) directly, unless additional rights are indicated by a Creative Commons license in the record and/ or on the work itself. This Dissertation has been accepted for inclusion in WVU Graduate Theses, Dissertations, and Problem Reports collection by an authorized administrator of The Research Repository @ WVU.

For more information, please contact researchrepository@mail.wvu.edu. 


\title{
Intrinsic and Extrinsic Factors that Influence Instructors' Use of E-learning
}

\author{
Salem A. Albalwi \\ Dissertation submitted to the \\ College of Human Resources and Education \\ at West Virginia University \\ in partial fulfillment of the requirements \\ for the degree of \\ Doctor of Education \\ in \\ Curriculum and Instruction \\ Perry Phillips, Ed.D., Chairperson \\ Sebastian Diaz, Ph.D., J.D. \\ Patricia Obenauf, Ed.D. \\ Steve Rinehart, Ed.D. \\ Ernest Goeres, Ph.D. \\ Department of Curriculum and Instruction \\ Morgantown, West Virginia 2008
}

\footnotetext{
Keywords: Intrinsic Factors, Extrinsic Factors, E-learning, and Instructors.

Copyright 2008 Salem A. Albalwi
} 


\title{
ABSTRACT
}

\section{Intrinsic and Extrinsic Factors that Influence Instructors' Use of E-learning}

\author{
Salem A. Albalwi
}

The purpose of the study was to determine whether significant differences exist among instructors at King Abdulaziz University's (KAU) Humanities and Scientific Colleges concerning their perceived levels of expertise and current use of e-learning technologies as part of their teaching. The proposed study also assessed influential factors (motivators and barriers) as measured by a survey questionnaire and examined them in terms of sex, academic field, and years of teaching experience.

Statistical methods of analysis for this study used means, standard deviations, frequencies, percentages, factor analysis, a 3way factorial ANOVA, and Scheffe's Post Hoc Analysis. Based on 227 responses, the findings indicate that instructors at KAU had a positive sense of technological expertise and categorized themselves as "proficient" (51.1\%), "expert"(12.5\%) and that there was a minimal use of e-learning technologies. Intrinsic factors proved to be more important than extrinsic factors for the motivational factors, and the reverse is true for the barriers.

There were several significant differences among instructors in the main effects and interactions regarding four dependent variables (expertise, current usage, motivation, and barriers) based on three independent variables (A) Sex, (B) Academic field, (C) Teaching experience, and the interactions of the variables together $(A B, A C$, $\mathrm{BC}$, and $\mathrm{ABC})$.

The significant differences reveal the influence of $A, B, C$, and the interactions of these variables with the four dependent variables: General expertise $-\mathrm{A}(\mathrm{F}=10.244 ; \mathrm{P}=0.002), \mathrm{B}(\mathrm{F}=$ $6.752 ; \mathrm{P}=0.010), \mathrm{C}(\mathrm{F}=3.078 ; \mathrm{P}=0.029)$, and interactions $\mathrm{AB}(\mathrm{F}=$ $8.989 ; \mathrm{P}=0.003)$ and $\mathrm{BC}(\mathrm{F}=3.540 ; \mathrm{P}=0.016)$; Specific expertise $\mathrm{A} \quad(\mathrm{F}=18.230 ; \mathrm{P}=0.000)$ and interactions $\mathrm{AB}(\mathrm{F}=7.216 ; \mathrm{P}=0.008)$ and $\mathrm{BC}(\mathrm{F}=2.998 ; \mathrm{P}=0.032)$; Current usage $-\mathrm{A}(\mathrm{F}=22.594 ; \mathrm{P}=$ $0.000)$ and interactions $\mathrm{AB}(\mathrm{F}=12.802 ; \mathrm{P}=0.000)$ and $\mathrm{BC}(\mathrm{F}=3.644 ; \mathrm{P}$ $=0.014)$; Motivation showed no significance; and Barriers, only A (F $=5.447 ; \mathrm{P}=0.021)$. Furthermore, this study provides a number of areas where additional research is needed in the future. 


\section{DEDICATION}

To mom, to the soul of my dad, to my kids, and to

all my family 


\title{
ACKNOWLEDGEMENTS
}

\section{The knowledge of which is only with my Lord. And of knowledge, you (mankind) have been given only a little (Holy Qura'n: Al-Isra Verse 85, p.290)}

\begin{abstract}
This study would not have existed without help, encouragement and cooperation of many people. My family, my friends, my colleagues, my professors and many others whom I cannot mentioned have helped me a lot in different ways to finish this research.
\end{abstract}

After the almighty Allah, and with deepest appreciation, I would like to thank Dr. Mohammad Al Rasheed, the Former Minister of Education in Saudi Arabia who gave me the opportunity to pursue my higher education in the USA. I am indebted to Dr. Al Rasheed to help bring my dream into reality. I would like also to thank Dr. Rabea Jan, the Chairman of Computer Department at Jeddah Teacher College for his belief in me. Rebea means spring in Arabic and Professor Rabea is like spring in his care, help, and passionate. Both Dr. Al Rasheed and Jan have a great impact on my life.

I am grateful for my advisor Dr. Perry Philips for his encouragement, guidance, and support. Dr. Perry wasn't only an adviser, but also a friend and a mentor. I would like also to thank my committee members Dr. Patricia Obenauf, Dr. Seastian Diaz, Dr. Steve Rinehart, and Ernest 
Goeres for their guidance during the writing of this dissertation. I have leaned a lot from each of them. I am also thankful faculty members at West Virginia University.

A special word of appreciation goes to Dr. Wafi Albalawi, Dr. Salaah Al Harbi Dr. Ali Al Qahtani, Dr. Osama Mukdadi, Dr. Ahmed El-Sherbeeny, and Mr. Ali Aljodea for their guidance and help.

I am sincerely grateful to Dr. James Harner chairman of Statistics Department at West Virginia University, Dr. Raid Amin and Dr. Subhash Bagui of Statistics Department at University of West Florida for their help in statistics

My deepest gratitude goes to my best friends Dr. Mishal Al Shammari and Mr. Charles Joukhadar for their sincere friendship. Mishal and Charles have done much for me during my stay in the US and made my life much easier.

A special word of thanks goes to my fellow doctoral student Dr. William White and Will Allendorfer. I have learnt a lot from them about the American education system.

In Saudi Arabia, I am thankful for administration and faculty members at King Abdulaziz University for their cooperation in collecting data. I am also grateful to Eng. Mohammad S. Albalawi for his help. A special word of thanks should go to Dr. Jamilaah H. Albalawi and Mrs. Saraah S. Albalawi of King Abdulaziz University. 


\section{TABLE OF CONTENTS}

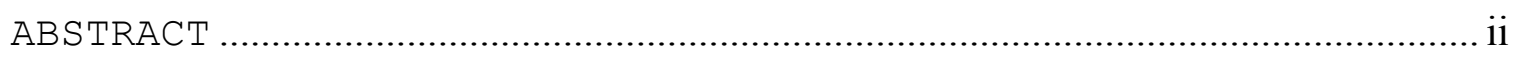

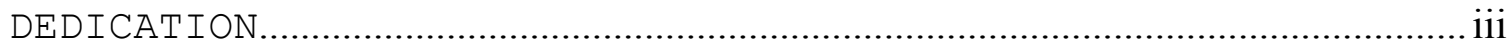

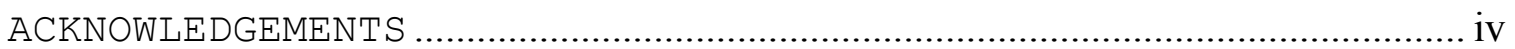

TABLE OF CONTENTS .......................................................................... vi

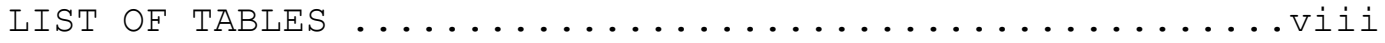

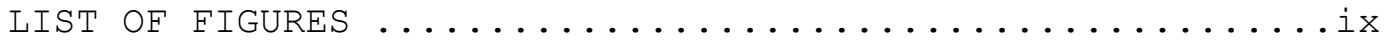

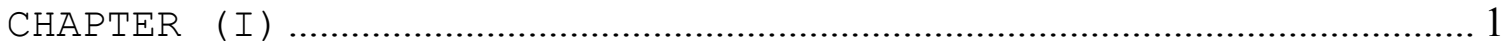

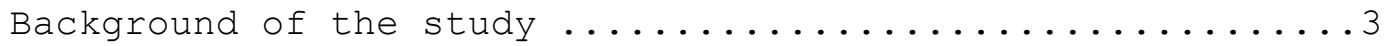

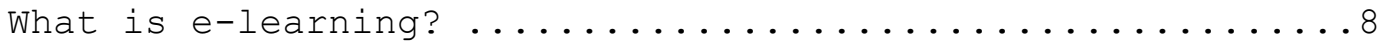

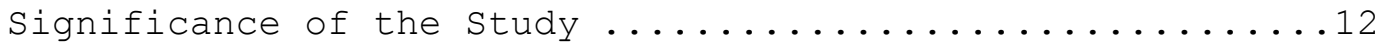

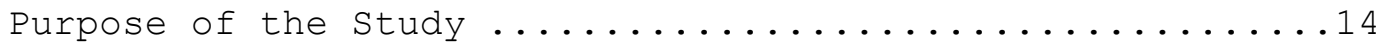

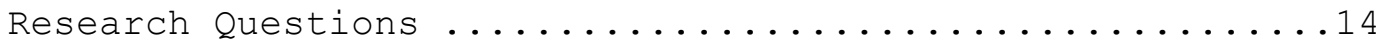

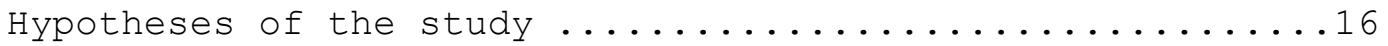

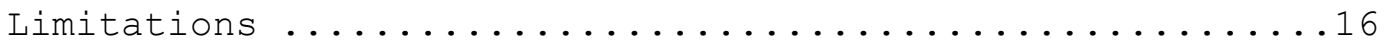

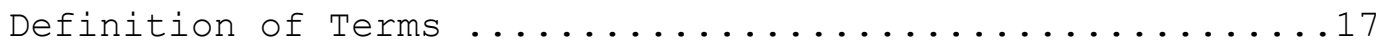

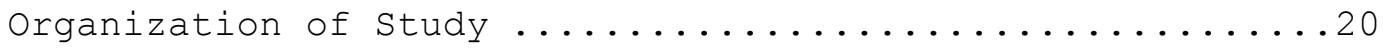

CHAPTER (II) .................................................................................. 21

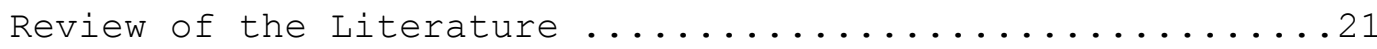

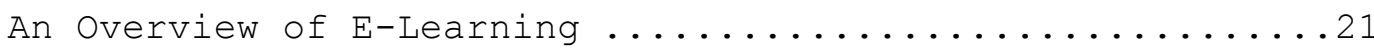

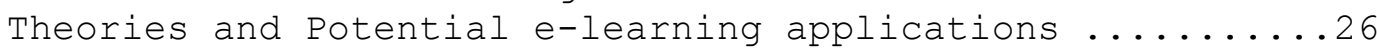

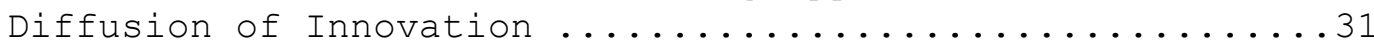

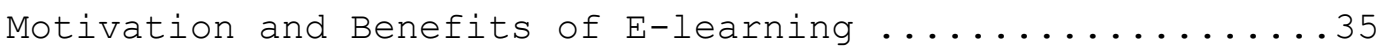

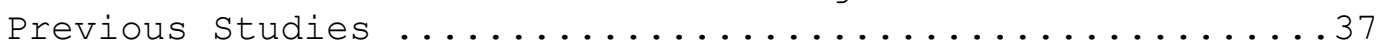

The Challenges and Barriers of E-Learning ..........47

Institutional challenges and barriers: .............................48

Instructor challenges : .......................................................... 52

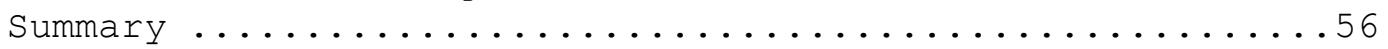

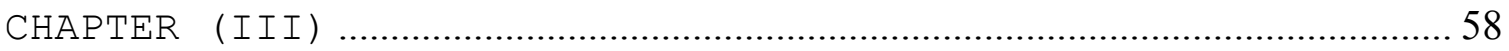

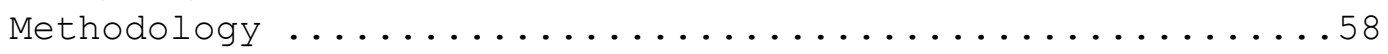

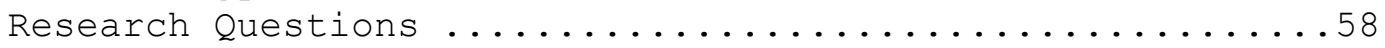

The first set of questions: ................................................... 58

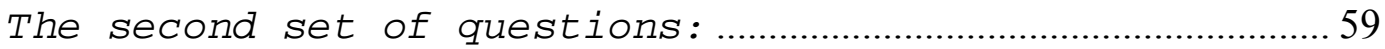

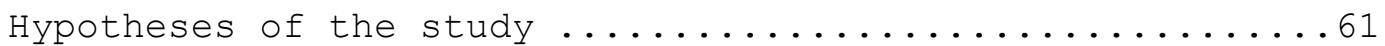

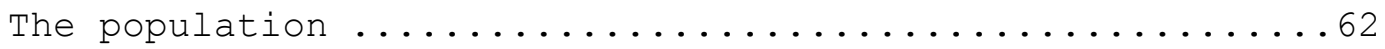

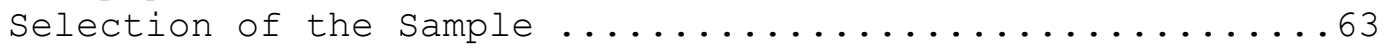

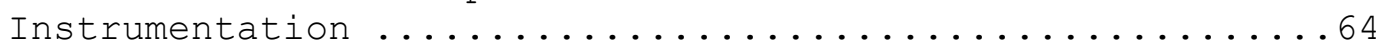

Validity and Reliability of the Instrument ..........69

Pilot study ........................................................................... 71

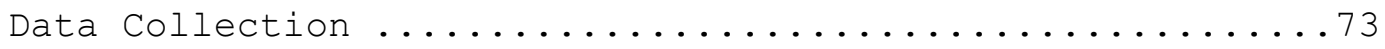

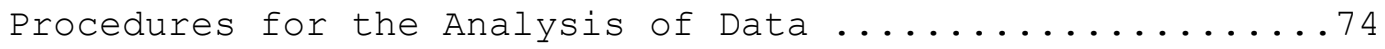

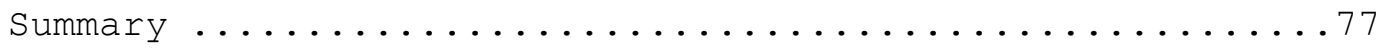

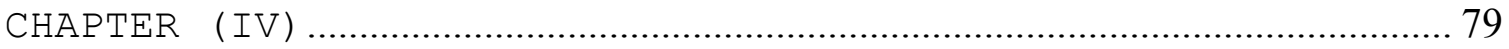

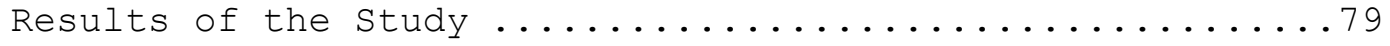

General Characteristics of the population and sample ...80

General expertise of participants: .................................... 85

Specific expertise of participants .......................................8 88

Motivation of participants ..................................................... 91 


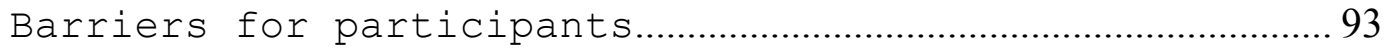

The result of factor analysis .....................94

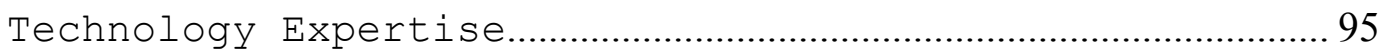

Current Use of e-Learning................................................................. 96

Motivation for Use e-Learning ...................................................... 97

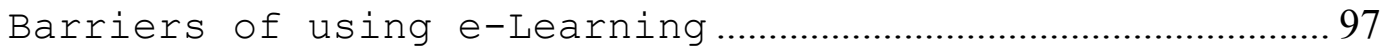

The results of inferential statistics ................100

General technology expertise ................................................... 102

Specific technology expertise ................................................... 106

Current Use of e-learning........................................................... 111

Motivational factors...................................................................... 116

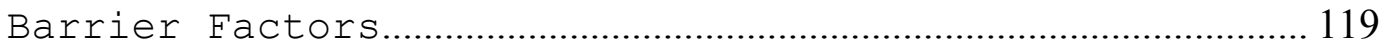

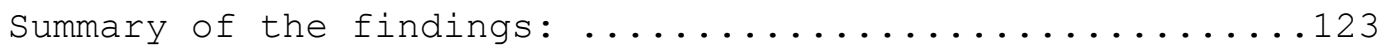

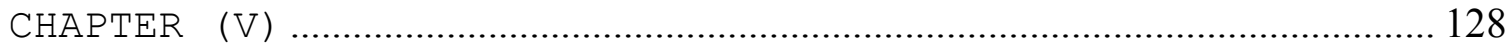

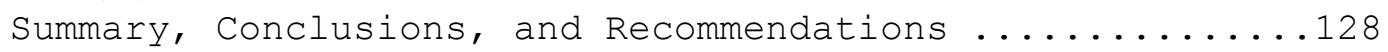

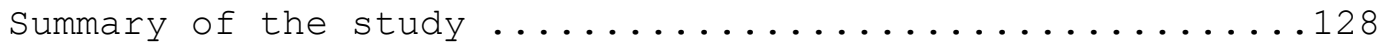

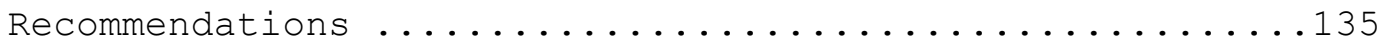

Recommendation for Future Research .........................

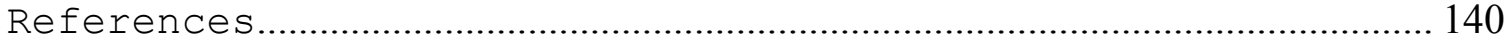

Appendix A: Survey Form (English Version) ...........150

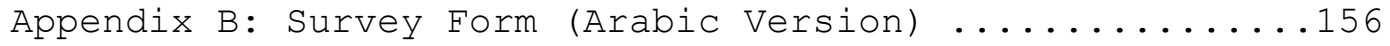

Appendix C: English Form of the Survey Evaluation .......162

Appendix D:Arabic Form of the Survey Evaluation ..........164

Appendix E: percentage of General Expertise by Academic

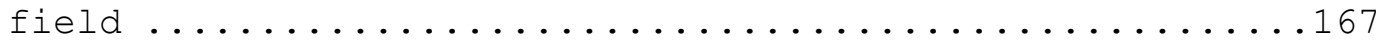

Appendix F: percentage of General Expertise by Sex .....168

Appendix G: 3-way Factorial ANVA for General Expertise ..169

Appendix I: 3-way Factorial ANOVA for Current Use .......190

Appendix J: 3-way Factorial ANOVA for Motivations .......200

Appendix K: 3-way Factorial ANOVA for Barriers ..........209

Appendix L: Factor Analysis for technology expertise ...218

Appendix M: Factor Analysis for current usage of e-learning

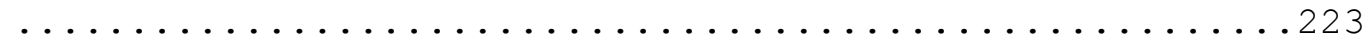

Appendix N: Factor Analysis for motivational factors ...230

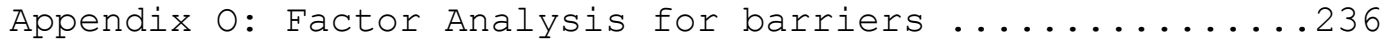

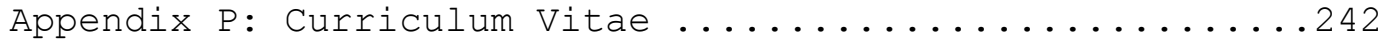




\section{LIST OF TABLES}

Chapter II:

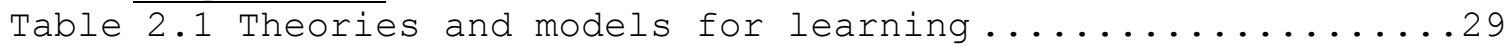

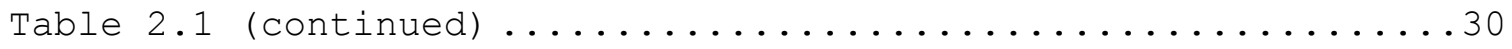
Chapter III:

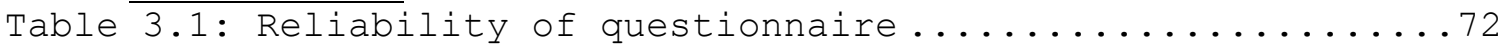

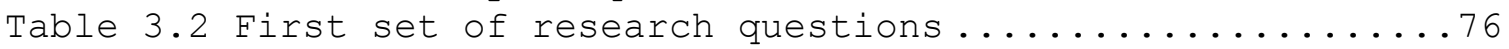

Table 3.3 Second set of research questions................77 Chapter IV:

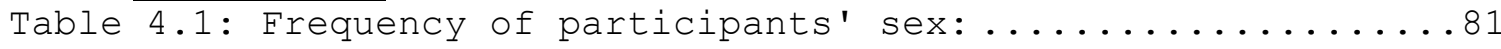

Table 4.2 : Frequency of participants' academic field:......81

Table 4.3 : Frequency of participants' experience:..........82

Table 4.4: Number of participants by their sex and academic field

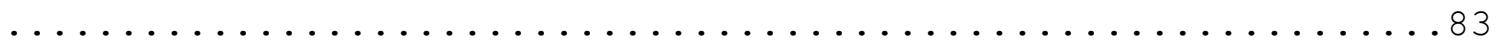

Table 4.5: Frequency of experience by academic field .......84

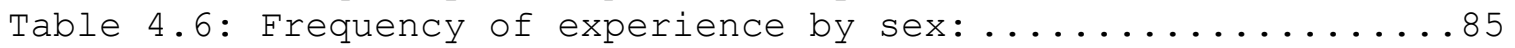

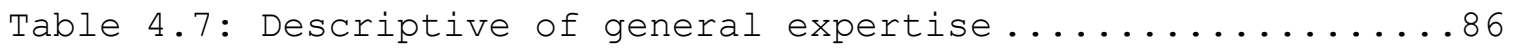

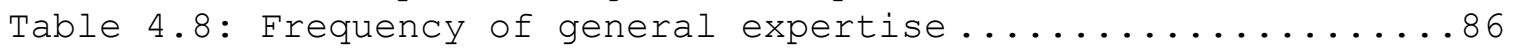

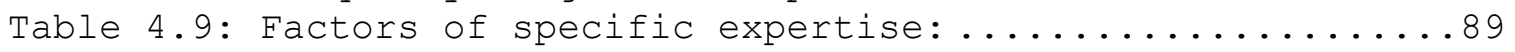

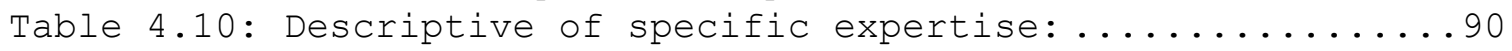

Table 4.11: Descriptive of current use e-learning............91

Table 4.12: Factors of current use of e-learning............91

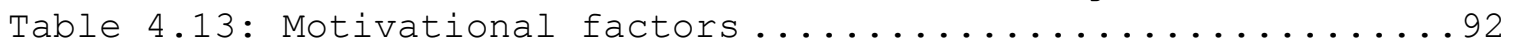

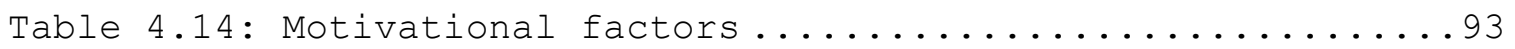

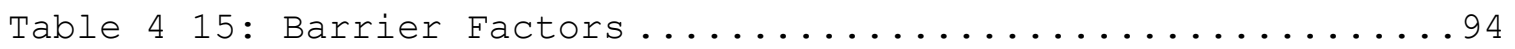

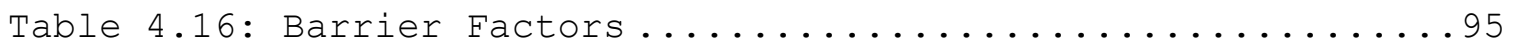

Table 4.17: KMO and Bartlett's test for technology expertise...96

Table 4.18: KMO and Bartlett's test for current usage of e-

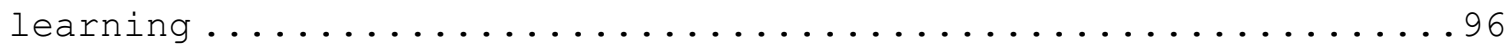

Table 4.19: KMO and Bartlett's test for motivation to use e-

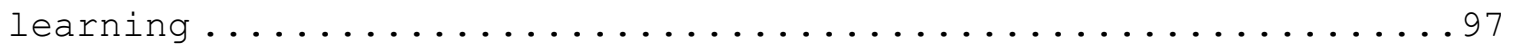

Table 4.20: KMO and Bartlett's test for barriers of using e-

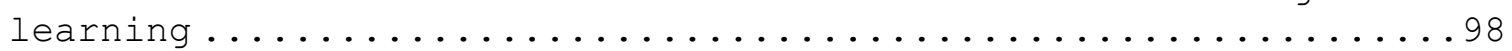

Table 4.21: Factors of specific expertise:.................99

Table 4.25 : 3-way Factorial ANOVA of Motivational Factors: ...119

Table 4.26: 3-way Factorial ANOVA of Factors Impeding .........123 


\section{LIST OF FIGURES}

Figure 1.1: A model of the relationship of e-learning with

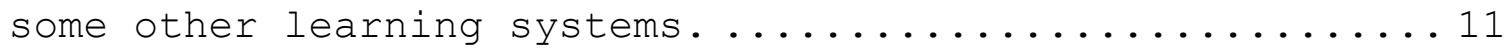

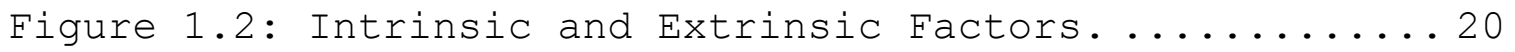
Figure 3.1: Tow dependent variables with three independent

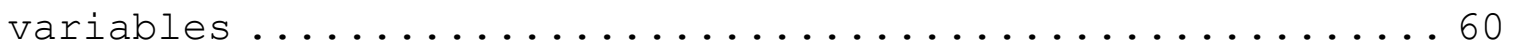
Figure 3.2: Tow dependent variables with three independent

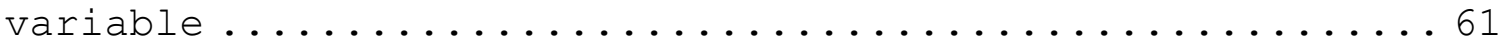
Figure 3.3: Instrumentation of the Study............64 Figure 3.4: Three independent Variables and four dependent

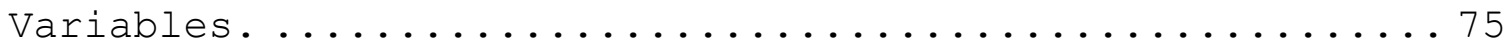
Figure 4.1: Frequency of years of teaching experience ...8 82 Figure 4.2: Frequency of participants by their sex and

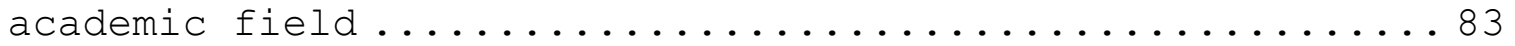

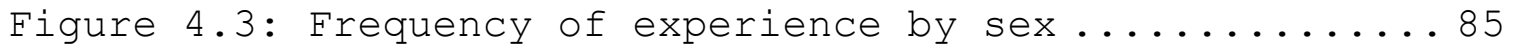
Figure 4.4: Frequency of general expertise..........87 Figure 4.5: Frequency of general expertise by academic

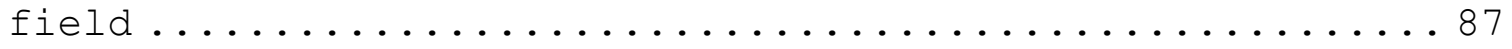
Figure 4.6: Frequency of general expertise by sex......88 Figure 4.7: Component plot in rotated space for expertise 99 


\section{CHAPTER (I)}

Since the beginning of human existence, mankind has sought to develop tools and improve methods that can be used to enhance his work and life. He invented preliminary tools for hunting, growing crops, and sewing clothes. The development continued during the industrial revolution in the sixteenth century until it reached its current state during the twenty-first century. The era of electronic technology started in the eighteenth century, and it has developed in five generations. The fifth generation has been called artificial intelligence. During this era the internet networks were invented in 1969. All of these inventions caused a rapidly growing revolution in communication and information technologies. This revolution formed many challenges for mankind in several aspects. One important aspect that has suffered from challenges in implementing new technologies is teaching and learning.

Without question, electronic technologies have been the greatest agent of change in this century and promise to play an increasing role in the coming decades. It is shifting every aspect of human life, including a system and policy of education. It is breaking old barriers and 
building new interconnections in the emerging Global Village. It has also become the chief determinant of upand-coming nations.

Civilized nations pay strong attention to improve education due to its importance to themselves and their generations. The educationalists have tried to develop the educational knowledge and skills of both the teachers and students. They have conducted research and studies to help both the instructors and the pupils to master these skills. The latest studies were conducted to see how technology can be best used in developing the education.

The developments in education, particularly elearning, have been synchronized with the development of computer and information technology. These developments, such as using multimedia visualization, computer-assistant learning, virtual classes, and video and audio conferences use the World Wide Web (WWW) for communications between people around the world, including instructors and students. In this study, we focused on determining and assessing the current use of e-learning by instructors in the Kind Abdul-Aziz University (KAU) in Saudi Arabia. We studied the factors that influence their use of e-learning. This study will hopefully yield improvements and provide 
solutions to many challenges that universities may face while implementing e-learning techniques.

\section{Background of the study}

Electronic technology is relatively new tool in education and is not expected to be embraced with open arms. That is, there is a normal tendency to resist new ways of doing things. E-learning is a recent innovation that has arisen with the technological computer revolution. Until only a few decades ago, technology consisted of chalkboards, overhead projectors, and printed pages, and today some professors are still using these methods of instruction. Many instructors are reluctant to abandon traditional methods, and the newer technologies are viewed by these individuals as supplementary tools to achieve educations goals. The decision of these instructors to use modern technology is not an outcome but rather a way to assist, enhance, and extend the educational experience (Green, 1997). This learning innovation is developing at a rapid pace and changes in the technology are happening daily. To many people this technology remains confusing because they are not yet comfortable with the innovations; however, countries and people are becoming increasingly 
dependent on this important technology. Conole \& Oliver (2007) discusses the effects and importance of e-learning:

"E-learning remains complicated, fast-moving and important. We cannot change that; nor can we 'solve' it. This is why it is a complicated but also such a fascinating, exciting area to be involved in - it is its blessing and its curse. What we have attempted to do here is to hold it in focus, to reveal and illuminate facets of this complex phenomenon that we are involved in both studying and producing. Its name may change; its characteristics might vary; different technologies and different practices might fall within its purview. This should not worry us; it is the hallmark of a vibrant, living field of research and practice. We do not fully understand it, and we will not fully understand it; but this should not stop us from trying to, nor from taking delight in the pursuit of understanding it." (p.223)

Today the impetus to move towards e-learning comes from both the supply and the demand sides of the situation. Instructors as well as educational institutions are interested in the "delivery" of courses that may be both cheaper and more efficient, but these methods may be less effective or satisfactory to the interests of the student. Students also want to use the most current materials, and these students request that modern technology be used in their education. However, although both the supply and the demand side of the situation are making requests to use 
more modern methods of instruction, the interests of both sides may not entirely coincide (Graham, 2004). Beller \& Or (1998) discuss the importance of integrating new learning technologies. They suggested that learning technologies provide a means for improving teaching methods in Universities and educational institutes by implementing electronic multimedia learning materials. These technologies also include visual simulations and demonstrations, accessibility to variety of knowledge data bases; continuous interaction between instructors and peers; and effective use of lessons for discussion. Therefore, new learning opportunities for higher education in particular are available as a result of the integration of these learning technologies.

However, distance learning may cause students to miss interaction with both their instructor and with other students in the class. This lack of interaction can prevent students from benefiting from the immediate behaviors of the instructors or other students and impacts student satisfaction ( Schultz, 2001; Fielder, 2003). (Jiang et al., 2006) comment on the need for students to interact with their instructor and claim that students value interaction with the instructor as a crucial element in online learning. New students have had a higher success 
rate in instructor-guided online courses than they have in self-study online courses. The first principle, which is of particular importance to e-learning, highlights the interaction between the student and instructor. In order to promote student motivation and involvement, students and instructors should have continual contact. This principle helps to explain why many students comment positively on instructor-guided courses.

Using different potential situations for schools in the future, possible scenarios have been suggested for the instructors, giving these instructors a position in national educational policies. Information and Communication Technology (ICT) influences teaching to become more of a profession rather than a vocation. The modern question not only concerns the improvement of education with the aid of ICT but also changes education and learning, as the rest of society is also transformed.

ICT impacts not only education but also society. It provides new and additional tools and methods to improve education, and it also changes society, education, and knowledge. Education is at the center of these transformations and is also transformed itself by ICT (Dowling \& Lai, 2003). The role of the instructor is changing, and the methods that the instructor implements 
are also changing. The instructor's role is becoming increasingly more demanding. We evaluate some of the ways that this role is developing, view how modern technologies force us to evaluate the essential roles of the instructor and reinforce specific elements of the profession, in particular the role of mediator, and the role in developing collective knowledge. Dowling \& Lai (2004) point out that the instructors must now deal with time and space in a different manner; they use modern instructional settings, which are increasingly global and unite pedagogy and academic life within its entirety. The increasing complexity and the transformations in education lead not only to the evolution of the teaching profession but also to additional teaching professions.

Around the world, higher education is being challenged to accomplish modern demands for the use of ICT to enhance the quality of education. Numerous criticisms of the traditional classroom are frequently encountered, including the lack of personal attention from the instructor, lack of motivation, outdated knowledge and materials, and the inappropriate nature of the instruction for a more diversified population (Gardiner, 1997; Hara \& Kling, 1999) 
The background information presented will address the definition of e-learning as well as the development of this technology around the world, in particular the Middle East. Many educators and educational policy makers do not fully understand the term "e-learning", but this technology is becoming a world phenomenon. Countries from around the world are beginning to use this technology to facilitate education, and the use of this e-learning is becoming crucial for advanced academic environments. The Middle East has begun to develop and integrate e-learning into educational systems, especially in higher education. Universities in the Middle East are beginning to understand the importance and usefulness of this technology, and the development of e-learning programs in these universities is increasing.

\section{What is e-learning?}

E-learning has many different definitions from experts in the field of technology. Some experts believe that elearning is focused on learning that takes place over long distances, such as the internet. However, not all long distance learning is considered e-learning and not all elearning is achieved over long distances. Other experts 
have argued instead that e-learning involves the use of any electronic technology for educational purposes.

Web technology professionals have defined E-learning, which is short for electronic learning, as an educational process that uses electronic communication technology. Some of these web technology experts consider e-learning to be defined as education and training delivered by an instructor or independently from a set of course materials stored on a database (Berry, 2000). Thus, these experts have defined e-learning as a personalized learning experience that provides measurable results in a web-based forum (Rich, 2001). E-learning programs include independent study, instructor guided web based training, knowledge, management, and performance support (Broadbent, 2000). Elearning refers to the use of internet technologies to deliver a wide variety of solutions that can enhance the students' knowledge and performance. Course solutions are networked, allowing for instant updates, retrieval, distribution and delivery to computer users using standard Internet technology (Rosenberg, 2001). E-learning has also been defined as any long distance instruction that uses electronic technology. For example, some experts have defined e-learning as any mode of distance-learning other 
than a correspondence course that uses printed material (Mantyla, 2001).

Other technology experts do not believe that elearning is limited to long distance learning or web-based forums. These experts believe that e-learning does not have to involve databases or networks. Instead, they argue that any information that is delivered, established or controlled by electronic technology for the explicit purpose of learning is also referred to as e-learning (Hicks, 2000). Web based professional have focused their definitions of e-learning on specific communications technologies such as interactive whiteboards, email, discussion boards, chat facilities, video conferencing, mobile and wireless tools (including mobile phones), Virtual Learning Environments (VLEs), and learning activity management systems. However, e-learning can also consist of information technologies that do not involve long distance communications such as stand alone desktop and laptop computers, software (including assistive software), video and audio tapes, and even digital cameras. Thus, e-learning should be defined as learning that occurs through the use of any Information and Communications Technologies (ICT). This definition does not limit e-learning to internet learning and does not confuse e-learning with long distance 
learning. As shown in Figure (1.1), e-learning contains both computer-based learning and online learning and serves as only a portion of the available methods for distance learning.

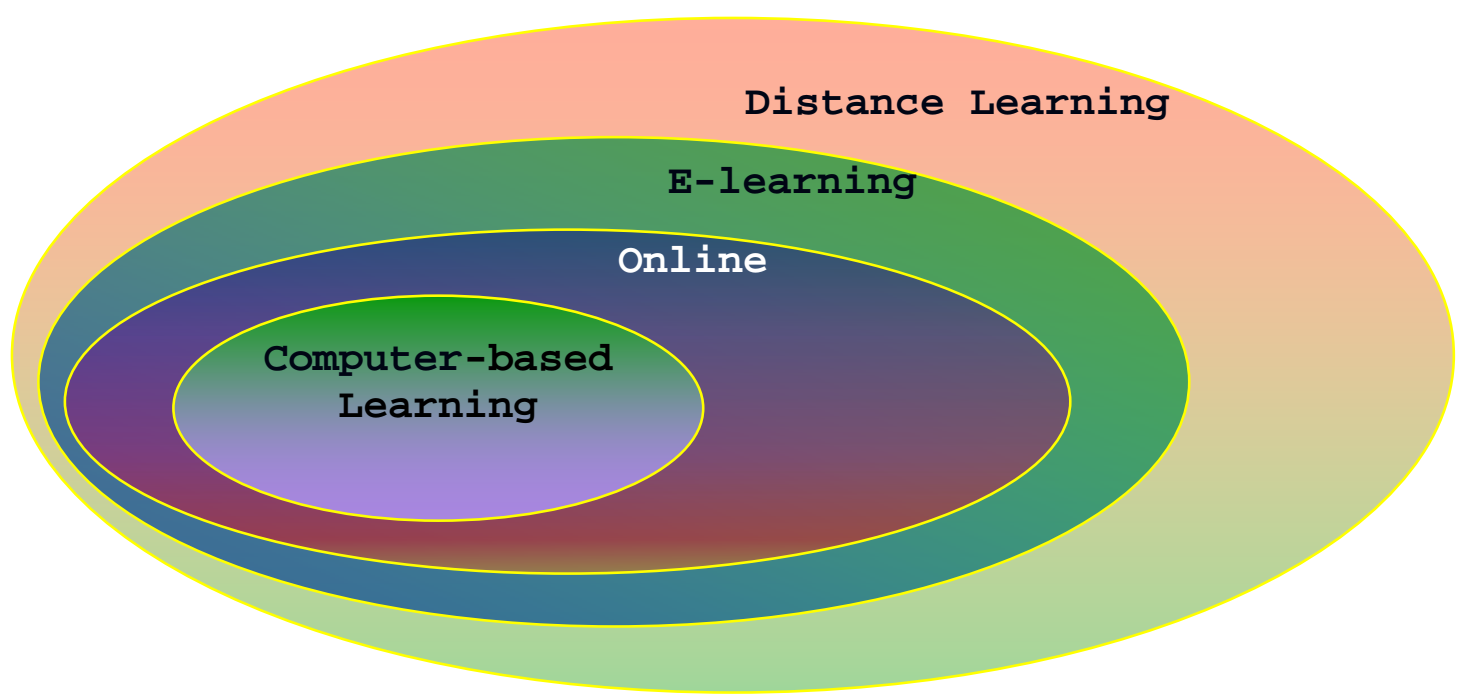

Fig 1.1: A model of the relationship of e-learning with some other learning systems.

E-learning can cover a spectrum of activities from electronic resources that facilitate learning to learning that is delivered entirely online as well as blended learning methods that use a combination of traditional and e-learning practices. However, whatever the technology is that is being used, learning is the vital element. Elearning is no longer simply associated with distance or remote learning, but forms part of a conscious choice of the best and most appropriate ways of promoting effective learning on the part of the instructor. 
There are three types of e-learning. The first one is the synchronous learning. Synchronous learning takes place in real-time. It is a virtual online classroom that allows classes, discussions, and collaboration to be done via a website for users from different places in real-time. The participants can communicate and participate online with a live instructor as well as other students (Maxey, 2002). The second kind of e-learning is the asynchronous learning. Asynchronous learning does not take place in real-time. It can be accessed at any time. Synchronous learning offers both instructor and learners real time environment therefore, both need to meet at a determined time. It is similar to traditional classroom and all interactions take place in real time. (Oates, \& Rengarajan, 2002).

Blended learning is third type of e-learning. It combines both characteristics of classroom and e-learning (Voci \& Young, 2001). Example of blended learning is IBM's Basic Blue program that includes wide and different elearning modules and supported online (IBM, 2004).

\section{Significance of the Study}

In spite of the fact that some higher-educational institutes in Saudi Arabia have recently applied e-learning 
methods to the teaching process, there is a significant need for performing studies and research in this area to improve the application of e-learning efficiently and effectively. (Cooper \& Zmud, 1990) indicate that by incorporating new and varied instructional technologies a necessity is created for researching the potential factors that affect the spread and use of these technologies. Due to the fact that many institutions are only beginning to implement instructional technologies, it is necessary for these institutions to understand the factors that affect the growth and implementation of e-learning technologies.

The objective of this research is to identify strengths and deficiencies that institutes may have which will respectively advance or impede the use of e-learning techniques. The significance of this study is to assess the current usages of e-learning and to determine the factors that influence the e-learning process. The outcomes of this study are intended to serve as recommendations and suggestions for applying the best strategies that could help higher-educational institutes in Saudi Arabia to adopt and use e-learning in their educational process more efficiently and effectively. These outcomes could reflect the integration of e-learning to the educational processes of these institutions so that they will be able to achieve 
short and long term goals. This study may also provide pathways for investigators to perform future studies in elearning and other related educational disciplines.

\section{Purpose of the Study}

The purpose of the study is to determine whether significant differences exist among instructors from King Abdulaziz University's (KAU) Humanities and Scientific Colleges concerning their perceived levels of expertise and current use of e-learning technologies as part of their teaching. The proposed study will assess influential factors (motivational and barrier factors) as measured by a survey questionnaire. This study will examine these factors in terms of sex, years of teaching experience, and academic field.

\section{Research Questions}

The study addresses the following research questions:

\section{The first set of questions:}

1. What are instructors' perceived levels of technology expertise?

2. What is the current use of e-learning by the instructors of the King Abdulaziz University? 
3. What are the intrinsic and extrinsic factors that motivate the instructors to use e-learning in their teaching?

4. What are the intrinsic and extrinsic factors that impede the instructors' use of e-learning in their teaching?

\section{The second set of questions:}

1- Is there a significant difference in the perceived technology expertise of instructors based on main effect (A) sex, (B) academic field, (C) teaching experience, and Interaction ( $A B, A C, B C, A B C)$ ?

2- Is there a significant difference in the use of e-learning among instructors based on main effect (A) sex, (B) academic field, (C) teaching experience, and Interaction $(\mathrm{AB}, \mathrm{AC}, \mathrm{BC}, \mathrm{ABC})$ ?

3- Is there a significant difference in motivational factors among instructors based on main effect (A) sex, (B) academic field, (C) teaching experience, and Interaction $(A B, A C, B C, A B C)$ ?

4- Is there a significant difference in barrier factors among instructors based on main effect (A) sex, (B) academic field, (C) teaching experience, and Interaction $(A B, A C, B C, A B C)$ ? 


\section{Hypotheses of the study}

The following null hypotheses, based on the second set of the questions, will be answered. They are:

Ho1: There is no significant difference in the technology expertise of instructors based on main effect (A) sex,

academic field, (C) teaching experience, and Interaction $(A B, A C, B C, A B C)$.

Ho2: There is no significant difference in the use of elearning by instructors based on main effect (A) sex,

academic field, (C) teaching experience, and Interaction $(A B, A C, B C, A B C)$.

Ho3: There is no significant difference in motivational factors among instructors based on main effect (A) sex, (B) academic field, (C) teaching experience, and Interaction $(A B, A C, B C, A B C)$.

Ho4: There is no significant difference in barrier factors among instructors based on main effect (A) sex, academic field, (C) teaching experience, and Interaction $(A B, A C, B C, A B C)$.

\section{Limitations}

There are limitations to this study. Therefore, any results reported in this investigation may not be fully generalized to other studies and disciplines. These 
limitations should be understood as recommendations of potential areas for further research. Limitations of this study include:

1. The study focuses only on instructors at (KAU) and does not include students, administrators, or support staff in the population.

2. The study was limited to (KAU) and results may not be able to be generalized for all other institutions of higher education.

3. The participants' responses on the survey may also not be clearly given or may have been given irresponsibly.

4. The study includes only current use, expertise, motivations, and barriers as dependent variables and three independent variables, including academic field, years of experience, and sex. The study does not consider all aspects of training or all possible psychological influences on behavior that might exist, such as all possible aspects of interest.

\section{Definition of Terms}

The following definitions were used to clarify and describe the terms upon which the discussion in this study was based. Definitions were also provided to establish the 
intended meanings of terminology and to promote understanding for future replication of the study.

E-learning: defined e-learning as the delivery of content via all electronic media, including the Internet, intranets, extranets, satellite broadcast, audio/video tape, interactive TV, and CD-ROM(Urdan, 2000).

Expertise: expertise is a multifaceted phenomenon. To a large extent, it is a cognitive phenomenon, but it is not exclusively a cognitive one. Expertise involves both general and specific processes, as well as knowledge and the ability to organize it. Also, expertise consists of those characteristics, skills and knowledge of a person (that is, expert) or of a system, which distinguish experts from novices and less experienced people.

Expertise as Technical Skill: The definition of expertise derives from the specific tasks a professional must perform. Most professional programs teach specific skills; thus, expertise is not simply the knowledge of the existence of general principles. Instead, expertise is the ability to recognize the cases to which these principles apply (McGlothlin, 1960) .

Motivation: The definition of (Smith, 1995) stating that motivation is "the inner stimulus that causes people to be energized and directed in their behavior"(Smith \& 
Luckasson, 1995,pp.241-295). According to (Vroom, 1964), the motivation of person to achieve a target is the belief that the performance and dealings will likely lead to a positive result. (Wolters, 1998) defined motivation as variables that stimulate or guide behavior in a specific path to achieve a target.

Intrinsic and Extrinsic Motivation: Intrinsic motivations come from inside an individual. For example, instructors may use e-learning because it is personally satisfying and enjoyable. In contrast, extrinsic motivations come from the environment around the person. For example, instructors are extrinsically motivated by increases in their salary or other rewards. As shown in Fig.1.2. Motivators can be positive or negative. Positive motivators encourage behavior and include benefits that exist. Negative motivators discourage behavior and include barriers as defined in the survey. For the purpose of this study, selected intrinsic and extrinsic variables, both positive and negative, are considered to be the form of motivation that has an effect on instructors' use of elearning in their teaching. 


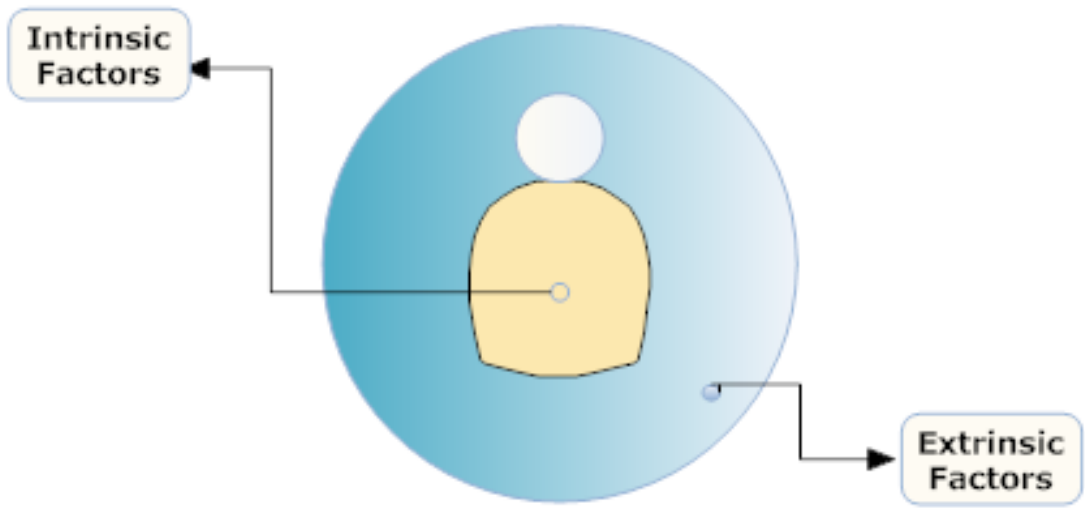

Figure1.2: Intrinsic and Extrinsic Factors.

\section{Organization of Study}

This study consists of five chapters. The first chapter contains the introduction, background, statement of purpose, research questions, research hypotheses, significance of study, limitations of the study, and the organization. Chapter two provides a review of literature related to instructors' use of e-learning in their teaching as well as the factors that influence their usage. Chapter three deals with the methodology used to conduct the study. Chapter four contains the results and analysis of the study. Finally, chapter five contains the summary and discussion of the results and recommendations. 


\title{
CHAPTER (II) \\ Review of the Literature
}

\begin{abstract}
The objective of this chapter is to review previous literature and research relevant to this study. This includes examining the influencing factors on instructors' use of e-learning in delivering instruction. In addition, this includes mentioning variables and concepts of the study, which will include a general perspective on elearning, motivational factors, relevant theories, and challenges and barriers that face instructors and institutions in the use of e-learning.
\end{abstract}

\section{An Overview of E-Learning}

Technological development is a major influence of change in the current environment. The significance of this development shows that an institution's lack of recognition of the strategic value of technology threatens the ability of this institution to survive the transition into the communication and Information Age (Rowley et al., 1998). As an influence of change, technology has dramatically altered many processes and values in universities educational systems. (Armstrong, 2000) indicates that the rapidly developing achievements of technology, for both communication and learning, are inspiring organizational 
evolution and cultural shifts. However, some academics may view distance learning as a disruptive technology. The methods of instruction, interaction, communication, support, and learning are developing rapidly based on technological advances (Jones, 2000). Within this rapidly developing environment of not only technology but also new learner needs and expectations, higher educational institutions are working to maintain traditional values and missions while developing as a union for an unobserved future.

Many people whether inside or outside education field still think that technology in classrooms represented by computers has been oversold and underused (Foster \& Cass, 2002; Islam, 2002; Segers, 2002). Other studies indicate that most computer assisted learning software packages are not yet of commercial quality, and there are still many unanswered questions, especially concerning the application of modeling instructional situations realistically enough so that authoring tools for these situations can satisfy widespread demands (Murray, 1999). Some skeptics question the nature of successful technological and pedagogical advances for two reasons: technological thinking and social trends, or viewpoints (Espinosa et al., 2005). 
The first set of motives concerns technological thinking. Balancing computer science innovation with academic and teaching goals has been a particular problem for research and commercial groups that evaluate computerassisted learning. Kuljis and Lees state that "whereas most research projects attempt to implement the most recent technological developments, commercial products seem to focus in providing efficient e-Learning solutions using already available solutions"(Kuljis \& Lees, 2002). Thus, complex artificial intelligence developments can seem to provide no educational benefit in actual classroom situations; for example, the use of adaptive web content generators for e-learning. The pedagogical design of commercial products is often instructional and, thus, based on textbooks. This design occurs even in multimedia and virtual reality environments. (Espinosa et al., 2005) demonstrate that students do not always consult these online references and, instead, may prefer traditional content sources, such as photocopied materials from books and class notes in PowerPoint format. In addition, overused artificial intelligence or instructional software is not always the best solution for assisting learning, because people often learn with unpredictable methods that can be unseen by the technological developer(Heath, 1997). For 
example, many people would rather chat than post items to a discussion board or use some other highly developed learning environment when working on a project over long distances, because it seems more 'personal'', and occurs in real-time (Espinosa et al., 2005).

The second set of motives is concerned with social sciences and humanities. Research in these fields has not been able to fully demonstrate that students are motivated to learn when the instructor applies the cognitive science theories of Piaget and Vygotsky in face-to-face activities (Cook et al., 2002; Wilson, 2001). Accordingly, the overall goal may become lost, and many instructors achieve few benefits from adopting these new strategies, as compared to the traditional way.

Many institutions have sought and secured web-based alternatives to their face-to-face courses. Higher education has gone through a huge transformation. Thompson (2000) states that there is "a rapid transition [occurring] from traditional approaches to education to forms of online delivery" (p. 154). Moreover, Davis states that "online learning is now becoming ubiquitous at all levels of education, in all institutions of learning, and in the workplace" (Davis, 2004). Despite all of the advantages that web-based learning offers for educational 
institutions, their required capacity to supply a new technological platform have not improved without additional challenges and barriers. (Davis, 2004) explains that many of these challenges arise from the institutions' need to alter their whole infrastructures:

"Building the infrastructure for online learning requires that many factors be considered, so it is difficult to provide a straightforward checklist or recipe to follow. All educational endeavors are systems, made up of various interconnected components. In traditional universities and colleges, instructors can be unaware of all the complexities involved, but in distance education, understanding how the entire system of course development and delivery occurs, and how these systems link to services and other components, are vital aspects of ensuring effectiveness and quality." (pp. 97-98).

The intrinsic motivators may provide more incentive for instructors and students to incorporate technology in elearning. (Lonsdale, 1993) outlines several general principles from motivation theory that concern instructors. He notes that in an academic environment intrinsic satisfaction is more effective in influencing motivation and performance than extrinsic factors. Additionally, (Taylor \& White, 1991) found this to also be true in regard 
to distance learning; instructors were motivated to teach in these distance e-learning programs more by intrinsic than extrinsic motivators.

\section{Theories and Potential e-learning applications}

Many forms of e-learning claim to be constructed from theoretical designs, such as constructivism, without explaining how these principles and values are embodied in the approach (Conole et al., 2004). Thus, many designs are actually based on 'common-sense' rather than using a theoretically based construction. However, perhaps a more theoretically based approach to e-learning design would better relate theory with the intended features of learning and then connect appropriate tools and resources (both human and technical) with these features. This approach could enable practice to reflect the basic underlying theory

There are many schools of educational thought and learning theories. Many theories can be divided into three educational categories: behaviourism, socio-cultural, and constructivism. In addition, many other models for learning have been suggested, including Jarvis' model of reflection and learning (Jarvis, 1987), Kolb's experiential learning cycle, this model is based on the studies of John Dewey, 
Kurt Lewin, and Piaget (Kolb, 1984), Laurillard's conversational framework, which includes discursive, adaptive, interactive and reflective components (Laurilard, 2002) and Barnet's framework for higher education (Barnett, 1990). Each model has its own focal point and emphasis and is connected with a specific set of theoretical viewpoints. Therefore, each model has individual benefits that can be used to develop particular aspects of learning. With respect to e-learning, practitioners should be enabled to easily use the full range of available models or perspectives on learning, but there is currently little proof on how these models or theories can be applied to successful pedagogically driven e-learning (Conole et al., 2004). However, through refinement of the major characteristics within each of these different models or theories, it is clear that there is potential for a better implementation to e-learning activities. For example, Table (2.1) provides a review of some of the existing models and theories and outlines their major characteristics, the types of approaches they most clearly support and how they could be actualized in regards to of e-learning

Due to the fact that e-learning practitioners are not academics in the field of education, the diverse array of 
theoretical applications and models that are available to them could seem foreign and overwhelming (McNaught \& Oliver, 2003). Previous research has shown that the use of toolkits can provide a means for non-specialists to understand and implement such learning theories in a method that encourages careful creation, productive product analysis, and proper application (Oliver et al., 2002). This table citation is taken from (Conole et al., 2004).

Summary of key learning theories and models, their characteristics, and how they might be realized in the context of e-learning (Conole et al., 2004) (See Table 2.1).

Table (2.1) shows several theories for learning. Some experts argue that these theories should serve as the basis for e-learning system development. Without a specific theory, these experts argue that the e-learning system does not have a solid foundation in educational theory. However, other experts argue that the educational theories can only serve the purpose of providing specific technological benefits rather than founding the entire elearning process. These experts argue that if a specific educational theory is used for the basis of e-learning that this method could become outdated with developing technology. Instead, these experts encourage a fluid implementation that focuses on using theories for specific benefits rather than for the entire process as a whole. 
Table 2.1 Theories and models for e-learning

\begin{tabular}{|c|c|c|c|}
\hline Theories & Main characteristics & $\begin{array}{c}\text { Potential e-learning } \\
\text { applications }\end{array}$ & Literature \\
\hline Behaviourism & $\begin{array}{l}\text { - Focuses on behaviour modification via } \\
\text { stimulus-response pairs } \\
\text { - Trial and error learning } \\
\text { - Learning through association and } \\
\text { reinforcement } \\
\text { - Pedagogical focus is on control and } \\
\text { adaptive response } \\
\text { - Focus on observable outcomes }\end{array}$ & $\begin{array}{l}\text { - Much of current e-learning } \\
\text { development represents little more } \\
\text { than transfer of didactic approaches } \\
\text { online, the 'web page turning } \\
\text { mentality' linked } \\
\text { directly to assessment an feedback }\end{array}$ & $\begin{array}{l}\text { Skinner } \\
\text { Tennant }\end{array}$ \\
\hline Cognitive & $\begin{array}{l}\text { - Focus on internal cognitive } \\
\text { structures; views learning as } \\
\text { transformations in these cognitive } \\
\text { structures } \\
\text { - Focus on human development } \\
\text { - Pedagogical focus is on the } \\
\text { processing and transmission } \\
\text { of information through } \\
\text { communication, explanation, } \\
\text { recombination, contrast, } \\
\text { inference and problem solving } \\
\text { - Useful for designing sequences } \\
\text { of conceptual material which build } \\
\text { on existing information structures }\end{array}$ & $\begin{array}{l}\text { - Salomon's notion of } \\
\text { distributed cognition } \\
\text { (Salomon, 1993) could lead to a } \\
\text { more shared knowledge } \\
\text { structure between individual } \\
\text { and surrounding informatio } \\
\text { rich environment of } \\
\text { resources and contacts } \\
\text { - Development of intelligent } \\
\text { and learning systems, and } \\
\text { the notion of developmental } \\
\text { personalized agents }\end{array}$ & $\begin{array}{l}\text { Anderson } \\
\text { Wenger } \\
\text { Hutchins } \\
\text { Piaget }\end{array}$ \\
\hline Constructivist & $\begin{array}{l}\text { - Focus on the processes by } \\
\text { which learners build their own } \\
\text { mental structures when } \\
\text { interacting with an environment } \\
\text { - Pedagogical focus is task-orientated } \\
\text { - Favour hands-on, self-directed } \\
\text { activities orientated towards } \\
\text { design and discovery } \\
\text { - Useful for structured learning } \\
\text { environments, such as simulated } \\
\text { worlds; construction of conceptual } \\
\text { structures through engagement in } \\
\text { self-directed tasks }\end{array}$ & $\begin{array}{l}\text { - The concept of toolkits and } \\
\text { other support systems which } \\
\text { guide and inform users } \\
\text { through a process of activities } \\
\text { could be used to good effect to } \\
\text { embed and enable constructivist } \\
\text { principles } \\
\text { - Access to resources and expertise } \\
\text { offers the potential to develop more } \\
\text { engaging and student-centered, } \\
\text { active and authentic learning } \\
\text { environments } \\
\text { - Micro worlds and simulations }\end{array}$ & $\begin{array}{l}\text { Papert Duffy \& } \\
\text { Jonassen }\end{array}$ \\
\hline Activity-based & $\begin{array}{l}\text { - Focus on the structures of } \\
\text { activities as historically } \\
\text { constituted entities } \\
\text { - Action through mediating } \\
\text { artefacts within a framework } \\
\text { of activity within a wider } \\
\text { socio-cultural context of } \\
\text { rules and community } \\
\text { - Pedagogical focus is on bridging the gap } \\
\text { between historical state of an } \\
\text { activity and the developmental stage } \\
\text { of a person with respect to that } \\
\text { activity e.g. current state of language } \\
\text { use and child's ability to speak a } \\
\text { language } \\
\text { - The Zone of Proximal Development - } \\
\text { the idea that assessing current ability } \\
\text { gives limited insight into an } \\
\text { individual's potential for development, } \\
\text { which is better studied through } \\
\text { examining their work alongside a } \\
\text { more able peer }\end{array}$ & $\begin{array}{l}\text { - In the last decade there has been } \\
\text { a shift from a focus on the } \\
\text { information (and in particular } \\
\text { content) aspects of ICT to an } \\
\text { emphasis on communication, } \\
\text { collaboration and understanding the } \\
\text { factors which underpin the } \\
\text { development of communities } \\
\text { - In particular there has been a } \\
\text { realization that the development of } \\
\text { content alone does not lead to more } \\
\text { effective learning, and that there is a } \\
\text { need to structure and foster learning } \\
\text { environments to enable } \\
\text { communities to develop } \\
\text { - Networking capabilities of the web } \\
\text { enable more diverse access to } \\
\text { different forms of expertise and the } \\
\text { potential for the development of } \\
\text { different types of communities }\end{array}$ & $\begin{array}{l}\text { Vygotsky, '34; } \\
\text { Wertsch, 85; } \\
\text { Engestrom, '87 }\end{array}$ \\
\hline
\end{tabular}




\section{Table 2.1 (continued)}

\begin{tabular}{|c|c|c|c|}
\hline Theories & Main characteristics & $\begin{array}{c}\text { Potential e-learning } \\
\text { applications }\end{array}$ & Literature \\
\hline $\begin{array}{l}\text { Socially situated } \\
\text { learning }\end{array}$ & $\begin{array}{l}\text { - Take social interactions into account } \\
\text { and learning as social participation } \\
\text { - Emphasis on interpersonal } \\
\text { relationships involving imitation } \\
\text { and modeling } \\
\text { - Language as a tool for learning } \\
\text { - and the joint construction of knowledge } \\
\text { - Language has two functions: } \\
\text { 1. As a communicative or } \\
\text { cultural tool, used for sharing and jointly } \\
\text { developing knowledge } \\
\text { 2. As a psychological tool for } \\
\text { organizing our individual thoughts, } \\
\text { for reasoning, planning, and } \\
\text { reviewing our actions } \\
\text { - Dialogue between tutor and student } \\
\text { can be articulated into } 12 \text { levels of } \\
\text { engagement - both external } \\
\text { and internal } \\
\text { - Knowledge is a matter of } \\
\text { competences with respect to valued } \\
\text { enterprise. Participating in the } \\
\text { pursuit of this, i.e. active engagement } \\
\text { - Meaning our ability to experience } \\
\text { the world and our engagement with } \\
\text { it as meaningful - is ultimately what } \\
\text { learning is to produce }\end{array}$ & $\begin{array}{l}\text { - Multiple forms asynchronous } \\
\text { and synchronous communication } \\
\text { offer the potential for more } \\
\text { diverse and richer forms of } \\
\text { dialogue and interaction between } \\
\text { students and tutors and amongst } \\
\text { peers, as well as } \\
\text { the use of archive materials and } \\
\text { resource for vicarious forms of } \\
\text { learning } \\
\text { - Different online communication } \\
\text { tools and learning environments } \\
\text { and social for a offer the potential } \\
\text { for new forms of } \\
\text { communities of practice or } \\
\text { facilities to support and } \\
\text { enhance existing communities }\end{array}$ & $\begin{array}{l}\text { Mercer Vygotsky } \\
\text { Laurillard Lave } \\
\text { Wenger }\end{array}$ \\
\hline Experiential & $\begin{array}{l}\text { - Experience as foundation for learning } \\
\text { - Learning as the transformation of } \\
\text { experience into knowledge, skill, attitudes, } \\
\text { values emotions } \\
\text { - Reflection as a means of transforming } \\
\text { experience } \\
\text { - Problem base learning a focus: } \\
\text {-Experience: Problem situation, } \\
\text { identification and definition } \\
\text {-Gather and reflecting on } \\
\text { information } \\
\text { - Theory formation and test in practice. } \\
\text {-Experience through Primary } \\
\text { and Secondary } \\
\text { - Reasoning and Reflection } \\
\text { - Evaluation (Dewey, 1916) }\end{array}$ & $\begin{array}{l}\text { - Asynchronous communication } \\
\text { offers new forms of discourse } \\
\text { which is not time-bound and } \\
\text { hence offers increased } \\
\text { opportunity for reflection } \\
\text { - Archive and multiple forms of } \\
\text { representation of different } \\
\text { communications } \\
\text { and experiences offer } \\
\text { opportunities for reflection }\end{array}$ & $\begin{array}{l}\text { Dewey } \\
\text { Kolb } \\
\text { Jarvis }\end{array}$ \\
\hline Systems theory & $\begin{array}{l}\text { - Focus on organizational learning, } \\
\text { or on modeling the development of } \\
\text { learners in response to feedback }\end{array}$ & $\begin{array}{l}\text { - New forms of distribution and } \\
\text { storage, archiving and retrieval } \\
\text { offer the potential for } \\
\text { development } \\
\text { of shared knowledge banks } \\
\text { across organisations and forms } \\
\text { of organisational distributed } \\
\text { cognition } \\
\text { - Models of learning account } \\
\text { adaptation in response to both } \\
\text { discursive and active feedback }\end{array}$ & Senge;Laurillard \\
\hline
\end{tabular}


Perhaps one of the most influential theories of learning for generating and testing a general theory of attitude-behavior connections is the theory of reasoned action (Choi et al., 2007). The theory assumes that individuals behave according to their conscious intentions, which are based on rational estimations of the possible results of the specific behavior. This theory is based on the idea that the belief of an individual is his subjective probability of the possible consequences for a given behavior. This belief of the individual influences his attitude, which shapes his behavioral intentions (Ajzen \& Fishbein, 1980). This psychological information is included for future research, and this study does not focus on psychological influences on behavior as mentioned in the limitations section. However, in an e-learning environment, the attitude could be based on a general attitude towards e-learning in both a general and specific context.

\section{Diffusion of Innovation}

One of the most important methods for evaluating the adoption and use of new technology has been created through the use of diffusion research. In 1903 Gabriel Tarde created the S-shaped curve that is still the most important 
method for analyzing the acceptance rate of new technological innovations. Rogers (1986) point out that:

"Tarde observed that the rate of adoption of a new idea usually In regards to: time: at first, only a few individuals adopt a new idea, then the rate of adoption spurts as a large number of individuals accept the innovation, and, finally, the adoption slackens as only a few individuals are left to adopt". (pp. 71-73)

This analysis is important for understanding the rate of acceptance for e-learning in institutions of higher education. This method of analysis focuses on aspects that influence everyone involved with the e-learning process, including students, instructors, administrators, and government officials. One of the leading theorists for diffusion research Rogers (1983a) identifies four major aspects in the diffusion process. Rogers defines diffusion as "the process by which an innovation is communicated through certain channels over time among the members of a social system." (1983, p.10). This definition contains four major aspects that can be used to evaluate the process of innovation diffusion: innovation, communication channels, time, and social system.

Innovation is described "as an idea, practice, or object that is perceived as new by an individual" (Rogers, 
1985). Rogers identifies five characteristics that are significantly correlated with the rate of adoption for innovations: relative advantage, compatibility, complexity, trial time, and observability. Rogers (1983b) notes that relative advantage is a good indicator of the rate of adoption for innovations in most cases. This category includes costs, investment returns, efficiency, and yield. Compatibility, the second characteristic, is the extent to which the needs as identified by the adopter are met by the specific innovation. The third characteristic, complexity, is considered to have a negative correlation with the rate of adoption. If the innovation is found to be too difficult to understand or use for the potential adopter, this innovation is less likely to be adopted. Trial time is the fourth characteristic and is the opposite of complexity because it allows the individual time to have a phased-in approach where they can experiment with and developing understanding for the innovation. The last innovation characteristic, observability, reveals that innovations which produce tangible results are more likely to be adopted.

The second aspect for evaluation the process of innovation diffusion is the communication channels that exist and develop. Communication channels develop with 
diffusion to provide a method for transferring information about the innovation between individuals. Rogers (1986) identifies two types of communication channels: mass media and interpersonal channels. The two channels differ in their methods of information transmission. Mass media uses distribution methods that might reach a larger audience. Interpersonal communication channels form between two individuals sharing information and includes individuals who are either homophilous, having similar values in certain characteristics (such as educational level or social status), or heterophilous, having different values in these characteristics. Rogers indicates that two homophilous individuals are more likely to have greater effects on the transmission of knowledge, formation of attitudes, and behavioral changes related to a new innovation due to the fact that they share similar values relating to their work and home environments. Heterophilous individuals, in contrast, have a greater potential for creating problems in the diffusion of innovations than their homophilous counterparts because their communication style may create intellectual dissonance based on the differences in their backgrounds and values.

Time is the third aspect in Roger's analysis of diffusion and includes three different measurements: the 
innovation-decision process that allows an individual encountering new knowledge to either adopt it or reject it, the innovativeness of an adoption that is defined by the date when the decision for adoption occurs, and the number of people that adopt the intended innovation.

The last aspect for the diffusion of an innovation as defined by Rogers is the social system. Rogers (1995) identifies three ways that innovation decisions occur within a given social system: optionally, collectively, and through authority. Optional decisions are made by individuals without external influence. Collective decisions are based on the consensus of the given group. Finally, Decisions made through authority are created by individuals with technical expertise or power within the given group.

\section{Motivation and Benefits of E-learning}

The growing importance of e-learning technology has caused a perspective that views the implementation of e-learning in institutions of higher education as beneficial. On the other hand, implementing e-learning is failing in many situations because there is a lack of sufficient planning, policies, and strategies to manage this integration (Flowers, 2004). This lack of proper 
policies and strategies causes the quality, learning experience, and benefits of the students, instructors, and institutions to suffer.

If the policies of the institution are appropriate and well received, then an environment of success can develop. This environment can foster a more successful integration, instruction, and evolution towards e-learning technologies (Broadbent, 2000).

To encourage institutions of higher education to transition into e-learning, significant benefits must be provided by the new technology (Simmons, 2002). Benefits can exist for both students and instructors. For example, tutoring can occur at anytime from any location. Also, materials that exist online can be updated and viewed in real time: students can see modifications as soon as the instructor makes them. When the online materials are created properly, online learning systems can be used to evaluate students' needs and current expertise level as well as to assign proper materials for students to incorporate to attain the intended e-learning results.

Academic programs that are delivered with e-learning also provide many benefits for instructors, students, and academic administrators. The interaction between instructor and student increases in an online environment as well as 
the ability to communicate with a larger number of students, creating an increase in globalization and diversification(National Education Association, 2000). Another potential benefit that exists is the fact that the needs of non-traditional students, who often maintain responsibilities like careers and families which prevent them from enrolling in traditional college courses during the daytime, can be used arrange their e-learning time around their existing schedules. Also, there are other students who may simply prefer learning in an e-learning environment. Moreover, as financial support from the state decreases in public higher education institutions, elearning allows a new audience of pupils as well as a new source of revenue for the institution without additional requirement of traditional on-campus facilities like classroom space and hall buildings.

\title{
Previous Studies
}

\author{
Several studies have examined the factors that \\ influence instructors to participate in and use e-learning \\ technologies in their delivery of instruction. Perhaps the \\ most important of these studies for the purpose of this \\ current research are (Meyers, 2000a), study of the factors
}


that motivate and impede instructors in the use of computers .

Meyers' study focuses on the personal needs of individuals that can motivate computer use, significant differences between the instructors' years of experience ("new", "experienced", and "senior") and the factors that could motivate computer use, and significant differences that could exist between these instructors with differing experience and their personal needs that motivate them to use a computer. The study uses descriptive and ex post facto research designs to analyze that data of two hundred forty-eight participants (a 66 percent return rate for the given questionnaire) .

This study has six major findings that show the correlation between motivations and barriers to computer use. The first finding indicates that when "a computer is located in the classroom" the instructor is motivated to use this computer. This finding relates to the belief that accessibility can be an important motivator for encouraging the adoption of technology. "Release time" is the second finding that is also mentioned as a motivator for computer use and relates to the aspect of trial time in Roger's theory of innovation diffusion. Correspondingly, "lack of time" is also mentioned as a barrier that impeded computer 
use. The third finding, seen in 99 percent of 244 respondents, shows that the ability to use a computer is an essential skill for the twenty-first century. This finding relates to the relative advantage of the innovation in Roger's theory of innovation diffusion. The fourth finding is based on Maslow's Hierarchy of Needs Theory and indicates that instructors were motivated by higher order needs of belonging, esteem, and self-actualization. The fifth finding shows that "senior" instructors with over 15 years of experience were significantly higher in agreement that they are able to receive help with computer technology when they needed it than the "new" instructors with one to eight years of teaching experience. The final finding shows that the "new" instructors were more motivated to share their computer expertise with others and enjoyed recognition for using computers. The motivations and barriers shown in this study relate specifically to computer use, but these same motivations and barriers may be significant for the adoption of all new e-learning technologies.

Another study that shows the effect of motivations and barriers on e-learning application, is the study that Betts (1998) conducted on the factors that motivate instructors' participation in e-learning. This study focuses on the 
intrinsic motivators, extrinsic motivators, and barriers for instructors of e-learning courses, instructors of faceto-face courses, and academic administrators. The study aimed at identifying factors that could motivate instructors of e-learning as well as face-to-face courses to teach e-learning courses. The study also focused on potential factors that served as barriers and impeded each group's participation in e-learning as well as significant differences in viewpoints that existed between course instructors and academic administrators, deans in particular. Betts's study reveals that the primary motivators as indicated by the participants' already using e-learning were intrinsic and mainly focused on attaining self fulfilment. In addition, Betts states that intrinsic factors created positive influence for instructors in Distance Education, but extrinsic factors showed no significant influence.

Meyers (2000) dissertation also shows that there are factors, such as motivations and barriers, which affect the instructors' implementation of technology in the classroom, specifically computers. Meyers found that instructors have been somewhat unwilling to incorporate computers into the classroom, but this reluctance to adopt computer technology could be the result of insufficient motivation and support 
for the instructors to make this transition. This study only focuses on the specific use of computer technology, but the implications that are established by this study could be significant for understanding the intrinsic and extrinsic factors that influence the adoption and integration of any e-learning technology.

Another study by Maguire (2005) compares the findings of previous researchers in e-learning technology in terms of many factors, including intrinsic and extrinsic barriers and motivations. The intrinsic barriers included competition from private and public institutions, career and job security concerns, intimidation by technology, lack of understanding of Distance Education and what will work at a distance, and resistance to innovation. The extrinsic barriers for the instructor are included as institutional barriers and include concerns about faculty workload; lack of administrative support; lack of collegial support; security concerns; lack of grants for materials, expenses, design \& development; lack of knowledge of where to go for assistance; lack of merit pay or monetary support; lack of release time; lack of technical support; lack of systems reliability; lack of training; developing effective technology skills; difficulty in recruiting faculty; inadequate hardware and software; inadequate 
infrastructure; slow action on critical issues; weak communication; time taken away from research; and lack of time to develop and maintain course material. The intrinsic motivations include optimal working conditions, overall job satisfaction, personal motivation to use technology, selfgratification, intellectual challenge, and desire to get students more involved with technology. The extrinsic motivations include role modeling and peer observation as well as collegial support and recognition. The extrinsic motivations for the instructors also include institutional factors such as administrative encouragement and support, credit towards tenure and promotion, recognition of work, training in how to effectively teach online, increase in salary, and instructional design and development support. This study shows the findings of previous studies on elearning adoption and integration in terms of these intrinsic and extrinsic motivations and barriers. Likewise, the current study will also try to examine intrinsic and extrinsic motivations and barriers.

Some of the barriers to e-learning have been solved through technological evolutions and increased budgets for this technology, but other barriers are still dependent on the instructors themselves. Choi et al.(2007) note that" Whilst the importance of end-user training is recognized as 
a factor in the success of information systems, companies have suffered from relatively low information system training budgets and an insufficient number of trainers. However, technological innovations in computers, telecommunications and the Internet, e-learning have made it possible to overcome many constraints". (pp.223-243)

This analysis shows that while the budget and instructors may be insufficient, the development of technology has made it possible to bypass these situations and still be able to focus on the information systems. There are many important factors that determine the success of implementing technology in education. Instructors are one of these factors. Webster \& Hackley (1997) identify that three instructor characteristics exist which strongly affect the outcomes of the learning: teaching style, control of technology, and attitude towards technology. Collis (1995) indicates that the instructor plays a crucial role in effecting success for the learners through the effectiveness of the e-learning delivery. For Collis, the instructor's ability to implement technology, rather than the technology itself, determines the significance of the learning. In addition, Webster and Hackley support the notion that students will have a more positive learning experience if instructed by an instructor with a positive 
attitude towards technology and e-learning techniques: a perspective consistent with (Fulk et al., 1990) social influence model of technology. Moreover, Fulk (1993) notes that supervisor, co-worker and work group are examples of social influence that affect either positively or negatively the attitudes toward technology in this mode. Social constructivist theories maintain that members of an organization are working on developing coordinated patterns of behavior with one another based on personal observations of the behaviors of other members, the consequences of observed behaviors, and emotional reactions of the members. Fulk's research (1993) on the social influence model has also stated that user's attitudes toward e-mail are influenced by colleagues and managers in place work. Moreover, there are numerous factors which act as barriers and explain the differences among instructors' attitudes toward the implementation of technology: frustration with technical problems, frustration with physical limitations such as those placed on the instructor by digital web cameras during instruction, lack of preparation to teach with the technology, and a lack of motivations for implementing e-learning .

A study of instructors and their use of e-learning in Hong Kong by So \& Swatman (2006) have also indicated that 
gender may provide an important factor for influencing instructor motivation and use of e-learning technology. This study used a pilot survey to assess the preparedness of Hong Kong instructors for e-learning. Significant differences in preparedness were observed between male and female instructors. Differences observed between genders can be controversial, and some researchers have not observed any differences between male and female instructors. However, this study shows a significant difference in the responses of the male and female instructors in regards to their confidence despite the fact that both groups received equal training with males showing more positive responses. Additional differences were observed in regards to team/group work cultures, and females responded more positively to this type of work environment. The results of this study appear to indicate that the construction of professional e-learning development for instructors should consider gender and include the particular requirements of female instructors in this implementation.

Another study by Qing (2006) in Canada also indicates these same differences between the genders and further investigates the increased confidence of male instructors. This study also shows the female preference for team/group 
work culture and supports the notion that e-learning incorporation should include this type of environment to foster acceptance of the technology by female instructors. As far as male confidence is concerned, this study shows a significant difference in the responses between the genders in relation to the enjoyment of e-learning technology. Perhaps this enjoyment creates an intrinsic motivation that encourages the confidence of the male instructors. While the results of these studies should not be ignored, other studies have not shown any significant differences between genders in relation to e-learning technology.

For example, a study by Koohang (2004) at the University of Wisconsin-Milwaukee examined the perceptions of users of e-learning technology. This study compared the results based on many factors including gender. The study found that there was no significant difference in the results based on gender. This finding is contrary to the previous two studies that focused on the importance of this gender difference. Thus, it is not conclusive whether there is a significant difference between genders in regards to e-learning technology, but this potential factor should not be ignored in an analysis of the results.

The cultural background of the studies may also influence the results. The fact that this research is being 
conducted in Saudi Arabia could perhaps have a significant influence on the results based on gender. However, this result is yet to be determined.

Expertise could also be an influential factor in the adoption and use of e-learning technology. Lane \& Yamashiro (2006) conducted a survey to evaluate the influence of various variables, including expertise, on e-learning incorporation. The study examined both general expertise and specific expertise in certain areas of technology in terms of beginner, intermediate, advanced, and expert ratings. The researchers found that these factors could be important for the adoption and use of e-learning technology. In addition, the researchers compared these findings against other variables, including gender, and concluded that gender may influence perceived level of expertise. Due to the significance of these findings, expertise is being used as a variable for the purposes of this study in order to understand how instructors' perceptions of themselves and their abilities could influence their adoption and use of e-learning technology.

\section{The Challenges and Barriers of E-Learning}

The development of digital technologies in education has changed the academic experience for both instructors 
and students. Both groups have had to adapt with the evolution of the institutional support process. The preparation for a course in light of digital technology development may require the students and instructors to learn a new software application that can deliver a concept more effectively than previous methods. The students may reveal their learning efforts through text, audio, or video for instructor evaluation. Furthermore, instructors and institutions are then faced with a wide range of challenges and needs as they engage in e-learning (Levine \& Sun, 2002); Arabasz et al., 2003).

\section{Institutional challenges and barriers:}

Higher education faces several challenges and barriers in the area of e-learning. In addition, Information and Communications Technologies allow higher educational institutions to have a potentially wider audience than before. However, in addition to the promised benefits of elearning and technological development, there are still significant barriers remaining both inside and outside the higher educational institutions. Levine \& Sun (2002) identify a number of barriers that must be dealt with in order to efficiently incorporate e-learning programs and 
divide these barriers into two categories: internal and external.

The internal barriers consist of pedagogical challenges, funding difficulties, and the slow pace of implementation of changes in governance. One of the most significant barriers facing institutions of higher education is the lack of professional development for faculty members. Most institutions of higher education do not educate graduate students on teaching styles or methods, and most do not require the instructors to possess teaching licenses. Previously, instructors have developed their teaching styles based on their own experience as students. This development has focused on face-to-face lectures, which are traditionally the most prevalent method of instruction in higher education. However, in order to achieve significant results in e-learning programs, instructors should understand that alternative methods of teaching may be more appropriate for this kind of technology driven learning. Levine \& Sun (2002) insist that instructors have to change their teaching styles to focus on coaching, discussions, and more opportunities for student-instructor interaction.

This focal shift in pedagogy to "anytime, any place learning" brings up instructors' concerns about their new 
role in the learning process as well as their new, increased workload. This new, increased workload can be seen in the creation of courses, maintenance of chat rooms, and response time to emails from students. All of these increased elements of the instructors' workload require more time and energy from the instructor than traditional courses (Levine \& Sun, 2002). Time is considered an administrative issue due to the institution's ability to allow release time for the instructors to develop and maintain e-learning courses. Lack of release time would also be a barrier for instructor participation in elearning (Betts, 1998). In addition, instructors sometimes feel as if the time used on course development by itself takes time that could be spent on research (Rockwell et al., 1999) . Furthermore, the lack of recognition for elearning instructors is an additional barrier that can exist from the institution. The time that an instructor devotes to teaching or developing e-learning courses is not as highly valued by some institutions as the time being spent on research or even teaching traditional face-to-face classroom courses (Maguire, 2005).

Another internal challenge confronting institutions of higher education is availability of funding. Due to financial problems, institutions are continually struggling 
to find sufficient resources to fund stipends, provide release time, purchase and maintain equipment, and hire support staff (Levine \& Sun, 2002). The lack of technical support is a significant barrier created by the administration of the institution(Berge, 1998). This lack of technical support consists of the lack of system reliability and access to e-learning course software as well as the insufficient infrastructure, hardware, and software technology.

The final internal challenge is the slow implementation of governance and policy issues through traditional channels that cannot evolve quickly enough to meet the needs of e-learning programs. This lack of modern governance methods results in the rise of private competitors which provide e-learning programs, such as the University of Phoenix, DeVry Institutes, and Capella University. The private competitors influence the development of e-learning programs and, in effect, take control of the current curriculum away from the traditional institutions of higher education.

External barriers to e-learning implementation are also significant. Debates exist between instructors and institutional administrators on whether the scholarly works of instructors belong to the individuals themselves or to 
the institutions in which they work. Many instructors argue that e-learning course materials should be their own personal property. These instructors rely on the academy's traditional practice of allowing professors to retain personal rights to the materials that they develop. However, some institutions counter this argument by claiming that the institution itself provides the time, money, and resources that are used in e-learning. Thus, the institutions consider the e-learning product to be a "work made for hire" and, therefore, the property of the institutions. Moreover, e-learning programs have raised concerns about the proper use of online materials that are copyrighted. In order to deal with these multiple external barriers, instructors and institutions need to maintain mutually acceptable policies and procedures that allow for the institution's use of materials and, at the same time, motivate instructors to become personally involved in the e-learning process.

\section{Instructor challenges:}

Some experts examine the motivational factors that influence the use of e-learning technology. Maguire (2005) examines the fact that, in addition to the personal factors that can encourage an instructor's use e-learning, barriers 
also exist that can deter the instructor from teaching through e-learning. These barriers are less frequent than positively motivating factors because they are more extrinsically based than intrinsically based. There are some intrinsically based barriers that do impede an instructor's use of e-learning technology such as resistance to changes and intimidation from technology (Parisot, 1997; Berge, 1998). In addition, Berge (1998) explains the barrier that exists with resistance to changes: many instructors indicated a reluctance or inability to handle the changes created by online teaching. These reluctant instructors usually have not incorporated much technology into their traditional face-to-face classroom courses, and some have even found ways to avoid using email. Thus, for these instructors, the idea of instructing an entire course in an e-learning environment is an intimidating consideration.

One intimidation from technology that could impede an instructor's use of e-learning regards their understanding of e-learning and what types of courses are most appropriate for this forum (Berge, 1998). Instructors are also concerned with the fact that they are dependent on developers and programmers, and many are concerned about security issues (Maguire, 2005). Other instructors feel 
personally intimidated by the increasing technology, and these instructors are concerned that e-learning courses and programs will take the place of the traditional on-campus learning experience (Maguire, 2005). These instructors worry about their own job security based on the technological evolutions occurring in their field (Dooley \& Murphrey, 2000). In addition, some instructors are concerned that "capturing their intellectual property through multimedia might eliminate positions" (Dooley \& Murphrey, 2000) .

Another barrier for the instructor that is based on intimidation is the fear of competition. Some instructors are intimidated by the thought that e-learning creates a virtual classroom and allows students to take courses from one or more institutions. Thus, students will select courses at institutions that will provide them with the education that they desire to meet their needs. Some instructors from traditional institutions of higher education fear the increased competition from other elearning courses and programs (Dooley \& Murphrey, 2000).

The amount of time that is required to develop and maintain e-learning courses compared to traditional courses represents a significant barrier for instructors (Arabasz et al., 2003). In e-learning environments, the instructors 
should have sufficient time to reanalyze, reformat, and redesign the course to adapt it for e-learning delivery; attend technical and pedagogical instruction; and communicate with and offer feedback to students in their teaching (Arabasz et al., 2003).

Technicality is another challenge facing e-learning instructors. Instructors need to not only prepare the class itself but also develop contingency plans in the event of technical problems in the future (Arabasz et al., 2003). Furthermore, the instructor should bear the students' technical limitations, such as hardware and software of computer, bandwidth, and networks, in mind when developing the course. Thus, when instructors are designing an elearning activity, they could include multimedia elements or complex web pages in the course material, but the students may not know how to use these elements effectively or be able to use them at all (Arabasz et al., 2003).

One of the barriers to the implementation of elearning is the lack of instructor interest in adopting the new technology. Not every instructor is willing to adopt elearning, or other related technologies, into their teaching style (Arabasz et al., 2003). The fundamental personal beliefs about education that instructors bring to the educational process determine how they evaluate the use 
of technology and e-learning strategies (Cuban, 1986). Not all experts agree that the inclusion of new information and communication technologies is panacea and positive within educational environments and organization. Postman (1995) cautions against the many dangers he sees in placing too much confidence in the "god of technology" (p. 47). Postman (1995) states that new technology can be helpful for teaching facts, but it is against the development of social values. He indicates that many of the problems in the current and future school systems cannot be solved simply by using new hardware technology (Postman, 1995).

\section{Summary}

In conclusion, technology presents new and developing challenges for all levels of education from instructor to student to administrator to government representative. Much of the existing literature has examined the relationship between intrinsic and extrinsic motivations and barriers that influence the use of technology for educational purposes. This research has shown strong connections between motivation, particularly intrinsic, for encouraging instructors to implement technology in their courses and classrooms. In addition, the research has shown the 


negative impact of challenges and barriers to the
implementation of technology.
The implementation of e-learning technology is crucial
for modern institutes of higher education because of the
growing importance and development of technology in
general; however, the problems and benefits that are
associated with implementing this developing technology
should be closely examined in order to understand the exact
nature of this technological evolution for the purposes of
education. This study will focus on the relationship
between different types of positive and negative
motivations, both intrinsic and extrinsic, as well as other
challenges that affect the use of e-learning in a saudi
Arabia institution of higher education.




\section{CHAPTER (III)}

\section{Methodology}

This chapter focused on the research methods utilized in the study. It addressed the research questions, instrument development procedures, research procedures, a description of the study sample, a discussion of the instrumentation employed to answer the research questions, the pilot study, and the description of the data analysis.

\section{Research Questions}

The purpose of the quantitative study was to determine whether significant differences exist among instructors from King Abdulaziz University's (KAU) Humanities and Scientific Colleges concerning their use of e-learning technologies as measured by a survey questionnaire. Specifically, the study addressed the following research questions:

\section{The first set of questions:}

1- What are instructors' perceived levels of technology expertise?

2- What is the current use of e-learning by the instructors of the King Abdulaziz University? 
3- What are the intrinsic and extrinsic factors that motivate the instructors to use e-learning in their teaching?

4- What are the intrinsic and extrinsic factors that impede the instructors to use of e-learning in their teaching?

\section{The second set of questions:}

1- Is there a significant difference in the perceived technology expertise of instructors based on main effect (A) sex, (B) academic field, (C) teaching experience, and Interaction ( $A B, A C, B C, A B C)$ ?

2- Is there a significant difference in the use of elearning among instructors based on main effect (A) sex, (B) academic field, (C) teaching experience, and Interaction $(\mathrm{AB}, \mathrm{AC}, \mathrm{BC}, \mathrm{ABC})$ ?

3- Is there a significant difference in motivational factors among instructors based on main effect (A) sex, (B) academic field, (C) teaching experience, and Interaction $(\mathrm{AB}, \mathrm{AC}, \mathrm{BC}, \mathrm{ABC})$ ?

4- Is there a significant difference in barrier factors among instructors based on main effect (A) 
sex, (B) academic field, (C) teaching experience, and Interaction $(A B, A C, B C, A B C)$ ?

These questions establish the variables that are to be used in this study. There are three independent (sex, academic field, and years of teaching experience) and four dependent variables (motivations, barriers, current use, and expertise). The following illustrations (Fig 3.1 \& Fig 3.2) demonstrate the relationships among each of the four dependent variables with the three independent variables.

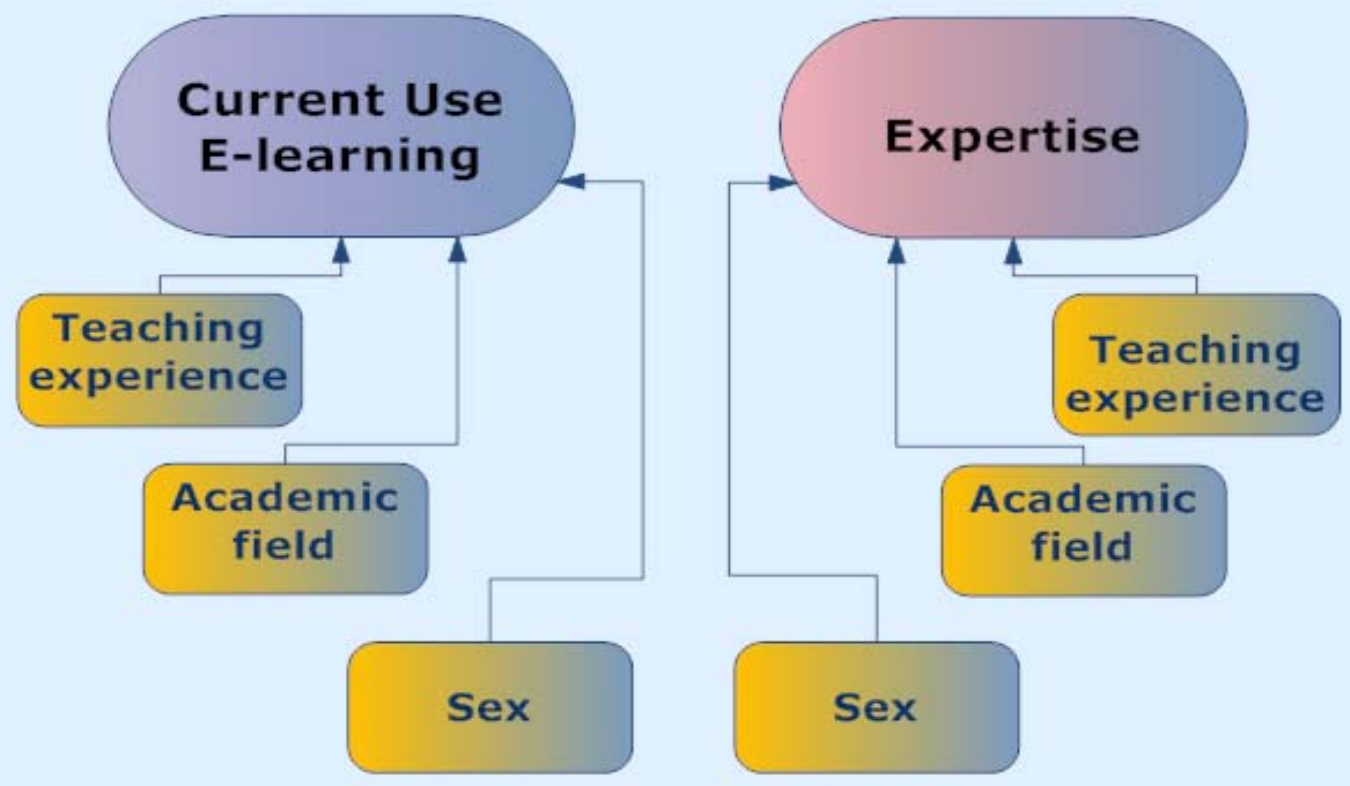

Fig 3.1: Tow dependent variables with three independent variables 

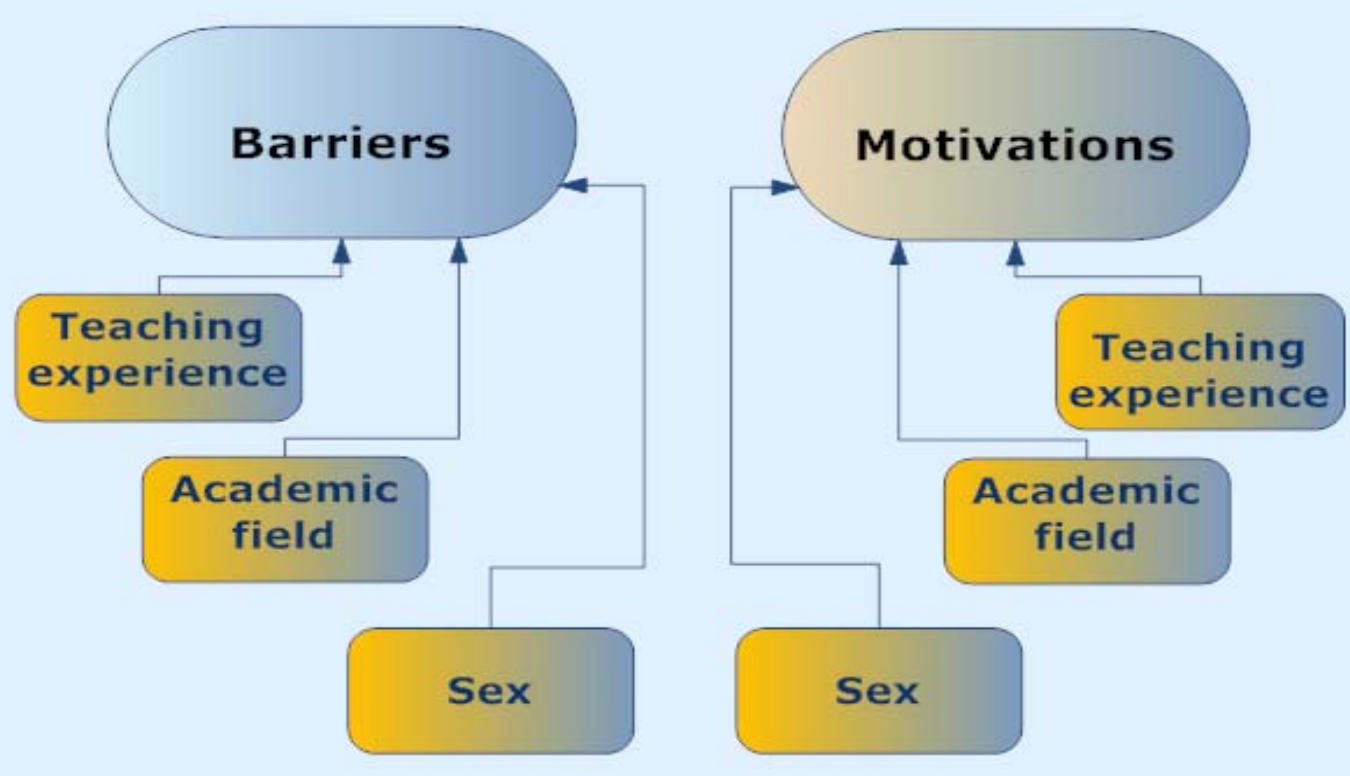

Fig 3.2: Tow dependent variables with three independent variables

\section{Hypotheses of the study}

The following null hypotheses, based on the second set of the questions, were examined. They are:

Ho1: There is no significant difference in the technology expertise of instructors based on main effect (A) sex, (B) academic field, (C) teaching experience, and Interaction $(A B, A C, B C, A B C)$.

Ho2: There is no significant difference in the use of elearning by instructors based on main effect (A) sex, 
academic field, (C) teaching experience, and Interaction $(A B, A C, B C, A B C)$.

Ho3: There is no significant difference in motivational factors among instructors based on main effect (A) sex, (B) academic field, (C) teaching experience, and Interaction $(A B, A C, B C, A B C)$.

Ho4: There is no significant difference in barrier factors among instructors based on main effect (A) sex, academic field, (C) teaching experience, and Interaction $(A B, A C, B C, A B C)$.

\section{The population}

The population of the study consisted roughly of 2000 instructors of the King Abdulaziz University (KAU) in Saudi Arabia, during the academic year 2007-2008. These included both the separate men's and women's sections at the one campus in Jeddah. KAU is one of the largest and official universities in Saudi Arabia, and it has a wide range of academic areas. It was chosen as the site of the study because it is involved in implementing e-learning techniques. Also, as it has larger size, several studies of organizations and innovation adoption have operationalized size in such terms as the number of employees and the size of the population served. Findings, therefore, differ 
partly due to definitions. Rogers (1995) saw size as a probable surrogate measure of other dimensions leading to innovation, among them total resources, technical expertise of employees, and organizational structure (p. 379). He further suggested, as most researchers have consistently found, that larger organizations are more innovative. Brace \& Roberts (1996) found similar results to Rogers. They indicate that a larger institution is more willing to incorporate modern technology. They also indicate that physical resource support is essential for the spread and acceptance of this technology. These larger institutions usually have a larger physical resource support and are able to incorporate this new technology more readily.

\section{Selection of the Sample}

The sample was selected at random from instructors in the male and female sections of the humanities and science colleges at KAU. The research was conducted with cluster sampling in order to have a proper selection that represented the instructors in the two academic fields. These two fields have been chosen in order to hopefully provide an appropriate sample size to represent instructors at KAU . 


\section{Instrumentation}

Development of Instrumentation for this study relied on structured instruments (see Appendix A for English version and Appendix B for the Arabic version) that consist of three parts (see Figure 3.3). These instruments were developed for this study to investigate the factors that may influence instructors' use of e-learning technologies in their teaching. These instruments were based on a review of literature in the field, particularly Ishtaiwa (2006) and Medlin (2001) .

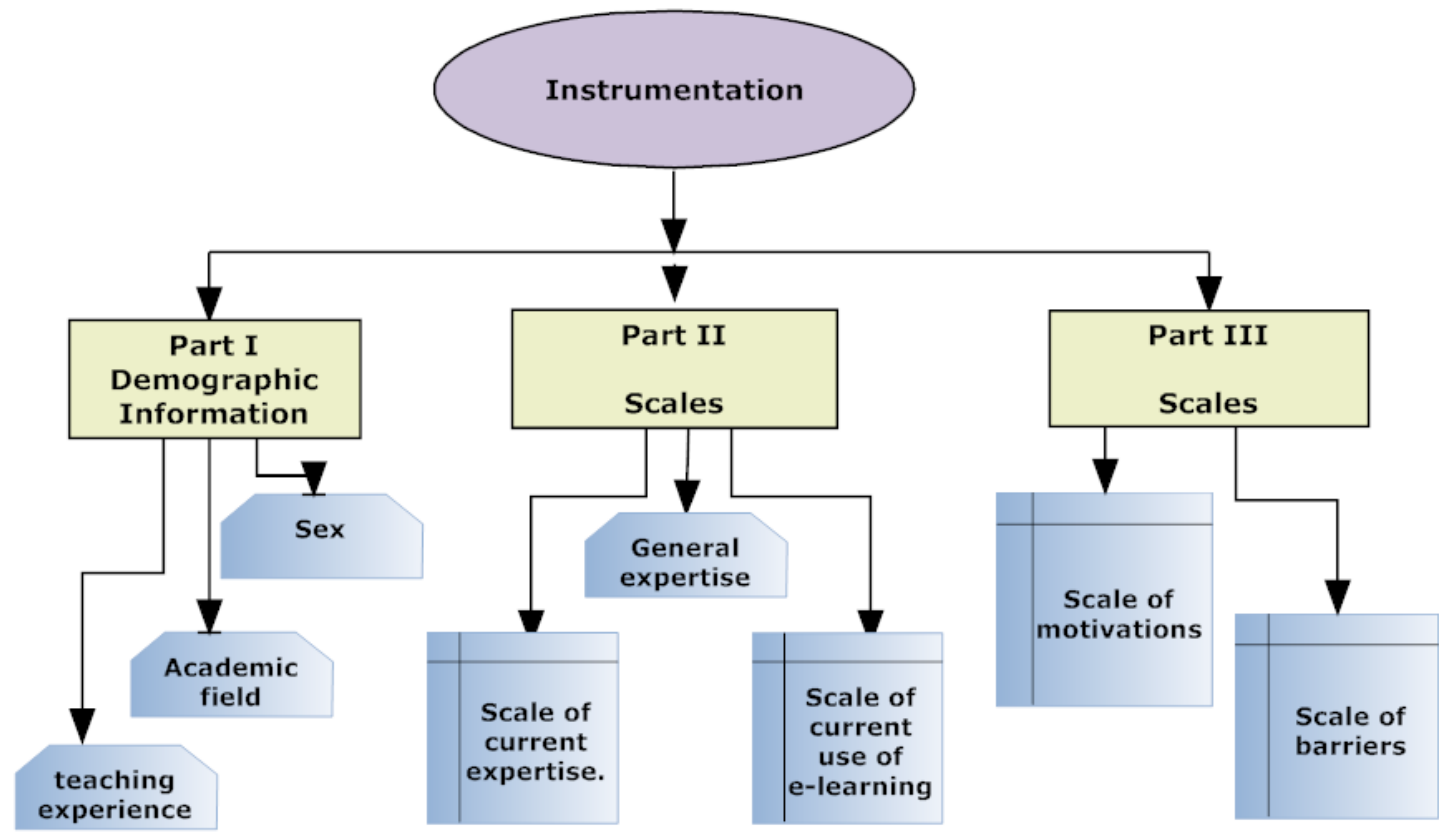

Figure 3.3: Instrumentation of the Study 
The survey questionnaire consists of three major parts: (1) demographic information, (2) individual elearning knowledge (expertise) and use, and (3) intrinsic and extrinsic factors that influence the use of e-learning techniques.

The first part includes demographic information. The demographic information consists of three items that seek individual personal information of the participants and is divided into these variables: sex, academic field, and years of teaching experience.

The second part includes two scales designed by the researcher based on a review of the literature, in particular Ishtaiwa's (2006) study on the Factors Influencing Faculty Participation in E-Learning and Medlin (2001) study on the factors that may influence a faculty member's decision to adopt electronic technologies in instruction, for measuring instructors' general and specific expertise and current use of e-learning. The first scale consists of 12 items regarding expertise. These include using a word processor to create documents, using a spreadsheet to create charts and graphs, using a computer to find resources from the university library, searching the web to find information and resources, using database software to set up and access information, using 
presentation software (e.g., PowerPoint), using graphic software to create illustrations, slides, or images, using audio/video clips software to create or enhance presentations, website design, using a computer to communicate with others, using of electronic bulletin board, and using video conferencing.

The instrument employed a Likert-like scale to elicit participants' responses related to their current expertise with each type of e-learning technologies. A five point Likert-like scale was used: Don't use $=0$, Novice $=1$, Intermediate $=2$, Proficient $=3$, Expert $=4$.

The second scale consists of 15 items regarding current use of e-learning as the frequency of the types of technology used. This scale was partially based on Ishtaiwa's (2006) study and Medlin's (2001) study. It includes use of computer software for handouts or lecture notes, used email as the primary source of student contact outside the classroom, holding virtual office hours, created and used an on-line syllabus with hyperlinks to class resources, use on-line bulletin board, used personally designed Web-based lectures, notes, or tutorials, used personally designed web-based tests or quizzes, provided web-based grades, used Internet research and searches, posting required readings on course web page, 
use on-line chat room, commenting on course work electronically, electronics conferencing, use video tapes for instruction, and use audio tapes for instruction.

The instrument employed a Likert-like scale to obtain participants' responses related to questions describing the frequency and type of e-learning technologies used. A five point Likert-like scale was used: 0 =Never (0\%), 1=Seldom $(1-25 \%), \quad 2=$ occasionally $(26-50 \%), \quad 3=$ often $(51-75 \%), 4=$ Almost all the time (76-100\%).

Finally, the third part includes two scales for measuring intrinsic and extrinsic factors that influence instructors' use of e-learning. The first scale consists of 23 items to examine which factors motivate instructors to use e-learning in their teaching. It includes requirement by department or university, administrative encouragement and support, technical support in solving computer problems, support and encouragement from peers, access to software tools for enhancing teaching with technology, credit toward promotion and tenure, professional prestige and status, training programs and support, reduced teaching load, opportunity to improve teaching, rewards/recognition for innovation in teaching, time available to learn/pursue the integration of e-learning technologies, increase in salary, opportunity to reach new audience that can not 
attend classes on campus, opportunity for scholarly pursuit, funding for materials/expenses, classroom technology infrastructure (e.g., wiring, computers, or projectors), resources about how to apply technology in teaching, student' access to resources, student' computer skills, my computer skills, my colleagues' computer skills, and opportunity to enhance communication with others.

The instrument employed a Likert-like scales to obtain participants' responses related to questions describing the factors that motivate one to use e-learning technologies in instruction. A five point Likert-like scale was used: Highly Discouraging $(H D)=0$, Discouraging $(D)=1$, Not a Factor $(\mathrm{NF})=2$, Encouraging $(\mathrm{E})=3$, Highly Encouraging $(\mathrm{HE})=4$.

The second scale consists of 18 items which examine factors inhibiting instructors' use of e-learning in their teaching. It includes lack of interest, lack of time to learn a new technology and contacting students via email, negative comments made by colleagues about e-learning technologies, lack of support and encouragement from administrative, lack of support and encouragement from peers, lack of instructors' technological knowledge, lack of students' technological knowledge, lack of training programs, lack of face-to-face interaction in e-learning 
courses, lack of credit toward promotion and tenure, lack of funding for materials/expenses, lack of rewards/recognition for innovation in teaching, concern about course quality, lack of technical support in solving computer problems, lack of technological infrastructure, lack of Student' access to resources, lack of resources about how to apply technology in teaching, and security concerns.

The instrument employed a Likert-like scale to obtain participants' responses related to questions describing the factors that impede use e-learning technologies in instruction. A five point Likert-like scale was used: $0=$ No barriers (NB), 1 = Very few barriers (VFB), 2 = Few barriers (FB), $3=$ some barriers (SB), $4=$ Many barriers $(\mathrm{MB})$.

\title{
Validity and Reliability of the Instrument
}

\author{
Validity refers to the "defensibility of the \\ inferences researchers make from the data collected through \\ the use of an instrument" and reliability of an instrument \\ is "one that gives consistent results" (Fraenkel \& Wallen, \\ $2000)$.
}

The survey questionnaire was validated in two stages. In stage one, the questionnaire was submitted to a panel of 
experts in the Department of Curriculum and Instruction, Research Center, and Educational Technology at West Virginia University (WVU). Experts were asked to judge the items for their adequacy to measure the level of the current use of e-learning technologies by instructors in their teaching, level of current expertise, and factors that influence instructors use of e-learning.

The panel of experts also was asked to assess (1) the clarity in the directions and the question, (2) the appropriateness of the variables that corresponded with the Likert-like scale, (3) the continuity across sections, the amount of time needed to complete the questionnaire, and (5) to recommend additions or deletions of items and variables to the questionnaire. These requests were informed by suggestions made by Betts (1998) about designing and validating survey instruments.

Based on the first stage of validation, and comments and suggestions from the panel of experts at WVU, minor changes were made to the survey to make it more understandable.

In the second stage of the validation, the survey was translated into Arabic by the researcher. The rationale for translating the survey into Arabic is to make sure that participants understand all the survey items and to assure 
the validity of the finding. Also, the Arabic language is the first language of the participants. The Arabic version was reviewed by two instructors of the Arabic language program at the University of Texas at Austin holding PhD degrees and one instructor of Arabic language from Saudi Arabia holding a master's degree in Arabic. Based on the comments of the reviewers, a few minor changes were made to the translation.

\section{Pilot study}

The reliability of the survey questionnaire was examined in two stages. In the first stage, the researcher obtained permission from President of King Faisal University (KFU) to conduct the pilot study test of the questionnaire. KFU has 14 colleges and is an official higher education institution. KFU was selected to be the site of the pilot test of the questionnaire because it is another university that offers some e-learning courses and has a similar educational system and size as King Abdulaziz University (KAU). In the second stage, the researcher piloted the Arabic version of the survey and evaluation form at King Faisal University (KFU) during the fall 2008 semester. There are 50 instructors that participated in the pilot study 
The pilot test was given the proposed evaluation form (see Appendix C) and questionnaire. Evaluation instructions were included on the questionnaire. Participants were asked to note areas of difficulty, confusing, or misleading on the questionnaire as they were completing it. The participants were asked to return the completed questionnaire within one week.

The pilot study was able to provide information concerning ambiguities within the questionnaire, thus dealing with the issue of content validity, reliability, and understandability.

In the third stage, after collection of the survey, the statistical reliability of the survey was assessed using Cronbach's alpha coefficient of internal consistency. The analyses were calculated for the entire questionnaire, as well as for part two and three separately (See Table 3.1). These analyses produced a Cronbach's alpha value $(0.944)$ for part two, (0.941) for part three, and (0.946) for the entire survey.

Table 3.1: Reliability of questionnaire

Reliability of Section Two

\begin{tabular}{|r|r|}
\hline $\begin{array}{c}\text { Cronbach's } \\
\text { Alpha }\end{array}$ & N of Items \\
\hline .941 & 27 \\
\hline
\end{tabular}

\section{Reliability of Section Three}

\begin{tabular}{|c|r|}
\hline $\begin{array}{c}\text { Cronbach's } \\
\text { Alpha }\end{array}$ & N of Items \\
\hline .944 & 41 \\
\hline
\end{tabular}

Reliability of Entire Survey

\begin{tabular}{|r|r|}
\hline $\begin{array}{c}\text { Cronbach's } \\
\text { Alpha }\end{array}$ & N of Items \\
\hline .946 & 73 \\
\hline
\end{tabular}


According to (Kerlinger, 1964; Davis, 2000; Muijs, 2004), this instrument has a very high value of coefficient alpha (See Appendix D). Based on the results of the pilot study and the comments from participants, some changes have been made to the instrument to be used in this study.

\section{Data Collection}

The data were collected from two of the fourteen colleges at KAU, the humanities and the science colleges. Each of these colleges has separate male and female sections and surveys will be given to both sections for each of the respective colleges. The participants were selected at random and provided with a paper survey or the address for a website where they could complete the survey electronically. In addition, the main web pages for each of the colleges featured a link to this same website in order to allow more instructors to participate in the survey. The paper surveys were returned to a collection box that was available to the instructors, and the electronic surveys were collected from the website. After three weeks, the colleges were sent a letter from the Center for Research to remind them to return the completed surveys that they had received. Four independent data collectors were used to collect the surveys from the instructors. These measures 
were designed to provide a high response rate for the survey

\section{Procedures for the Analysis of Data}

The analysis of data in this study included three statistical techniques, factor analysis, descriptive statistics, and inferential statistics. The researcher coded and entered data into a database using the Statistical Package for the Social Sciences (SPSS) .

The design of the study included two sets of study questions. Also, it had four dependent variables and three independent variables. The dependent variables included level of current expertise, level of current use, motivational factors, and barrier factors. The independent variables included academic field, years of teaching experience, and sex (see Figure 3.4).

The objective of the study was to answer the study's questions. To answer the first study questions, the researcher used descriptive statistics including means, standard deviations, ranges, frequencies, percentages, and diagrams.

Inferential analysis techniques, including three-way factorial ANOVA (A x B x C Factorial Design), and Scheffe's 
post hoc analysis were used to answer the second set of study questions.

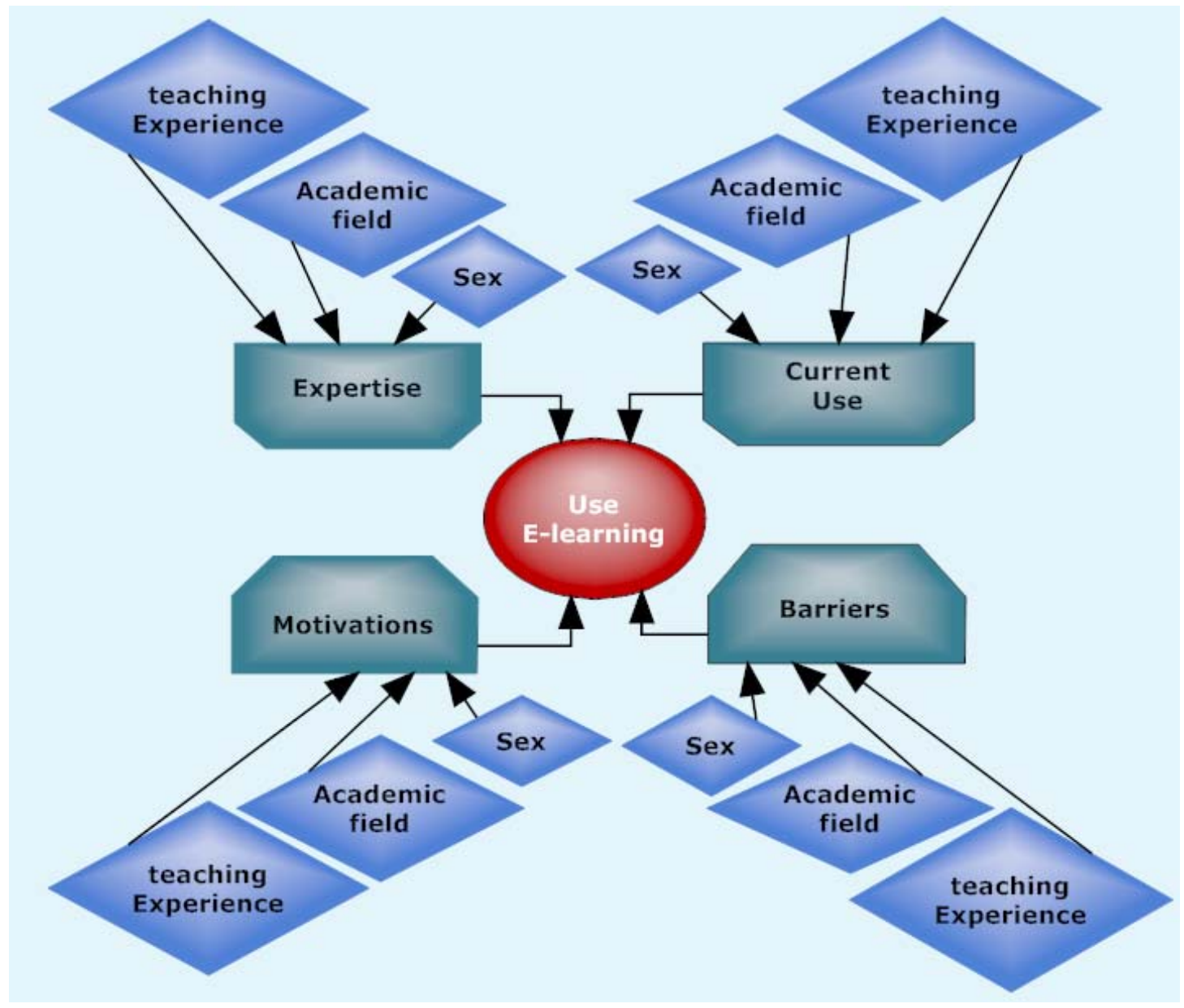

Figure 3.4: Three independent Variables and four dependent Variables.

In particular, a three-way factorial ANOVA was employed to determine whether significant differences exist among instructors from King Abdulaziz University's (KAU) Humanities and Scientific Colleges concerning their use of e-learning technologies based on the three independent 
variables of (A)sex , (B)academic field, and(C)years of teaching experience.

The factor analysis procedure initially was used to develop the questionnaire and give more insight about the variables of the study. That is, to explore and explain relationships among the study variables in order to discover if these variables can be grouped into a smaller set of underlying factors. The following (Table 3.2) presents the relationship between the first set of research questions with survey items. (Table 3.3) presents the relationship between the second set of research questions with survey items

Table 3.2: First set of research questions

\begin{tabular}{|l|l|l|}
\hline \multicolumn{2}{|c|}{ First Set of Questions } & \multicolumn{1}{|c|}{ Survey Items } \\
\hline 1 & $\begin{array}{l}\text { What are instructors' } \\
\text { perceived levels of } \\
\text { technogy expertise? }\end{array}$ & Part II of the Survey, \\
\hline 2 & $\begin{array}{l}\text { That is the current use } \\
\text { instructors? }\end{array}$ & Part II of the Survey, \\
\hline 3 & $\begin{array}{l}\text { What are the intrinsic and } \\
\text { extrinsic factors that } \\
\text { motivate the instructors to } \\
\text { use e-learning in their } \\
\text { teaching? }\end{array}$ & Part III of the Survey, \\
\hline 4 & $\begin{array}{l}\text { That are the intrinsic and } \\
\text { extrinsic factors that } \\
\text { impede the instructors to } \\
\text { use of e-learning in their } \\
\text { teaching? }\end{array}$ & Part III of the Survey, \\
\hline
\end{tabular}


Table 3. 3: Second set of research questions

\begin{tabular}{|l|l|l|}
\hline \multicolumn{2}{|c|}{ Second Set of Questions } & \multicolumn{1}{|c|}{ Survey Items } \\
\hline 1 & $\begin{array}{l}\text { Is there a significant } \\
\text { difference in the perceived } \\
\text { technology expertise of } \\
\text { instructors based on their } \\
\text { academic field, teaching } \\
\text { experience, and sex? }\end{array}$ & Part II of the \\
\hline 2 & $\begin{array}{l}\text { Is there a significant } \\
\text { difference in the use of e- } \\
\text { learning among instructors } \\
\text { based on their academic field, } \\
\text { teaching experience, and sex? }\end{array}$ & items \\
\hline 3 & $\begin{array}{l}\text { Is there a significant } \\
\text { difference in motivational } \\
\text { factors among instructors } \\
\text { based on their academic field, } \\
\text { teaching experience, and sex? }\end{array}$ & items \\
\hline 4 & $\begin{array}{l}\text { Is there a significant } \\
\text { difference in barrier factors } \\
\text { among instructors based on } \\
\text { their academic field, teaching } \\
\text { experience, and sex? }\end{array}$ & Part II of the \\
\hline
\end{tabular}

\section{Summary}

This chapter explained the methodology used to accomplish the purpose of the study. It included research questions, instrument development procedures, research procedures, a description of the study sample, a discussion of the instrumentation employed to answer the research questions, the pilot study, and the description of the data 
analysis. The findings from the analysis of the data are presented in Chapter IV. 


\section{CHAPTER (IV) \\ Results of the Study}

The objective of this chapter is to present the findings of the study. This study consisted of two sets of questions. The first set contained descriptive questions, and the second set contained inferential questions. The study used these questions to determine whether significant differences exist among instructors from King Abdulaziz University's (KAU) Humanities and Scientific Colleges concerning their use of e-learning technologies based on the three independent variables: academic field, years of teaching experience, and sex.

The chapter is presented in three sections. The first section presents the factor analysis findings. It also shows the general demographic characteristics of the population and sample (academic field, years of teaching experience, and sex). This section also includes general and specific technological expertise of the participants, levels of current usage e-learning technologies, motivating factors, and impediment factors. The second section shows the results of inferential statistical analysis of the data to determine whether significant differences exist among instructors from KAU concerning their use of e-learning 
technologies based on the three independent variables: academic field, years of teaching experience, and sex. The third section of the chapter presents a summary of the findings.

\section{General Characteristics of the population and sample}

The population of the study consisted of roughly 2000 instructors from the King Abdulaziz University (KAU) in Saudi Arabia during the academic year of 2007-2008. This population included separate men's and women's sections at the campus in Jeddah. Section one of the survey collected participants' individual information about their sex, academic field, and years of teaching experience. A total of 227 instructors from KAU were analyzed in this study, and the frequency of the participant characteristics are shown below.

Out of the 600 surveys that were distributed, 285 surveys were returned. All of the surveys that included missing data were excluded from analysis. The resulting 227 surveys were analyzed using sPSS software.

The characteristics of the sample based on sex showed that this study contained a majority of female participants. Table (4.1) shows that of the 227 participants in the study 127 of the participants were 
female (55.9\%), and there were 100 male participants (44.1\%) in the study.

Table 4.1: Frequency of participants' sex:

\begin{tabular}{|c|c|c|c|c|c|}
\hline \multicolumn{2}{|c|}{ Sex } & Frequency & Percent & Valid Percent & $\begin{array}{c}\text { Cumulative } \\
\text { Percent }\end{array}$ \\
\hline \multirow[t]{3}{*}{ Valid } & male & 100 & 44.1 & 44.1 & 44.1 \\
\hline & female & 127 & 55.9 & 55.9 & 100.0 \\
\hline & Total & 227 & 100.0 & 100.0 & \\
\hline
\end{tabular}

The characteristics of the participants based on academic field show that this study contained a majority of participants in the field of science. Table (4.2) shows that of the 227 participants, 135 participants (59.5\%) were instructors for the scientific college of KAU. 92 participants $(40.5 \%)$ were instructors for the Humanities college of KAU.

Table 4.2 : Frequency of participants' academic field:

\begin{tabular}{|c|c|c|c|c|c|}
\hline \multicolumn{2}{|c|}{ Academic field } & Frequency & Percent & Valid Percent & $\begin{array}{c}\text { Cumulative } \\
\text { Percent }\end{array}$ \\
\hline \multirow[t]{3}{*}{ Valid } & scientific & 135 & 59.5 & 59.5 & 59.5 \\
\hline & Humanities & 92 & 40.5 & 40.5 & 100.0 \\
\hline & Total & 227 & 100.0 & 100.0 & \\
\hline
\end{tabular}

The frequency of experience of the participants was also analyzed. Experience was operationalized into 4 intervals $(0-5,6-10,11-15$, and over 15 years of teaching experience). Table (4.3) shows that 50 participants (22.0\%) had 0-5 years of experience, 42 participants (18.5\%) had 610 years of experience, 43 participants (18.9\%) had 11-15 
years of experience, and 92 participants (40.5\%) had over 15 years of experience. These findings show that the majority of the participants in this study had over 15 years of teaching experience. A visual representation of this frequency can be seen in Fig. (4.1)

Table 4.3 : Frequency of participants' experience:

\begin{tabular}{|c|c|c|c|c|}
\hline $\begin{array}{c}\text { Years of } \\
\text { Experience }\end{array}$ & Frequency & Percent & Valid Percent & $\begin{array}{c}\text { Cumulative } \\
\text { Percent }\end{array}$ \\
\hline $\begin{array}{ll}\text { Valid } & 0-5\end{array}$ & 50 & 22.0 & 22.0 & 22.0 \\
\hline $6-10$ & 42 & 18.5 & 18.5 & 40.5 \\
\hline $11-15$ & 43 & 18.9 & 18.9 & 59.5 \\
\hline $15+$ & 92 & 40.5 & 40.5 & 100.0 \\
\hline Total & 227 & 100.0 & 100.0 & \\
\hline
\end{tabular}

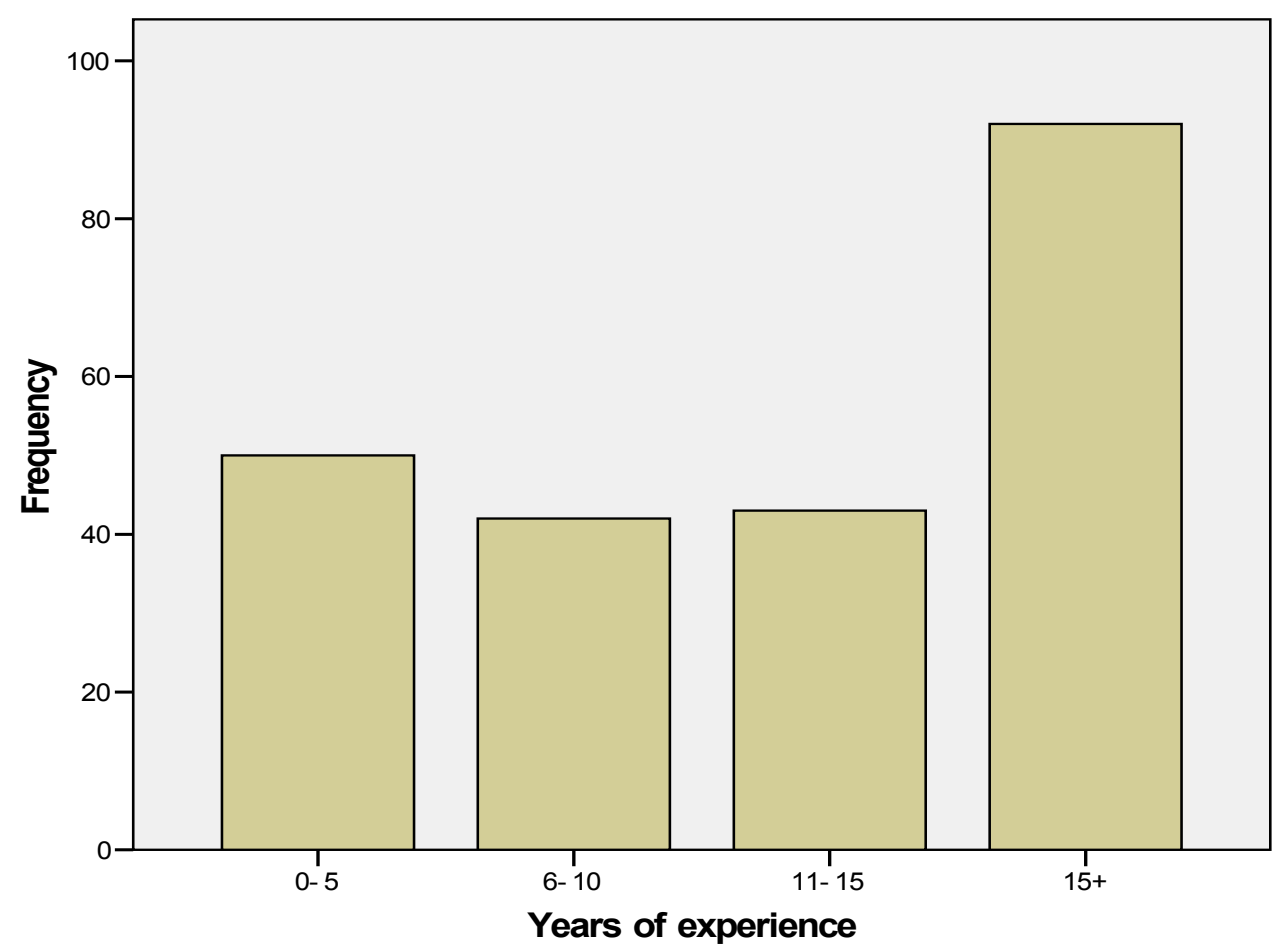

Figure 4.1: Frequency of years of teaching experience 
The frequency of sex by academic field was also analyzed. Table (4.4) shows the distribution of men and women by academic field. 60 men were in the college of science, and 40 men were in the college of humanities. There were 75 females in the college of science and 52 females in the college of humanities. This distribution is represented visually in Fig (4.2).

Table 4.4: Number of participants by their sex and academic field

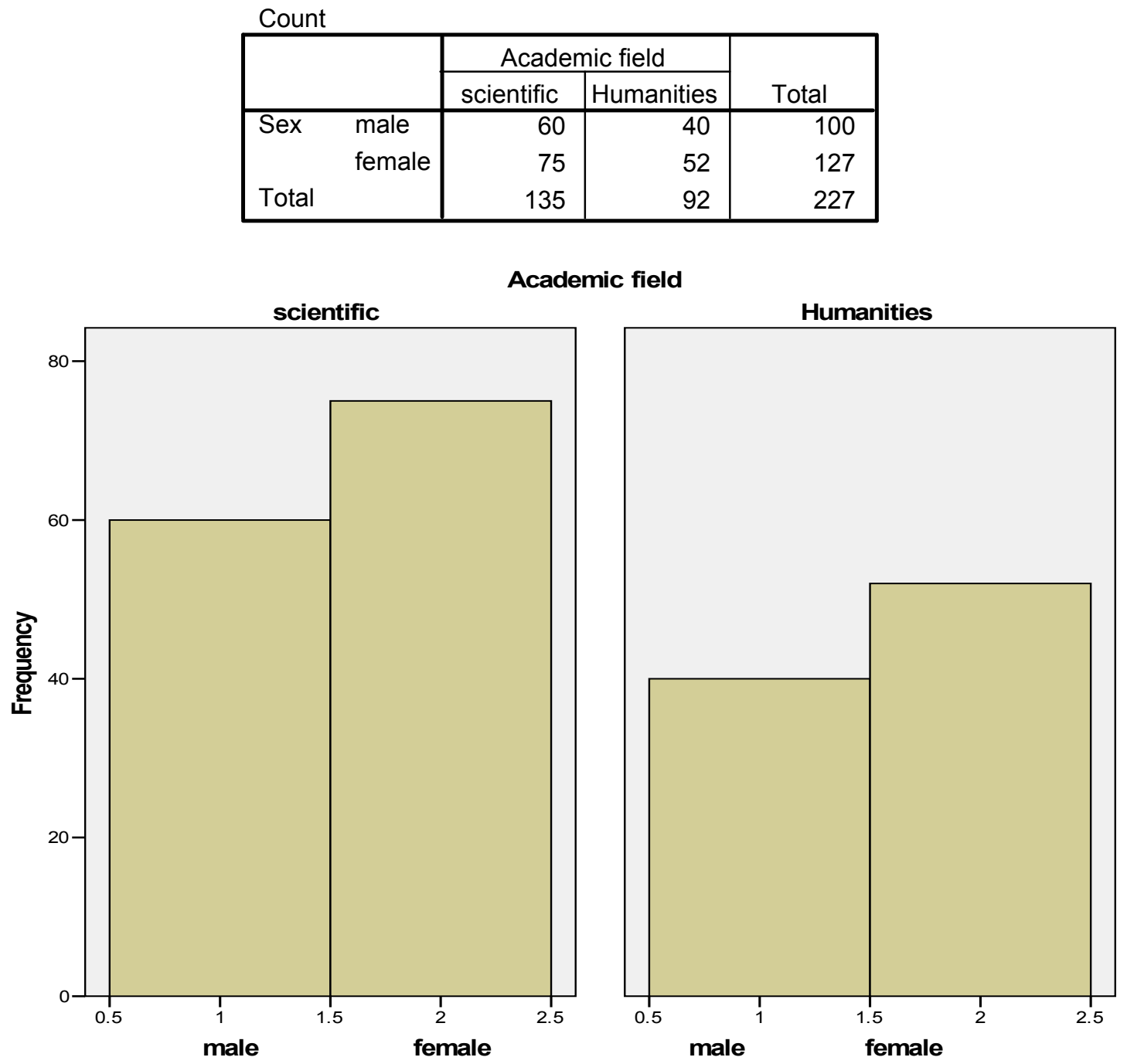

Fig.4.2: Frequency of participants by their sex and academic field 
The frequency of academic field by years of teaching experience was also analyzed. Table (4.5) shows this distribution. This distribution indicates that the largest frequency of academic field by years of experience existed in the scientific field with participants that had over 15 years of experience. The smallest frequency existed in the Humanities college with participants that had 0-5 years of experience.

Table 4.5: Frequency of experience by academic field

Count
\begin{tabular}{|ll|r|r|r|}
\hline & & \multicolumn{2}{|c|}{ Academic field } & \multirow{2}{*}{} \\
\cline { 3 - 4 } & & scientific & Humanities & \multicolumn{1}{c|}{ Total } \\
\hline Experience & $0-5$ & 35 & 15 & 50 \\
& $6-10$ & 16 & 26 & 42 \\
& $11-15$ & 23 & 20 & 43 \\
& $15+$ & 61 & 31 & 92 \\
Total & & 135 & 92 & 227 \\
\hline
\end{tabular}

A Cross table descriptive distribution of sex by years of teaching experience was also analyzed. Table (4.6) shows this distribution and indicates that the majority of male participants (43 participants) had over 15 years of experience. The majority of female participants (49 participants) also had over 15 years of experience. The largest frequency of sex by years of experience occurred with female participants that had over 15 years of 
experience. For a visual representation of this distribution, see Fig. (4.3).

Table 4.6: Frequency of experience by sex:

\begin{tabular}{|c|c|c|c|c|c|c|}
\hline & & \multicolumn{4}{|c|}{ Experience } & \multirow[b]{2}{*}{ Total } \\
\hline & & $0-5$ & $6-10$ & $11-15$ & $15+$ & \\
\hline \multirow[t]{3}{*}{ Sex } & male & 24 & 18 & 15 & 43 & 100 \\
\hline & female & 26 & 24 & 28 & 49 & 127 \\
\hline & & 50 & 42 & 43 & 92 & 227 \\
\hline
\end{tabular}

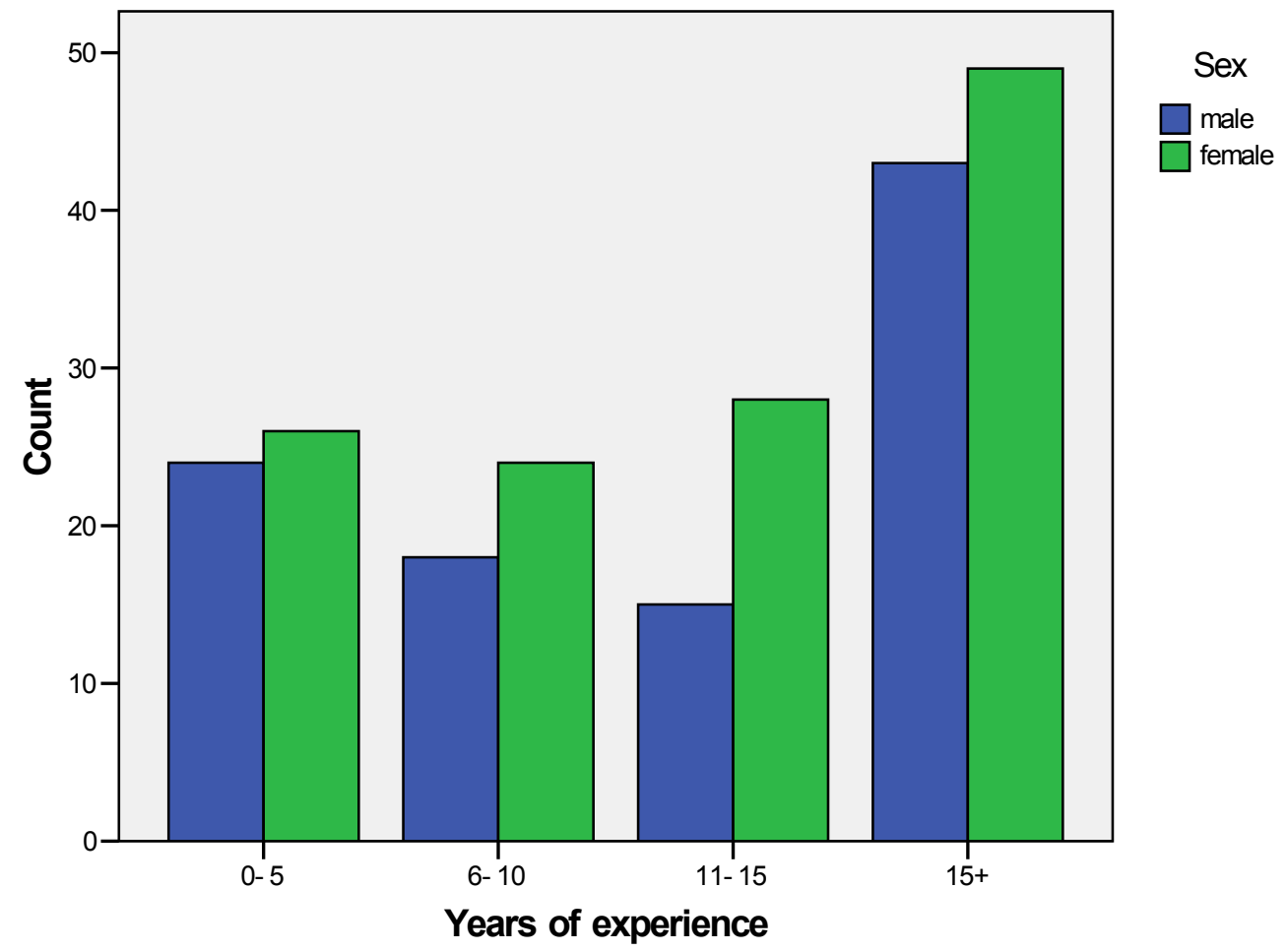

Figure 4.3 : Frequency of experience by sex

\section{General expertise of participants:}

The participants were asked to rate their general expertise as well as 12 specific areas of expertise on a 5 
point Likert-like scale (Don't use $=0$, Novice $=1$, Intermediate $=2$, Proficient $=3$, Expert $=4)$. The mean of the general expertise value was (2.63) of 4 and the standard deviation was 0.843 (see Table 4.7). The mean value reveals that the majority of participants in this study have a positive sense of general expertise.

Table 4.7: Descriptive of general expertise

\begin{tabular}{|l|r|r|r|r|r|}
\hline Variables & \multicolumn{1}{|c|}{$\mathrm{N}$} & \multicolumn{1}{|c|}{ Minimum } & Maximum & \multicolumn{1}{c|}{ Mean } & Std. Deviation \\
\hline Genral Expertise & 227 & 0 & 4 & 2.63 & .843 \\
Valid N (listwise) & 227 & & & & \\
\hline
\end{tabular}

The entire breakdown of the distribution for general expertise can be seen in Table (4.8) and Fig. (4.4). This distribution shows that the majority of participants (116 participants or $51.1 \%$ ) rated themselves as proficient. As shown in (Appendix E), the majority of these participants with proficient expertise can be found in the college of science. In addition, only four participants rated themselves as having no expertise, and all four participants were found in the Humanities college.

Table 4.8: Frequency of general expertise

\begin{tabular}{|c|c|c|c|c|c|}
\hline \multicolumn{6}{|c|}{ Genral Expertise } \\
\hline & & Frequency & Percent & Valid Percent & $\begin{array}{l}\text { Cumulative } \\
\text { Percent }\end{array}$ \\
\hline \multirow[t]{6}{*}{ Valid } & Don't use & 4 & 1.8 & 1.8 & 1.8 \\
\hline & Novice & 16 & 7.0 & 7.0 & 8.8 \\
\hline & Intermediate & 65 & 28.6 & 28.6 & 37.4 \\
\hline & Proficient & 116 & 51.1 & 51.1 & 88.5 \\
\hline & Expert & 26 & 11.5 & 11.5 & 100.0 \\
\hline & Total & 227 & 100.0 & 100.0 & \\
\hline
\end{tabular}


Fig. (4.5) provides a visual representation of the general expertise by academic field.

\section{Genral Expertise}

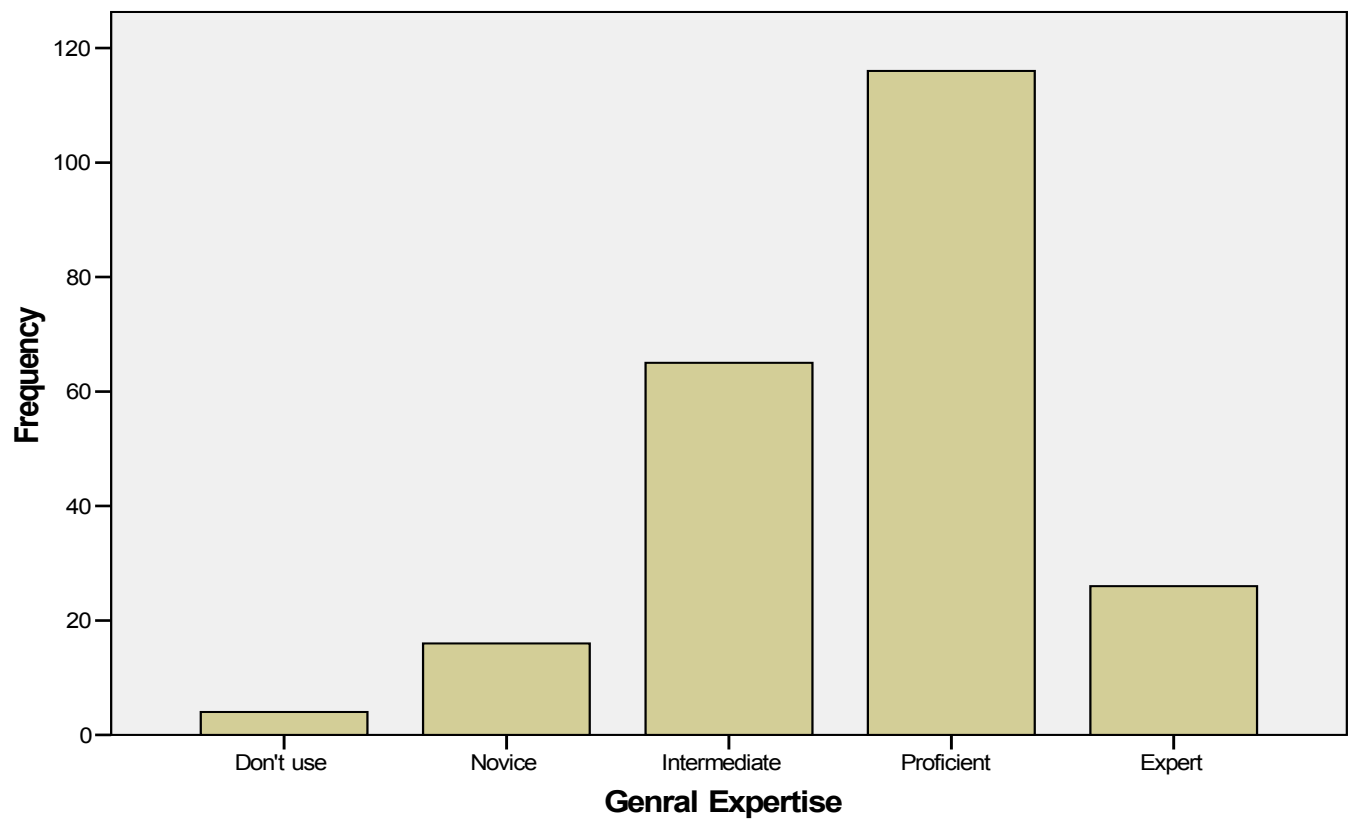

Figure 4.4: Frequency of general expertise

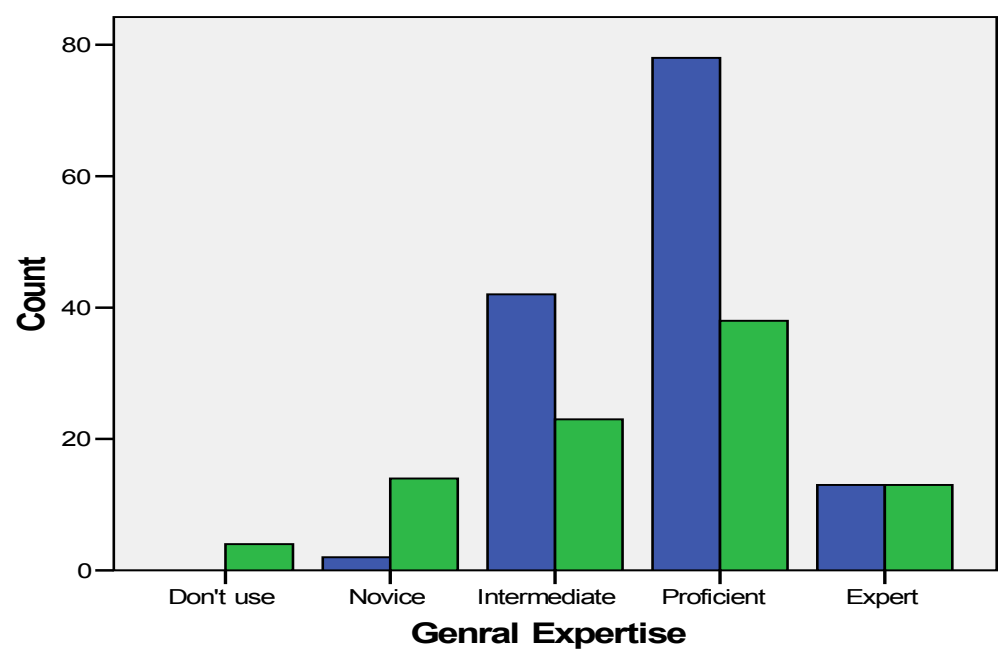

Academic field

$\square$ scientific

Humanities

Figure 4.5: Frequency of general expertise by academic field 
The frequency of sex and general expertise was also analyzed, see (Appendix F). This distribution shows that the largest frequency occurred with females who rated themselves as proficient. None of the female participants, however, rated themselves as experts, but 23 male participants chose the rating of expert. On the other hand, no male participants chose the rating of no expertise, but 4 females chose this rating, see Fig. (4.6).

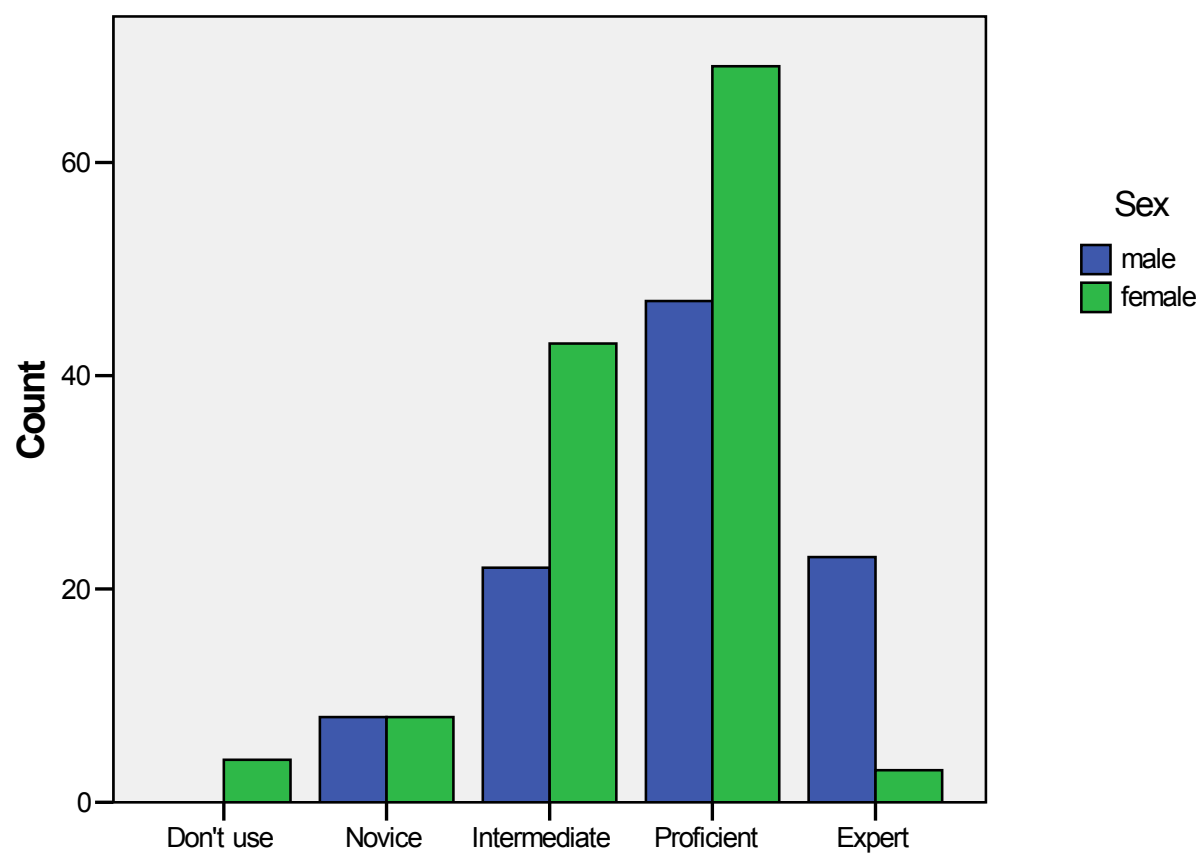

Genral Expertise

Figure 4.6: Frequency of general expertise by sex

\section{Specific expertise of participants}

Along with the general expertise, participants rated their expertise in 12 specific areas with the same 5 point Likert-like scale that was used for general expertise. The 
mean value for specific expertise was positive (2.33), and the majority of participants (78.3\%) rated themselves as being at least "Intermediate" with specific expertise (see Table 4.10). From an analysis of the data, the top three specific items of expertise include 1) Using a computer to find resources from the university library, 2) Using a word processor to create documents, 3) Using presentation software (e.g., PowerPoint); the lower three specific items of expertise include 1) Website design, 2) Use of electronic bulletin board, and 3) Use video conferencing (see Table 4.9).

Table 4.9: Factors of specific expertise:

\begin{tabular}{|l|l|r|r|}
\hline \multicolumn{1}{|c|}{ Factors of Expertise } & N & Mean & \multicolumn{1}{c|}{$\begin{array}{c}\text { Std. } \\
\text { Deviation }\end{array}$} \\
\hline 3- Use a computer to find resources from the & 227 & 3.04 & 1.008 \\
university library. & 227 & 2.94 & .985 \\
1- Use a word processor to create documents. & 227 & 2.81 & 1.192 \\
6- Use presentation software (e.g., PowerPoint). & 227 & 2.66 & 1.170 \\
4- Searching the web to find information and & 227 & 2.53 & 1.176 \\
resources. & 227 & 2.52 & 1.263 \\
2- Use a spreadsheet to create charts and graphs. & & 2.37 & 1.368 \\
5- Use a database software to set up and access & & & \\
information. & & 2.24 & 1.261 \\
10- Use a computer to communicate with others. & 227 & 2.05 & 1.323 \\
7- Use graphic software to create illustrations, slides, & & 1.33 & 1.320 \\
or images. & 227 & 1.15 & 1.320 \\
8- Use audio/video clips software to create or & 227 & 1.13 & 1.307 \\
enhance presentations. & 227 & & \\
9- Website design. & &
\end{tabular}


Table 4.10: Descriptive of specific expertise:

\begin{tabular}{|c|r|r|l|r|}
\hline SPECIFIC EXPERTIS & Frequency & Percent & Statistics & \\
\hline Don't use & 3 & 1.3 & & \\
Novice & 46 & 20.3 & Mean & 2.33 \\
Intermediate & 80 & 35.2 & Std. Deviation & .977 \\
Proficient & 70 & 30.8 & Minimum & 0 \\
Expert & 28 & 12.3 & Maximum & 4 \\
Total & 227 & 100.0 & & \\
\hline
\end{tabular}

\section{Current use e-learning by participants:}

Participants also rated their current use of elearning with 15 specific items using a 5 point Likert-like scale $[0=$ Never $(0 \%), 1=\operatorname{Seldom}(1-25 \%), 2=$ occasionally $(26-50 \%), 3=$ Often (51-75\%), $4=$ Almost all the time (76100\%)]. The mean value for current use was negative (1.41), and the majority of participants (63.4\%) rated themselves as "Seldom" using e-learning technologies (see Table 4.11). An analysis of this distribution indicated that the top three items of current use include 1) Internet research and searches, 2) Computer software for handouts or lecture notes, and 3) Presentation software in the classroom; the lower three items of current use include 1) Electronics conferencing, 2) Use personally designed Web-based lectures, notes, or tutorials, and 3) Use personally designed Web-based tests or quizzes (See Table 4.12). This table shows the mean and standard deviation value for all 15 items of current use. 
Table 4.11: Descriptive of current use e-learning

\begin{tabular}{|l|r|r|l|c|}
\hline CURRENT USE & Frequency & Percent & Statistics & \\
\hline Never & 5 & 2.2 & & \\
Seldom & 144 & 63.4 & Mean & 1.41 \\
Occasionally & 61 & 26.9 & Std. Deviation & .714 \\
Often & 13 & 5.7 & Minimum & 0 \\
Almost & 4 & 1.8 & Maximum & 4 \\
Total & 227 & 100.0 & & \\
\hline
\end{tabular}

Table 4.12: Factors of current use of e-learning

\begin{tabular}{|c|c|c|c|}
\hline Factors of Current Use & $\mathrm{N}$ & Mean & Std. Deviation \\
\hline 9- Used Internet research and searches. & 227 & 3.02 & 1.244 \\
\hline $\begin{array}{l}\text { 1- Use of computer software for handouts or lecture } \\
\text { notes. }\end{array}$ & 227 & 2.60 & 1.380 \\
\hline 4- Use of presentation software in the classroom. & 227 & 2.19 & 1.558 \\
\hline 3- Hold virtual office hours. & 227 & 1.50 & 1.415 \\
\hline $\begin{array}{l}\text { 2- Use Email as the primary source of student } \\
\text { contact outside the classroom. }\end{array}$ & 227 & 1.46 & 1.380 \\
\hline 8- Provided web-based grades. & 227 & 1.37 & 1.587 \\
\hline 10- Posting required readings on course web page. & 227 & 1.37 & 1.452 \\
\hline 14- Use video tapes for instruction. & 227 & 1.14 & 1.221 \\
\hline 15- Use audio tapes for instruction. & 227 & .86 & 1.104 \\
\hline 11- Use On-line Chat room & 227 & .83 & 1.179 \\
\hline 5- Use On-line bulletin board. & 227 & .80 & 1.122 \\
\hline 12- Commenting on course work electronically. & 227 & .67 & 1.114 \\
\hline 13- Electronics conferencing. & 227 & .54 & .946 \\
\hline $\begin{array}{l}\text { 6- Use personally designed Web-based lectures, } \\
\text { notes, or tutorials. }\end{array}$ & 227 & .52 & .966 \\
\hline $\begin{array}{l}\text { 7- Use personally designed Web-based tests or } \\
\text { quizzes. }\end{array}$ & 227 & .43 & .963 \\
\hline
\end{tabular}

\section{Motivation of participants}

The motivation of the participants for using elearning was also found by using a 5 point Likert-like scale [Highly Discouraging $(\mathrm{HD})=0$, Discouraging $(\mathrm{D})=1$, Not a Factor $(\mathrm{NF})=2$, Encouraging $(\mathrm{E})=3$, Highly 
Encouraging $(\mathrm{HE})=4]$. The mean value for motivation was positive (2.99), and the majority of participants (78.5\%) rated motivational factors as being "Encouraging" or "Highly Encouraging" (see Table 4.13). The top three motivational factors included 1) personal computer skills, 2) the opportunity to improve teaching, and 3) classroom technology infrastructure (e.g., wiring, computers, or projectors); The lower three motivational factors included 1) Support and encouragement from peers, 2) Opportunity to reach new audience that can not attend classes on campus, and 3) Credit toward promotion and tenure, (see Table 4.14). These factors were also analyzed in terms of being extrinsic or intrinsic, and the top two motivational factors were found to be intrinsic. These results show that intrinsic motivational factors are more important than extrinsic factors in encouraging an instructor to adopt and use e-learning. This finding is in accordance with the findings of the literature review in this study.

Table 4.13: Motivational factors

\begin{tabular}{|c|r|r|l|r|}
\hline MOTIVATION & Frequency & Percent & Statistics & \\
\hline Highly Discouraging & 3 & 1.3 & & \\
Discouraging & 15 & 6.6 & Mean & 2.99 \\
Not a Factor & 31 & 13.7 & & \\
Encouraging & 110 & 48.5 & Std. Deviation & .907 \\
Highly Encouraging & 68 & 30.0 & Minimum & 0 \\
Total & 227 & 100.0 & Maximum & 4 \\
\hline
\end{tabular}


Table 4.14: Motivational factors

\begin{tabular}{|c|c|c|c|c|}
\hline Factor of Motivations & $\mathrm{N}$ & $\begin{array}{l}\text { Type of } \\
\text { Factor }\end{array}$ & Mean & $\begin{array}{c}\text { Std. } \\
\text { Deviation }\end{array}$ \\
\hline 21- My computer skills & 227 & Intrinsic & 3.25 & .969 \\
\hline 10- Opportunity to improve teaching & 227 & Intrinsic & 3.23 & .917 \\
\hline $\begin{array}{l}17-\text { Classroom technology infrastructure (e.g., } \\
\text { wiring , computers, or projectors) }\end{array}$ & 227 & Extrinsic & 3.22 & 1.151 \\
\hline $\begin{array}{l}\text { 18- Resources about how to apply technology in } \\
\text { teaching. }\end{array}$ & 227 & Extrinsic & 3.18 & 1.345 \\
\hline 19- Student' access to resources & 227 & Extrinsic & 3.15 & 1.144 \\
\hline 15- Opportunity for scholarly pursuit & 227 & Intrinsic & 3.07 & 1.124 \\
\hline 16- Funding for materials/expenses & 227 & Extrinsic & 3.07 & 1.212 \\
\hline $\begin{array}{l}\text { 23- Opportunity to enhance communication with } \\
\text { others. }\end{array}$ & 227 & Extrinsic & 3.05 & 1.014 \\
\hline 20- Student' computer skills & 227 & Extrinsic & 3.00 & 1.144 \\
\hline 22- My colleagues' computer skills & 227 & Extrinsic & 2.99 & .975 \\
\hline 2- Administrative encouragement and support & 227 & Extrinsic & 2.96 & 1.064 \\
\hline 8- Training programs and support & 227 & Extrinsic & 2.95 & 1.145 \\
\hline $\begin{array}{l}\text { 12- Time available to learn/pursue the integration of } \\
\text { e-learning technologies }\end{array}$ & 227 & Extrinsic & 2.93 & 1.197 \\
\hline 11- Rewards/recognition for innovation in teaching & 227 & Extrinsic & 2.92 & 1.270 \\
\hline $\begin{array}{l}5-\text { Access to software tools for enhancing teaching } \\
\text { with technology }\end{array}$ & 227 & Extrinsic & 2.88 & 1.186 \\
\hline 3- Technical support in solving computer problems & 227 & Extrinsic & 2.88 & 1.187 \\
\hline 13-Increase in salary. & 227 & Extrinsic & 2.83 & 1.307 \\
\hline 9- Reduced teaching load. & 227 & Extrinsic & 2.82 & 1.165 \\
\hline 7- Professional prestige and status & 227 & Intrinsic & 2.79 & 1.166 \\
\hline 1- Requirement by department or university & 227 & Extrinsic & 2.77 & 1.129 \\
\hline 4- Support and encouragement from peers & 227 & Extrinsic & 2.77 & 1.078 \\
\hline $\begin{array}{l}\text { 14- Opportunity to reach new audience that can } \\
\text { not attend classes on campus. }\end{array}$ & 227 & Intrinsic & 2.73 & 1.221 \\
\hline 6- Credit toward promotion and tenure & 227 & Intrinsic & 2.62 & 1.215 \\
\hline
\end{tabular}

\title{
Barriers for participants
}

\author{
The barriers for the participants to use e-learning \\ were also found by using a 5 point Likert-like scale $[0=$ \\ No barriers (NB), 1 = Very few barriers (VFB), 2 = Few \\ barriers (FB), $3=$ some barriers (SB), $4=$ Many barriers \\ (MB)]. The mean value for barriers was positive (2.70), and
}


the majority of participants (64.7\%) rated barrier factors as being "Some" or "Many" (see Table 4.15). Table 4.11 shows this distribution of barrier factors and includes the mean and standard deviation for each. The top three barrier factors included 1)lack of technological infrastructure, 2) lack of students' access to resources, and 3) lack of technical support in solving computer problems; The top three barrier factors included 1) Security concerns, 2) Lack of support and encouragement from peers, and 3) Negative comments made by colleagues about e-learning technologies, (See Table 4.16). All of these barriers are extrinsic factors, and this finding shows that extrinsic barrier factors are more inhibitive than intrinsic factors.

Table 4.15: Barrier Factors

\begin{tabular}{|l|r|r|l|r|}
\hline BARRIERS & Frequency & Percent & Statistics & \\
\hline No barriers & 2 & .9 & & \\
very few barriers & 17 & 7.5 & Mean & 2.70 \\
few barriers & 61 & 26.9 & Std. Deviation & .840 \\
some barriers & 114 & 50.2 & Minimum & 0 \\
many barrier & 33 & 14.5 & Maximum & 4 \\
Total & 227 & 100.0 & & \\
\hline
\end{tabular}

\section{The result of factor analysis}

The object this section was to present the findings of the factor analysis conducted to investigate the four dependent variables of the study: 1. technology expertise, 
2. current use of e-learning, 3. motivation to use elearning, and 4. barriers of using e-learning.

Table 4.16: Barrier Factors

\begin{tabular}{|c|c|c|c|c|}
\hline $\begin{array}{c}\text { Factor of Barriers } \\
\end{array}$ & $\mathrm{N}$ & $\begin{array}{l}\text { Type of } \\
\text { Factor }\end{array}$ & Mean & $\begin{array}{c}\text { Std. } \\
\text { Deviation }\end{array}$ \\
\hline 15- Lack of technological infrastructure. & 227 & Extrinsic & 3.20 & 1.125 \\
\hline 16- Lack of Student' access to resources. & 227 & Extrinsic & 3.16 & 1.210 \\
\hline $\begin{array}{l}\text { 14- Lack of technical support in solving computer } \\
\text { problems. }\end{array}$ & 227 & Extrinsic & 3.10 & 1.122 \\
\hline 11- Lack of funding for materials/expenses. & 227 & Extrinsic & 3.07 & 1.113 \\
\hline 8- Lack of training programs. & 227 & Extrinsic & 3.02 & 1.054 \\
\hline $\begin{array}{l}\text { 17- Lack of resources about how to apply } \\
\text { technology in teaching. }\end{array}$ & 227 & Extrinsic & 2.93 & 1.210 \\
\hline 7- Lack of students' technological knowledge. & 227 & Extrinsic & 2.88 & 1.180 \\
\hline 6- Lack of instructors' technological knowledge. & 227 & Intrinsic & 2.82 & 1.285 \\
\hline $\begin{array}{l}\text { 4- Lack of support and encouragement from } \\
\text { administrative. }\end{array}$ & 227 & Extrinsic & 2.74 & 1.332 \\
\hline $\begin{array}{l}\text { 9- Lack of face-to-face interaction in e-learning } \\
\text { courses. }\end{array}$ & 227 & Intrinsic & 2.73 & 1.224 \\
\hline 2-Lack of time to learn new technology & 227 & Extrinsic & 2.68 & 1.154 \\
\hline 1- Lack of interest. & 227 & Intrinsic & 2.66 & 1.298 \\
\hline $\begin{array}{l}\text { 12- Lack of rewards/recognition for innovation in } \\
\text { teaching }\end{array}$ & 227 & Extrinsic & 2.54 & 1.311 \\
\hline 13- Concern about course quality. & 227 & Intrinsic & 2.26 & 1.516 \\
\hline 10- Lack of credit toward promotion and tenure. & 227 & Intrinsic & 2.19 & 1.422 \\
\hline 18- Security concerns. & 227 & Intrinsic & 2.17 & 1.405 \\
\hline 5- Lack of support and encouragement from peers. & 227 & Extrinsic & 1.84 & 1.421 \\
\hline $\begin{array}{l}\text { 3- Negative comments made by colleagues about } \\
\text { e-learning technologies. }\end{array}$ & 227 & Extrinsic & 1.60 & 1.455 \\
\hline
\end{tabular}

\title{
Technology Expertise
}

\author{
The factor analysis was conducted to investigate the \\ items of the first variable: technology expertise. Namely, \\ the KMO and Bartlett's test was conducted first to show \\ weather to use factor analysis or not. The value of the \\ test (see Table 4 .17) was significant (.902) which means
}


the use of factor analysis was appropriate. The researcher then conducted the Principle Components Analysis method to extract the data. The 12 items of the variable were grouped into two factors and the cumulative variance of these two factors was (69.38\%). See appendix (L) for details.

Table 4.17: KMO and Bartlett's test for technology expertise

KMO and Bartlett's Test

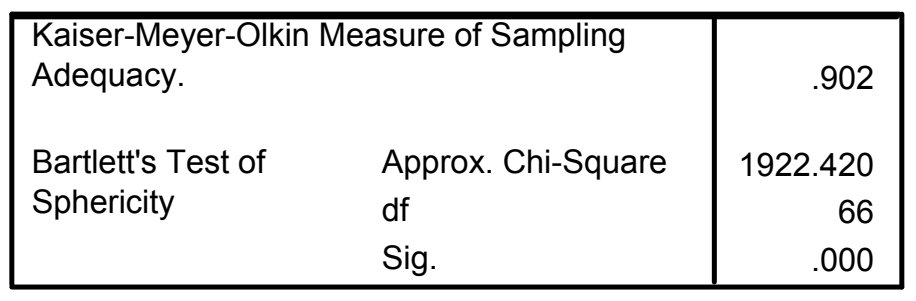

\section{Current Use of e-Learning}

The factor analysis was conducted to explore the second variable of the study: current use of e-learning. The result of $\mathrm{KMO}$ and Bartlett's test (see Table 4.18) was significant (.887). The Principle Components Analysis method was conducted.

Table 4.18: KMO and Bartlett's test for current usage of e-learning

KMO and Bartlett's Test

\begin{tabular}{|c|c|c|}
\hline $\begin{array}{l}\text { Kaiser-Meyer-OI } \\
\text { Adequacy. }\end{array}$ & asure of Sampling & .887 \\
\hline $\begin{array}{l}\text { Bartlett's Test of } \\
\text { Sphericity }\end{array}$ & $\begin{array}{l}\text { Approx. Chi-Square } \\
\text { df } \\
\text { Sig. }\end{array}$ & $\begin{array}{r}1921.710 \\
105 \\
.000\end{array}$ \\
\hline
\end{tabular}


The items were loaded into three factors. The cumulative variance of the three factors was (65.01\%). See appendix (M) for details.

\section{Motivation for Use e-Learning}

The KMO and Bartlett's test results (See Table 4.19) were significant (.951). The Principle Components Analysis method grouped the 23 items into 4 factors. The cumulative variance of the four factors was (73.79\%). For details, see appendix (N)

Table 4.19: KMO and Bartlett's test for motivation to use e-learning

KMO and Bartlett's Test

\begin{tabular}{|c|c|c|}
\hline \multicolumn{2}{|c|}{$\begin{array}{l}\text { Kaiser-Meyer-Olkin Measure of Sampling } \\
\text { Adequacy. }\end{array}$} & .951 \\
\hline $\begin{array}{l}\text { Bartlett's Test of } \\
\text { Sphericity }\end{array}$ & $\begin{array}{l}\text { Approx. Chi-Square } \\
\text { df } \\
\text { Sig. }\end{array}$ & $\begin{array}{r}4752.417 \\
253 \\
.000\end{array}$ \\
\hline
\end{tabular}

\section{Barriers of using e-Learning}

Similar to the three variables, the KMO and Bartlett's test results (See Table 4.20) were significant (.887). The 18 items of the variable were grouped into 4 factors to represent (64.42\%) of the cumulative variance. See appendix (O) for more details. 
Table 4.20: KMO and Bartlett's test for barriers of using e-learning

KMO and Bartlett's Test

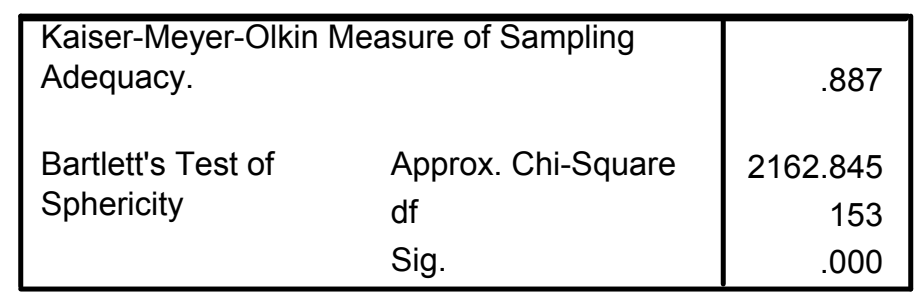

The findings of factor analysis showed that the questionnaires of the study were appropriate to answer the research questions. They also revealed that the variables of the study were appropriately selected to achieve the study goal. Interestingly, the findings of the factor analysis were consistent with the findings of the descriptive techniques used to answer the first set of the research question. For example, the findings of technology expertise variable in descriptive techniques and factor analysis divided the 12 items of the questionnaire into two groups. The first group (9 items) includes items that revealed the skills that most of technology users master. The second group (3 items) showed the skills that advanced user of technology master (See Table 4.21) and (figure $4.7)$. 
Table 4.21: Factors of specific expertise:

\begin{tabular}{|l|l|r|r|}
\hline \multicolumn{1}{|c|}{ Factors of Expertise } & N & Mean & \multicolumn{1}{|c|}{$\begin{array}{c}\text { Std. } \\
\text { Deviation }\end{array}$} \\
\hline 3- Use a computer to find resources from the & 227 & 3.04 & 1.008 \\
university library. & 227 & 2.94 & .985 \\
1- Use a word processor to create documents. & 227 & 2.81 & 1.192 \\
6- Use presentation software (e.g., PowerPoint). & 227 & 2.66 & 1.170 \\
4- Searching the web to find information and & 227 & 2.53 & 1.176 \\
resources. & 227 & 2.52 & 1.263 \\
2- Use a spreadsheet to create charts and graphs. & & & \\
5- Use a database software to set up and access & 227 & 2.37 & 1.368 \\
information. & 227 & 2.24 & 1.261 \\
10- Use a computer to communicate with others. & & & \\
7- Use graphic software to create illustrations, slides, & 227 & 2.05 & 1.323 \\
or images. & 227 & 1.33 & 1.320 \\
8- Use audio/video clips software to create or & 227 & 1.15 & 1.320 \\
enhance presentations. & 227 & 1.13 & 1.307 \\
9- Website design. & & \\
11- Use of electronic bulletin board. & & \\
12- Use video conferencing & & & \\
\hline
\end{tabular}

\section{Component Plot in Rotated Space}

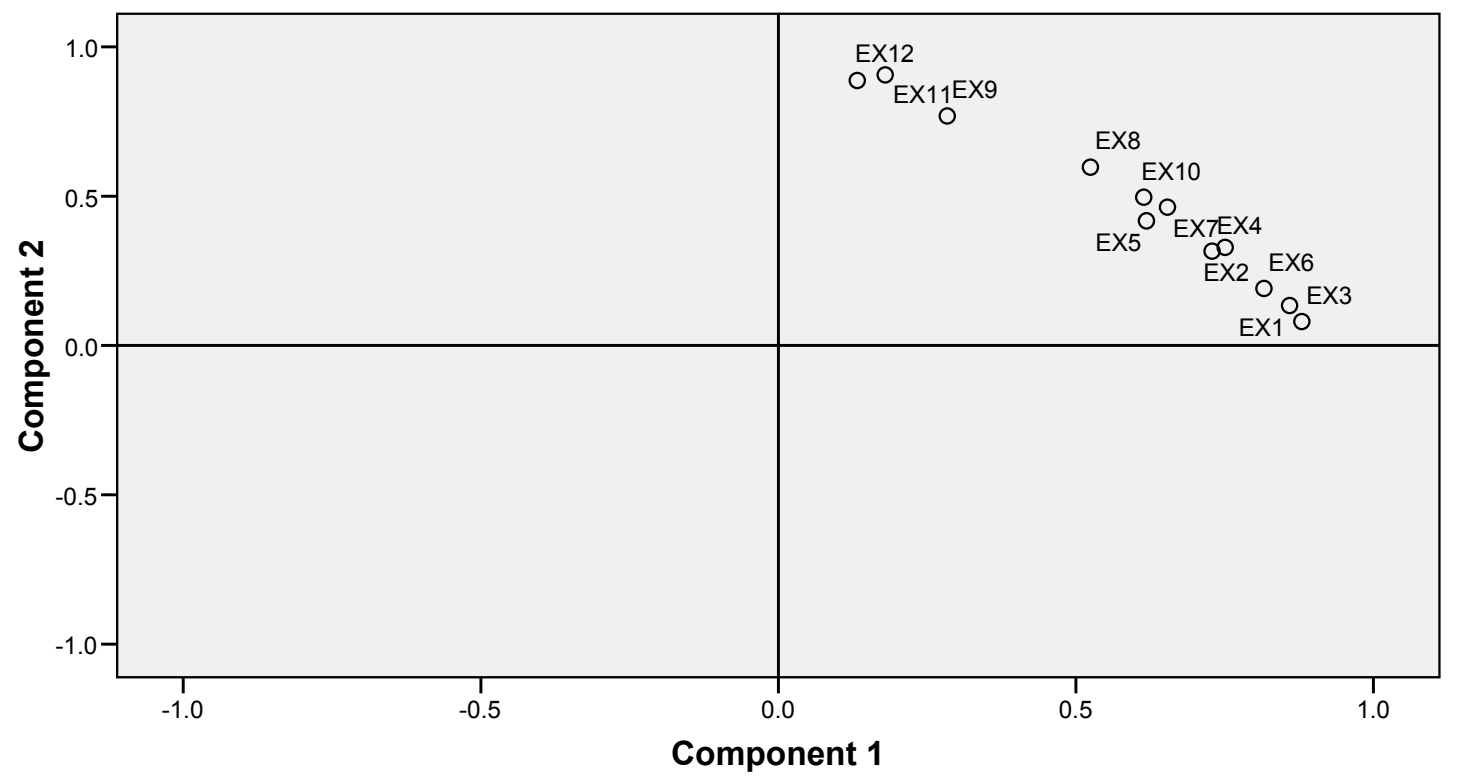

Figure 4.7: Component plot in rotated space for expertise 


\section{The results of inferential statistics}

The objective of this section was to investigate potential differences among participants regarding four dependent variables (expertise, current use, motivation, and barriers) by three independent variables (academic field, teaching experience, and sex) at the 0.05 level of significance.

The statistical method of 3-way factorial ANOVA (A $x$ B $x$ C Factorial Design) as the number 2x2x4 and Scheffe's Post Hoc Analysis (for experience) was used to test the four null hypotheses. The four null hypotheses state that there are no differences among the seven means for each null hypothesis: in symbols,

$$
\mu_{\mathrm{oA}}=\mu_{\mathrm{oB}}=\mu_{\mathrm{oC}}=\mu_{\mathrm{o} A \mathrm{~B}}=\mu_{\mathrm{o} A C}=\mu_{\mathrm{oBC}}=\mu_{\mathrm{o} A \mathrm{BC}}
$$

Ho1: There is no significant difference in the technology expertise of instructors based on (A) their sex, (B) their academic field, and (C) their teaching experience.

The 3-way factorial ANOVA consists of seven hypothesis tests, each evaluating specific mean differences: the A effect, the B effect, the C effect, the A x B interaction, the A $\mathrm{x}$ C interaction, the $\mathrm{B} \times \mathrm{x}$ C interaction, and the A $\mathrm{x} B$ x C interaction:

Main effect $A: \mu \operatorname{sex}($ male $)=\mu$ sex (female) 
Main effect $B: \mu$ academic field (scientific) $=\mu$ academic field (humanities)

Main effect $C: \mu$ experience (0-5) $=\mu$ experience (6-11) $=\mu$ experience (11-15) $=\mu$ experience (over 15)

Interaction $\mathrm{AB}: \mu \operatorname{sex}($ male) academic field (scientific) $=\mu$ sex (male) academic field (humanities)

$=\mu \operatorname{sex}($ female) academic field (scientific) $=\mu \operatorname{sex}($ female) academic field (humanities)

Interaction $\mathrm{AC}: \mu$ sex (male) experience (0-5) $=\mu$ sex (male) experience (6-10) $=\mu$ sex (male) experience

$(11-15)=\mu \operatorname{sex}($ male) experience (over 15) $=\mu$ sex (female) experience (0- 5) $=\mu$ sex

(female) experience $(6-10)=\mu$ sex (female) experience $(11-15)=\mu$ sex (female)

experience (over 15)

Interaction $\mathrm{BC}: \mu$ academic field (scientific) experience (0-5) $=\mu$ academic field (scientific) experience (6-10)

$=\mu$ academic field (scientific) experience (11-15) $=\mu$ academic field (scientific) experience

(over 15) $=\mu$ academic field (humanities) experience (0- 5) $=\mu$ academic field (humanities)

experience $(6-10)=\mu$ academic field (humanities) experience $(11-15)=\mu$ academic field

(humanities) experience (over 15)

Interaction $\mathrm{ABC}: \boldsymbol{\mu}$ sex (male) academic field (scientific) $=\mu$ sex (male) academic field (humanities)

$=\mu$ sex (female) academic field (scientific) $=\mu$ sex (female) academic field (humanities) $\mu$ sex

(male) experience (0-5) $=\mu$ sex (male) experience (6-10) $=\mu$ sex (male) experience (11- 15)

$=\mu_{\text {sex (male) experience (over 15) }}=\mu$ sex (female) experience (0- 5) $=\mu$ sex (female)

experience $(6-10)=\mu \operatorname{sex}($ female) experience $(11-15)=\mu \operatorname{sex}($ female) experience (over 15)

$=\mu$ academic field (scientific) experience $(0-5)=\mu$ academic field (scientific) experience (6 -

10) $=\mu$ academic field (scientific) experience (11- 15) $=\mu$ academic field (scientific) 


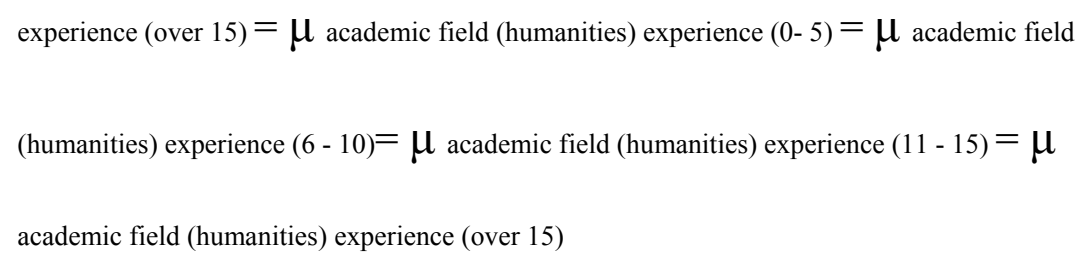

The results of each of the three main effects are briefly presented. Results presented on each main effect are the means, levels of significance and post hoc comparisons, if the results proved to be significant. These results are shown for all the null hypotheses.

\title{
General technology expertise
}

\author{
Main Effect A (Sex: male versus female) \\ The results (See Table 4.22) indicated that there
} was a significant difference in the general technology expertise of instructors based on their sex ( $\mathrm{F}=10.244 ; \mathrm{P}=$ $.002)$ with $(\alpha=0.05)$. The null Hypothesis for the main effect $A$ was rejected. The men showed a higher mean value than the women, and this finding shows that men rate themselves as having a higher level of general expertise. As shown in Table 4.22, the effect size of this significant difference as measured by partial Eta squared was 0.046, which is a small effect. Further details are in (Appendix G) .

Main Effect $B$ (Academic field: Scientific versus Humanities) 
The results (See Table 4.22) indicated that there was a significant difference in the general technology expertise of instructors based on their academic field ( $F=$ 6.752; $\mathrm{P}=0.010)$ with $(\alpha=0.05)$. The null Hypothesis for the main effect $B$ was rejected. The scientific field showed a higher mean value than the humanities field, and this finding shows that the scientists rate themselves as having a higher level of general expertise. As shown in Table (4.22), the effect size of this significant difference as measured by partial Eta squared was 0.031 , which is a small effect. Further details are in (Appendix G) .

\section{Main Effect $C$ (experience: four categories)}

The results (See Table 4.22) indicated that there was a significant difference in the general technology expertise of instructors based on their experience ( $\mathrm{F}=$ 3.078; $\mathrm{P}=0.029)$ with $(\alpha=0.05)$. The null Hypothesis for the main effect $C$ was rejected. As shown in Table 4.22, the effect size of this significant difference as measured by partial Eta squared was 0.042 , which is a small effect. Further details are in (Appendix C). Scheffe's Post Hoc Analysis was also conducted for experience, and the results of this analysis can be found in Appendix G. 


\section{$A B$ Interaction (Sex \& Academic field)}

The results (See Table 4.22) indicated that there was a significant difference in the general technology expertise of instructors based on $A B$ Interaction ( $\mathrm{F}=8.989$; $\mathrm{P}=0.003)$ with $(\alpha=0.05)$. The null Hypothesis for the $A B$ Interaction was rejected. As shown in Table 4.22, the effect size of this significant difference as measured by partial Eta squared was 0.041 , which is a small effect. The estimated marginal means and profile plots revealed an interaction between the two factors (sex and academic field), suggesting that male instructors in scientific were less in their technology expertise than their counterparts in humanities. The pattern is reversed for female instructors. Further details are in (Appendix G).

\section{AC Interaction (Sex \& Experience)}

The results (See Table 4.22) indicated that there was no significant difference in the general technology expertise of instructors based on $A C$ Interaction ( $\mathrm{F}=0.383$; $\mathrm{P}=0.765)$ with $(\alpha=0.05)$. The analysis failed to reject the null Hypothesis for the $A C$ Interaction. As shown in Table 4.22, the effect size of this significant difference as measured by partial Eta squared was 0.005 , which is a small effect. Further details are in (Appendix G). 


\section{$B C$ Interaction (Academic field \& Experience)}

The results (See Table 4.22) indicated that there was a significant difference in the general technology expertise of instructors based on BC Interaction ( $\mathrm{F}=3.540$; $\mathrm{P}=0.016)$ with $(\alpha=0.05)$. The null Hypothesis for the $B C$ Interaction was rejected. As shown in Table (4.22), the effect size of this significant difference as measured by partial Eta squared was 0.048 , which is a small effect. The estimated marginal means and profile plots revealed an interaction between the two factors (academic field and experience) showed the scientific instructors who had 11-15 year experience had more general expertise than those who had either less or more years of experience. As for instructors in humanities, the findings showed that those who hold 6-11 years of experience were more in their technology expertise than others. The humanities and scientific instructors had two interactions. The first one was 5-6 years of experience and the second one 6-11 years of experience. Further details are in (Appendix G) .

\section{$A B C$ Interaction (Sex \& Academic field \& Experience)}

The results (See Table 4.22) indicated that there was no significant difference in the general technology expertise of instructors based on $A B C$ Interaction ( $\mathrm{F}=$ $0.412 ; \mathrm{P}=0.744)$ with $(\alpha=0.05)$. The analysis failed to 
reject the null Hypothesis for the $A B C$ Interaction. As shown in Table (4.22), the effect size of this significant difference as measured by partial Eta squared was 0.006, which is a small effect. Further details are in (Appendix G) .

The 3-way ANOVA did not tell which experience categories were different from others in regard to general technology expertise. To find out where the difference existed, the Scheffe's post hoc test was administered to distinguish the differences among the four categories of experience based on the observed means. Full results of this analysis are available in (Appendix G). The results of Scheffé's method indicate that there was no significant difference in general expertise among the experience categories.

\section{Specific technology expertise}

\section{Main Effect $A$ (Sex: male versus female)}

The results (See Table 4.23) indicated that there was a significant difference in the specific technology expertise of instructors based on their sex $(\mathrm{F}=18.230 ; \mathrm{P}=$ $.000)$ with $(\alpha=0.05)$. The null Hypothesis for the main effect A was rejected. As shown in Table (4.23), the effect 
Table 4.22: 3-way Factorial ANOVA of General Expertise:

Tests of Between-Subjects Effects

Dependent Variable: General Expertise

\begin{tabular}{|l|r|r|r|r|r|r|}
\hline Source & $\begin{array}{c}\text { Type III Sum } \\
\text { of Squares }\end{array}$ & df & Mean Square & \multicolumn{1}{|c|}{$\mathrm{F}$} & \multicolumn{1}{c|}{ Sig. } & $\begin{array}{c}\text { Partial Eta } \\
\text { Squared }\end{array}$ \\
\hline Corrected Model & $29.777^{\mathrm{a}}$ & 15 & 1.985 & 3.201 & .000 & .185 \\
Intercept & 1174.432 & 1 & 1174.432 & 1893.453 & .000 & .900 \\
Sex & 6.342 & 1 & 6.342 & 10.224 & .002 & .046 \\
Afield & 4.188 & 1 & 4.188 & 6.752 & .010 & .031 \\
Experien & 5.727 & 3 & 1.909 & 3.078 & .029 & .042 \\
Sex * Afield & 5.575 & 1 & 5.575 & 8.989 & .003 & .041 \\
Sex * Experien & .713 & 3 & .238 & .383 & .765 & .005 \\
Afield * Experien & 6.588 & 3 & 2.196 & 3.540 & .016 & .048 \\
Sex * Afield * Experien & .767 & 3 & .256 & .412 & .744 & .006 \\
Error & 130.875 & 211 & .620 & & & \\
Total & 1736.000 & 227 & & & & \\
Corrected Total & 160.652 & 226 & & & & \\
\hline
\end{tabular}

a. $\mathrm{R}$ Squared $=.185$ (Adjusted $\mathrm{R}$ Squared $=.127$ )

size of this significant difference as measured by partial Eta squared was 0.080, which is a small effect. Further details are in (Appendix H) .

Main Effect B (Academic field: Scientific versus Humanities)

The results (See Table 4.23) indicated that there was no significant difference in the specific technology expertise of instructors based on their academic field ( $F=$ 2.749; $\mathrm{P}=0.099)$ with $(\alpha=0.05)$. These results failed to reject the null Hypothesis for the main effect B. As shown in Table (4.23), the effect size of this significant difference as measured by partial Eta squared was 0.013, which is a small effect. Further details are in (Appendix H) . 


\section{Main Effect $C$ (experience: four categories)}

The results (See Table 4.23) indicated that there was no significant difference in the specific technology expertise of instructors based on their experience ( $\mathrm{F}=$ 1.447; $\mathrm{P}=0.230)$ with $(\alpha=0.05)$. These results failed to reject the null Hypothesis for the main effect C. As shown in Table (4.23), the effect size of this significant difference as measured by partial Eta squared was 0.020, which is a small effect. Further details are in (Appendix H) .

\section{$A B$ Interaction (Sex \& Academic field)}

The results (See Table 4.23) indicated that there was a significant difference in the specific technology expertise of instructors based on $A B$ Interaction ( $\mathrm{F}=7.216$; $\mathrm{P}=0.008)$ with $(\alpha=0.05)$. The null Hypothesis for the $A B$ Interaction was rejected. As shown in Table (4.23), the effect size of this significant difference as measured by partial Eta squared was 0.033 , which is a small effect. The estimated marginal means and profile plots revealed an interaction between the two factors (sex and academic field), suggesting that male instructors in scientific were less in their specific technology expertise than their counterparts in humanities. The pattern is reversed for female instructors. Further details are in (Appendix H). 


\section{AC Interaction (Sex \& Experience)}

The results (See Table 4.23) indicated that there was no significant difference in the specific technology expertise of instructors based on $A C$ Interaction ( $F=1.138$; $\mathrm{P}=0.335)$ with $(\alpha=0.05)$. These results failed to reject the null Hypothesis for the $A C$ Interaction. As shown in Table (4.23), the effect size of this significant difference as measured by partial Eta squared was 0.016, which is a small effect. Further details are in (Appendix H).

\section{BC Interaction (Academic field\& Experience)}

The results (See Table 4.23) indicated that there was a significant difference in the specific technology expertise of instructors based on $B C$ Interaction $(\mathrm{F}=2.998$; $\mathrm{P}=0.032)$ with $(\alpha=0.05)$. The null Hypothesis for the $B C$ Interaction was rejected. As shown in Table (4.23), the effect size of this significant difference as measured by partial Eta squared was 0.041 , which is a small effect. estimated marginal means and profile plots revealed an interaction between the two factors (academic field and experience) showed the scientific instructors who had 11-15 year experience had more specific expertise than those who had either less or more years of experience. As for instructors in humanities, the findings showed that those who hold 6-10 years of experience were more in their 
specific technology expertise than others. The humanities and scientific instructors had two interactions. The first one was 5-6 years of experience and the second one $10-11$ years of experience. Further details are in (Appendix H).

\section{$A B C$ Interaction (Sex \& Academic field\& Experience)}

The results (See Table 4.23) indicated that there was no significant difference in the specific technology expertise of instructors based on $A B C$ Interaction ( $\mathrm{F}=$ $0.911 ; \mathrm{P}=0.436)$ with $(\alpha=0.05)$. These results failed to reject the null Hypothesis for the $A B C$ Interaction. As shown in Table (4.23), the effect size of this significant difference as measured by partial Eta squared was 0.013, which is a small effect. Further details are in (Appendix H). The 3-way ANOVA did not tell which experience categories were different from others with regard to specific technology expertise. To find out where the difference existed, the Scheffe's post hoc test was administered to distinguish the differences among the four categories of experience based on the observed means. Full results of this analysis are available in (Appendix H) . The results of Scheffé's method indicate that there was no significant difference in specific expertise among the experience categories. 
Table 4.23: 3-way Factorial ANOVA of Specific Expertise:

\section{Tests of Between-Subjects Effects}

Dependent Variable: SPECIFIC EXPERTISE

\begin{tabular}{|l|r|r|r|r|r|r|}
\hline Source & $\begin{array}{c}\text { Type III Sum } \\
\text { of Squares }\end{array}$ & df & Mean Square & \multicolumn{1}{|c|}{$\mathrm{F}$} & \multicolumn{1}{c|}{ Sig. } & $\begin{array}{c}\text { Partial Eta } \\
\text { Squared }\end{array}$ \\
\hline Corrected Model & $41.864^{\mathrm{a}}$ & 15 & 2.791 & 3.384 & .000 & .194 \\
Intercept & 934.122 & 1 & 934.122 & 1132.676 & .000 & .843 \\
Sex & 15.035 & 1 & 15.035 & 18.230 & .000 & .080 \\
Afield & 2.267 & 1 & 2.267 & 2.749 & .099 & .013 \\
Experien & 3.580 & 3 & 1.193 & 1.447 & .230 & .020 \\
Sex * Afield & 5.951 & 1 & 5.951 & 7.216 & .008 & .033 \\
Sex * Experien & 2.816 & 3 & .939 & 1.138 & .335 & .016 \\
Afield * Experien & 7.417 & 3 & 2.472 & 2.998 & .032 & .041 \\
Sex * Afield * Experien & 2.255 & 3 & .752 & .911 & .436 & .013 \\
Error & 174.012 & 211 & .825 & & & \\
Total & 1444.000 & 227 & & & & \\
Corrected Total & 215.877 & 226 & & & & \\
\hline
\end{tabular}

a. $\mathrm{R}$ Squared $=.194$ (Adjusted R Squared $=.137)$

\section{Current Use of e-learning}

Ho2: There is no significant difference in the use of elearning by instructors based on (A) their sex, (B) their academic field, (C) their teaching experience. In symbols

$$
\mu_{\mathrm{oA}}=\mu_{\mathrm{oB}}=\mu_{\mathrm{oC}}=\mu_{\mathrm{o} A \mathrm{~B}}=\mu_{\mathrm{o} A \mathrm{C}}=\mu_{\mathrm{oBC}}=\mu_{\mathrm{o} A \mathrm{BC}}
$$

\section{Main Effect $A$ (Sex: male versus female)}

The results (See Table 4.24) indicated that there was a significant difference in the current use of elearning by instructors based on their sex $(\mathrm{F}=22.594 ; \mathrm{P}=$ $.000)$ with $(\alpha=0.05)$. The null Hypothesis for the main effect $A$ was rejected. The men showed a higher mean value than the women, and this finding shows that men rate themselves as having a higher level of current use. As 
shown in Table 4.24, the effect size of this significant difference as measured by partial Eta squared was 0.097, which is a small effect. Further details are in (Appendix I).

Main Effect $B$ (Academic field: Scientific versus Humanities)

The results (See Table 4.24) indicated that there was no significant difference in the current use of e-learning by instructors based on their sex $(\mathrm{F}=0.137 ; \mathrm{P}=0.712)$ with $(\alpha=0.05)$. These results failed to reject the null Hypothesis for the main effect B. As shown in Table 4.24, the effect size of this significant difference as measured by partial Eta squared was 0.001 , which is a small effect. Further details are in (Appendix I).

Main Effect $C$ (experience: four categories)

The results (See Table 4.24) indicated that there was no significant difference in the current use of e-learning by instructors based on their experience $(\mathrm{F}=2.069 ; \mathrm{P}=$ $0.105)$ with $(\alpha=0.05)$. These results failed to reject the null Hypothesis for the main effect $C$. As shown in Table 4.24, the effect size of this significant difference as measured by partial Eta squared was 0.029 , which is a small effect. Further details are in (Appendix I).

\section{$A B$ Interaction (Sex \& Academic field)}

The results (See Table 4.24) indicated that there was a significant difference in the current use of e-learning 
by instructors based on $A B$ Interaction $(\mathrm{F}=12.802$; $\mathrm{P}=$ $0.000)$ with $(\alpha=0.05)$. The null Hypothesis for the $A B$ Interaction was rejected. As shown in Table 4.24, the effect size of this significant difference as measured by partial Eta squared was 0.057 , which is a small effect. estimated marginal means and profile plots revealed an interaction between the two factors (sex and academic field), suggesting that male instructors in scientific were less in their using of e-learning than their counterparts in humanities. The pattern is reversed for female instructors. Further details are in (Appendix I).

\section{AC Interaction (Sex \& Experience)}

The results (See Table 4.24) indicated that there was no significant difference in the current use of e-learning by instructors based on $A C$ Interaction $(\mathrm{F}=2.342 ; \mathrm{P}=0.074)$ with $(\alpha=0.05)$. These results failed to reject the null Hypothesis for the AC Interaction. As shown in Table 4.24, the effect size of this significant difference as measured by partial Eta squared was 0.032, which is a small effect. Further details are in (Appendix I).

\section{BC Interaction (Academic field\& Experience)}

The results (See Table 4.24) indicated that there was a significant difference in the current use of e-learning by instructors based on BC Interaction ( $\mathrm{F}=3.644 ; \mathrm{P}=0.014)$ 
with $(\alpha=0.05)$. The null Hypothesis for the BC Interaction was rejected. As shown in Table 4.24, the effect size of this significant difference as measured by partial Eta squared was 0.049, which is a small effect. Estimated marginal means and profile plots revealed an interaction between the two factors (academic field and experience) showed the scientific instructors who had 11-15 year experience had more usage of e-learning than those who had either less or more years of experience. As for instructors in humanities, the findings showed that those who hold 6-10 years of experience were more in their specific technology expertise than others. The humanities and scientific instructors had two interactions. The first one was 5-6 years of experience and the second one $10-11$ years of experience. Further details are in (Appendix I).

\section{$A B C$ Interaction (Sex \& Academic field\& Experience)}

The results (See Table 4.24) indicated that there was no significant difference in the current use of e-learning by instructors based on $A B C$ Interaction $(\mathrm{F}=2.603$; $\mathrm{P}=$ $0.053)$ with $(\alpha=0.05)$. These results failed to reject the null Hypothesis for the $A B C$ Interaction was failed to reject. As shown in Table 4.24, the effect size of this significant difference as measured by partial Eta squared 
was 0.036, which is a small effect. Further details are in (Appendix I) .

The 3-way ANOVA did not tell which experience categories were different from others with regard to current use of e-learning. To find out where the difference existed, the Scheffe's post hoc test was administered to distinguish the differences among the four categories of experience based on the observed means. Full results of this analysis are available in (Appendix I). The results of Scheffé's method indicate that there was no significant difference in current use of e-learning among the experience categories.

Table 4.24: 3-way Factorial ANOVA of Current Use e-learning:

Tests of Between-Subjects Effects

Dependent Variable: CURRENT USE

\begin{tabular}{|l|r|r|r|r|r|r|}
\hline Source & $\begin{array}{c}\text { Type III Sum } \\
\text { of Squares }\end{array}$ & df & Mean Square & \multicolumn{1}{c|}{ F } & \multicolumn{1}{c|}{ Sig. } & $\begin{array}{c}\text { Partial Eta } \\
\text { Squared }\end{array}$ \\
\hline Corrected Model & $22.024^{\mathrm{a}}$ & 15 & 1.468 & 3.329 & .000 & .191 \\
Intercept & 364.392 & 1 & 364.392 & 826.285 & .000 & .797 \\
Sex & 9.964 & 1 & 9.964 & 22.594 & .000 & .097 \\
Afield & .060 & 1 & .060 & .137 & .712 & .001 \\
Experien & 2.738 & 3 & .913 & 2.069 & .105 & .029 \\
Sex *Afield & 5.646 & 1 & 5.646 & 12.802 & .000 & .057 \\
Sex * Experien & 3.098 & 3 & 1.033 & 2.342 & .074 & .032 \\
Afield * Experien & 4.821 & 3 & 1.607 & 3.644 & .014 & .049 \\
Sex *Afield * Experien & 3.444 & 3 & 1.148 & 2.603 & .053 & .036 \\
Error & 93.051 & 211 & .441 & & & \\
Total & 569.000 & 227 & & & & \\
Corrected Total & 115.075 & 226 & & & & \\
\hline
\end{tabular}

a. $\mathrm{R}$ Squared $=.191$ (Adjusted $\mathrm{R}$ Squared $=.134)$ 


\section{Motivational factors}

Ho3: There is no significant difference in motivational factors among instructors based on (A) their sex, (B) their academic field, and (C) their teaching experience. In symbols,

$\mu_{\mathrm{oA}}=\mu_{\mathrm{oB}}=\mu_{\mathrm{oC}}=\mu_{\mathrm{o} A \mathrm{~B}}=\mu_{\mathrm{oAC}}=\mu_{\mathrm{oBC}}=\mu_{\mathrm{o} \mathrm{ABC}}$

\section{Main Effect $A$ (Sex: male versus female)}

The results (See Table 4.25) indicated that there was no significant difference in motivational factors among instructors based on their sex $(\mathrm{F}=0.965 ; \mathrm{P}=.327)$ with $(\alpha$ $=0.05)$. These results failed to reject the null Hypothesis for the main effect A. As shown in Table 4.25, the effect size of this significant difference as measured by partial Eta squared was 0.005, which is a small effect. Further details are in (Appendix J).

Main Effect B (Academic field: Scientific versus Humanities)

The results (See Table 4.25) indicated that there was no significant difference in motivational factors among instructors based on their sex $(\mathrm{F}=1.753 ; \mathrm{P}=0.187)$ with $(\alpha$ $=0.05)$. These results failed to reject the null Hypothesis for the main effect B. As shown in Table 4.25, the effect size of this significant difference as measured by partial Eta squared was 0.008 , which is a small effect. Further details are in (Appendix $J$ ) . 


\section{Main Effect C (experience: four categories)}

The results (See Table 4.25) indicated that there was no significant difference in motivational factors among instructors based on their experience ( $\mathrm{F}=0.435 ; \mathrm{P}=0.728)$ with $(\alpha=0.05)$. These results failed to reject the null Hypothesis for the main effect C. As shown in Table 4.25, the effect size of this significant difference as measured by partial Eta squared was 0.006 , which is a small effect. Further details are in (Appendix J).

\section{$A B$ Interaction (Sex \& Academic field)}

The results (See Table 4.25) indicated that there was no significant difference in motivational factors among instructors based on $A B$ Interaction $(\mathrm{F}=1.007 ; \mathrm{P}=0.317)$ with $(\alpha=0.05)$. These results failed to reject the null Hypothesis for the $A B$ Interaction. As shown in Table 4.25, the effect size of this significant difference as measured by partial Eta squared was 0.005 , which is a small effect. Further details are in (Appendix J).

\section{AC Interaction (Sex \& Experience)}

The results (See Table 4.25) indicated that there was no significant difference in motivational factors among instructors based on $A C$ Interaction $(\mathrm{F}=1.150 ; \mathrm{P}=0.330)$ with $(\alpha=0.05)$. These results failed to reject the null Hypothesis for the AC Interaction. As shown in Table 4.25, 
the effect size of this significant difference as measured by partial Eta squared was 0.016 , which is a small effect. Further details are in (Appendix J).

\section{BC Interaction (Academic field\& Experience)}

The results (See Table 4.25) indicated that there was no significant difference in motivational factors among instructors based on $B C$ Interaction $(\mathrm{F}=1.065 ; \mathrm{P}=0.365)$ with $(\alpha=0.05)$. These results failed to reject the null Hypothesis for the BC Interaction. As shown in Table 4.25, the effect size of this significant difference as measured by partial Eta squared was 0.015 , which is a small effect. Further details are in (Appendix J).

\section{$A B C$ Interaction (Sex \& Academic field\& Experience)}

The results (See Table 4.25) indicated that there was no significant difference in motivational factors among instructors based on $A B C$ Interaction $(\mathrm{F}=0.053 ; \mathrm{P}=0.984)$ with $(\alpha=0.05)$. These results failed to reject the null Hypothesis for the ABC Interaction. As shown in Table 4.25, the effect size of this significant difference as measured by partial Eta squared was 0.001 , which is a small effect. Further details are in (Appendix $J$ ).

The 3-way ANOVA did not tell which experience categories were different from others with regard to factorial motivations. To find out where the difference 
existed, the Scheffe's post hoc test was administered to distinguish the differences among the four categories of experience based on the observed means. Full results of this analysis are available in (Appendix J). The results of Scheffé's method indicate that there was no significant difference in factorial motivations among the experience categories.

Table 4.22 : 3-way Factorial ANOVA of Motivational Factors:

\section{Tests of Between-Subjects Effects}

Dependent Variable: MOTIVATION

\begin{tabular}{|l|r|r|r|r|r|r|}
\hline Source & $\begin{array}{c}\text { Type III Sum } \\
\text { of Squares }\end{array}$ & df & Mean Square & \multicolumn{1}{c|}{ F } & \multicolumn{1}{c|}{ Sig. } & $\begin{array}{c}\text { Partial Eta } \\
\text { Squared }\end{array}$ \\
\hline Corrected Model & $10.314^{\mathrm{a}}$ & 15 & .688 & .826 & .648 & .055 \\
Intercept & 1569.724 & 1 & 1569.724 & 1885.433 & .000 & .899 \\
Sex & .803 & 1 & .803 & .965 & .327 & .005 \\
Afield & 1.460 & 1 & 1.460 & 1.753 & .187 & .008 \\
Experien & 1.086 & 3 & .362 & .435 & .728 & .006 \\
Sex * Afield & .838 & 1 & .838 & 1.007 & .317 & .005 \\
Sex * Experien & 2.873 & 3 & .958 & 1.150 & .330 & .016 \\
Afield * Experien & 2.660 & 3 & .887 & 1.065 & .365 & .015 \\
Sex * Afield * Experien & .133 & 3 & .044 & .053 & .984 & .001 \\
Error & 175.669 & 211 & .833 & & & \\
Total & 2217.000 & 227 & & & & \\
Corrected Total & 185.982 & 226 & & & & \\
\hline
\end{tabular}

a. $\mathrm{R}$ Squared $=.055$ (Adjusted R Squared $=-.012$ )

\section{Barrier Factors}

Ho4: There is no significant difference in barrier factors among instructors based on (A) their sex, (B) their academic field, and (C) their teaching experience. In symbols,

$\mu_{\mathrm{oA}}=\mu_{\mathrm{oB}}=\mu_{\mathrm{oC}}=\mu_{\mathrm{o} A \mathrm{~B}}=\mu_{\mathrm{oAC}}=\mu_{\mathrm{oBC}}=\mu_{\mathrm{o} \mathrm{ABC}}$ 


\section{Main Effect $A$ (Sex: male versus female)}

The results (See Table 4.26) indicated that there was a significant difference in barrier factors among instructors based on their sex $(F=5.447 ; P=.021)$ with $(\alpha$ $=0.05)$. The null Hypothesis for the main effect $A$ was rejected. As shown in Table 4.26, the effect size of this significant difference as measured by partial Eta squared was 0.025, which is a small effect. Further details are in (Appendix K) .

\section{Main Effect B (Academic field: Scientific versus Humanities)}

The results (See Table 4.26) indicated that there was no significant difference in barrier factors among instructors based on their sex $(\mathrm{F}=2.959 ; \mathrm{P}=0.087)$ with $(\alpha$ $=0.05)$. These results failed to reject the null Hypothesis for the main effect B. As shown in Table 4.26, the effect size of this significant difference as measured by partial Eta squared was 0.014, which is a small effect. Further details are in (Appendix $\mathrm{K}$ ).

\section{Main Effect $C$ (experience: four categories)}

The results (See Table 4.26) indicated that there was no significant difference in barrier factors among instructors based on their experience $(F=0.727 ; \quad P=0.537)$ with $(\alpha=0.05)$. These results failed to reject the null Hypothesis for the main effect C. As shown in Table 4.26, 
the effect size of this significant difference as measured by partial Eta squared was 0.010, which is a small effect. Further details are in (Appendix K).

\section{$A B$ Interaction (Sex \& Academic field)}

The results (See Table 4.26) indicated that there was no significant difference in barrier factors among instructors based on $A B$ Interaction $(\mathrm{F}=1.143 ; \mathrm{P}=0.286)$ with $(\alpha=0.05)$. These results failed to reject the null Hypothesis for the $A B$ Interaction. As shown in Table 4.26, the effect size of this significant difference as measured by partial Eta squared was 0.005 , which is a small effect. Further details are in (Appendix K).

\section{AC Interaction (Sex \& Experience)}

The results (See Table 4.26) indicated that there was no significant difference in barrier factors among instructors based on $A C$ Interaction $(\mathrm{F}=1.481 ; \mathrm{P}=0.221)$ with $(\alpha=0.05)$. These results failed to reject the null Hypothesis for the AC Interaction. As shown in Table 4.26, the effect size of this significant difference as measured by partial Eta squared was 0.021 , which is a small effect. Further details are in (Appendix K).

\section{BC Interaction (Academic field\& Experience)}

The results (See Table 4.26) indicated that there was no significant difference in barrier factors among 
instructors based on $B C$ Interaction $(\mathrm{F}=0.125 ; \mathrm{P}=0.946)$ with $(\alpha=0.05)$. These results failed to reject the null Hypothesis for the BC Interaction. As shown in Table 4.26, the effect size of this significant difference as measured by partial Eta squared was 0.002 , which is a small effect. Further details are in (Appendix K).

\section{$A B C$ Interaction (Sex \& Academic field\& Experience)}

The results (See Table 4.26) indicated that there was no significant difference in barrier factors among instructors based on $A B C$ Interaction $(\mathrm{F}=1.273 ; \mathrm{P}=0.284)$ with $(\alpha=0.05)$. These results failed to reject the null Hypothesis for the ABC Interaction. As shown in Table 4.26, the effect size of this significant difference as measured by partial Eta squared was 0.018 , which is a small effect. Further details are in (Appendix K).

The 3-way ANOVA did not tell which experience categories were different from others with regard to barriers. To find out where the difference existed, the Scheffe's post hoc test was administered to distinguish the differences among the four categories of experience based on the observed means. Full results of this analysis are available in (Appendix $K$ ). The results of Scheffé's method indicate that there was no significant difference in barriers among the experience categories. 
Table 4.23: 3-way Factorial ANOVA of Factors Impeding

Tests of Between-Subjects Effects

Dependent Variable: BARRIERS

\begin{tabular}{|l|r|r|r|r|r|r|}
\hline Source & $\begin{array}{c}\text { Type III Sum } \\
\text { of Squares }\end{array}$ & df & Mean Square & \multicolumn{1}{c|}{ F } & \multicolumn{1}{c|}{ Sig. } & $\begin{array}{c}\text { Partial Eta } \\
\text { Squared }\end{array}$ \\
\hline Corrected Model & $14.595^{\mathrm{a}}$ & 15 & .973 & 1.416 & .142 & .091 \\
Intercept & 1276.858 & 1 & 1276.858 & 1857.599 & .000 & .898 \\
Sex & 3.744 & 1 & 3.744 & 5.447 & .021 & .025 \\
Afield & 2.034 & 1 & 2.034 & 2.959 & .087 & .014 \\
Experien & 1.498 & 3 & .499 & .727 & .537 & .010 \\
Sex * Afield & .786 & 1 & .786 & 1.143 & .286 & .005 \\
Sex * Experien & 3.054 & 3 & 1.018 & 1.481 & .221 & .021 \\
Afield * Experien & .257 & 3 & .086 & .125 & .946 & .002 \\
Sex *Afield * Experien & 2.626 & 3 & .875 & 1.273 & .284 & .018 \\
Error & 145.035 & 211 & .687 & & & \\
Total & 1815.000 & 227 & & & & \\
Corrected Total & 159.630 & 226 & & & & \\
\hline
\end{tabular}

a. $\mathrm{R}$ Squared $=.091$ (Adjusted $\mathrm{R}$ Squared $=.027$ )

\section{Summary of the findings:}

This study includes two statistical techniques:
descriptive and inferential statistics. These statistical
results highlight the sample characteristics and
significant findings of this study. The sample
characteristics show that this study contained 227
participants: a majority of participants based on sex were
female (55.9\%), based on academic field were from the
academic field of science (59.5\%), and based on experience
had more than 15 years of teaching experience (40.5\%).
The following characteristics show the main
descriptive features of the four dependent variables
(technological expertise, e-learning usage, motivational


factors, and barriers). Technological expertise is divided here into two categories (general and specific expertise). With regard to general expertise, this study found that the majority of participants had a positive sense of technological expertise and categorized themselves as "proficient" (51.1\%). An analysis of the three highest (using a computer to find resources from the university library, using a word processor to create documents, and using presentation software) and three lowest (website design, use of electronic bulletin board, use video conferencing) items of specific expertise shows that the participants had a positive sense of technological expertise in traditional technology usage but did not have the same sense of expertise regarding advanced technology usage.

For current use, this study also found that the majority of participants (63.4\%) "seldom" use technology, and the use of technology followed the same pattern of having the three highest items (use of internet research and searches, use of computer software for handouts or lecture notes, and use of presentation software in the classroom) based on traditional technology usage and the three lowest items (use of electronic conferencing; use of personally designed web-based lectures, notes, or tutorials 
(see Table 4.24); and use of personally designed web-based tests or quizzes) based on advanced technology usage.

Overall, the frequency of the participant responses for the motivational factors was positive (78.5\% chose "encouraging" or "highly encouraging"). The overall mean score for motivational factors was 2.99 out of 4.00 and supports this finding. The motivational factors were also defined as being extrinsic or intrinsic. The top two motivational factors (see Table 4.25) were defined as intrinsic factors in this study. Thus, this study finds that motivational factors are influential, and the most influential motivational factors are intrinsic.

Similarly, the frequency of the participant responses for the barrier factors was positive (64.7\% chose "some barriers" or "many barriers"). The overall mean score for barrier factors was 2.70 out of 4.00 and supports this finding. Like the motivational factors, the barrier factors were also defined as being extrinsic or intrinsic. However, unlike the motivational factors, all of the top barrier factors (see Table 4.26) were defined as extrinsic factors in this study. Thus, this study finds that barrier factors are influential, and the most influential barrier factors are extrinsic. 
The factor analysis was conducted at the beginning to investigate and explore the variables and to improve the questionnaires of the research. The results of the factor analysis were coincided with the findings of the descriptive technique.

There is a significant difference in the general expertise of instructors based on all three independent variables as shown by the main effect: $\operatorname{sex}(\mathrm{F}=10.244 ; \mathrm{P}=$ 0.002), academic field $(\mathrm{F}=6.752 ; \mathrm{P}=0.010)$ and experience $(\mathrm{F}=3.078 ; \mathrm{P}=0.029)$. The interaction of the factors of sex and academic field and the factors of academic field and experience also showed a significant difference in general expertise: sex and academic field (F $=8.989 ; \mathrm{P}=0.003)$ and academic field and experience $(\mathrm{F}=$ 3.540; $\mathrm{P}=0.016)$. The other interactions did not show a significant difference in general expertise.

For specific expertise of instructors based on the main effect of the three independent variables, only sex showed a significant difference: $F=18.230 ; P=0.000$. In addition, only two interactions showed a significant difference in specific expertise: the interaction of sex and academic field $(F=7.216 ; \quad P=0.008)$ and the interaction of academic field and experience $(\mathrm{F}=2.998 ; \mathrm{P}$ 
$=0.032)$. The other interactions did not show a significant difference in specific expertise.

Like specific expertise, the only independent variable that showed a significant difference in current use was sex $(F=22.594 ; P=0.000)$. In addition, only two interactions showed a significant difference in current use: the interaction of sex and academic field $(\mathrm{F}=12.802 ; \mathrm{P}=$ 0.000 ) and the interaction of academic field and experience $(\mathrm{F}=3.644 ; \mathrm{P}=0.014)$. The other interactions did not show a significant difference in current use.

For motivational factors, no significant differences exist in terms of the main effects or the interactions. For barrier factors, there is only a significant difference in terms of the main effect of sex $(F=5.447$; $P$ $=0.021)$. 


\section{CHAPTER ( $V$ )}

\section{Summary, Conclusions, and Recommendations Summary of the study}

The purpose of the study was to determine whether significant differences exist among instructors from King Abdulaziz University's (KAU) Humanities and Scientific Colleges concerning their perceived levels of expertise and current use of e-learning technologies as part of their teaching. In addition, the interactions between the independent factors of sex, academic field, and teaching experience were analyzed in relation to their effect on the dependent factors. The results of this study are examined below, and recommendations are suggested for future applications and research.

\section{Research Design and Procedure}

Three techniques of statistics, including factor analysis, descriptive and inferential statistics, were used to answer the research questions. For the first set of research questions, descriptive statistics were used: specifically, frequencies, means, percentages, and standard deviation. Inferential statistics were used to answer the second set of research questions: a 3-way Factoral ANOVA $(2 \times 2 \times 4)$ and a Scheffe's post hoc test were conducted. This 
study had four dependent variables: 1) expertise of technology, 2) current use of e-learning, 3) motivational factors, and 4) barriers. There were three independent variables in the study: (A) sex (male and female), (B) academic field (scientific and humanities), and (C) years of teaching experience $(0-5,6-10,11-15$, and 15+).

The population of the study consisted of roughly 2000 instructors from the King Abdulaziz University (KAU) in Saudi Arabia during the academic year of 2007-2008. The participation in the study was voluntary, and the survey questionnaire was distributed to a randomly selected sample of professors in the science and humanities colleges at KAU. The participants totaled 227 from the KAU Jeddah men's and women's campus. Male participants represent (44.1\%) and female participant represent (55.9\%); a majority of participants based on academic field were from the academic field of science: 59.5\% of the sample size of the study.

\section{Conclusions}

This section presents the findings of the study and a discussion of those findings. Based on the findings of the descriptive and inferential statistical analyses, the effect of independent instructor characteristics on dependent factors of e-learning was examined. 
The following characteristics show the main descriptive features of the four dependent variables (technological expertise, e-learning usage, motivational factors, and barriers). Technological expertise was divided into two categories (general and specific expertise). With regard to general expertise, this study found that the majority of participants had a positive sense of technological expertise and categorized themselves as "proficient" (51.1\%). An analysis of the three highest areas of specific expertise (using a computer to find resources from the university library, using a word processor to create documents, and using presentation software) and three lowest areas of specific expertise (website design, use of electronic bulletin board, use video conferencing) revealed that the participants had a positive sense of technological expertise in traditional technology usage but did not have the same sense of expertise regarding advanced technology usage. These findings are compatible with findings from other studies that targeted instructors' technological expertise ( (Lane \& Yamashiro, 2006); Arabasz et al., 2003).

There were significant differences in the general expertise of instructors based on all three independent variables as shown by the main effect: sex $(\mathrm{F}=10.244 ; \mathrm{P}=$ 
$0.002)$, academic field $(\mathrm{F}=6.752 ; \mathrm{P}=0.010)$ and experience $(F=3.078 ; P=0.029)$. The interaction of the factors of sex and academic field and the factors of academic field and experience also showed a significant difference in general expertise: sex and academic field ( $F$ $=8.989 ; \mathrm{P}=0.003)$ and academic field and experience $(\mathrm{F}=$ 3.540; $\mathrm{P}=0.016)$. The $(\mathrm{AxBxC})$ interactions did not show $a$ significant difference in general expertise. This finding is in accordance with previous studies that have shown that males report a higher overall level of expertise(Lane \& Yamashiro, 2006).

Regarding the specific expertise of instructors based on the main effect of the three independent variables, only sex showed a significant difference: $F=18.230 ; P=0.000$. In addition, only two interactions showed a significant difference in specific expertise: the interaction of sex and academic field $(\mathrm{F}=7.216 ; \mathrm{P}=0.008)$ and the interaction of academic field and experience $(\mathrm{F}=2.998 ; \mathrm{P}$ $=0.032)$. The other interactions did not show a significant difference in specific expertise. These findings agree with earlier studies that concerned areas of specific expertise and showed that males indicate a higher specific levels of expertise (Lane \& Yamashiro, 2006). 
Regarding current use, this study also found that the majority of participants (63.4\%) "seldom" use technology, and the use of technology followed the same pattern of having the three highest items (use of internet research and searches, use of computer software for handouts or lecture notes, and use of presentation software in the classroom) based on traditional technology usage and the three lowest items (use of electronic conferencing; use of personally designed web-based lectures, notes, or tutorials; and use of personally designed web-based tests or quizzes) based on advanced technology usage. The higher use and expertise of the instructors with traditional technology rather than advanced technology reveals that advanced technologies have not yet become commonplace in elearning.

Like specific expertise, the only independent variable that showed a significant difference in current use was sex $(F=22.594 ; P=0.000)$. In addition, only two interactions showed a significant difference in current use: the interaction of sex and academic field $(\mathrm{F}=12.802 ; \mathrm{P}=$ $0.000)$ and the interaction of academic field and experience $(F=3.644 ; P=0.014)$. The other interactions did not show a significant difference in current use. The findings related to sex are compatible with findings from other 
studies that showed the effect of sex on an instructors' use of e-learning (Betts 1998; Lane \& Yamashiro, 2006; Russell \& Bradley, 1997; Yuen \& Ma, 2002; So \& Swatman, $2006)$

Overall, the frequency of the participant responses for the motivational factors was positive $(78.5 \%$ chose "encouraging" or "highly encouraging"). The overall mean score for motivational factors was (2.99) out of (4.00) and supports this finding. The motivational factors were also defined as being extrinsic or intrinsic. The top three motivational factors include 1) personal computer skills, 2) the opportunity to improve teaching, and 3) classroom technology infrastructure (e.g., wiring, computers, or projectors), and the lower three motivational factors include 1) Support and encouragement from peers, 2) Opportunity to reach new audiences that can not attend classes on campus, and 3) Credit toward promotion and tenure. In addition, motivational factors showed that no statistically significant differences exist in terms of the main effects or the interactions with three independent variables. These factors were also analyzed in terms of being extrinsic or intrinsic, and the top two motivational factors were found to be intrinsic. These results show that intrinsic motivational factors are more important than 
extrinsic factors in encouraging an instructor to adopt and use e-learning. Although intrinsic factors were the most important, extrinsic factors were also important and should not be discounted. In order to provide proper motivation for instructors to use e-learning, they should be encouraged with intrinsic as well as extrinsic factors. This finding is in accordance with the findings of the literature review in this study, e.g. (Taylor \& White, 1991; Lonsdale, 1993; Betts, 1998; Maguire 2005).

Similarly, the frequency of the participant responses for the barrier factors was positive (64.7\% chose "some barriers" or "many barriers"). The overall mean score for barrier factors was 2.70 out of 4.00 and supports this finding. Like the motivational factors, the barrier factors were also defined as being extrinsic or intrinsic. However, unlike the motivational factors, all of the top barrier factors (see Table 4.11) were defined as extrinsic factors in this study. Thus, this study finds that barrier factors are influential, and the most influential barrier factors are extrinsic. For barrier factors, there is only a significant difference in terms of the main effect of sex $(F=5.447 ; P=0.021)$. These findings are compatible with findings from other studies (Meyers, 2000b; Betts, 1998). 


\section{Recommendations}

In order for e-learning to be successful in higher education, e-learning technologies must be made more meaningful and integrative in the teaching and learning conducted by instructors at King AbdulAziz University. This study reveals several areas of concern, identified by instructors, regarding e-learning. The following sections suggest recommendations for applications and future research to understand and use these problem areas to enhance the use of e-learning by instructors.

\section{Recommendations for KAU Administration}

This study makes three recommendations for KAU: 1) Improve the technological infrastructure. 2) Motivate instructors by offering acknowledgement for e-learning use. 3) Apply these changes to the entire university system. These three recommendations are discussed in further detail below

The first recommendation of this study for improving the implementation of e-learning at KAU involves the most important barrier factor as identified by the instructors: technological infrastructure. The technological infrastructure consists of the resources (human and technical) that exist for e-learning in the university. With a proper technological infrastructure, the other two 
to barriers (lack of student access and lack of technical support) will also be solved. In order to correct this problem, the university should provide the instructors with proper access and availability to the appropriate technology and resource staff to facilitate e-learning. Having the appropriate technology and resource staff available can encourage students and instructors with experience in e-technology or a desire to use e-technology to consider this university.

E-learning is an interrelated process, and all of the various aspects of e-learning (expertise, motivation, use, etc...) influence one another. By improving the barriers that are identified by the instructors, the administration may also improve other areas of concern. As identified by the instructors, technological infrastructure is a weakness at KAU, and this problem may have caused other problems that were observed in the results of this study. For example, the lack of a proper infrastructure may have been the cause of the reported lack of use by the instructors. Perhaps with a better infrastructure, the instructors would show a higher level of use for e-learning.

Due to the fact that most of the barriers were extrinsic, these problems can be solved with environmental improvements such as the improvement of the technological 
infrastructure. Some of the motivational factors were also extrinsic, and the factors that were identified (such as classroom technology) would all be enhanced with improved technological infrastructure. However, many of the important motivational factors were intrinsic.

The second recommendation of this study is that universities can focus on these motivational factors to encourage instructors to at least try new technologies in the classroom. For instance, universities could provide awards or acknowledgements for outstanding e-learning integration or consider e-learning use when evaluating the instructors. As this study mentions earlier in this section, e-learning is an interrelated process, and administrators should consider both extrinsic and intrinsic factors as they integrate e-learning into university programs.

The third and final recommendation of this study is these changes need to be applied to the entire university system. Due to the fact that this study shows an effect of sex and academic field on e-learning expertise and use (in the case of sex), the university should make an effort to improve e-learning integration for the entire system without focusing on any specific group or program. Thus, this study recommends that to improve the problem areas in 
e-learning identified by the instructors, administrators should improve both extrinsic and intrinsic factors for the entire system

\section{Recommendation for Future Research}

This study offers opportunities and pathways for future research to more fully examine other variables and factors that may contribute to or influence the use, expertise, motivational factors, and barriers of instructors to e-learning. First, this research presented four limitations as mentioned in Chapter 1; future research should consider these limitations as points of study to determine whether they are creating confounding effects in this experiment.

In addition, this study was conducted quantitatively, and perhaps a qualitative study would provide more insight into the findings expressed here. A qualitative study could include interviews with the instructors or a case study of KAU with a focus on e-learning. This type of a study could provide further insight into the problem of e-learning use in the university and may be able to help further focus future research.

This study only observes the areas where an effect occurred, but this study does not evaluate the cause of 
those effects. For example, sex and academic field showed a significant difference with expertise, and sex showed a significant difference with use. It is the recommendation of this study that future studies focus on the causes of these discrepancies in order to find more solutions for solving these problems with future e-learning systems.

The final recommendation for future research provided by this study concerns government and administrators. This study recommends that government and university administrators be studied to determine their readiness for and attitudes toward e-learning. These two variables are important when considering the implementation of e-learning into the educational system, and the results of this research may identify causes for the problems observed with the instructors. 


\section{References}

Arabasz, P., Pirani, J.A., \& Fawcett, D. (2003). Supporting e-learning in higher education: Research study for the Educause Center for Applied Research, v.3,.Boulder, Colo: Educause Center for Applied Research.

Armstrong, L. (2000). Distance learning:An academic leader's perspective on a disruptive product. Change, $32(6), 20-27$.

Barnett, R. (1990). The idea of higher education: Society for Research into Higher Education and Open University Press.

Berge, Z. L. (1998). Barriers to online teaching in postsecondary institutions: Can policy changes fix it? Online Journal of Distance Learning Administration, 1(2), Retrieved July 5,2007, from http://nurs. westga.edu / distance /ojdla/ summer2012 /berge2012.pdf.

Berry, J. (2000). Traditional training fades in favor of elearning. InternetWeek(800), 33.

Broadbent, B. (2000). Staying afloat in the e-learning sea. In Training \& development (Vol. 54, pp. 98): American Society for Training \& Development. 
Choi, D. H., Kim, J., \& Kim, S. H. (2007). Erp training with a web-based electronic learning system: The flow theory perspective. International Journal of HumanComputer Studies, $65(3), 223$.

Conole, G., Dyke, M., Oliver, M., \& Seale, J. (2004). Mapping pedagogy and tools for effective learning design. Computers \& Education, 43(1/2), 17.

Cook, L. S., Fry, P. G., Konopak, B., \& Moore, C. (2002). Problems in developing a constructivist approach to teaching: One teacher's transition from teacher preparation to teaching. Elementary School Journal, $102(5), 389$.

Cooper, R. B., \& Zmud, R. W. (1990). Information technolody implementation research:A teacnological diffusion approach. Management Science, 36(2), 123.

Cuban, L. (1986). Teachers and machines the classroom use of technology since 1920: New York: Teachers College Press.

Davis, A. (2004). Developing an infrastructure for online learning: In T. Anderson and F. Elloumi (Eds), Theory and Practice of Online Learning (pp. 97-114). Athabasca University: Canada. Retrieved May 15, 2007, from http: //cde.athabascau.ca/online book/index.html. 
Dooley, K. E., \& Murphrey, T. P. (2000). How the perspectives of administrators, faculty, and support units impact the rate of distance education adoption. Online Journal of Distance Learning Administration, 3(4).

Dowling, C. \& Lai, K. (2003). Information and communication technology and the teacher of future. Melbourne, Australia: Kluwer Academic publishers.

Espinosa, E. D., Noguez, J., Benes, B., \& Bueno, A. (2005). Polizied e-learning using contract management. Computers \& Education, $45(1), 75$.

Fielder, S. K. (2003). Faculty attitudes toward student satisfaction with online courses. Western Governors University.

Flowers, S., \& Reeve, S. (2004). From high level clarity to ground level confusion: Exactly where do it-mediated education policies fit? In r. Ottewill, l. Borredon, 1. Falque, b. Macfarlane, \& a.Wall (eds.). Educational innovation in economics and business, 8, Dordrecht, The Netherlands: Kluwer.

Foster, K. R., \& Cass, S. A. (2002). Are classroom computers worthwhile? IEEE Spectrum, 39(2), 60. Fraenkel, J. R., \& Wallen, N. (2000). How to design and evaluate research in education. (5nd ed). New York: McGraw-Hill. 
Fulk, J. (1 993). Social construction of communication technology. Academy of Management Journal, 36 , $921-950$

Fulk, J., Schmitz, J., Steinfield, C. W., Fulk, J., \& Steinfield, C. W. (1990). A social influence model of technology use. In organizations and communication technology. (pp. 117): Sage Publications, Inc.

Gardiner, L. F. (1997). Producing dramatic increase in student learning: Can we do it? National Teaching and Learning Forum, 6(2).

Graham, G. (2004). E-learning: A philosophical enquiry. Emerald.

Green, K. C. (1997). Think twice and businesslike about distance education. AAHE Bulletin: 3-5.

Hara, N., \& Kling, R. (1999). Students' frustrations with web-based distance education courses. 4(12), Retrieved June 2, 2007 from http://firstmonday.org/ issues/ issue2004_2012/hara/index.htnml.

Heath, M. (1997). Instructional design models for emerging technologies. In Proceedings of the World Conference on Technolgy and Teacher Education(SITE97), pp.459463. 
Henderson, A. J. (2003). The e-learning question and answer book: A survival guide for trainers and business managers.

Hicks, S. (2000). Evaluating e-learning. Training \& Development, $54(12), 75$.

IBM. (2004). Ibm's learning transformation story. IBM Learning Solutions, Retrieved Agust 18,2007, from http://www-2304.ibm.com/jct03001c/services/learning / solutions/pdfs/learning_transformation.pdf.

Islam, K. A. (2002). Is e-learning floundering? e-learning, $3(5), 22$.

Ishtaiwa,F.(2006) Factors influencing faculty participation in e-Learning: The case of Jordan. University of Washington, Washington, D.C., Virginia.

Jarvis, P. (1987). Adult learning in a social context. London: Croom Helm).

Jiang, M., Parent, S., \& Eastmond, D. (2006). Effectiveness of web-based learning opportunities in a competencybased program. International Journal on E-Learning, $5(3), \quad 353-360$.

Jones, D. (2000). From the president. NCHEMS, 16 (Retrieved July 142007 from http://www.nchems.org/news /NCHEMS $\div 20$ News $\% 20$ Dec2000.pdf). 
Kolb, D. A. (1984). Experiential learning: Experience as the source of learning and development / david a. Kolb experiential learning: Experience as the source of learning and development / david a. Kolb. In: Englewood Cliffs, N.J.: Prentice-Hall, c1984.

Kuljis, J., \& Lees. (2002). Lessons from industry in the design of virtual collaborative learning environments. ITI. Proceedings of the 24th International Conference on Information Technology Interfaces (IEEE Cat. No. $02 \mathrm{EX} 534), \quad 1,31-36$

Lane, C., \& Yamashiro, G. (2006). Report on the 2005 instracturs and student surveys: University of Washington

Laurillard, D. (2002). Rethinking university teaching: A framework for the effective use of educational technology,2nd edition: London and New York, Rourledge /Falmer.

Levine, A., \& Sun, J. C. (2002). Barriers to distance education.Distributed education: Challenges, choices, and a new environment, sixth in a series: American Council on Education, Washington D. C. Educause, Washington D. C.

Lonsdale, A. (1993). Changes in incentives, rewards and sanctions. Higher Education Management, 5(2), 223. 
Maguire, L. (2005). Faculty participation in online distance education: Barriers and motivators. Online Journal of Distance Learning Administration, VIII(1), Retrieved Agust 12,2007, from http://www.westga.edu / ristance/rockwel12024.html.

Mantyla, K. (2001). Blending e-learning: The power is in the mix: ASTD.

Maxey, R. J. (2002). Effectiveness of interactive video instruction on skill acquisition compared to instructor-led instruction in an automotive air conditioning course. Southern Illinois University, Carbondale.

McGlothlin, W. J. (1960). Patterns of professional education. New York: Putnam.

McNaught, C., \& Oliver, M. (2003). Identifying the complexity of factors in the sharing and reuse of resources: Chapter 16. Journal of Interactive Media in Education, $2003(1)$.

Medlin,B.D.(2001) The factos that may influence a faculty member's decision to adopt electronic technologies in instraction.Virginia Polytechnic Institute and Stat University, Blacksburg, Virginia. 
Meyers, D. R. (2000a). The factors that motivate and impede computer use by teachers. University of La Verne, La Verne, California.

Murray, T. (1999). Authoring intelligent tutoring systems: An analysis of the state of the art. International Journal of Artificial Intelligence in Education, (10), $98-129$.

National Education Association, W. D. C. (2000). A survey of traditional and distance learning higher education members .

Oates, K., \& Rengarajan, R. (2002). Synching up with virtual classrooms. E-learning. T+D, 56(9), 57. Oliver, M., MacBean, J., Conole, G., \& Harvey, J. (2002). Using a toolkit to support the evaluation of learning. Journal of Computer-Assisted Learning, 18(2), 199-208. Parisot, A. H. (1997). Distance education as a catalyst for changing teaching in the community college: Implications for institutional policy. New Directions for Community Colleges, 25(3), pp.5-13.

Postman, N. (1995). The end of education: Redefining the value of school. New York: Alfred A Knopf.

Rich, D. (2001). Elearning: A new way to develop employees. Electronic Business, $27(8), 20$. 
Rockwell, K., Scheuer, J., Fritz, S. J., \& Marx, D. B. (1999). Incentives and obstacles influencing higher education faculty and administrators to teach via distance. Online Journal of Distance Learning Administration, 2 (4), Retrieved Agust 17,2007, from http://www.westga.edu/ distance/rockwell2024.html.

Rosenberg, M. (2001) . E-learning: Strategies for delivering knowledge in the digital age. New York: McGraw-Hill.

Rowley, D. J., Lujan, H. D., \& Dolence, M. G. (1998). Strategic choices for the academy: How demand for lifelong learning will re-create higher education.: The Jossey-Bass Higher and Adult Education Series.

Schultz, C. (2001). Surveys of distance learning in the virginia community college system. Inquiry, 6(2), 34 . Segers, G. (2002). Dazed and confused by e-learning. T+D, $56(10), 32$.

Simmons, D. E. (2002). The forum report: E-learning adoption rates and barriers. In The astd e-learning handbook (pp. pp.19-23). New York: McGraw-Hill: In A. Rossett (Ed.).

Smith, D. D., \& Luckasson, R. (1995). Introduction to special education: Teaching in an age of challenge, (pp. 241-295): Needham, MA: Allen \& Bacon. 
Taylor, J. C., \& White, V. J. (1991). Faculty attitudes towards teaching in the distance education mode: An exploratory investigation. Research in Distance Education, $3(3), 7$.

Urdan, T. A., \& Weggen, C. (2000). Corporate e-learning: Exploring a new frontier: W.R. Hambrecht.

Voci, E., \& Young, K. (2001). Blended learning working in a leadership development programme. Industrial \& Commercial Training, 33(5), 157.

Vroom, V. H. (1964). Work and motivation. Oxford, England: Wiley

Wilson, M. S. (2001). Cultural considerations in online instruction and learning. Distance Education, 22(1), $52-64$

Wolters, C. A. (1998). Self-regulated learning and college students' regulation of motivation. Journal of Educational Psychology, $90(2), 224$. 


\section{Appendix A: Survey Form (English Version)}

\section{Dear participant:}

This survey is conducted in partial fulfillment of a doctoral study in the major of curriculum and instruction at West Virginia University. The study seeks to investigate Elearning technologies currently implemented for higher education at King Abdulaziz University (KAU) at Jeddah, Saudi Arabia. Of particular interest are the modes, levels, and influencing factors for the usage among current instructors. This effort is expected to significantly assist KAU in the design of programs targeted at supporting current instructors, encouraging them to use such technologies, as well as facilitating the process of coping with technological advancement.

Please take the time necessary to complete this survey, keeping in mind that your response should be both accurate and representative of your opinion. The survey is composed of three sections: the first section pertains to demographic information; the second section is to determine the scale of general and specific current expertise for Elearning technologies; and the third section is concerned with determining external factors affecting E-learning (e.g. motivational factors, and factors impeding). Mark your response in the first section with a $(\sqrt{ })$. Responses for the second and third sections should be in the form of selecting the appropriate number.

In conclusion, I would like to stress that completing this survey is entirely voluntary, and you have the right to refuse participation in this study. Neither your grades nor your academic status will be jeopardized if you choose not to participate in this study. Additionally, you can omit the response for any question you do not feel comfortable answering. In the event that you choose to complete the survey, your responses will be kept confidential and solely utilized for research purposes. The survey time is estimated at 15 minutes. Please return the completed survey in the attached envelope, and kindly place the envelope in the designated box.

Should you have any questions, please contact me at: $\underline{\text { salbalwi@mix.wvu.edu }}$

Sincerely

Salem A. Albalwi

Ed D candidate

Department of curriculum theory \& practice

College of Human Resources and Education

West Virginia University 
The objective of this survey is to identify factors that influence instructors' use of elearning technologies in their teaching. PLEASE DO NOT IDENTIFY YOURSELF ON THIS SURVEY. ALL INDIVIDUAL RESPONSES WILL REMAIN CONFIDENTIAL. ONLY THE AGGREGATE RESULTS WILL BE REPORTED. Thank you for participating in this survey.

\section{Part I: Demographics}

Please check only one answer for each item, whish applies to you.

Sex: $\quad \square$ Male $\quad \square$ Female

The kind of college in which you teach it:
๑. Scientific college
๑. Humanities college.

How many years of teaching experience in higher education?
$\square 0$ - 5 Years
๑6- 10 Years
$\square 11-15$ Years
$\square$ Over 15 years

\section{Part II: E-learning knowledge:}

Knowledge: You will be asked a variety of questions about e-learning. Before responding think about your own level of expertise related to e-learning. Keep these definitions in mind as you answer the following questions.

Novice: the ability to use only one or two programs if someone else installs them and is available to help (e.g., creating basic student handouts).

Intermediate: able to use at least two selected programs, access email, and use the Internet (e.g., send information by email to the whole class).

Proficient: the ability to use a variety of software, and to accomplish a variety of tasks, such as word processing, spreadsheets, database, presentation software, web authoring software, and Internet applications (e.g., using Front Page to create a web page).

Expert: knowledge of programming, able to install new applications, to troubleshoot software issues, ability to learn from manuals, and to use different platforms (e.g., helping students in solving technical problems).

1 ) Which of the following best describes your level of expertise as an electronic technology user?
1) -Don't use $\square$
2) -Novice
3) -Intermediate
4) - Proficient
5) - Expert $\square$ 
2 ) Which of the following best describes your current expertise with each type of e-learning technologies? (Please check only one response for each item)

\begin{tabular}{|c|c|c|c|c|c|c|}
\hline \multicolumn{7}{|c|}{$\begin{array}{c}\text { Option "0"(D.U.) Don't Use Option "1" (N) Novice Option "2" ( I )Intermediate } \\
\text { Option "3" (P) Proficient } \\
\text { Option "4" (E ) Expert. }\end{array}$} \\
\hline $\mathrm{N}$ & Items & D.U. & $\mathrm{N}$ & I & $\mathrm{P}$ & $\mathrm{E}$ \\
\hline 1 & Use a word processor to create documents. & 0 & 1 & 2 & 3 & 4 \\
\hline 2 & Use a spreadsheet to create charts and graphs. & 0 & 1 & 2 & 3 & 4 \\
\hline 3 & $\begin{array}{l}\text { Use a computer to find resources from the } \\
\text { university library. }\end{array}$ & 0 & 1 & 2 & 3 & 4 \\
\hline 4 & $\begin{array}{l}\text { Searching the web to find information and } \\
\text { resources. }\end{array}$ & 0 & 1 & 2 & 3 & 4 \\
\hline 5 & $\begin{array}{l}\text { Use a database software to set up and access } \\
\text { information. }\end{array}$ & 0 & 1 & 2 & 3 & 4 \\
\hline 6 & Use presentation software (e.g., PowerPoint). & 0 & 1 & 2 & 3 & 4 \\
\hline 7 & $\begin{array}{l}\text { Use graphic software to create illustrations, } \\
\text { slides, or images. }\end{array}$ & 0 & 1 & 2 & 3 & 4 \\
\hline 8 & $\begin{array}{l}\text { Use audio/video clips software to create or } \\
\text { enhance presentations. }\end{array}$ & 0 & 1 & 2 & 3 & 4 \\
\hline 9 & Website design. & 0 & 1 & 2 & 3 & 4 \\
\hline 10 & Use a computer to communicate with others. & 0 & 1 & 2 & 3 & 4 \\
\hline 11 & Use of electronic bulletin board. & 0 & 1 & 2 & 3 & 4 \\
\hline 12 & Use video conferencing & 0 & 1 & 2 & 3 & 4 \\
\hline
\end{tabular}


3 ) Please select the response option $(\mathbf{1}=$ Never, $\mathbf{2}=$ Seldom, $3=$ Occasionally, $4=$ Often, $\mathbf{5}=$ Almost all the time ) that best describes the frequency of your use of each of the following e-learning technologies that you used the past semester.

\begin{tabular}{|c|l|c|c|c|c|c|}
\hline \multicolumn{3}{|l}{$\mathbf{0}=$ Never (0\%) } \\
$\mathbf{3}=$ Often (51-75\%)
\end{tabular}

Part III:Factors that motivate or impede instructors' use e-learning in their teaching. 
1- Please indicate the extent to which the following factors motivate to your use of e-learning techniques in your instruction, according to the following scale:

\begin{tabular}{|c|c|c|c|c|c|c|}
\hline \multirow{2}{*}{\multicolumn{7}{|c|}{ Highly Discouraging (HD) $\quad$ Discouraging (D) $\quad$ Not a Factor (NF) }} \\
\hline $\begin{array}{ll}\text { Encouraging (E) Highly Encouraging (HE) } \\
\end{array}$ & & & & & & \\
\hline $\mathbf{N}$ & Items & HD & $\mathbf{D}$ & NF & $\mathbf{E}$ & HE \\
\hline 1 & Requirement by department or university & 0 & 1 & 2 & 3 & 4 \\
\hline 2 & Administrative encouragement and support & 0 & 1 & 2 & 3 & 4 \\
\hline 3 & Technical support in solving computer problems & 0 & 1 & 2 & 3 & 4 \\
\hline 4 & Support and encouragement from peers & 0 & 1 & 2 & 3 & 4 \\
\hline 5 & Access to software tools for enhancing teaching with technology & 0 & 1 & 2 & 3 & 4 \\
\hline 6 & Credit toward promotion and tenure & 0 & 1 & 2 & 3 & 4 \\
\hline 7 & Professional prestige and status & 0 & 1 & 2 & 3 & 4 \\
\hline 8 & Training programs and support & 0 & 1 & 2 & 3 & 4 \\
\hline 9 & Reduced teaching load. & 0 & 1 & 2 & 3 & 4 \\
\hline 10 & Opportunity to improve teaching & 0 & 1 & 2 & 3 & 4 \\
\hline 11 & Rewards/recognition for innovation in teaching & 0 & 1 & 2 & 3 & 4 \\
\hline 12 & $\begin{array}{l}\text { Time available to learn/pursue the integration of e-learning } \\
\text { technologies }\end{array}$ & 0 & 1 & 2 & 3 & 4 \\
\hline 13 & Increase in salary. & 0 & 1 & 2 & 3 & 4 \\
\hline 14 & $\begin{array}{l}\text { Opportunity to reach new audience that can not attend classes on } \\
\text { campus. }\end{array}$ & 0 & 1 & 2 & 3 & 4 \\
\hline 15 & Opportunity for scholarly pursuit & 0 & 1 & 2 & 3 & 4 \\
\hline 16 & Funding for materials/expenses & 0 & 1 & 2 & 3 & 4 \\
\hline 17 & $\begin{array}{l}\text { Classroom technology infrastructure (e.g., wiring, computers, or } \\
\text { projectors) }\end{array}$ & 0 & 1 & 2 & 3 & 4 \\
\hline 18 & Resources about how to apply technology in teaching. & 0 & 1 & 2 & 3 & 4 \\
\hline 19 & Student' access to resources & 0 & 1 & 2 & 3 & 4 \\
\hline 20 & Student' computer skills & 0 & 1 & 2 & 3 & 4 \\
\hline 21 & My computer skills & 0 & 1 & 2 & 3 & 4 \\
\hline 22 & My colleagues' computer skills & 0 & 1 & 2 & 3 & 4 \\
\hline 23 & Opportunity to enhance communication with others. & 0 & 1 & 2 & 3 & 4 \\
\hline
\end{tabular}




\section{2- Please indicate the extent to which the following factors impede to your use} of e-learning techniques in your instruction, according to the following scale:

\begin{tabular}{|c|c|c|c|c|c|c|}
\hline & $\begin{array}{l}\text { B) No barriers (0\%) } \\
\text { barriers (26-50\%) } \\
\text { any barrier (76-100\%) }\end{array}$ & $\begin{array}{l}s(1 \\
5 \%)\end{array}$ & & & & \\
\hline $\mathbf{N}$ & Items & & & & & \\
\hline 1 & Lack of interest. & 0 & 1 & 2 & 3 & 4 \\
\hline 2 & Lack of time to learn new technology & 0 & 1 & 2 & 3 & 4 \\
\hline 3 & $\begin{array}{l}\text { Negative comments made by colleagues about } \\
\text { e-learning technologies. }\end{array}$ & 0 & 1 & 2 & 3 & 4 \\
\hline 4 & $\begin{array}{l}\text { Lack of support and encouragement from } \\
\text { administrative. }\end{array}$ & 0 & 1 & 2 & 3 & 4 \\
\hline 5 & Lack of support and encouragement from peers. & 0 & 1 & 2 & 3 & 4 \\
\hline 6 & Lack of instructors' technological knowledge. & 0 & 1 & 2 & 3 & 4 \\
\hline 7 & Lack of students' technological knowledge. & 0 & 1 & 2 & 3 & 4 \\
\hline 8 & Lack of training programs. & 0 & 1 & 2 & 3 & 4 \\
\hline 9 & $\begin{array}{l}\text { Lack of face-to-face interaction in e-learning } \\
\text { courses. }\end{array}$ & 0 & 1 & 2 & 3 & 4 \\
\hline 10 & Lack of credit toward promotion and tenure. & 0 & 1 & 2 & 3 & 4 \\
\hline 11 & Lack of funding for materials/expenses. & 0 & 1 & 2 & 3 & 4 \\
\hline 12 & $\begin{array}{l}\text { Lack of rewards/recognition for innovation in } \\
\text { teaching }\end{array}$ & 0 & 1 & 2 & 3 & 4 \\
\hline 13 & Concern about course quality. & 0 & 1 & 2 & 3 & 4 \\
\hline 14 & $\begin{array}{l}\text { Lack of technical support in solving computer } \\
\text { problems. }\end{array}$ & 0 & 1 & 2 & 3 & 4 \\
\hline 15 & Lack of technological infrastructure. & 0 & 1 & 2 & 3 & 4 \\
\hline 16 & Lack of Student' access to resources. & 0 & 1 & 2 & 3 & 4 \\
\hline 17 & $\begin{array}{l}\text { Lack of resources about how to apply technology } \\
\text { in teaching. }\end{array}$ & 0 & 1 & 2 & 3 & 4 \\
\hline 18 & Security concerns. & 0 & 1 & 2 & 3 & 4 \\
\hline
\end{tabular}

Thank you for your time 


\section{Appendix B: Survey Form (Arabic Version) \\ بسم الله الرحمن الرحيم}

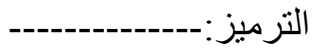

العو امل الااخلية والخارجية الموثرة في استخدام اعضاء هيئة التدريس للتطليم الإكتروني

عزيزي المشارك بالاستبانة،

السلام عليكم ورحمة الله وبركاته،،،

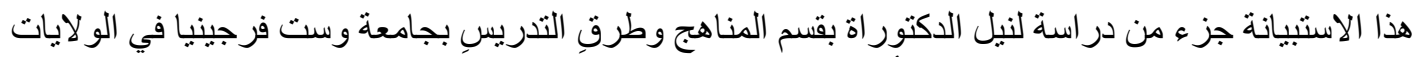

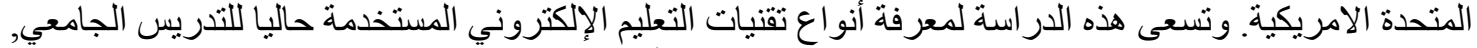

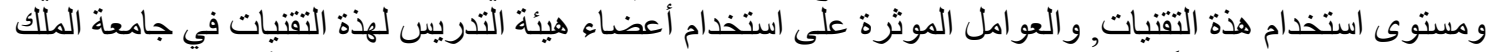

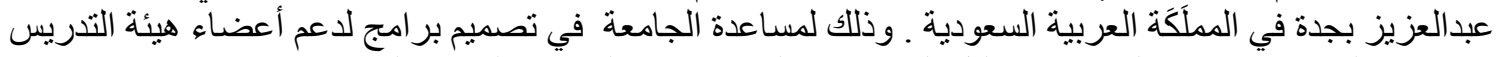

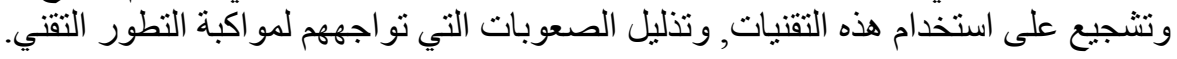

أمل التكرم بتعبئة هذا الاستبانة حيث تكون إجابتلك دقيقة ومعبرة عن ر أيك ـ ان هذه الاستبانة مكونة من ثناث

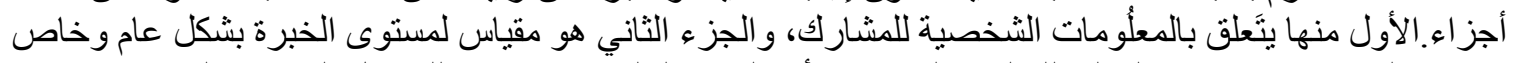

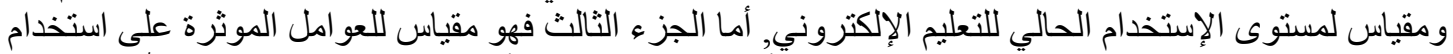

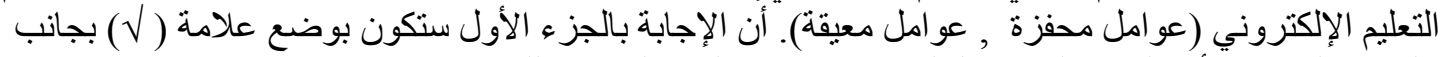

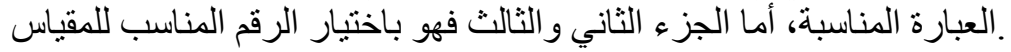

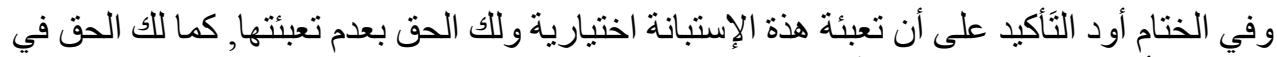

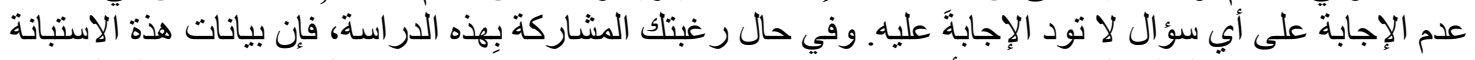

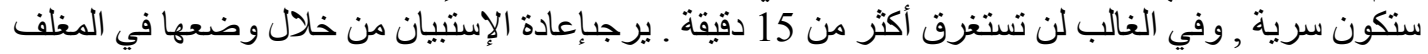
المرفق ثم وضعها في الصندوق المغلق في قسمك.

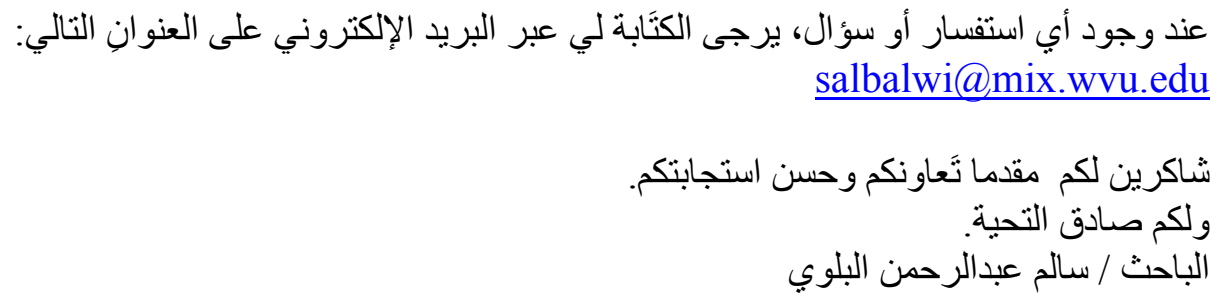


الجزء الأول : المطلومات الشخصيه:-

فضلا ضع اشارة ( ل ) أمام العبارة المناسبة : :

أنثى

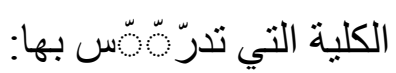

口لية علمية

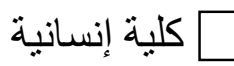

عدد سنوات الخبرة التي أمضيتها في التدريس الجامعي:
سنوات
$\square$ سنوات 10,6
$\square 15,11 \quad$ سنة
سنة 15 أكثر من

الجزء الثاني: معارف التعليم الإكتروني (مستوى الخبرة العامة , مستوى الخبرة الخاصة, مستوى الاستخدام الحالي).

في ما يلي بعض التعريفات التي ستساعدك على تحليد مستوى خبرتك العامة في التعليم الإكتروني :

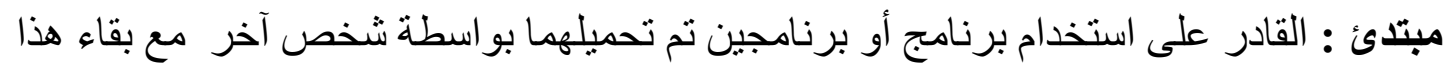

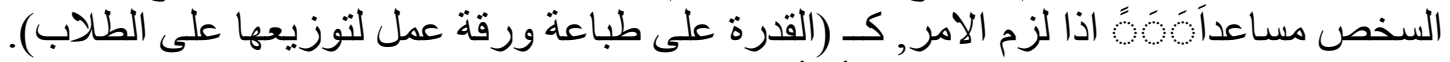
متوسط: القادر على استخدام برنامجين أو أكثر كاستخدام الإنترنت و البردئ البريد الإلكتروني,كـ (ارسال معلومات للطلاب عن طريق البريد الإلكتروني).

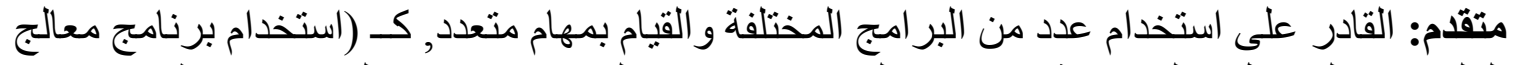

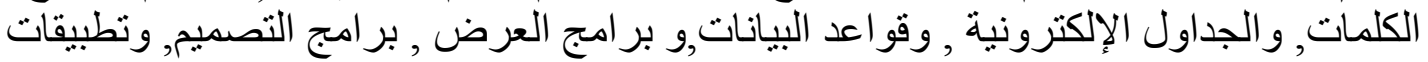

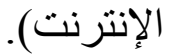

خبير: القادر على ادخال البر امج و التطبيقات المختلفة بالحاسوب و وتحميلها, و الإلمام بمهار ات البرمجة ومساعدة الطلاب على حل المشكلات التقنية. أ- حدد مستوى خبرتك العامة في استخدام الحاسوب:

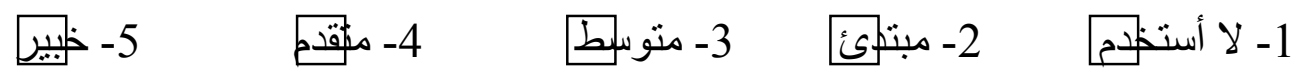


ب ـ ماهو مستوى خبرتك الحالية في استخام كلا من البرامج و التطبيقات التالية:

\begin{tabular}{|c|c|c|c|c|c|c|}
\hline خبير & 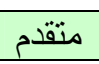 & متوسط & مبتدىء & لا أستخدم & 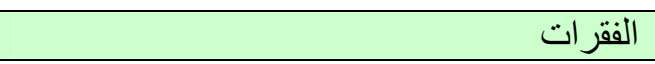 & 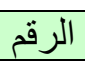 \\
\hline 4 & 3 & 2 & 1 & 0 & أور اقتخدام معل الطلاب النصوص كـــ (الوورد) لتصميم & 1 \\
\hline 4 & 3 & 2 & 1 & 0 & 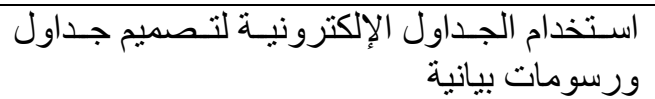 & 2 \\
\hline 4 & 3 & 2 & 1 & 0 & أو مر اجع منتو شبكة الإنتر نت للحصول على معلومات & 3 \\
\hline 4 & 3 & 2 & 1 & 0 & استخدام قو اعد البيانات للحصول على المعلومات & 4 \\
\hline 4 & 3 & 2 & 1 & 0 & 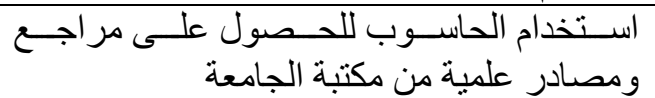 & 5 \\
\hline 4 & 3 & 2 & 1 & 0 & استخدام بر امج العرض ك(بوربوينت) & 6 \\
\hline 4 & 3 & 2 & 1 & 0 & إيضـاحية إلخدامـوب لتـصميم صـور ورسـومات & 7 \\
\hline 4 & 3 & 2 & 1 & 0 & لزيادة فعالية العملية التعليمية المسمو عة أو المرئيـة & 8 \\
\hline 4 & 3 & 2 & 1 & 0 & تصميم موقع إلكتروني & 9 \\
\hline 4 & 3 & 2 & 1 & 0 & استخدام الحاسوب للاتتصال بـالآخرين و التفاعل & 10 \\
\hline 4 & 3 & 2 & 1 & 0 & استخدام لوحة الإعلانات الإلكترونية & 11 \\
\hline 4 & 3 & 2 & 1 & 0 & استخدام المؤتمرات المرئية & 12 \\
\hline
\end{tabular}


ج - حدد مستوى استخدامك لتقنيات التعليم الالكتروني خلال الفصل الدر اسي حسب المقياس المحدد

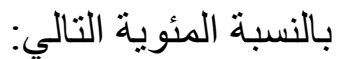

\begin{tabular}{|c|c|c|c|c|c|c|}
\hline \multicolumn{7}{|c|}{ 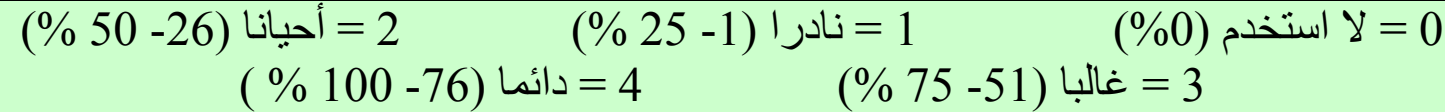 } \\
\hline دائما & غالبا & |أحيانا & نادرا & لا استخدم & الفقر ات & الرقم \\
\hline 4 & 3 & 2 & 1 & 0 & 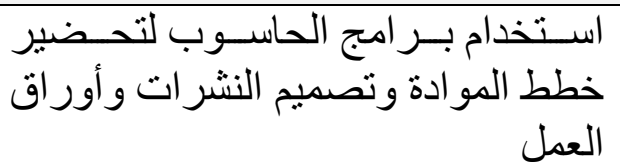 & 1 \\
\hline 4 & 3 & 2 & 1 & 0 & 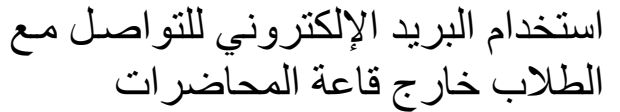 & 2 \\
\hline 4 & 3 & 2 & 1 & 0 & عقد ساعات مكتبية افتر اضبية & 3 \\
\hline 4 & 3 & 2 & 1 & 0 & 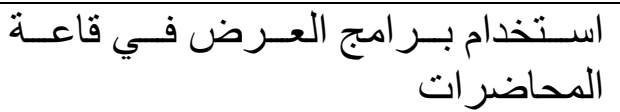 & 4 \\
\hline 4 & 3 & 2 & 1 & 0 & استخدام لوحة الإعلانات الإلكترونية & 5 \\
\hline 4 & 3 & 2 & 1 & 0 & عقدمحاضر ات بواسطة الإنتر نت & 6 \\
\hline 4 & 3 & 2 & 1 & 0 & عقد اختبار ات بو اسطة الإنتر نت & 7 \\
\hline 4 & 3 & 2 & 1 & 0 & 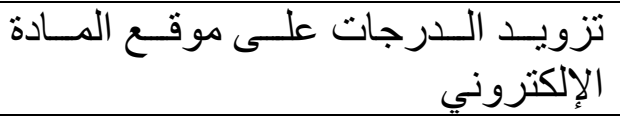 & 8 \\
\hline 4 & 3 & 2 & 1 & 0 & استخدام الإنتر نت في عمليات البحث & 9 \\
\hline 4 & 3 & 2 & 1 & 0 & المادة الإلكترونـي القراء المطلوبـة على موقـع & 10 \\
\hline 4 & 3 & 2 & 1 & 0 & استخدام غرف الحوار على الشبكه & 11 \\
\hline 4 & 3 & 2 & 1 & 0 & إلكترونيا علتى الو اجبـات و أوراق العمـل & 12 \\
\hline 4 & 3 & 2 & 1 & 0 & المؤتمر ات الإلكترونية & 13 \\
\hline 4 & 3 & 2 & 1 & 0 & استخدام الأشرطة المرئية بالتدريس & 14 \\
\hline 4 & 3 & 2 & 1 & 0 & استخدام الأشرطة المسموعة بالتدريس & 15 \\
\hline
\end{tabular}


الجزء الثالث: العو امل المؤثرة في استخدام تقنيات التعليم الإلكتروني ( عوامل محفزة , عوامل معيقة):

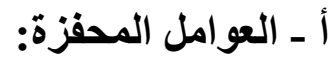
إلى أي مدى تشجعك كل من العوامل التالية على استخدام تقنيات التعلم الإلكتروني في العملية التعليمية:

\begin{tabular}{|c|c|c|c|c|c|c|}
\hline 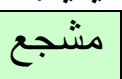 & مشجع & محايد & غير & غير مشجع & الفقرات & 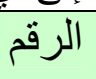 \\
\hline 4 & 3 & 2 & 1 & 0 & 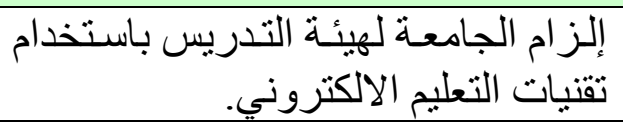 & 1 \\
\hline 4 & 3 & 2 & 1 & 0 & إدارة الجمامعة والتشجيع مـن عهــادة الكليــة أو & 2 \\
\hline 4 & 3 & 2 & 1 & 0 & 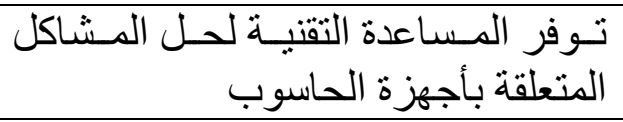 & 3 \\
\hline 4 & 3 & 2 & 1 & 0 & دعم الزملاء وتشجيعهم & 4 \\
\hline 4 & 3 & 2 & 1 & 0 & 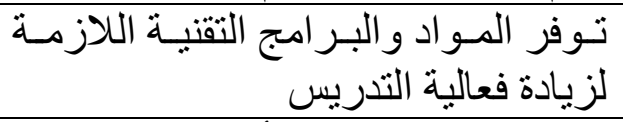 & 5 \\
\hline 4 & 3 & 2 & 1 & 0 & الحصول على ترقية أو منصب & 6 \\
\hline 4 & 3 & 2 & 1 & 0 & كسب سمعة وظيفية منميزة & 7 \\
\hline 4 & 3 & 2 & 1 & 0 & توفر بر امج التدريب & 8 \\
\hline 4 & 3 & 2 & 1 & 0 & تخفيف العبء الدر اسي & 9 \\
\hline 4 & 3 & 2 & 1 & 0 & زيادة فعالية العملية التعليمية & 10 \\
\hline 4 & 3 & 2 & 1 & 0 & 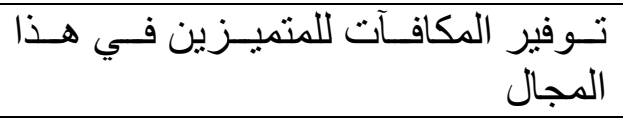 & 11 \\
\hline 4 & 3 & 2 & 1 & 0 & تقتنيات التعليم الإلكتروني لتعلم كيفية استخدام & 12 \\
\hline 4 & 3 & 2 & 1 & 0 & زيادة الر اتب & 13 \\
\hline 4 & 3 & 2 & 1 & 0 & إتاحة الفرصة للتدريس عن بعد & 14 \\
\hline 4 & 3 & 2 & 1 & 0 & اتاحة الفرصة لمتابعة البحث العلمي & 15 \\
\hline 4 & 3 & 2 & 1 & 0 & توفر الدعم المالي لشر اء المو اد اللازمة & 16 \\
\hline 4 & 3 & 2 & 1 & 0 & 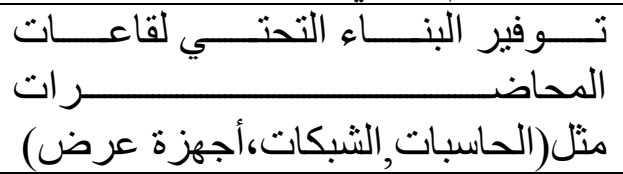 & 17 \\
\hline 4 & 3 & 2 & 1 & 0 & 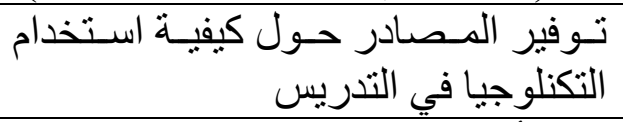 & 18 \\
\hline 4 & 3 & 2 & 1 & 0 & توفر أجهزة الحاسوب و البر امج للطلاب & 19 \\
\hline 4 & 3 & 2 & 1 & 0 & امتلاك الطلبه للمهار ات اللازمة & 20 \\
\hline 4 & 3 & 2 & 1 & 0 & الحتلاسك لك للمهـار ات اللازمـة لإسـتخذام & 21 \\
\hline 4 & 3 & 2 & 1 & 0 & امتلاك زملائك للمهار ات اللازمة & 22 \\
\hline 4 & 3 & 2 & 1 & 0 & و التفاعل معرح أكثر للتو اصل مـع الآخرين & 23 \\
\hline
\end{tabular}


ب - العوامل المعيقة: الى اي مدى تسهم كل من العو امل التالية في إعاقة استخدام تقنيات التعليم الالكتروني في تدريسك:

\begin{tabular}{|c|c|c|c|c|c|c|}
\hline \multicolumn{7}{|c|}{ 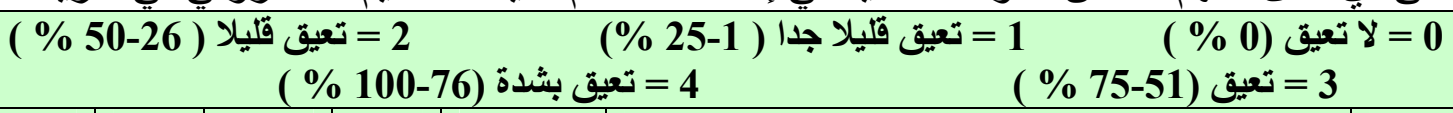 } \\
\hline تعيق & تعيق & تعليلا & تقليلا & 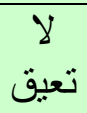 & الفقرات & 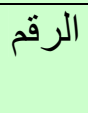 \\
\hline 4 & 3 & 2 & 1 & 0 & عدم الاهتمام و الر غبة بهذا المجال & 1 \\
\hline 4 & 3 & 2 & 1 & 0 & 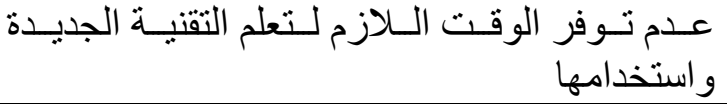 & 2 \\
\hline 4 & 3 & 2 & 1 & 0 & تعليقات الزملاء السلبية حول التعليم الإلكتروني & 3 \\
\hline 4 & 3 & 2 & 1 & 0 & عدم توفر دعم إدارة الجامعة وتتجيعها & 4 \\
\hline 4 & 3 & 2 & 1 & 0 & عدم توفر الدعم والتتجيع من الزملاء & 5 \\
\hline 4 & 3 & 2 & 1 & 0 & عدم امتلاكك المعرفة اللازمة لاستخدام التقنية & 6 \\
\hline 4 & 3 & 2 & 1 & 0 & التقنـات امتلاك الطـلاب المعرفـة اللازمــة لإسـتخدام & 7 \\
\hline 4 & 3 & 2 & 1 & 0 & النقص في بر امج التدريب & 8 \\
\hline 4 & 3 & 2 & 1 & 0 & بعدم توفر التفاعل المباثـر في برامج التعليم عن & 9 \\
\hline 4 & 3 & 2 & 1 & 0 & ترقية أو منصدام التكنلوجيـا لا يـساهم في الحـصول على & 10 \\
\hline 4 & 3 & 2 & 1 & 0 & عدم توفر الدعم المالي لثر اء المواد اللازمة & 11 \\
\hline 4 & 3 & 2 & 1 & 0 & عدم توفر المكافآت للمتميزين في هذا المجال & 12 \\
\hline 4 & 3 & 2 & 1 & 0 & التدريس بادك أنتخدام التكنلوجيـا لا يزيد من فعالية & 13 \\
\hline 4 & 3 & 2 & 1 & 0 & بالحساسوبو توفر المساعدة التقنية لحل المشاكل المتعلقة & 14 \\
\hline 4 & 3 & 2 & 1 & 0 & قاعدات المحراضر البنــة التحتيـة لاستخدام التكنلوجيـا في & 15 \\
\hline 4 & 3 & 2 & 1 & 0 & للطلبة تـوفر أجهـزة الحاسـوب و البـر امج المختلفـة & 16 \\
\hline 4 & 3 & 2 & 1 & 0 & نقص المصادر حول كيفية استخدام التكنلوجيا في & 17 \\
\hline 4 & 3 & 2 & 1 & 0 & المخاوف الأمنية على سرية المعلومات & 18 \\
\hline
\end{tabular}




\section{Appendix C: English Form of the Survey Evaluation}

Dear Participant,

The objective of this survey is to identify factors that influence instructors' use of e-learning technologies in the delivery of instruction. Please fill out the attached survey first and then complete the evaluation form by checking the most correct response for each item. Your responses will help improve the quality of the survey and put it in its final form to reflect the goal that it was designed to accomplish.

1. Time required completing the survey:

$\square$-Less than 10 minutes.

$\square$-From 10 to 15 minutes.

$\square$-From 15 to 20 minutes.

$\square$-More than 20 minutes

2. The survey's items were:

$\square$ - clear and easy to understand.

$\square$-Diffuse, but I could complete the survey.

$\square$-Not clear and hard to understand.

3. When I read the survey, I found that:

$\square$-All the words were clear and understandable.

$\square$-Some words were not clear, but they did not influence my answers.

$\square$-Some words were completely unclear and influenced my answers.

4. Please circle the number of items that you found it difficult to understand and provide your suggestion or comments to help making it more clear and understandable.

Part I : Demographic Items:

Item $\mathrm{N}: 1,2,3$.

Suggestions or Comments: 


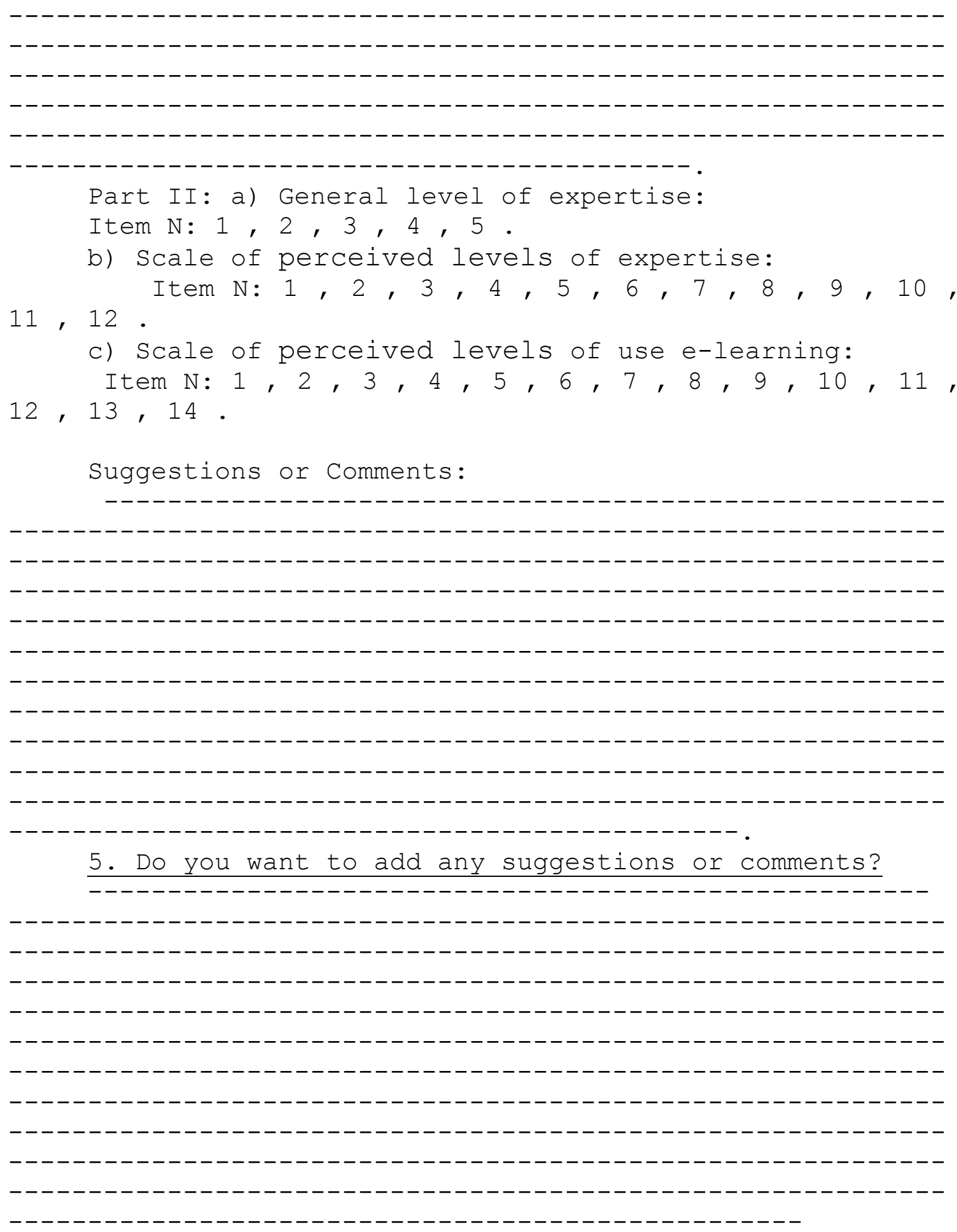

Thank you for your time. 


\section{Appendix D:Arabic Form of the Survey Evaluation}

بسم, الله الر بمن المر بيه

\section{نموذج تقييم الاستبانة}

\section{عزيزي المشارئ بالاستبانة: السلام عليكم ورحمة الله وبركاته، ، الاسيلهة}

هدفُ هذه الاسنبانة هو جمعُ بياناتٍ عن العوامل المؤثرة على استخدام أعضاء هيئة التدريس

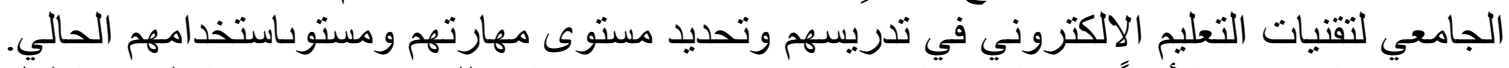

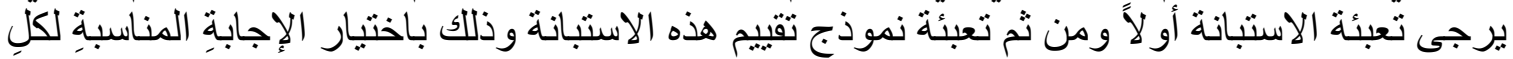

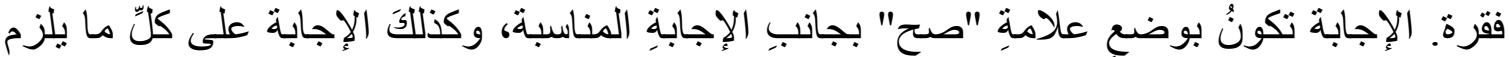

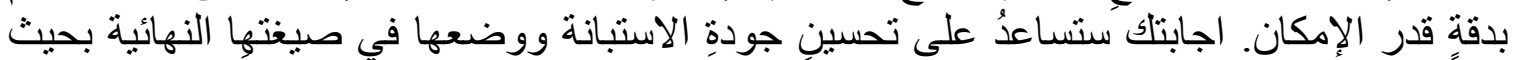
تعكس الهدف المرجوّ منها. شاكرين لكم تعاو نكم ومساعدنكم.

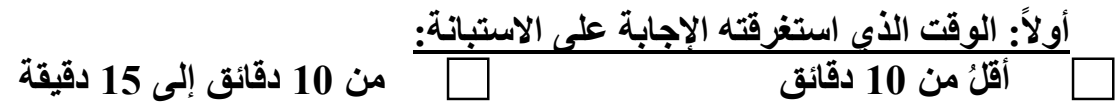

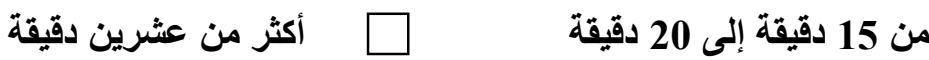

$$
\begin{aligned}
& \text { بانياً: فقراتُ الاستبانة كاتت: } \\
& \text { كثيرة، ولكن أمكنتي الفهم ومواصلة الإجابة على الاستبانة } \\
& \text { غير مفهومة وغير واضحة ومن الصعب استيعابها والإجابة عليها }
\end{aligned}
$$

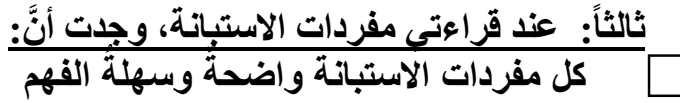

$$
\begin{aligned}
& \text { بعض مفرداته غير مفهومة، ولكنها ماكاتت لتأثرَّ على قدرتي على الإجابة } \\
& \text { بعض المفردات لم تكن واضحة بحيثُ أثرت على قرتي على الإجابة }
\end{aligned}
$$


رابعاً: برجيى وضع دائرة حول رقم الفقرة أو أرقام الفقرات التى وجدت صعوبةًة في فهمها، وكتابة تعليق أو اقتراح

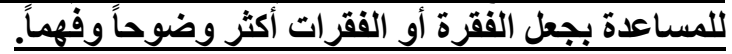

الجزء الأول: المعلومات الثخصية:

رقم الفقرة: 12

التعليق أو المقترح:

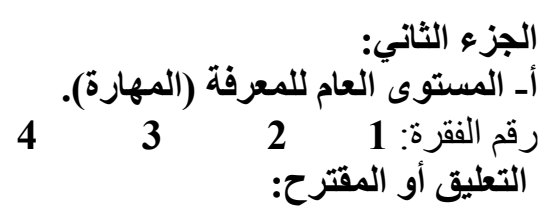

رقم الفقرة: 11 رقياس المستوى الخاص للمعرفة (المهارة). .12

التعليق أو المقترح:

ج- مقياس مستونالاستخدام الحالي لتقتيات التعليم الاكتروني

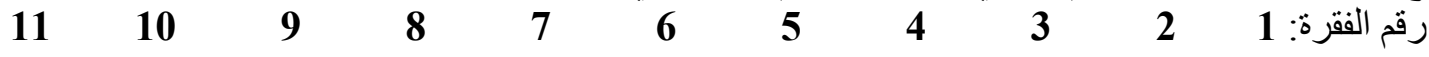
$\begin{array}{lllllllllll}22 & 21 & 20 & 19 & 18 & 17 & 16 & 15 & 14 & 13 & 12\end{array}$

.23

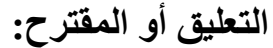




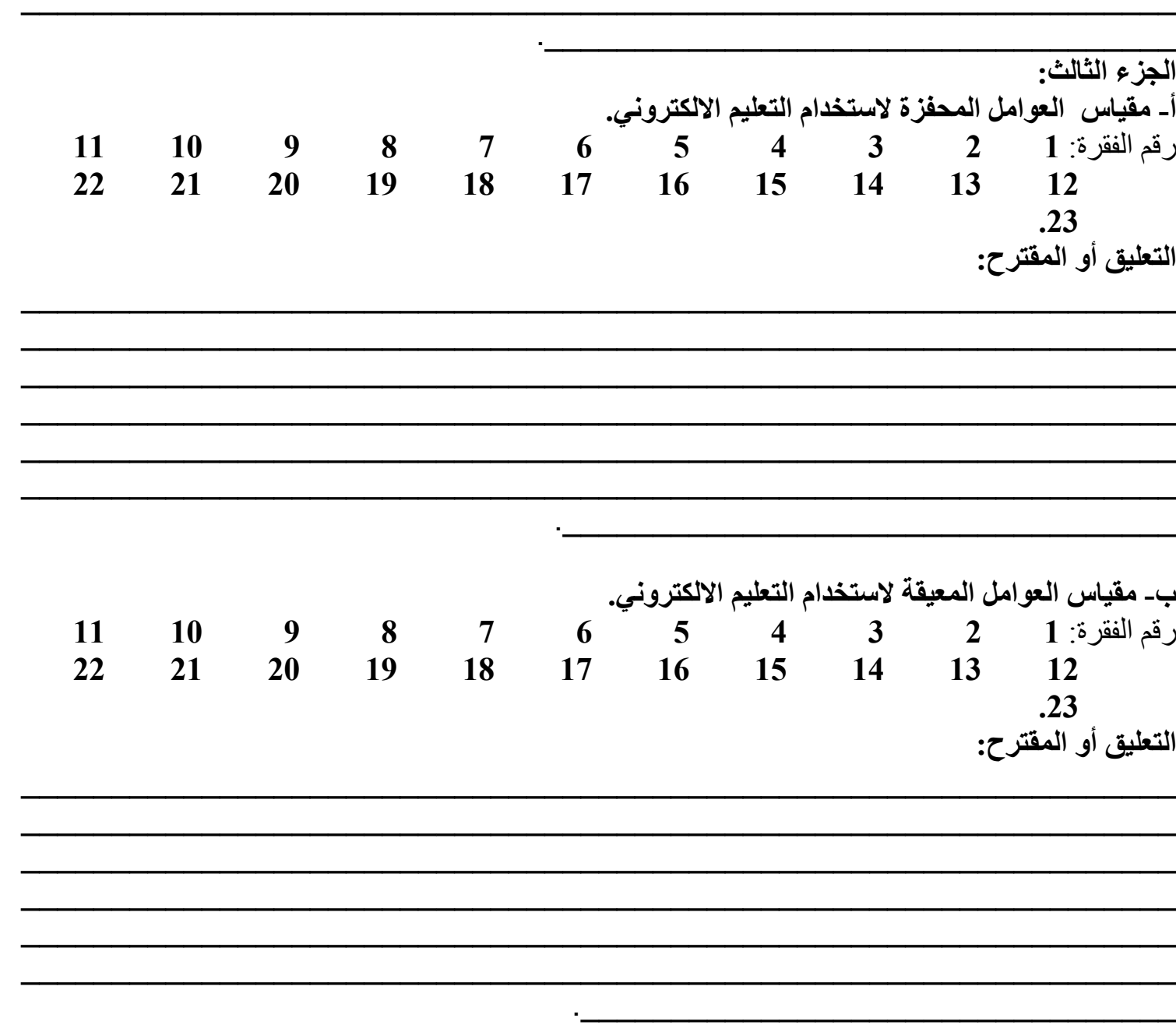

خامساً: هل تود التعليق أو الاقتراح على الاستبانة بثكل عام أو إضافة شىء؟

انتهى نموذج تقييم الاستبانة، وشكراً جزيلاً على مساهتك القيمة. 


\section{Appendix E: percentage of General Expertise by Academic field}

\begin{tabular}{|c|c|c|c|c|c|}
\hline & & & \multicolumn{2}{|c|}{ Academic field } & \multirow[b]{2}{*}{ Total } \\
\hline & & & scientific & Humanities & \\
\hline \multirow{20}{*}{$\begin{array}{l}\text { Genral } \\
\text { Expertise }\end{array}$} & \multirow{4}{*}{ Don't use } & Count & 0 & 4 & 4 \\
\hline & & $\%$ within Genral Expertise & $.0 \%$ & $100.0 \%$ & $100.0 \%$ \\
\hline & & $\%$ within Academic field & $.0 \%$ & $4.3 \%$ & $1.8 \%$ \\
\hline & & $\%$ of Total & $.0 \%$ & $1.8 \%$ & $1.8 \%$ \\
\hline & \multirow[t]{4}{*}{ Novice } & Count & 2 & 14 & 16 \\
\hline & & $\%$ within Genral Expertis & $12.5 \%$ & $87.5 \%$ & $100.0 \%$ \\
\hline & & $\%$ within Academic field & $1.5 \%$ & $15.2 \%$ & $7.0 \%$ \\
\hline & & $\%$ of Total & $.9 \%$ & $6.2 \%$ & $7.0 \%$ \\
\hline & \multirow[t]{4}{*}{ Intermediate } & Count & 42 & 23 & 65 \\
\hline & & $\%$ within Genral Expertis & $64.6 \%$ & $35.4 \%$ & $100.0 \%$ \\
\hline & & $\%$ within Academic field & $31.1 \%$ & $25.0 \%$ & $28.6 \%$ \\
\hline & & $\%$ of Total & $18.5 \%$ & $10.1 \%$ & $28.6 \%$ \\
\hline & \multirow[t]{4}{*}{ Proficient } & Count & 78 & 38 & 116 \\
\hline & & $\%$ within Genral Expertis & $67.2 \%$ & $32.8 \%$ & $100.0 \%$ \\
\hline & & $\%$ within Academic field & $57.8 \%$ & $41.3 \%$ & $51.1 \%$ \\
\hline & & $\%$ of Total & $34.4 \%$ & $16.7 \%$ & $51.1 \%$ \\
\hline & \multirow[t]{4}{*}{ Expert } & Count & 13 & 13 & 26 \\
\hline & & $\%$ within Genral Expertis & $50.0 \%$ & $50.0 \%$ & $100.0 \%$ \\
\hline & & $\%$ within Academic field & $9.6 \%$ & $14.1 \%$ & $11.5 \%$ \\
\hline & & $\%$ of Total & $5.7 \%$ & $5.7 \%$ & $11.5 \%$ \\
\hline \multirow{4}{*}{\multicolumn{2}{|c|}{ Total }} & Count & 135 & 92 & 227 \\
\hline & & $\%$ within Genral Expertis & $59.5 \%$ & $40.5 \%$ & $100.0 \%$ \\
\hline & & $\%$ within Academic field & $100.0 \%$ & $100.0 \%$ & $100.0 \%$ \\
\hline & & $\%$ of Total & $59.5 \%$ & $40.5 \%$ & $100.0 \%$ \\
\hline
\end{tabular}




\section{Appendix F: percentage of General Expertise by Sex}

\begin{tabular}{|c|c|c|c|c|c|}
\hline \multicolumn{6}{|c|}{ Genral Expertise * Sex Crosstabulation } \\
\hline & & & \multicolumn{2}{|c|}{ Sex } & \multirow[b]{2}{*}{ Total } \\
\hline & & & male & female & \\
\hline \multirow{20}{*}{$\begin{array}{l}\text { Genral } \\
\text { Expertise }\end{array}$} & \multirow[t]{4}{*}{ Don't use } & Count & 0 & 4 & 4 \\
\hline & & $\%$ within Genral Expertis & $.0 \%$ & $100.0 \%$ & $100.0 \%$ \\
\hline & & $\%$ within Sex & $.0 \%$ & $3.1 \%$ & $1.8 \%$ \\
\hline & & $\%$ of Total & $.0 \%$ & $1.8 \%$ & $1.8 \%$ \\
\hline & \multirow[t]{4}{*}{ Novice } & Count & 8 & 8 & 16 \\
\hline & & $\%$ within Genral Expertis & $50.0 \%$ & $50.0 \%$ & $100.0 \%$ \\
\hline & & $\%$ within Sex & $8.0 \%$ & $6.3 \%$ & $7.0 \%$ \\
\hline & & $\%$ of Total & $3.5 \%$ & $3.5 \%$ & $7.0 \%$ \\
\hline & \multirow[t]{4}{*}{ Intermediate } & Count & 22 & 43 & 65 \\
\hline & & $\%$ within Genral Expertis & $33.8 \%$ & $66.2 \%$ & $100.0 \%$ \\
\hline & & $\%$ within Sex & $22.0 \%$ & $33.9 \%$ & $28.6 \%$ \\
\hline & & $\%$ of Total & $9.7 \%$ & $18.9 \%$ & $28.6 \%$ \\
\hline & \multirow[t]{4}{*}{ Proficient } & Count & 47 & 69 & 116 \\
\hline & & $\%$ within Genral Expertis & $40.5 \%$ & $59.5 \%$ & $100.0 \%$ \\
\hline & & $\%$ within Sex & $47.0 \%$ & $54.3 \%$ & $51.1 \%$ \\
\hline & & $\%$ of Total & $20.7 \%$ & $30.4 \%$ & $51.1 \%$ \\
\hline & \multirow[t]{4}{*}{ Expert } & Count & 23 & 3 & 26 \\
\hline & & $\%$ within Genral Expertis & $88.5 \%$ & $11.5 \%$ & $100.0 \%$ \\
\hline & & $\%$ within Sex & $23.0 \%$ & $2.4 \%$ & $11.5 \%$ \\
\hline & & $\%$ of Total & $10.1 \%$ & $1.3 \%$ & $11.5 \%$ \\
\hline \multirow{4}{*}{\multicolumn{2}{|c|}{ Total }} & Count & 100 & 127 & 227 \\
\hline & & $\%$ within Genral Expertis & $44.1 \%$ & $55.9 \%$ & $100.0 \%$ \\
\hline & & $\%$ within Sex & $100.0 \%$ & $100.0 \%$ & $100.0 \%$ \\
\hline & & $\%$ of Total & $44.1 \%$ & $55.9 \%$ & $100.0 \%$ \\
\hline
\end{tabular}




\section{Appendix G: 3-way Factorial ANVA for General Expertise}

\section{Univariate Analysis of Variance}

Between-Subjects Factors
\begin{tabular}{|ll|l|r|}
\hline & & Value Label & \multicolumn{1}{|c|}{$\mathrm{N}$} \\
\hline Sex & 1 & male & 100 \\
& 2 & female & 127 \\
Academic & 1 & scientific & 135 \\
field & 2 & Humanities & 92 \\
Experience & 0 & $0-5$ & 50 \\
& 1 & $6-10$ & 42 \\
& 2 & $11-15$ & 43 \\
& 3 & $15+$ & 92 \\
\hline
\end{tabular}


Descriptive Statistics

Dependent Variable: General Expertise

\begin{tabular}{|c|c|c|c|c|c|}
\hline Sex & Academic field & Experience & Mean & Std. Deviation & $\mathrm{N}$ \\
\hline \multirow[t]{15}{*}{ male } & \multirow[t]{5}{*}{ scientific } & $0-5$ & 2.88 & .857 & 17 \\
\hline & & $6-10$ & 2.40 & .548 & 5 \\
\hline & & $11-15$ & 2.90 & .738 & 10 \\
\hline & & $15+$ & 2.86 & .705 & 28 \\
\hline & & Total & 2.83 & .740 & 60 \\
\hline & \multirow[t]{5}{*}{ Humanities } & $0-5$ & 2.14 & 1.464 & 7 \\
\hline & & $6-10$ & 3.15 & .987 & 13 \\
\hline & & $11-15$ & 3.00 & .000 & 5 \\
\hline & & $15+$ & 2.93 & .961 & 15 \\
\hline & & Total & 2.88 & 1.042 & 40 \\
\hline & \multirow[t]{5}{*}{ Total } & $0-5$ & 2.67 & 1.090 & 24 \\
\hline & & $6-10$ & 2.94 & .938 & 18 \\
\hline & & $11-15$ & 2.93 & .594 & 15 \\
\hline & & $15+$ & 2.88 & .793 & 43 \\
\hline & & Total & 2.85 & .869 & 100 \\
\hline \multirow[t]{15}{*}{ female } & \multirow[t]{5}{*}{ scientific } & $0-5$ & 2.61 & .502 & 18 \\
\hline & & $6-10$ & 2.73 & .647 & 11 \\
\hline & & $11-15$ & 3.00 & .408 & 13 \\
\hline & & $15+$ & 2.61 & .556 & 33 \\
\hline & & Total & 2.69 & .545 & 75 \\
\hline & \multirow[t]{5}{*}{ Humanities } & $0-5$ & 1.50 & .926 & 8 \\
\hline & & $6-10$ & 2.38 & .650 & 13 \\
\hline & & $11-15$ & 2.27 & .961 & 15 \\
\hline & & $15+$ & 2.13 & 1.088 & 16 \\
\hline & & Total & 2.13 & .950 & 52 \\
\hline & \multirow[t]{5}{*}{ Total } & $0-5$ & 2.27 & .827 & 26 \\
\hline & & $6-10$ & 2.54 & .658 & 24 \\
\hline & & $11-15$ & 2.61 & .832 & 28 \\
\hline & & $15+$ & 2.45 & .792 & 49 \\
\hline & & Total & 2.46 & .785 & 127 \\
\hline \multirow[t]{15}{*}{ Total } & \multirow[t]{5}{*}{ scientific } & $0-5$ & 2.74 & .701 & 35 \\
\hline & & $6-10$ & 2.63 & .619 & 16 \\
\hline & & $11-15$ & 2.96 & .562 & 23 \\
\hline & & $15+$ & 2.72 & .636 & 61 \\
\hline & & Total & 2.76 & .640 & 135 \\
\hline & \multirow[t]{5}{*}{ Humanities } & $0-5$ & 1.80 & 1.207 & 15 \\
\hline & & $6-10$ & 2.77 & .908 & 26 \\
\hline & & $11-15$ & 2.45 & .887 & 20 \\
\hline & & $15+$ & 2.52 & 1.092 & 31 \\
\hline & & Total & 2.46 & 1.053 & 92 \\
\hline & \multirow[t]{5}{*}{ Total } & $0-5$ & 2.46 & .973 & 50 \\
\hline & & $6-10$ & 2.71 & .805 & 42 \\
\hline & & $11-15$ & 2.72 & .766 & 43 \\
\hline & & $15+$ & 2.65 & .818 & 92 \\
\hline & & Total & 2.63 & .843 & 227 \\
\hline
\end{tabular}




\section{Levene's Test of Equality of Error Variancess}

Dependent Variable: General Expertise

\begin{tabular}{|l|l|l|l|}
\hline $\mathrm{F}$ & $\mathrm{df} 1$ & $\mathrm{df} 2$ & Sig. \\
\hline 3.471 & 15 & 211 & .000 \\
\hline
\end{tabular}

Tests the null hypothesis that the error variance of the dependt variable is equal across groups.

a. Design: Intercept+Sex+Afield+Experien+Sex *Afield+Se:

${ }^{*}$ Experien+Afield * Experien+Sex * Afield * Experien

Tests of Between-Subjects Effects

Dependent Variable: General Expertise

\begin{tabular}{|l|r|r|r|r|r|r|}
\hline Source & $\begin{array}{c}\text { Type III Sum } \\
\text { of Squares }\end{array}$ & df & Mean Square & \multicolumn{1}{|c|}{ F } & \multicolumn{1}{c|}{ Sig. } & $\begin{array}{c}\text { Partial Eta } \\
\text { Squared }\end{array}$ \\
\hline Corrected Model & $29.777^{2}$ & 15 & 1.985 & 3.201 & .000 & .185 \\
Intercept & 1174.432 & 1 & 1174.432 & 1893.453 & .000 & .900 \\
Sex & 6.342 & 1 & 6.342 & 10.224 & .002 & .046 \\
Afield & 4.188 & 1 & 4.188 & 6.752 & .010 & .031 \\
Experien & 5.727 & 3 & 1.909 & 3.078 & .029 & .042 \\
Sex *Afield & 5.575 & 1 & 5.575 & 8.989 & .003 & .041 \\
Sex * Experien & .713 & 3 & .238 & .383 & .765 & .005 \\
Afield * Experien & 6.588 & 3 & 2.196 & 3.540 & .016 & .048 \\
Sex *Afield * Experien & .767 & 3 & .256 & .412 & .744 & .006 \\
Error & 130.875 & 211 & .620 & & & \\
Total & 1736.000 & 227 & & & & \\
Corrected Total & 160.652 & 226 & & & & \\
\hline
\end{tabular}

a. $\mathrm{R}$ Squared $=.185$ (Adjusted $\mathrm{R}$ Squared $=.127$ )

\section{Estimated Marginal Means}

\section{Grand Mean}

Dependent Variable: General Expertise

\begin{tabular}{|c|r|r|r|}
\hline & & \multicolumn{2}{|c|}{$95 \%$ Confidence Interval } \\
\cline { 3 - 4 } Mean & Std. Error & Lower Bound & Upper Bound \\
\hline 2.593 & .060 & 2.476 & 2.711 \\
\hline
\end{tabular}

\section{Sex}




\section{Estimates}

Dependent Variable: General Expertise

\begin{tabular}{|l|r|r|r|r|}
\hline & & & \multicolumn{2}{|c|}{$95 \%$ Confidence Interval } \\
\cline { 4 - 5 } Sex & Mean & Std. Error & Lower Bound & Upper Bound \\
\hline male & 2.784 & .092 & 2.602 & 2.966 \\
female & 2.403 & .075 & 2.254 & 2.551 \\
\hline
\end{tabular}

\section{Pairwise Comparisons}

Dependent Variable: General Expertise

\begin{tabular}{|c|c|c|c|c|c|c|}
\hline \multirow[b]{2}{*}{ (I) Sex } & \multirow[b]{2}{*}{ (J) Sex } & \multirow{2}{*}{$\begin{array}{c}\text { Mean } \\
\text { Difference (I-J) }\end{array}$} & \multirow[b]{2}{*}{ Std. Error } & \multirow[b]{2}{*}{ Sig. ${ }^{a}$} & \multicolumn{2}{|c|}{$\begin{array}{c}\text { 95\% Confidence Interval for } \\
\text { Difference }\end{array}$} \\
\hline & & & & & Lower Bound & Upper Bound \\
\hline male & female & $.381^{*}$ & .119 & .002 & .146 & .616 \\
\hline female & male & $-.381^{*}$ & .119 & .002 & -.616 & -.146 \\
\hline
\end{tabular}

Based on estimated marginal means

*. The mean difference is significant at the .05 level.

a. Adjustment for multiple comparisons: Least Significant Difference (equivalent to no adjustments).

\section{Univariate Tests}

Dependent Variable: General Expertise

\begin{tabular}{|l|r|r|r|r|r|r|}
\hline & $\begin{array}{c}\text { Sum of } \\
\text { Squares }\end{array}$ & df & Mean Square & F & Sig. & $\begin{array}{c}\text { Partial Eta } \\
\text { Squared }\end{array}$ \\
\hline Contrast & 6.342 & 1 & 6.342 & 10.224 & .002 & .046 \\
Error & 130.875 & 211 & .620 & & & \\
\hline
\end{tabular}

The $\mathrm{F}$ tests the effect of Sex. This test is based on the linearly independent pairwise compi among the estimated marginal means.

\section{Academic field}

\section{Estimates}

Dependent Variable: General Expertise

\begin{tabular}{|l|r|r|r|r|}
\hline & & & \multicolumn{2}{|c|}{$95 \%$ Confidence Interval } \\
\cline { 4 - 5 } Academic field & Mean & Std. Error & Lower Bound & Upper Bound \\
\hline Scientific & 2.748 & .079 & 2.592 & 2.904 \\
Humanities & 2.438 & .089 & 2.263 & 2.614 \\
\hline
\end{tabular}


Pairwise Comparisons

Dependent Variable: General Expertise

\begin{tabular}{|c|c|c|c|c|c|c|}
\hline \multirow[b]{2}{*}{ (I) Academic field } & \multirow[b]{2}{*}{ (J) Academic field } & \multirow{2}{*}{$\begin{array}{c}\text { Mean } \\
\text { Difference (I-J) }\end{array}$} & \multirow[b]{2}{*}{ Std. Error } & \multirow[b]{2}{*}{ Sig. ${ }^{a}$} & \multicolumn{2}{|c|}{$\begin{array}{c}\text { 95\% Confidence Interval for } \\
\text { Difference } \\
\end{array}$} \\
\hline & & & & & Lower Bound & Upper Bound \\
\hline scientific & Humanities & $.310^{*}$ & .119 & .010 & .075 & .545 \\
\hline Humanities & scientific & $-.310^{*}$ & .119 & .010 & -.545 & -.075 \\
\hline
\end{tabular}

Based on estimated marginal means

*. The mean difference is significant at the .05 level.

a. Adjustment for multiple comparisons: Least Significant Difference (equivalent to no adjustments).

\section{Univariate Tests}

Dependent Variable: General Expertise

\begin{tabular}{|l|r|r|r|r|r|r|}
\hline & $\begin{array}{c}\text { Sum of } \\
\text { Squares }\end{array}$ & df & Mean Square & F & Sig. & $\begin{array}{c}\text { Partial Eta } \\
\text { Squared }\end{array}$ \\
\hline Contrast & 4.188 & 1 & 4.188 & 6.752 & .010 & .031 \\
Error & 130.875 & 211 & .620 & & & \\
\hline
\end{tabular}

The $\mathrm{F}$ tests the effect of Academic field. This test is based on the linearly independent pair comparisons among the estimated marginal means.

\section{Experience}

\section{Estimates}

Dependent Variable: General Expertise

\begin{tabular}{|l|r|r|r|r|}
\hline & & & \multicolumn{2}{|c|}{$95 \%$ Confidence Interval } \\
\cline { 4 - 5 } Experience & Mean & Std. Error & Lower Bound & Upper Bound \\
\hline $0-5$ & 2.284 & .122 & 2.044 & 2.524 \\
$6-10$ & 2.666 & .131 & 2.408 & 2.925 \\
$11-15$ & 2.792 & .131 & 2.533 & 3.050 \\
$15+$ & 2.630 & .087 & 2.459 & 2.802 \\
\hline
\end{tabular}


Pairwise Comparisons

Dependent Variable: General Expertise

\begin{tabular}{|c|c|c|c|c|c|c|}
\hline & & Mean & & & $\begin{array}{r}95 \% \text { Confider } \\
\text { Diffe }\end{array}$ & $\begin{array}{l}\text { ce Interval for } \\
\text { ence }\end{array}$ \\
\hline (I) Experience & (J) Experience & Difference (I-J) & Std. Error & Sig. ${ }^{a}$ & Lower Bound & Upper Bound \\
\hline $0-5$ & $6-10$ & $-.382^{*}$ & .179 & .034 & -.735 & -.029 \\
\hline & $11-15$ & $-.508^{*}$ & .179 & .005 & -.860 & -.155 \\
\hline & $15+$ & $-.346^{*}$ & .150 & .022 & -.641 & -.051 \\
\hline $6-10$ & $0-5$ & $.382^{*}$ & .179 & .034 & .029 & .735 \\
\hline & $11-15$ & -.125 & .186 & .501 & -.491 & .241 \\
\hline & $15+$ & .036 & .158 & .819 & -.274 & .347 \\
\hline $11-15$ & $0-5$ & $.508^{*}$ & .179 & .005 & .155 & .860 \\
\hline & $6-10$ & .125 & .186 & .501 & -.241 & .491 \\
\hline & $15+$ & .161 & .157 & .307 & -.149 & .471 \\
\hline $15+$ & $0-5$ & $.346^{*}$ & .150 & .022 & .051 & .641 \\
\hline & $6-10$ & -.036 & .158 & .819 & -.347 & .274 \\
\hline & $11-15$ & -.161 & .157 & .307 & -.471 & .149 \\
\hline
\end{tabular}

Based on estimated marginal means

*. The mean difference is significant at the .05 level.

a. Adjustment for multiple comparisons: Least Significant Difference (equivalent to no adjustments).

\section{Univariate Tests}

Dependent Variable: General Expertise

\begin{tabular}{|l|r|r|r|r|r|r|}
\hline & $\begin{array}{c}\text { Sum of } \\
\text { Squares }\end{array}$ & \multicolumn{1}{c|}{ df } & Mean Square & F & Sig. & $\begin{array}{c}\text { Partial Eta } \\
\text { Squared }\end{array}$ \\
\hline Contrast & 5.727 & 3 & 1.909 & 3.078 & .029 & .042 \\
Error & 130.875 & 211 & .620 & & & \\
\hline
\end{tabular}

The $\mathrm{F}$ tests the effect of Experience. This test is based on the linearly independent pairwis comparisons among the estimated marginal means.

\section{Sex * Academic field}

Dependent Variable: General Expertise

\begin{tabular}{|ll|r|r|r|r|}
\hline & & & & \multicolumn{2}{|c|}{$95 \%$ Confidence Interval } \\
\cline { 5 - 6 } Sex & Academic field & Mean & Std. Error & Lower Bound & Upper Bound \\
\hline male & scientific & 2.760 & .124 & 2.516 & 3.004 \\
& Humanities & 2.808 & .137 & 2.537 & 3.078 \\
\hline female & scientific & 2.736 & .099 & 2.541 & 2.932 \\
& Humanities & 2.069 & .113 & 1.846 & 2.292 \\
\hline
\end{tabular}




\section{Sex * Experience}

Dependent Variable: General Expertise

\begin{tabular}{|ll|r|r|r|r|}
\hline & & & \multicolumn{2}{|c|}{$95 \%$ Confidence Interval } \\
\cline { 5 - 6 } Sex & Experience & Mean & Std. Error & Lower Bound & Upper Bound \\
\hline male & $0-5$ & 2.513 & .177 & 2.164 & 2.861 \\
& $6-10$ & 2.777 & .207 & 2.368 & 3.185 \\
& $11-15$ & 2.950 & .216 & 2.525 & 3.375 \\
& $15+$ & 2.895 & .126 & 2.647 & 3.144 \\
\hline female & $0-5$ & 2.056 & .167 & 1.726 & 2.385 \\
& $6-10$ & 2.556 & .161 & 2.238 & 2.874 \\
& $11-15$ & 2.633 & .149 & 2.339 & 2.927 \\
$15+$ & 2.366 & .120 & 2.129 & 2.602 \\
\hline
\end{tabular}

\section{Academic field * Experience}

Dependent Variable: General Expertise

\begin{tabular}{|ll|r|r|r|r|}
\hline \multirow{2}{*}{ Academic field } & Experience & Mean & Std. Error & \multicolumn{2}{|c|}{ 95\% Confidence Interval } \\
\cline { 5 - 6 } & $0-5$ & 2.747 & .133 & 2.484 & 3.009 \\
& $6-10$ & 2.564 & .212 & 2.145 & 2.982 \\
& $11-15$ & 2.950 & .166 & 2.623 & 3.277 \\
& $15+$ & 2.732 & .101 & 2.532 & 2.931 \\
\hline Humanities & $0-5$ & 1.821 & .204 & 1.420 & 2.223 \\
& $6-10$ & 2.769 & .154 & 2.465 & 3.074 \\
& $11-15$ & 2.633 & .203 & 2.232 & 3.034 \\
& $15+$ & 2.529 & .142 & 2.250 & 2.808 \\
\hline
\end{tabular}




\section{Sex * Academic field * Experience}

Dependent Variable: General Expertise

\begin{tabular}{|c|c|c|c|c|c|c|}
\hline \multirow{2}{*}{ Sex } & \multirow[b]{2}{*}{ Academic field } & \multirow[b]{2}{*}{ Experience } & \multirow[b]{2}{*}{ Mean } & \multirow[b]{2}{*}{ Std. Error } & \multicolumn{2}{|c|}{$95 \%$ Confidence Interval } \\
\hline & & & & & Lower Bound & Upper Bound \\
\hline \multirow[t]{8}{*}{ male } & scientific & $0-5$ & 2.882 & .191 & 2.506 & 3.259 \\
\hline & & $6-10$ & 2.400 & .352 & 1.706 & 3.094 \\
\hline & & $11-15$ & 2.900 & .249 & 2.409 & 3.391 \\
\hline & & $15+$ & 2.857 & .149 & 2.564 & 3.151 \\
\hline & Humanities & $0-5$ & 2.143 & .298 & 1.556 & 2.730 \\
\hline & & $6-10$ & 3.154 & .218 & 2.723 & 3.584 \\
\hline & & $11-15$ & 3.000 & .352 & 2.306 & 3.694 \\
\hline & & $15+$ & 2.933 & .203 & 2.532 & 3.334 \\
\hline \multirow[t]{8}{*}{ female } & scientific & $0-5$ & 2.611 & .186 & 2.245 & 2.977 \\
\hline & & $6-10$ & 2.727 & .237 & 2.259 & 3.195 \\
\hline & & $11-15$ & 3.000 & .218 & 2.569 & 3.431 \\
\hline & & $15+$ & 2.606 & .137 & 2.336 & 2.876 \\
\hline & Humanities & $0-5$ & 1.500 & .278 & .951 & 2.049 \\
\hline & & $6-10$ & 2.385 & .218 & 1.954 & 2.815 \\
\hline & & $11-15$ & 2.267 & .203 & 1.866 & 2.668 \\
\hline & & $15+$ & 2.125 & .197 & 1.737 & 2.513 \\
\hline
\end{tabular}

\section{Post Hoc Tests}

\section{Experience}

\section{Multiple Comparisons}

Dependent Variable: General Expertise

Scheffe

\begin{tabular}{|c|c|c|c|c|c|c|}
\hline \multirow[b]{2}{*}{ (I) Experience } & \multirow[b]{2}{*}{ (J) Experience } & \multirow{2}{*}{$\begin{array}{c}\text { Mean } \\
\text { Difference (I-J) }\end{array}$} & \multirow[b]{2}{*}{ Std. Error } & \multirow[b]{2}{*}{ Sig. } & \multicolumn{2}{|c|}{ 95\% Confidence Interval } \\
\hline & & & & & Lower Bound & Upper Bound \\
\hline \multirow[t]{3}{*}{$0-5$} & $6-10$ & -.25 & .165 & .499 & -.72 & .21 \\
\hline & $11-15$ & -.26 & .164 & .470 & -.72 & .20 \\
\hline & $15+$ & -.19 & .138 & .588 & -.58 & .20 \\
\hline \multirow[t]{3}{*}{$6-10$} & $0-5$ & .25 & .165 & .499 & -.21 & .72 \\
\hline & $11-15$ & -.01 & .171 & 1.000 & -.49 & .47 \\
\hline & $15+$ & .06 & .147 & .981 & -.35 & .48 \\
\hline \multirow[t]{3}{*}{$11-15$} & $0-5$ & .26 & .164 & .470 & -.20 & .72 \\
\hline & $6-10$ & .01 & .171 & 1.000 & -.47 & .49 \\
\hline & $15+$ & .07 & .145 & .974 & -.34 & .48 \\
\hline \multirow[t]{3}{*}{$15+$} & $0-5$ & .19 & .138 & .588 & -.20 & .58 \\
\hline & $6-10$ & -.06 & .147 & .981 & -.48 & .35 \\
\hline & $11-15$ & -.07 & .145 & .974 & -.48 & .34 \\
\hline
\end{tabular}

Based on observed means. 


\section{Homogeneous Subsets}

\section{General Expertise}

Scheffe $\mathrm{a}^{\mathrm{a}, \mathrm{b}, \mathrm{c}}$

\begin{tabular}{|l|r|r|}
\hline & & Subset \\
\cline { 3 - 3 } Experience & $\mathrm{N}$ & 1 \\
\hline $0-5$ & 50 & 2.46 \\
$15+$ & 92 & 2.65 \\
$6-10$ & 42 & 2.71 \\
$11-15$ & 43 & 2.72 \\
Sig. & & .423 \\
\hline
\end{tabular}

Means for groups in homogeneous subsets are displayed.

Based on Type III Sum of Squares

The error term is Mean Square(Error) $=.620$.

a. Uses Harmonic Mean Sample Size $=51.325$.

b. The group sizes are unequal. The harmonic mean of the group sizes is used. Type I error levels are not guaranteed.

c. Alpha $=.05$.

\section{Profile Plots}


Estimated Marginal Means of General Expertise

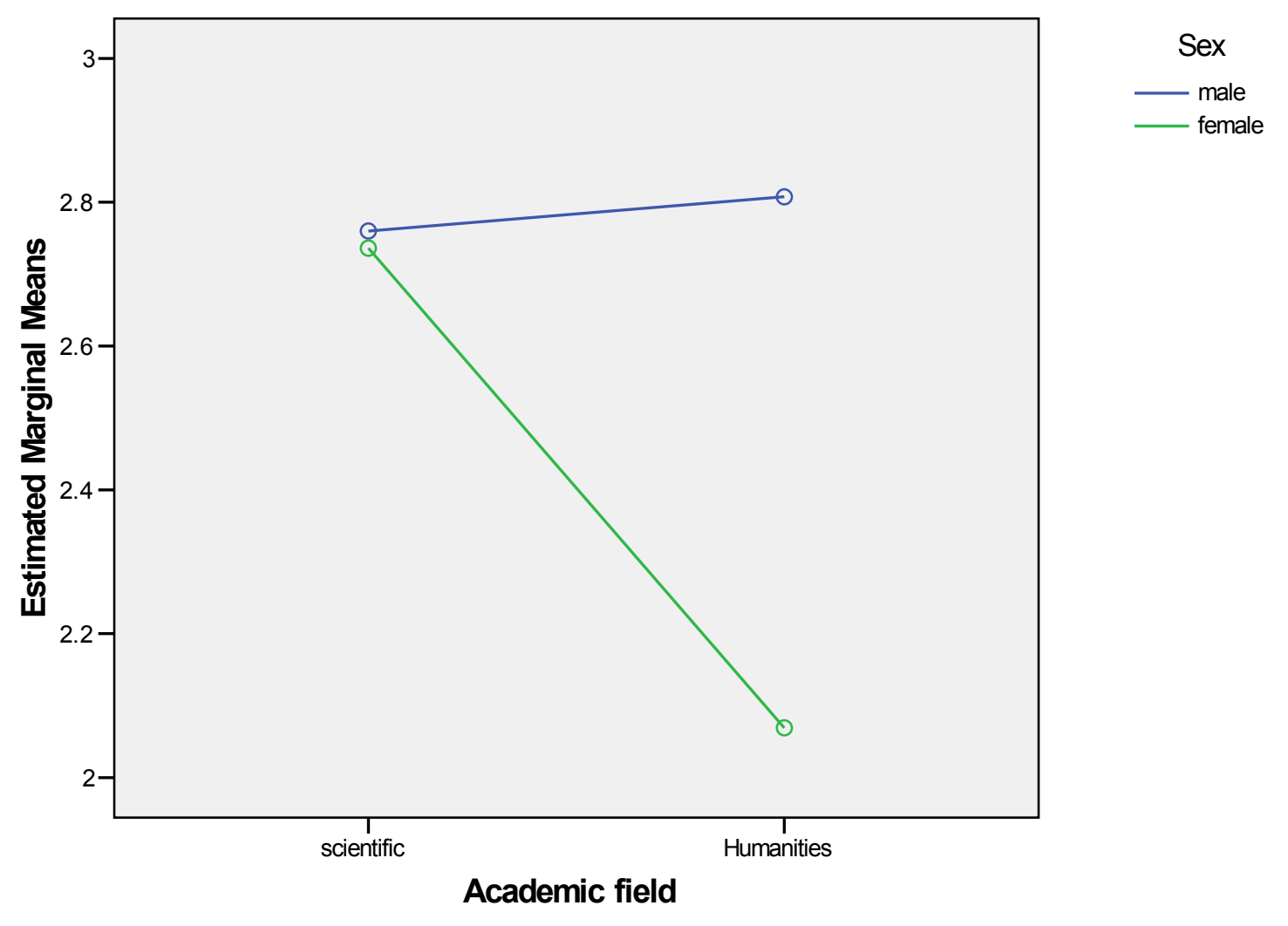


Estimated Marginal Means of General Expertise

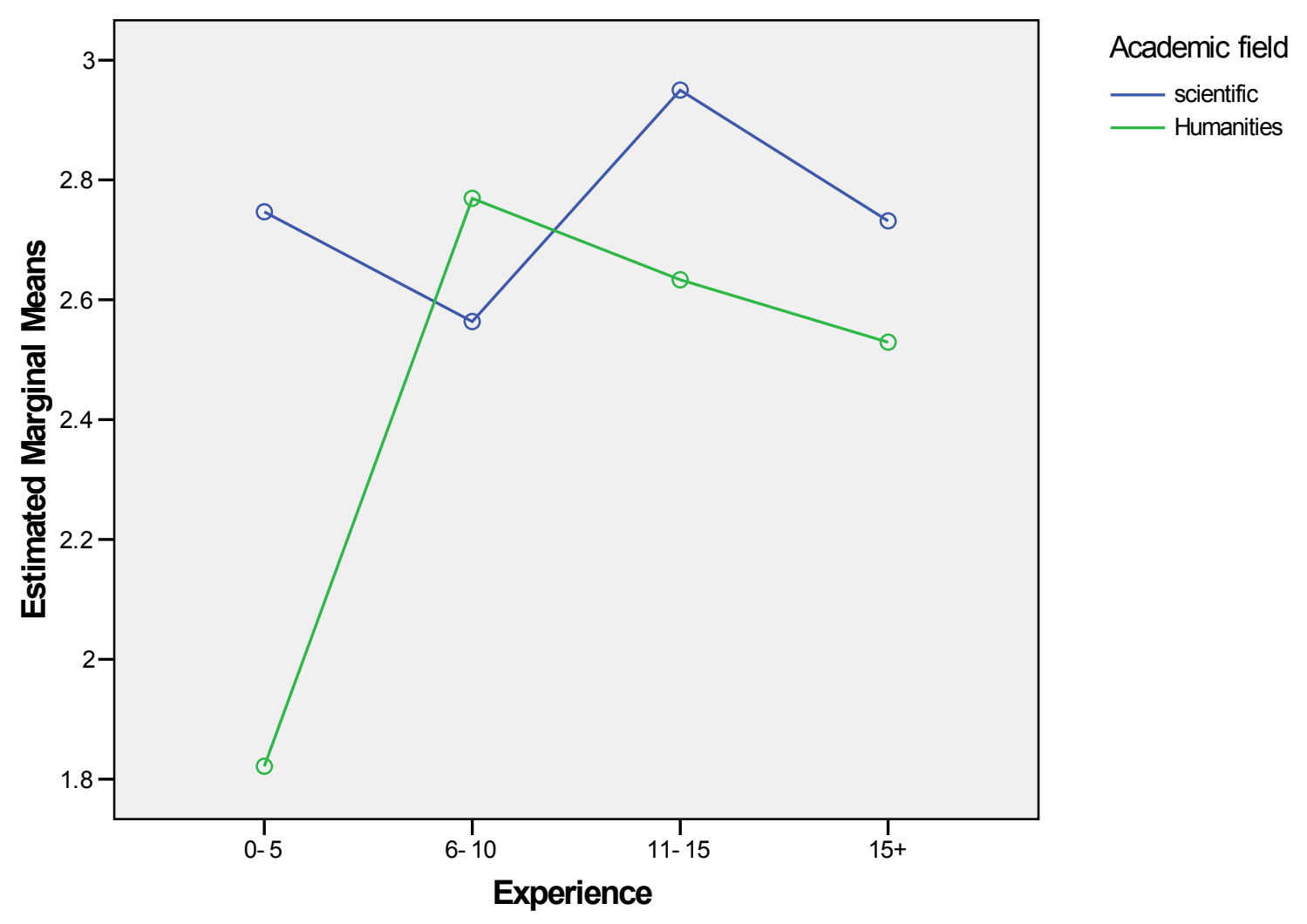


Appendix H: 3-way Factorial ANOVA for Specific Expertise Univariate Analysis of Variance

Between-Subjects Factors

\begin{tabular}{|ll|l|r|}
\hline & & Value Label & $\mathrm{N}$ \\
\hline Sex & 1 & male & 100 \\
& 2 & female & 127 \\
Academic & 1 & scientific & 135 \\
field & 2 & Humanities & 92 \\
Experience & 0 & $0-5$ & 50 \\
& 1 & $6-10$ & 42 \\
& 2 & $11-15$ & 43 \\
& 3 & $15+$ & 92 \\
\hline
\end{tabular}


Descriptive Statistics

Dependent Variable: SPECIFIC EXPERTISE

\begin{tabular}{|c|c|c|c|c|c|}
\hline Sex & Academic field & Experience & Mean & Std. Deviation & $\mathrm{N}$ \\
\hline \multirow[t]{15}{*}{ male } & \multirow[t]{5}{*}{ scientific } & $0-5$ & 2.71 & .985 & 17 \\
\hline & & $6-10$ & 2.00 & .707 & 5 \\
\hline & & $11-15$ & 2.90 & .994 & 10 \\
\hline & & $15+$ & 2.54 & .838 & 28 \\
\hline & & Total & 2.60 & .906 & 60 \\
\hline & \multirow[t]{5}{*}{ Humanities } & $0-5$ & 2.14 & 1.464 & 7 \\
\hline & & $6-10$ & 3.23 & .832 & 13 \\
\hline & & $11-15$ & 3.00 & 1.000 & 5 \\
\hline & & $15+$ & 2.33 & .976 & 15 \\
\hline & & Total & 2.68 & 1.095 & 40 \\
\hline & \multirow[t]{5}{*}{ Total } & $0-5$ & 2.54 & 1.141 & 24 \\
\hline & & $6-10$ & 2.89 & .963 & 18 \\
\hline & & $11-15$ & 2.93 & .961 & 15 \\
\hline & & $15+$ & 2.47 & .882 & 43 \\
\hline & & Total & 2.63 & .981 & 100 \\
\hline \multirow[t]{15}{*}{ female } & \multirow[t]{5}{*}{ scientific } & $0-5$ & 2.22 & .943 & 18 \\
\hline & & $6-10$ & 2.45 & 1.036 & 11 \\
\hline & & $11-15$ & 2.23 & .599 & 13 \\
\hline & & $15+$ & 2.36 & .859 & 33 \\
\hline & & Total & 2.32 & .857 & 75 \\
\hline & \multirow[t]{5}{*}{ Humanities } & $0-5$ & 1.38 & .518 & 8 \\
\hline & & $6-10$ & 2.15 & .689 & 13 \\
\hline & & $11-15$ & 1.67 & .900 & 15 \\
\hline & & $15+$ & 1.69 & 1.078 & 16 \\
\hline & & Total & 1.75 & .883 & 52 \\
\hline & \multirow[t]{5}{*}{ Total } & $0-5$ & 1.96 & .916 & 26 \\
\hline & & $6-10$ & 2.29 & .859 & 24 \\
\hline & & $11-15$ & 1.93 & .813 & 28 \\
\hline & & $15+$ & 2.14 & .979 & 49 \\
\hline & & Total & 2.09 & .909 & 127 \\
\hline \multirow[t]{15}{*}{ Total } & \multirow[t]{5}{*}{ scientific } & $0-5$ & 2.46 & .980 & 35 \\
\hline & & $6-10$ & 2.31 & .946 & 16 \\
\hline & & $11-15$ & 2.52 & .846 & 23 \\
\hline & & $15+$ & 2.44 & .847 & 61 \\
\hline & & Total & 2.44 & .887 & 135 \\
\hline & \multirow[t]{5}{*}{ Humanities } & $0-5$ & 1.73 & 1.100 & 15 \\
\hline & & $6-10$ & 2.69 & .928 & 26 \\
\hline & & $11-15$ & 2.00 & 1.076 & 20 \\
\hline & & $15+$ & 2.00 & 1.065 & 31 \\
\hline & & Total & 2.15 & 1.079 & 92 \\
\hline & \multirow[t]{5}{*}{ Total } & $0-5$ & 2.24 & 1.061 & 50 \\
\hline & & $6-10$ & 2.55 & .942 & 42 \\
\hline & & $11-15$ & 2.28 & .984 & 43 \\
\hline & & $15+$ & 2.29 & .944 & 92 \\
\hline & & Total & 2.33 & .977 & 227 \\
\hline
\end{tabular}




\section{Levene's Test of Equality of Error Variancess}

Dependent Variable: SPECIFIC EXPERTISE

\begin{tabular}{|l|l|l|l|}
\hline $\mathrm{F}$ & $\mathrm{df} 1$ & $\mathrm{df} 2$ & Sig. \\
\hline 1.821 & 15 & 211 & .033 \\
\hline
\end{tabular}

Tests the null hypothesis that the error variance of the dependt variable is equal across groups.

a. Design: Intercept+Sex+Afield+Experien+Sex *Afield+Se:

${ }^{*}$ Experien+Afield * Experien+Sex * Afield * Experien

Tests of Between-Subjects Effects

Dependent Variable: SPECIFIC EXPERTISE

\begin{tabular}{|l|r|r|r|r|r|r|}
\hline Source & $\begin{array}{c}\text { Type III Sum } \\
\text { of Squares }\end{array}$ & df & Mean Square & \multicolumn{1}{|c|}{ F } & \multicolumn{1}{c|}{ Sig. } & $\begin{array}{c}\text { Partial Eta } \\
\text { Squared }\end{array}$ \\
\hline Corrected Model & $41.864^{\mathrm{a}}$ & 15 & 2.791 & 3.384 & .000 & .194 \\
Intercept & 934.122 & 1 & 934.122 & 1132.676 & .000 & .843 \\
Sex & 15.035 & 1 & 15.035 & 18.230 & .000 & .080 \\
Afield & 2.267 & 1 & 2.267 & 2.749 & .099 & .013 \\
Experien & 3.580 & 3 & 1.193 & 1.447 & .230 & .020 \\
Sex * Afield & 5.951 & 1 & 5.951 & 7.216 & .008 & .033 \\
Sex * Experien & 2.816 & 3 & .939 & 1.138 & .335 & .016 \\
Afield * Experien & 7.417 & 3 & 2.472 & 2.998 & .032 & .041 \\
Sex * Afield * Experien & 2.255 & 3 & .752 & .911 & .436 & .013 \\
Error & 174.012 & 211 & .825 & & & \\
Total & 1444.000 & 227 & & & & \\
Corrected Total & 215.877 & 226 & & & & \\
\hline
\end{tabular}

a. $\mathrm{R}$ Squared $=.194$ (Adjusted $\mathrm{R}$ Squared $=.137$ )

\section{Estimated Marginal Means}

\section{Grand Mean}

Dependent Variable: SPECIFIC EXPERTISE

\begin{tabular}{|c|r|r|r|}
\hline & & \multicolumn{2}{|c|}{$95 \%$ Confidence Interval } \\
\cline { 3 - 4 } Mean & Std. Error & Lower Bound & Upper Bound \\
\hline 2.313 & .069 & 2.177 & 2.448 \\
\hline
\end{tabular}

\section{Sex}




\section{Estimates}

Dependent Variable: SPECIFIC EXPERTISE

\begin{tabular}{|l|r|r|r|r|}
\hline & & & \multicolumn{2}{|c|}{$95 \%$ Confidence Interval } \\
\cline { 4 - 5 } Sex & Mean & Std. Error & Lower Bound & Upper Bound \\
\hline male & 2.606 & .107 & 2.396 & 2.816 \\
female & 2.019 & .087 & 1.848 & 2.190 \\
\hline
\end{tabular}

\section{Pairwise Comparisons}

Dependent Variable: SPECIFIC EXPERTISE

\begin{tabular}{|c|c|c|c|c|c|c|}
\hline \multirow[b]{2}{*}{ (I) Sex } & \multirow[b]{2}{*}{ (J) Sex } & \multirow{2}{*}{$\begin{array}{c}\text { Mean } \\
\text { Difference (I-J) }\end{array}$} & \multirow[b]{2}{*}{ Std. Error } & \multirow[b]{2}{*}{ Sig. ${ }^{a}$} & \multicolumn{2}{|c|}{$\begin{array}{c}\text { 95\% Confidence Interval for } \\
\text { Difference }\end{array}$} \\
\hline & & & & & Lower Bound & Upper Bound \\
\hline male & female & $.587^{*}$ & .137 & .000 & .316 & .858 \\
\hline female & male & $-.587^{*}$ & .137 & .000 & -.858 & -.316 \\
\hline
\end{tabular}

Based on estimated marginal means

*. The mean difference is significant at the .05 level.

a. Adjustment for multiple comparisons: Least Significant Difference (equivalent to no adjustments).

\section{Univariate Tests}

Dependent Variable: SPECIFIC EXPERTISE

\begin{tabular}{|l|r|r|r|r|r|r|}
\hline & $\begin{array}{c}\text { Sum of } \\
\text { Squares }\end{array}$ & $\mathrm{df}$ & Mean Square & $\mathrm{F}$ & \multicolumn{1}{c|}{ Sig. } & $\begin{array}{c}\text { Partial Eta } \\
\text { Squared }\end{array}$ \\
\hline Contrast & 15.035 & 1 & 15.035 & 18.230 & .000 & .080 \\
Error & 174.012 & 211 & .825 & & & \\
\hline
\end{tabular}

The $\mathrm{F}$ tests the effect of Sex. This test is based on the linearly independent pairwise compi among the estimated marginal means.

\section{Academic field}

\section{Estimates}

Dependent Variable: SPECIFIC EXPERTISE

\begin{tabular}{|l|r|r|r|r|}
\hline & & & \multicolumn{2}{|c|}{$95 \%$ Confidence Interval } \\
\cline { 4 - 5 } Academic field & Mean & Std. Error & Lower Bound & Upper Bound \\
\hline Scientific & 2.427 & .091 & 2.246 & 2.607 \\
Humanities & 2.199 & .103 & 1.996 & 2.401 \\
\hline
\end{tabular}




\section{Pairwise Comparisons}

Dependent Variable: SPECIFIC EXPERTISE

\begin{tabular}{|c|c|c|c|c|c|c|}
\hline \multirow[b]{2}{*}{ (I) Academic field } & \multirow[b]{2}{*}{ (J) Academic field } & \multirow{2}{*}{$\begin{array}{c}\text { Mean } \\
\text { Difference (I-J) }\end{array}$} & \multirow[b]{2}{*}{ Std. Error } & \multirow[b]{2}{*}{ Sig. $^{a}$} & \multicolumn{2}{|c|}{$\begin{array}{c}\text { 95\% Confidence Interval for } \\
\text { Difference }^{\mathrm{a}}\end{array}$} \\
\hline & & & & & Lower Bound & Upper Bound \\
\hline scientific & Humanities & .228 & .137 & .099 & -.043 & .499 \\
\hline Humanities & scientific & -.228 & .137 & .099 & -.499 & .043 \\
\hline
\end{tabular}

Based on estimated marginal means

a. Adjustment for multiple comparisons: Least Significant Difference (equivalent to no adjustments).

\section{Univariate Tests}

Dependent Variable: SPECIFIC EXPERTISE

\begin{tabular}{|l|r|r|r|r|r|r|}
\hline & $\begin{array}{c}\text { Sum of } \\
\text { Squares }\end{array}$ & \multicolumn{1}{c|}{$\mathrm{df}$} & Mean Square & $\mathrm{F}$ & \multicolumn{1}{c|}{ Sig. } & $\begin{array}{c}\text { Partial Eta } \\
\text { Squared }\end{array}$ \\
\hline Contrast & 2.267 & 1 & 2.267 & 2.749 & .099 & .013 \\
Error & 174.012 & 211 & .825 & & & \\
\hline
\end{tabular}

The $\mathrm{F}$ tests the effect of Academic field. This test is based on the linearly independent pair comparisons among the estimated marginal means.

\section{Experience}

\section{Estimates}

Dependent Variable: SPECIFIC EXPERTISE

\begin{tabular}{|l|c|r|r|r|}
\hline & & & \multicolumn{2}{|c|}{ 95\% Confidence Interval } \\
\cline { 4 - 5 } Experience & Mean & Std. Error & Lower Bound & Upper Bound \\
\hline $0-5$ & 2.111 & .140 & 1.835 & 2.388 \\
$6-10$ & 2.460 & .151 & 2.161 & 2.758 \\
$11-15$ & 2.449 & .151 & 2.151 & 2.747 \\
$15+$ & 2.230 & .100 & 2.032 & 2.428 \\
\hline
\end{tabular}


Pairwise Comparisons

Dependent Variable: SPECIFIC EXPERTISE

\begin{tabular}{|c|c|c|c|c|c|c|}
\hline & & Mean & & & $\begin{array}{r}\text { 95\% Confider } \\
\text { Diffe }\end{array}$ & $\begin{array}{l}\text { ce Interval for } \\
\text { ence }\end{array}$ \\
\hline (I) Experience & (J) Experience & Difference (I-J) & Std. Error & Sig. ${ }^{a}$ & Lower Bound & Upper Bound \\
\hline $0-5$ & $6-10$ & -.348 & .206 & .093 & -.755 & .059 \\
\hline & $11-15$ & -.338 & .206 & .103 & -.745 & .069 \\
\hline & $15+$ & -.119 & .173 & .493 & -.459 & .222 \\
\hline $6-10$ & $0-5$ & .348 & .206 & .093 & -.059 & .755 \\
\hline & $11-15$ & .010 & .214 & .961 & -.411 & .432 \\
\hline & $15+$ & .230 & .182 & .207 & -.128 & .588 \\
\hline $11-15$ & $0-5$ & .338 & .206 & .103 & -.069 & .745 \\
\hline & $6-10$ & -.010 & .214 & .961 & -.432 & .411 \\
\hline & $15+$ & .219 & .181 & .228 & -.138 & .577 \\
\hline $15+$ & $0-5$ & .119 & .173 & .493 & -.222 & .459 \\
\hline & $6-10$ & -.230 & .182 & .207 & -.588 & .128 \\
\hline & $11-15$ & -.219 & .181 & .228 & -.577 & .138 \\
\hline
\end{tabular}

Based on estimated marginal means

a. Adjustment for multiple comparisons: Least Significant Difference (equivalent to no adjustments).

\section{Univariate Tests}

Dependent Variable: SPECIFIC EXPERTISE

\begin{tabular}{|l|r|r|r|r|r|r|}
\hline & $\begin{array}{c}\text { Sum of } \\
\text { Squares }\end{array}$ & \multicolumn{1}{c|}{$\mathrm{df}$} & Mean Square & $\mathrm{F}$ & \multicolumn{1}{c|}{ Sig. } & $\begin{array}{c}\text { Partial Eta } \\
\text { Squared }\end{array}$ \\
\hline Contrast & 3.580 & 3 & 1.193 & 1.447 & .230 & .020 \\
Error & 174.012 & 211 & .825 & & & \\
\hline
\end{tabular}

The $F$ tests the effect of Experience. This test is based on the linearly independent pairwis comparisons among the estimated marginal means.

\section{Sex * Academic field}

Dependent Variable: SPECIFIC EXPERTISE

\begin{tabular}{|ll|r|r|r|r|}
\hline & & & \multicolumn{2}{|c|}{$95 \%$ Confidence Interval } \\
\cline { 5 - 6 } Sex & Academic field & Mean & Std. Error & Lower Bound & Upper Bound \\
\hline male & scientific & 2.535 & .143 & 2.254 & 2.817 \\
& Humanities & 2.677 & .158 & 2.365 & 2.989 \\
\hline female & scientific & 2.318 & .114 & 2.092 & 2.543 \\
& Humanities & 1.721 & .131 & 1.463 & 1.978 \\
\hline
\end{tabular}


6. Sex * Experience

Dependent Variable: SPECIFIC EXPERTISE

\begin{tabular}{|ll|r|r|r|r|}
\hline & & & \multicolumn{2}{|c|}{ 95\% Confidence Interval } \\
\cline { 5 - 6 } Sex & Experience & Mean & Std. Error & Lower Bound & Upper Bound \\
\hline male & $0-5$ & 2.424 & .204 & 2.022 & 2.826 \\
& $6-10$ & 2.615 & .239 & 2.144 & 3.086 \\
& $11-15$ & 2.950 & .249 & 2.460 & 3.440 \\
& $15+$ & 2.435 & .145 & 2.148 & 2.721 \\
\hline female & $0-5$ & 1.799 & .193 & 1.418 & 2.179 \\
& $6-10$ & 2.304 & .186 & 1.938 & 2.671 \\
& $11-15$ & 1.949 & .172 & 1.610 & 2.288 \\
$15+$ & 2.026 & .138 & 1.753 & 2.298 \\
\hline
\end{tabular}

\section{Academic field * Experience}

Dependent Variable: SPECIFIC EXPERTISE

\begin{tabular}{|ll|r|r|r|r|}
\hline & & & \multicolumn{2}{|c|}{ 95\% Confidence Interval } \\
\cline { 5 - 6 } Academic field & Experience & Mean & Std. Error & Lower Bound & Upper Bound \\
\hline scientific & $0-5$ & 2.464 & .154 & 2.161 & 2.767 \\
& $6-10$ & 2.227 & .245 & 1.744 & 2.710 \\
& $11-15$ & 2.565 & .191 & 2.189 & 2.942 \\
& $15+$ & 2.450 & .117 & 2.220 & 2.680 \\
\hline Humanities & $0-5$ & 1.759 & .235 & 1.296 & 2.222 \\
& $6-10$ & 2.692 & .178 & 2.341 & 3.043 \\
& $11-15$ & 2.333 & .234 & 1.871 & 2.796 \\
& $15+$ & 2.010 & .163 & 1.689 & 2.332 \\
\hline
\end{tabular}




\section{Sex * Academic field * Experience}

Dependent Variable: SPECIFIC EXPERTISE

\begin{tabular}{|c|c|c|c|c|c|c|}
\hline \multirow{2}{*}{ Sex } & \multirow[b]{2}{*}{ Academic field } & \multirow[b]{2}{*}{ Experience } & \multirow[b]{2}{*}{ Mean } & \multirow[b]{2}{*}{ Std. Error } & \multicolumn{2}{|c|}{$95 \%$ Confidence Interval } \\
\hline & & & & & Lower Bound & Upper Bound \\
\hline \multirow[t]{8}{*}{ male } & scientific & $0-5$ & 2.706 & .220 & 2.272 & 3.140 \\
\hline & & $6-10$ & 2.000 & .406 & 1.199 & 2.801 \\
\hline & & $11-15$ & 2.900 & .287 & 2.334 & 3.466 \\
\hline & & $15+$ & 2.536 & .172 & 2.197 & 2.874 \\
\hline & Humanities & $0-5$ & 2.143 & .343 & 1.466 & 2.819 \\
\hline & & $6-10$ & 3.231 & .252 & 2.734 & 3.727 \\
\hline & & $11-15$ & 3.000 & .406 & 2.199 & 3.801 \\
\hline & & $15+$ & 2.333 & .234 & 1.871 & 2.796 \\
\hline \multirow[t]{8}{*}{ female } & scientific & $0-5$ & 2.222 & .214 & 1.800 & 2.644 \\
\hline & & $6-10$ & 2.455 & .274 & 1.915 & 2.994 \\
\hline & & $11-15$ & 2.231 & .252 & 1.734 & 2.727 \\
\hline & & $15+$ & 2.364 & .158 & 2.052 & 2.675 \\
\hline & Humanities & $0-5$ & 1.375 & .321 & .742 & 2.008 \\
\hline & & $6-10$ & 2.154 & .252 & 1.657 & 2.650 \\
\hline & & $11-15$ & 1.667 & .234 & 1.204 & 2.129 \\
\hline & & $15+$ & 1.687 & .227 & 1.240 & 2.135 \\
\hline
\end{tabular}

\section{Post Hoc Tests}

\section{Experience}

\section{Multiple Comparisons}

Dependent Variable: SPECIFIC EXPERTISE

Scheffe

\begin{tabular}{|c|c|c|c|c|c|c|}
\hline \multirow[b]{2}{*}{ (I) Experience } & \multirow[b]{2}{*}{ (J) Experience } & \multirow{2}{*}{$\begin{array}{c}\text { Mean } \\
\text { Difference (I-J) }\end{array}$} & \multirow[b]{2}{*}{ Std. Error } & \multirow[b]{2}{*}{ Sig. } & \multicolumn{2}{|c|}{ 95\% Confidence Interval } \\
\hline & & & & & Lower Bound & Upper Bound \\
\hline \multirow[t]{3}{*}{$0-5$} & $6-10$ & -.31 & .190 & .456 & -.84 & .23 \\
\hline & $11-15$ & -.04 & .189 & .998 & -.57 & .49 \\
\hline & $15+$ & -.05 & .160 & .990 & -.50 & .40 \\
\hline \multirow[t]{3}{*}{$6-10$} & $0-5$ & .31 & .190 & .456 & -.23 & .84 \\
\hline & $11-15$ & .27 & .197 & .603 & -.29 & .82 \\
\hline & $15+$ & .25 & .169 & .522 & -.22 & .73 \\
\hline \multirow[t]{3}{*}{$11-15$} & $0-5$ & .04 & .189 & .998 & -.49 & .57 \\
\hline & $6-10$ & -.27 & .197 & .603 & -.82 & .29 \\
\hline & $15+$ & -.01 & .168 & 1.000 & -.49 & .46 \\
\hline \multirow[t]{3}{*}{$15+$} & $0-5$ & .05 & .160 & .990 & -.40 & .50 \\
\hline & $6-10$ & -.25 & .169 & .522 & -.73 & .22 \\
\hline & $11-15$ & .01 & .168 & 1.000 & -.46 & .49 \\
\hline
\end{tabular}

Based on observed means. 


\section{Homogeneous Subsets}

SPECIFIC EXPERTISE

Scheffe ${ }^{\mathrm{a}, \mathrm{b}, \mathrm{c}}$

\begin{tabular}{|l|r|r|}
\hline & & Subset \\
\cline { 3 - 3 } Experience & $\mathrm{N}$ & \multicolumn{1}{|c|}{1} \\
\hline $0-5$ & 50 & 2.24 \\
$11-15$ & 43 & 2.28 \\
$15+$ & 92 & 2.29 \\
$6-10$ & 42 & 2.55 \\
Sig. & & .402 \\
\hline
\end{tabular}

Means for groups in homogeneous subsets are displayed.

Based on Type III Sum of Squares

The error term is Mean Square(Error) $=.825$.

a. Uses Harmonic Mean Sample Size $=51.325$.

b. The group sizes are unequal. The harmonic mean of the group sizes is used. Type I error levels are not guaranteed.

c. Alpha $=.05$.

\section{Profile Plots}

\section{Estimated Marginal Means of SPECIFIC EXPERTISE}

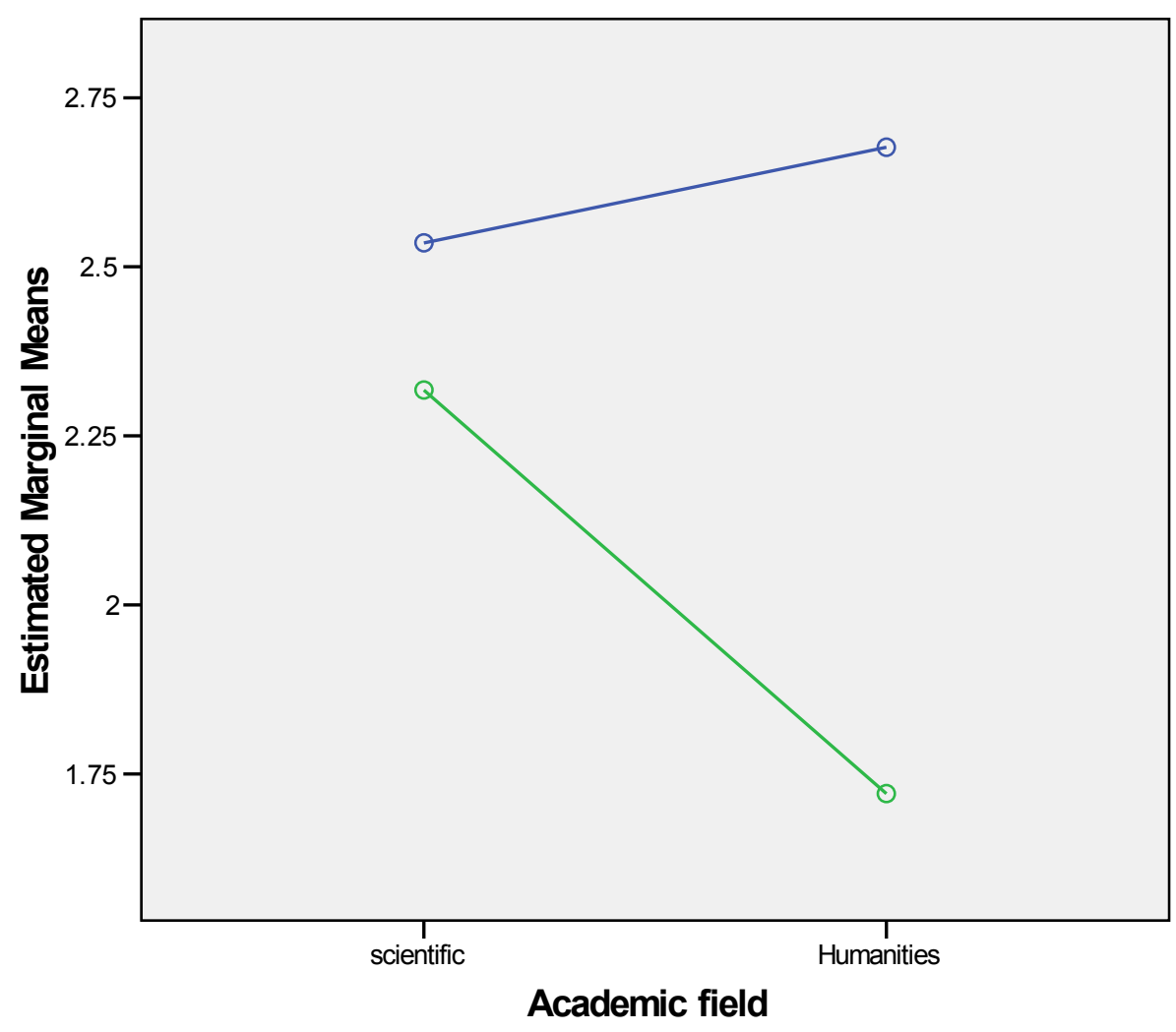

Sex 


\section{Estimated Marginal Means of SPECIFIC EXPERTISE}

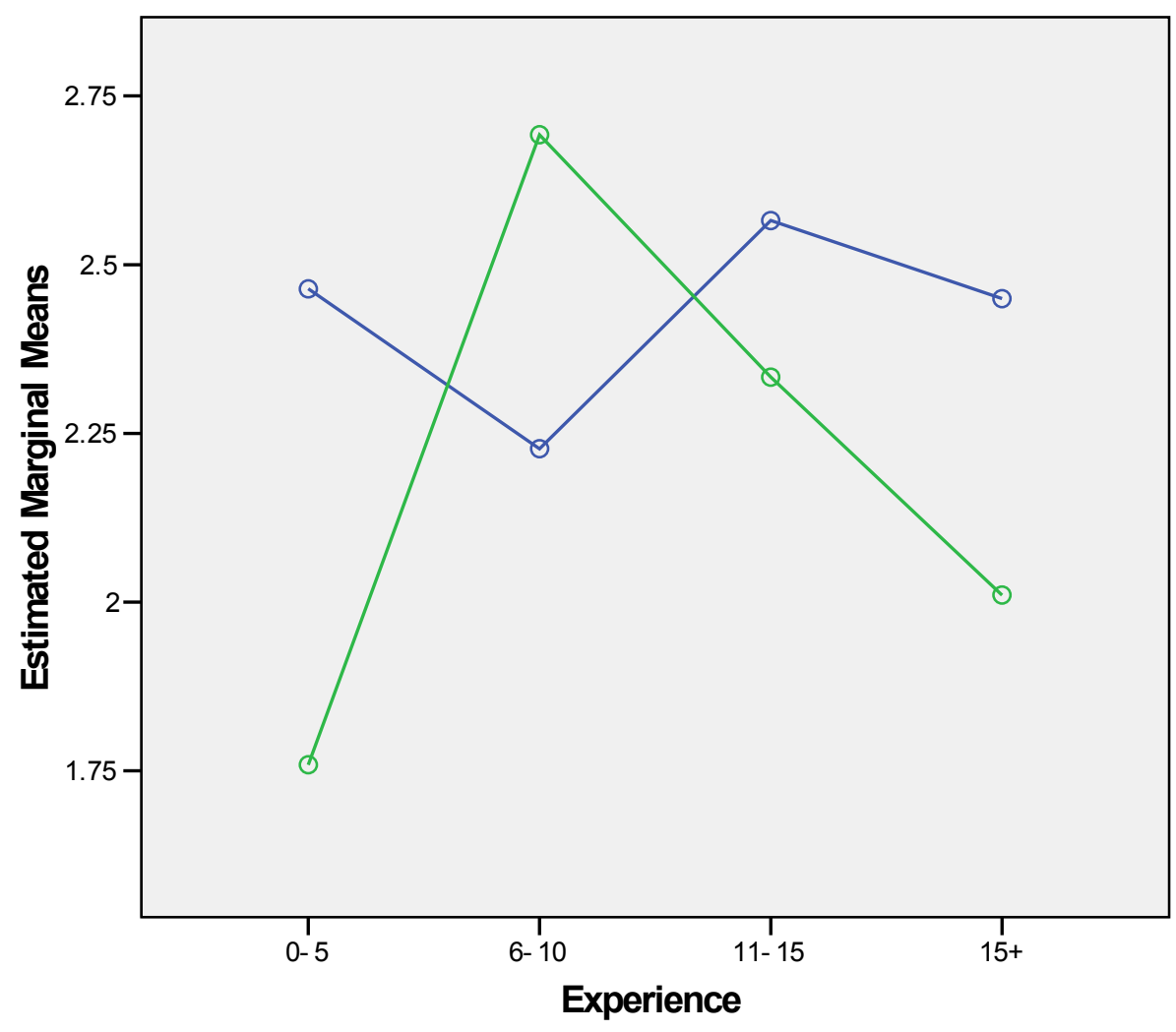

Academic field

- scientific

__ Humanities 
Appendix I: 3-way Factorial ANOVA for Current Use

\section{Univariate Analysis of Variance}

Between-Subjects Factors
\begin{tabular}{|ll|l|r|}
\hline & & Value Label & \multicolumn{1}{|c|}{$\mathrm{N}$} \\
\hline Sex & 1 & male & 100 \\
& 2 & female & 127 \\
Academic & 1 & scientific & 135 \\
field & 2 & Humanities & 92 \\
Experience & 0 & $0-5$ & 50 \\
& 1 & $6-10$ & 42 \\
& 2 & $11-15$ & 43 \\
& 3 & $15+$ & 92 \\
\hline
\end{tabular}


Descriptive Statistics

Dependent Variable: CURRENT USE

\begin{tabular}{|c|c|c|c|c|c|}
\hline Sex & Academic field & Experience & Mean & Std. Deviation & $\mathrm{N}$ \\
\hline \multirow[t]{15}{*}{ male } & \multirow[t]{5}{*}{ scientific } & $0-5$ & 1.59 & .712 & 17 \\
\hline & & $6-10$ & 1.60 & .894 & 5 \\
\hline & & $11-15$ & 1.40 & .516 & 10 \\
\hline & & $15+$ & 1.50 & .577 & 28 \\
\hline & & Total & 1.52 & .624 & 60 \\
\hline & \multirow[t]{5}{*}{ Humanities } & $0-5$ & 1.29 & .756 & 7 \\
\hline & & $6-10$ & 1.69 & .947 & 13 \\
\hline & & $11-15$ & 2.80 & 1.095 & 5 \\
\hline & & $15+$ & 1.60 & .910 & 15 \\
\hline & & Total & 1.73 & .987 & 40 \\
\hline & \multirow[t]{5}{*}{ Total } & $0-5$ & 1.50 & .722 & 24 \\
\hline & & $6-10$ & 1.67 & .907 & 18 \\
\hline & & $11-15$ & 1.87 & .990 & 15 \\
\hline & & $15+$ & 1.53 & .702 & 43 \\
\hline & & Total & 1.60 & .791 & 100 \\
\hline \multirow[t]{15}{*}{ female } & \multirow[t]{5}{*}{ scientific } & $0-5$ & 1.28 & .669 & 18 \\
\hline & & $6-10$ & 1.45 & .688 & 11 \\
\hline & & $11-15$ & 1.31 & .480 & 13 \\
\hline & & $15+$ & 1.58 & .708 & 33 \\
\hline & & Total & 1.44 & .663 & 75 \\
\hline & \multirow[t]{5}{*}{ Humanities } & $0-5$ & .88 & .354 & 8 \\
\hline & & $6-10$ & 1.15 & .555 & 13 \\
\hline & & $11-15$ & 1.00 & .378 & 15 \\
\hline & & $15+$ & 1.00 & .365 & 16 \\
\hline & & Total & 1.02 & .420 & 52 \\
\hline & \multirow[t]{5}{*}{ Total } & $0-5$ & 1.15 & .613 & 26 \\
\hline & & $6-10$ & 1.29 & .624 & 24 \\
\hline & & $11-15$ & 1.14 & .448 & 28 \\
\hline & & $15+$ & 1.39 & .671 & 49 \\
\hline & & Total & 1.27 & .610 & 127 \\
\hline \multirow[t]{15}{*}{ Total } & \multirow[t]{5}{*}{ scientific } & $0-5$ & 1.43 & .698 & 35 \\
\hline & & $6-10$ & 1.50 & .730 & 16 \\
\hline & & $11-15$ & 1.35 & .487 & 23 \\
\hline & & $15+$ & 1.54 & .647 & 61 \\
\hline & & Total & 1.47 & .644 & 135 \\
\hline & \multirow[t]{5}{*}{ Humanities } & $0-5$ & 1.07 & .594 & 15 \\
\hline & & $6-10$ & 1.42 & .809 & 26 \\
\hline & & $11-15$ & 1.45 & .999 & 20 \\
\hline & & $15+$ & 1.29 & .739 & 31 \\
\hline & & Total & 1.33 & .800 & 92 \\
\hline & \multirow[t]{5}{*}{ Total } & $0-5$ & 1.32 & .683 & 50 \\
\hline & & $6-10$ & 1.45 & .772 & 42 \\
\hline & & $11-15$ & 1.40 & .760 & 43 \\
\hline & & $15+$ & 1.46 & .686 & 92 \\
\hline & & Total & 1.41 & .714 & 227 \\
\hline
\end{tabular}




\section{Levene's Test of Equality of Error Variancess}

Dependent Variable: CURRENT USE

\begin{tabular}{|l|r|r|r|}
\hline$F$ & df1 & df2 & Sig. \\
\hline 5.160 & 15 & 211 & .000 \\
\hline
\end{tabular}

Tests the null hypothesis that the error variance of the dependt variable is equal across groups.

a. Design: Intercept+Sex+Afield+Experien+Sex *Afield+Se:

${ }^{*}$ Experien+Afield * Experien+Sex * Afield * Experien

\section{Tests of Between-Subjects Effects}

Dependent Variable: CURRENT USE

\begin{tabular}{|l|r|r|r|r|r|r|}
\hline Source & $\begin{array}{c}\text { Type III Sum } \\
\text { of Squares }\end{array}$ & df & Mean Square & \multicolumn{1}{c|}{ F } & Sig. & $\begin{array}{c}\text { Partial Eta } \\
\text { Squared }\end{array}$ \\
\hline Corrected Model & $22.024^{a}$ & 15 & 1.468 & 3.329 & .000 & .191 \\
Intercept & 364.392 & 1 & 364.392 & 826.285 & .000 & .797 \\
Sex & 9.964 & 1 & 9.964 & 22.594 & .000 & .097 \\
Afield & .060 & 1 & .060 & .137 & .712 & .001 \\
Experien & 2.738 & 3 & .913 & 2.069 & .105 & .029 \\
Sex * Afield & 5.646 & 1 & 5.646 & 12.802 & .000 & .057 \\
Sex * Experien & 3.098 & 3 & 1.033 & 2.342 & .074 & .032 \\
Afield * Experien & 4.821 & 3 & 1.607 & 3.644 & .014 & .049 \\
Sex* Afield * Experien & 3.444 & 3 & 1.148 & 2.603 & .053 & .036 \\
Error & 93.051 & 211 & .441 & & & \\
Total & 569.000 & 227 & & & & \\
Corrected Total & 115.075 & 226 & & & & \\
\hline
\end{tabular}

a. R Squared $=.191$ (Adjusted R Squared $=.134)$

\section{Estimated Marginal Means}

\section{Grand Mean}

Dependent Variable: CURRENT USE

\begin{tabular}{|c|r|r|r|}
\hline \multirow{2}{*}{ Mean } & \multirow{2}{*}{ Std. Error } & \multicolumn{2}{|c|}{$95 \%$ Confidence Interval } \\
\cline { 3 - 4 } & .050 & Lower Bound & Upper Bound \\
\hline 1.444 & .345 & 1.543 \\
\hline
\end{tabular}

\section{Sex}




\section{Estimates}

Dependent Variable: CURRENT USE

\begin{tabular}{|l|r|r|r|r|}
\hline & & & \multicolumn{2}{|c|}{$95 \%$ Confidence Interval } \\
\cline { 4 - 5 } Sex & Mean & Std. Error & Lower Bound & Upper Bound \\
\hline male & 1.683 & .078 & 1.530 & 1.837 \\
female & 1.206 & .063 & 1.080 & 1.331 \\
\hline
\end{tabular}

\section{Pairwise Comparisons}

Dependent Variable: CURRENT USE

\begin{tabular}{|c|c|c|c|c|c|c|}
\hline \multirow[b]{2}{*}{ (I) Sex } & \multirow[b]{2}{*}{ (J) Sex } & \multirow{2}{*}{$\begin{array}{c}\text { Mean } \\
\text { Difference (I-J) }\end{array}$} & \multirow[b]{2}{*}{ Std. Error } & \multirow[b]{2}{*}{ Sig. ${ }^{a}$} & \multicolumn{2}{|c|}{$\begin{array}{c}\text { 95\% Confidence Interval for } \\
\text { Difference }\end{array}$} \\
\hline & & & & & Lower Bound & Upper Bound \\
\hline male & female & $.478^{*}$ & .100 & .000 & .280 & .676 \\
\hline female & male & $-.478^{*}$ & .100 & .000 & -.676 & -.280 \\
\hline
\end{tabular}

Based on estimated marginal means

*. The mean difference is significant at the .05 level.

a. Adjustment for multiple comparisons: Least Significant Difference (equivalent to no adjustments).

\section{Univariate Tests}

Dependent Variable: CURRENT USE

\begin{tabular}{|l|r|r|r|r|r|r|}
\hline & $\begin{array}{c}\text { Sum of } \\
\text { Squares }\end{array}$ & df & Mean Square & F & Sig. & $\begin{array}{c}\text { Partial Eta } \\
\text { Squared }\end{array}$ \\
\hline Contrast & 9.964 & 1 & 9.964 & 22.594 & .000 & .097 \\
Error & 93.051 & 211 & .441 & & & \\
\hline
\end{tabular}

The $\mathrm{F}$ tests the effect of Sex. This test is based on the linearly independent pairwise compi among the estimated marginal means.

\section{Academic field}

\section{Estimates}

Dependent Variable: CURRENT USE

\begin{tabular}{|l|r|r|r|r|}
\hline & & & \multicolumn{2}{|c|}{$95 \%$ Confidence Interval } \\
\cline { 4 - 5 } Academic field & Mean & Std. Error & Lower Bound & Upper Bound \\
\hline Scientific & 1.463 & .067 & 1.331 & 1.595 \\
Humanities & 1.426 & .075 & 1.278 & 1.574 \\
\hline
\end{tabular}


Pairwise Comparisons

Dependent Variable: CURRENT USE

\begin{tabular}{|c|c|c|c|c|c|c|}
\hline \multirow[b]{2}{*}{ (I) Academic field } & \multirow[b]{2}{*}{ (J) Academic field } & \multirow{2}{*}{$\begin{array}{c}\text { Mean } \\
\text { Difference (I-J) }\end{array}$} & \multirow[b]{2}{*}{ Std. Error } & \multirow[b]{2}{*}{ Sig. ${ }^{a}$} & \multicolumn{2}{|c|}{$\begin{array}{c}\text { 95\% Confidence Interval for } \\
\text { Difference } \\
\text { Da }\end{array}$} \\
\hline & & & & & Lower Bound & Upper Bound \\
\hline scientific & Humanities & .037 & .100 & .712 & -.161 & .235 \\
\hline Humanities & scientific & -.037 & .100 & .712 & -.235 & .161 \\
\hline
\end{tabular}

Based on estimated marginal means

a. Adjustment for multiple comparisons: Least Significant Difference (equivalent to no adjustments).

\section{Univariate Tests}

Dependent Variable: CURRENT USE

\begin{tabular}{|l|r|r|r|r|r|r|}
\hline & $\begin{array}{c}\text { Sum of } \\
\text { Squares }\end{array}$ & df & Mean Square & F & Sig. & $\begin{array}{c}\text { Partial Eta } \\
\text { Squared }\end{array}$ \\
\hline Contrast & .060 & 1 & .060 & .137 & .712 & .001 \\
Error & 93.051 & 211 & .441 & & & \\
\hline
\end{tabular}

The $\mathrm{F}$ tests the effect of Academic field. This test is based on the linearly independent pair comparisons among the estimated marginal means.

\section{Experience}

\section{Estimates}

Dependent Variable: CURRENT USE

\begin{tabular}{|l|r|r|r|r|}
\hline & & & \multicolumn{2}{|c|}{$95 \%$ Confidence Interval } \\
\cline { 4 - 5 } Experience & Mean & Std. Error & Lower Bound & Upper Bound \\
\hline $0-5$ & 1.257 & .103 & 1.054 & 1.459 \\
$6-10$ & 1.475 & .111 & 1.257 & 1.693 \\
$11-15$ & 1.627 & .111 & 1.409 & 1.845 \\
$15+$ & 1.419 & .073 & 1.274 & 1.564 \\
\hline
\end{tabular}


Pairwise Comparisons

Dependent Variable: CURRENT USE

\begin{tabular}{|c|c|c|c|c|c|c|}
\hline & & Mean & & & $\begin{array}{r}\text { 95\% Confiden } \\
\text { Diffe }\end{array}$ & $\begin{array}{l}\text { ce Interval for } \\
\text { ence } \\
\text { ence }\end{array}$ \\
\hline (I) Experience & (J) Experience & Difference (I-J) & Std. Error & Sig. ${ }^{a}$ & Lower Bound & Upper Bound \\
\hline $0-5$ & $6-10$ & -.218 & .151 & .149 & -.516 & .079 \\
\hline & $11-15$ & $-.370^{*}$ & 151 & .015 & -.668 & -.073 \\
\hline & $15+$ & -.162 & .126 & .200 & -.411 & .086 \\
\hline $6-10$ & $0-5$ & .218 & .151 & .149 & -.079 & .516 \\
\hline & $11-15$ & -.152 & 156 & .333 & -.460 & 157 \\
\hline & $15+$ & .056 & 133 & .672 & -.206 & .318 \\
\hline $11-15$ & $0-5$ & $.370^{*}$ & .151 & .015 & .073 & .668 \\
\hline & $6-10$ & .152 & 156 & .333 & -.157 & .460 \\
\hline & $15+$ & .208 & .133 & .119 & -.054 & .470 \\
\hline $15+$ & $0-5$ & .162 & .126 & .200 & -.086 & .411 \\
\hline & $6-10$ & -.056 & .133 & .672 & -.318 & .206 \\
\hline & $11-15$ & -.208 & .133 & .119 & -.470 & .054 \\
\hline
\end{tabular}

Based on estimated marginal means

*. The mean difference is significant at the .05 level.

a. Adjustment for multiple comparisons: Least Significant Difference (equivalent to no adjustments).

\section{Univariate Tests}

Dependent Variable: CURRENT USE

\begin{tabular}{|l|r|r|r|r|r|r|}
\hline & $\begin{array}{c}\text { Sum of } \\
\text { Squares }\end{array}$ & \multicolumn{1}{c|}{$\mathrm{df}$} & Mean Square & $\mathrm{F}$ & \multicolumn{1}{c|}{ Sig. } & $\begin{array}{c}\text { Partial Eta } \\
\text { Squared }\end{array}$ \\
\hline Contrast & 2.738 & 3 & .913 & 2.069 & .105 & .029 \\
Error & 93.051 & 211 & .441 & & & \\
\hline
\end{tabular}

The $\mathrm{F}$ tests the effect of Experience. This test is based on the linearly independent pairwisı comparisons among the estimated marginal means.

\section{Sex * Academic field}

Dependent Variable: CURRENT USE

\begin{tabular}{|ll|r|r|r|r|}
\hline & & & & \multicolumn{2}{|c|}{$95 \%$ Confidence Interval } \\
\cline { 5 - 6 } Sex & Academic field & Mean & Std. Error & Lower Bound & Upper Bound \\
\hline male & scientific & 1.522 & .104 & 1.316 & 1.728 \\
& Humanities & 1.845 & .116 & 1.616 & 2.073 \\
\hline female & scientific & 1.404 & .084 & 1.239 & 1.569 \\
& Humanities & 1.007 & .096 & .819 & 1.196 \\
\hline
\end{tabular}




\section{Sex * Experience}

Dependent Variable: CURRENT USE

\begin{tabular}{|ll|r|r|r|r|}
\hline & & & \multicolumn{2}{|c|}{$95 \%$ Confidence Interval } \\
\cline { 5 - 6 } Sex & Experience & Mean & Std. Error & Lower Bound & Upper Bound \\
\hline male & $0-5$ & 1.437 & .149 & 1.143 & 1.731 \\
& $6-10$ & 1.646 & .175 & 1.302 & 1.991 \\
& $11-15$ & 2.100 & .182 & 1.741 & 2.459 \\
& $15+$ & 1.550 & .106 & 1.341 & 1.759 \\
\hline female & $0-5$ & 1.076 & .141 & .798 & 1.355 \\
& $6-10$ & 1.304 & .136 & 1.036 & 1.572 \\
& $11-15$ & 1.154 & .126 & .906 & 1.402 \\
$15+$ & 1.288 & .101 & 1.088 & 1.487 \\
\hline
\end{tabular}

\section{Academic field * Experience}

Dependent Variable: CURRENT USE

\begin{tabular}{|ll|r|r|r|r|}
\hline \multirow{2}{*}{ Academic field } & Experience & Mean & Std. Error & \multicolumn{2}{|c|}{ 95\% Confidence Interval } \\
\cline { 5 - 6 } & $0-5$ & 1.433 & .112 & 1.212 & 1.654 \\
& $6-10$ & 1.527 & .179 & 1.174 & 1.880 \\
& $11-15$ & 1.354 & .140 & 1.079 & 1.629 \\
& $15+$ & 1.538 & .085 & 1.370 & 1.706 \\
\hline Humanities & $0-5$ & 1.080 & .172 & .742 & 1.419 \\
& $6-10$ & 1.423 & .130 & 1.166 & 1.680 \\
& $11-15$ & 1.900 & .171 & 1.562 & 2.238 \\
& $15+$ & 1.300 & .119 & 1.065 & 1.535 \\
\hline
\end{tabular}




\section{Sex * Academic field * Experience}

Dependent Variable: CURRENT USE

\begin{tabular}{|c|c|c|c|c|c|c|}
\hline \multirow{2}{*}{ Sex } & \multirow[b]{2}{*}{ Academic field } & \multirow[b]{2}{*}{ Experience } & \multirow[b]{2}{*}{ Mean } & \multirow[b]{2}{*}{ Std. Error } & \multicolumn{2}{|c|}{ 95\% Confidence Interval } \\
\hline & & & & & Lower Bound & Upper Bound \\
\hline \multirow[t]{8}{*}{ male } & scientific & $0-5$ & 1.588 & .161 & 1.271 & 1.906 \\
\hline & & $6-10$ & 1.600 & .297 & 1.015 & 2.185 \\
\hline & & $11-15$ & 1.400 & .210 & .986 & 1.814 \\
\hline & & $15+$ & 1.500 & .125 & 1.253 & 1.747 \\
\hline & Humanities & $0-5$ & 1.286 & .251 & .791 & 1.780 \\
\hline & & $6-10$ & 1.692 & .184 & 1.329 & 2.055 \\
\hline & & $11-15$ & 2.800 & 297 & 2.215 & 3.385 \\
\hline & & $15+$ & 1.600 & 171 & 1.262 & 1.938 \\
\hline \multirow[t]{8}{*}{ female } & scientific & $0-5$ & 1.278 & .157 & .969 & 1.586 \\
\hline & & $6-10$ & 1.455 & 200 & 1.060 & 1.849 \\
\hline & & $11-15$ & 1.308 & .184 & .945 & 1.671 \\
\hline & & $15+$ & 1.576 & 116 & 1.348 & 1.804 \\
\hline & Humanities & $0-5$ & .875 & .235 & .412 & 1.338 \\
\hline & & $6-10$ & 1.154 & 184 & .791 & 1.517 \\
\hline & & $11-15$ & 1.000 & .171 & .662 & 1.338 \\
\hline & & $15+$ & 1.000 & 166 & .673 & 1.327 \\
\hline
\end{tabular}

\section{Post Hoc Tests}

\section{Experience}

\section{Multiple Comparisons}

Dependent Variable: CURRENT USE

Scheffe

\begin{tabular}{|c|c|c|c|c|c|c|}
\hline \multirow[b]{2}{*}{ (I) Experience } & \multirow[b]{2}{*}{ (J) Experience } & \multirow{2}{*}{$\begin{array}{c}\text { Mean } \\
\text { Difference (I-J) }\end{array}$} & \multirow[b]{2}{*}{ Std. Error } & \multirow[b]{2}{*}{ Sig. } & \multicolumn{2}{|c|}{ 95\% Confidence Interval } \\
\hline & & & & & Lower Bound & Upper Bound \\
\hline \multirow[t]{3}{*}{$0-5$} & $6-10$ & -.13 & .139 & .824 & -.52 & .26 \\
\hline & $11-15$ & -.08 & 138 & .960 & -.46 & .31 \\
\hline & $15+$ & -.14 & .117 & .713 & -.47 & .19 \\
\hline \multirow[t]{3}{*}{$6-10$} & $0-5$ & .13 & .139 & .824 & -.26 & .52 \\
\hline & $11-15$ & .06 & .144 & .984 & -.35 & .46 \\
\hline & $15+$ & .00 & .124 & 1.000 & -.35 & .34 \\
\hline \multirow[t]{3}{*}{$11-15$} & $0-5$ & .08 & 138 & .960 & -.31 & .46 \\
\hline & $6-10$ & -.06 & .144 & .984 & -.46 & .35 \\
\hline & $15+$ & -.06 & .123 & .969 & -.41 & .28 \\
\hline \multirow[t]{3}{*}{$15+$} & $0-5$ & .14 & .117 & .713 & -.19 & .47 \\
\hline & $6-10$ & .00 & .124 & 1.000 & -.34 & .35 \\
\hline & $11-15$ & .06 & .123 & .969 & -.28 & .41 \\
\hline
\end{tabular}

Based on observed means. 


\section{Homogeneous Subsets}

CURRENT USE
\begin{tabular}{|l|r|c|}
\hline Scheffe ${ }^{\text {a,b,c }}$ & \\
\hline & & Subset \\
\cline { 3 - 3 } Experience & $\mathrm{N}$ & 1 \\
\hline $0-5$ & 50 & 1.32 \\
$11-15$ & 43 & 1.40 \\
$6-10$ & 42 & 1.45 \\
$15+$ & 92 & 1.46 \\
Sig. & & .781 \\
\hline
\end{tabular}

Means for groups in homogeneous subsets are displayed.

Based on Type III Sum of Squares

The error term is Mean Square(Error) $=.441$.

a. Uses Harmonic Mean Sample Size $=51.325$.

b. The group sizes are unequal. The harmonic mean of the group sizes is used. Type I error levels are not guaranteed.

c. Alpha $=.05$.

\section{Profile Plots}




\section{Estimated Marginal Means of CURRENT USE}

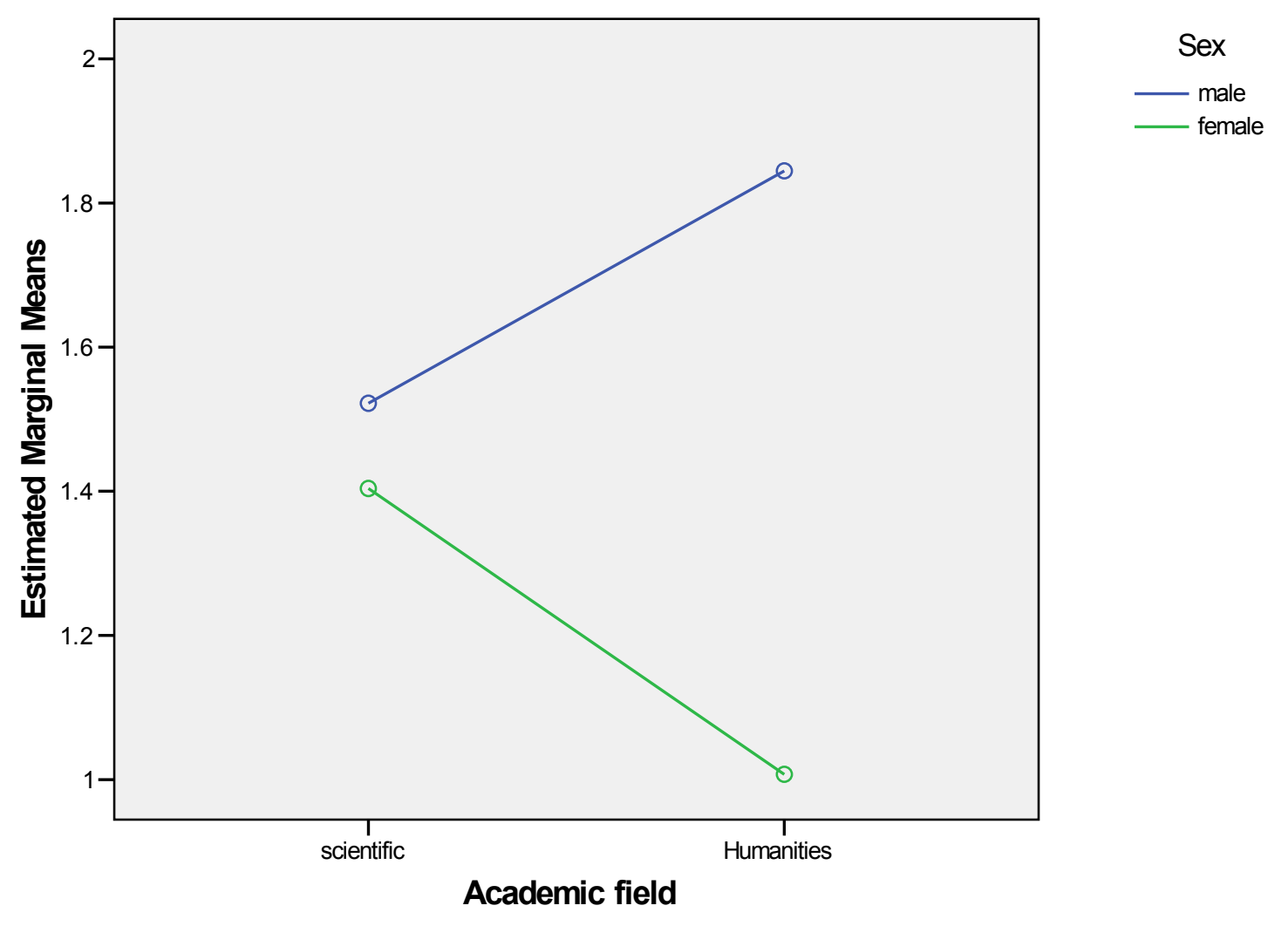




\section{Estimated Marginal Means of CURRENT USE}

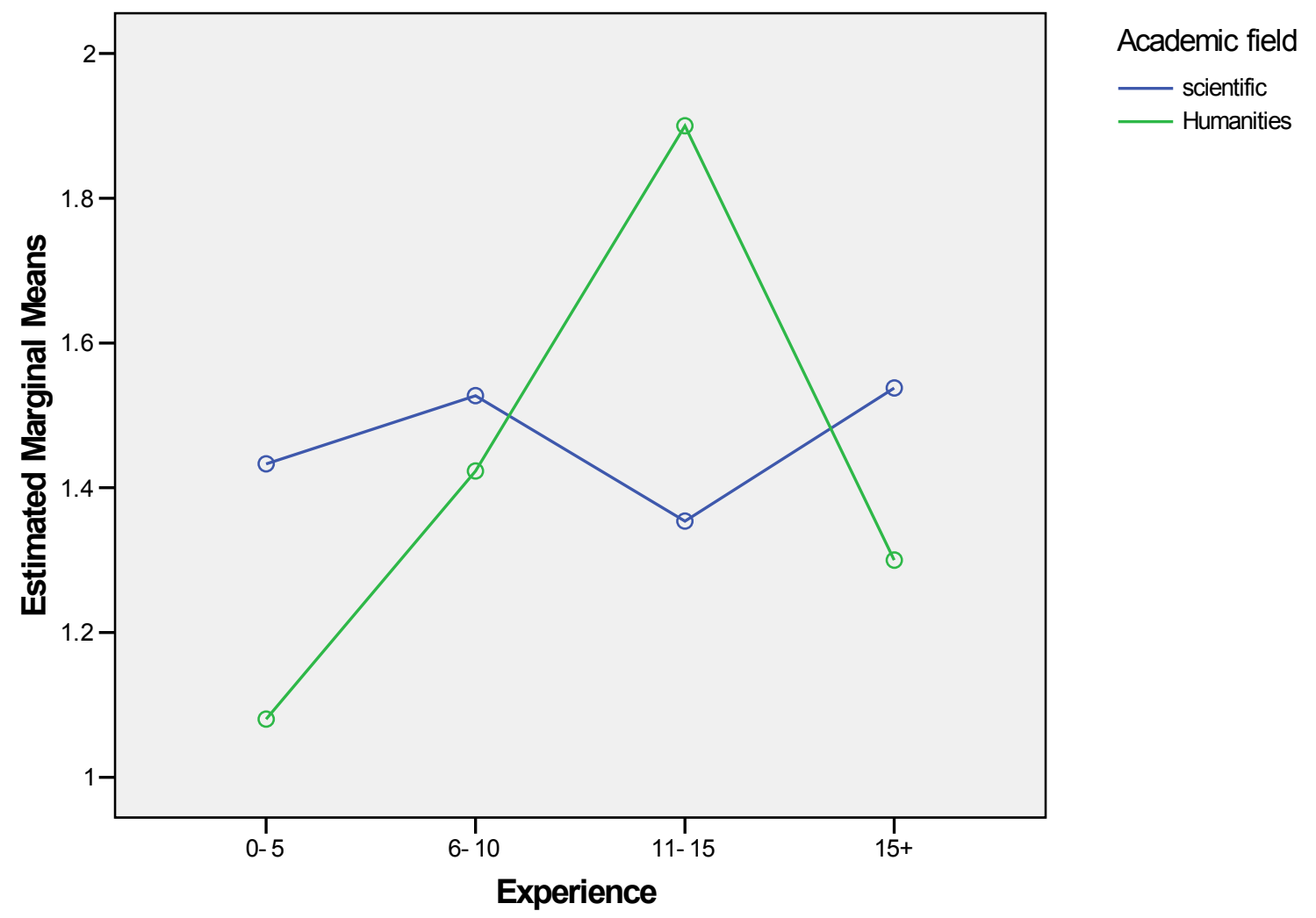

Appendix J: 3-way Factorial ANOVA for Motivations

\section{Univariate Analysis of Variance}


Between-Subjects Factors

\begin{tabular}{|ll|l|r|}
\hline & & Value Label & $\mathrm{N}$ \\
\hline Sex & 1 & male & 100 \\
& 2 & female & 127 \\
Academic & 1 & scientific & 135 \\
field & 2 & Humanities & 92 \\
Experience & 0 & $0-5$ & 50 \\
& 1 & $6-10$ & 42 \\
& 2 & $11-15$ & 43 \\
& 3 & $15+$ & 92 \\
\hline
\end{tabular}


Descriptive Statistics

Dependent Variable: MOTIVATION

\begin{tabular}{|c|c|c|c|c|c|}
\hline Sex & Academic field & Experience & Mean & Std. Deviation & $\mathrm{N}$ \\
\hline \multirow[t]{15}{*}{ male } & \multirow[t]{5}{*}{ scientific } & $0-5$ & 2.47 & .943 & 17 \\
\hline & & $6-10$ & 2.80 & .447 & 5 \\
\hline & & $11-15$ & 2.70 & .949 & 10 \\
\hline & & $15+$ & 3.11 & .685 & 28 \\
\hline & & Total & 2.83 & .827 & 60 \\
\hline & \multirow[t]{5}{*}{ Humanities } & $0-5$ & 3.14 & .690 & 7 \\
\hline & & $6-10$ & 3.15 & .801 & 13 \\
\hline & & $11-15$ & 3.00 & 1.000 & 5 \\
\hline & & $15+$ & 3.07 & .799 & 15 \\
\hline & & Total & 3.10 & .778 & 40 \\
\hline & \multirow[t]{5}{*}{ Total } & $0-5$ & 2.67 & .917 & 24 \\
\hline & & $6-10$ & 3.06 & .725 & 18 \\
\hline & & $11-15$ & 2.80 & .941 & 15 \\
\hline & & $15+$ & 3.09 & .718 & 43 \\
\hline & & Total & 2.94 & .814 & 100 \\
\hline \multirow[t]{15}{*}{ female } & \multirow[t]{5}{*}{ scientific } & $0-5$ & 3.06 & .998 & 18 \\
\hline & & $6-10$ & 3.27 & .905 & 11 \\
\hline & & $11-15$ & 2.85 & .801 & 13 \\
\hline & & $15+$ & 3.00 & .791 & 33 \\
\hline & & Total & 3.03 & .854 & 75 \\
\hline & \multirow[t]{5}{*}{ Humanities } & $0-5$ & 3.38 & 1.061 & 8 \\
\hline & & $6-10$ & 3.23 & .832 & 13 \\
\hline & & $11-15$ & 2.93 & 1.280 & 15 \\
\hline & & $15+$ & 2.81 & 1.276 & 16 \\
\hline & & Total & 3.04 & 1.137 & 52 \\
\hline & \multirow[t]{5}{*}{ Total } & $0-5$ & 3.15 & 1.008 & 26 \\
\hline & & $6-10$ & 3.25 & .847 & 24 \\
\hline & & $11-15$ & 2.89 & 1.066 & 28 \\
\hline & & $15+$ & 2.94 & .966 & 49 \\
\hline & & Total & 3.03 & .975 & 127 \\
\hline \multirow[t]{15}{*}{ Total } & \multirow[t]{5}{*}{ scientific } & $0-5$ & 2.77 & 1.003 & 35 \\
\hline & & $6-10$ & 3.13 & .806 & 16 \\
\hline & & $11-15$ & 2.78 & .850 & 23 \\
\hline & & $15+$ & 3.05 & .740 & 61 \\
\hline & & Total & 2.94 & .844 & 135 \\
\hline & \multirow[t]{5}{*}{ Humanities } & $0-5$ & 3.27 & .884 & 15 \\
\hline & & $6-10$ & 3.19 & .801 & 26 \\
\hline & & $11-15$ & 2.95 & 1.191 & 20 \\
\hline & & $15+$ & 2.94 & 1.063 & 31 \\
\hline & & Total & 3.07 & .992 & 92 \\
\hline & \multirow[t]{5}{*}{ Total } & $0-5$ & 2.92 & .986 & 50 \\
\hline & & $6-10$ & 3.17 & .794 & 42 \\
\hline & & $11-15$ & 2.86 & 1.014 & 43 \\
\hline & & $15+$ & 3.01 & .858 & 92 \\
\hline & & Total & 2.99 & .907 & 227 \\
\hline
\end{tabular}




\section{Levene's Test of Equality of Error Variancess}

Dependent Variable: MOTIVATION

\begin{tabular}{|l|l|l|l|}
\hline$F$ & df1 & df2 & Sig. \\
\hline 1.196 & 15 & 211 & .276 \\
\hline
\end{tabular}

Tests the null hypothesis that the error variance of the dependt variable is equal across groups.

a. Design: Intercept+Sex+Afield+Experien+Sex *Afield+Se:

${ }^{*}$ Experien+Afield * Experien+Sex * Afield * Experien

Tests of Between-Subjects Effects

Dependent Variable: MOTIVATION

\begin{tabular}{|l|r|r|r|r|r|r|}
\hline Source & $\begin{array}{c}\text { Type III Sum } \\
\text { of Squares }\end{array}$ & df & Mean Square & \multicolumn{1}{c|}{ F } & \multicolumn{1}{c|}{ Sig. } & $\begin{array}{c}\text { Partial Eta } \\
\text { Squared }\end{array}$ \\
\hline Corrected Model & $10.314^{\mathrm{a}}$ & 15 & .688 & .826 & .648 & .055 \\
Intercept & 1569.724 & 1 & 1569.724 & 1885.433 & .000 & .899 \\
Sex & .803 & 1 & .803 & .965 & .327 & .005 \\
Afield & 1.460 & 1 & 1.460 & 1.753 & .187 & .008 \\
Experien & 1.086 & 3 & .362 & .435 & .728 & .006 \\
Sex *Afield & .838 & 1 & .838 & 1.007 & .317 & .005 \\
Sex * Experien & 2.873 & 3 & .958 & 1.150 & .330 & .016 \\
Afield * Experien & 2.660 & 3 & .887 & 1.065 & .365 & .015 \\
Sex *Afield * Experien & .133 & 3 & .044 & .053 & .984 & .001 \\
Error & 175.669 & 211 & .833 & & & \\
Total & 2217.000 & 227 & & & & \\
Corrected Total & 185.982 & 226 & & & & \\
\hline
\end{tabular}

a. $\mathrm{R}$ Squared $=.055$ (Adjusted R Squared $=-.012$ )

\section{Estimated Marginal Means}

\section{Grand Mean}

Dependent Variable: MOTIVATION

\begin{tabular}{|c|r|r|r|}
\hline & & \multicolumn{2}{|c|}{$95 \%$ Confidence Interval } \\
\cline { 3 - 4 } Mean & Std. Error & Lower Bound & Upper Bound \\
\hline 2.998 & .069 & 2.862 & 3.134 \\
\hline
\end{tabular}




\section{Sex}

\section{Estimates}

Dependent Variable: MOTIVATION

\begin{tabular}{|l|c|r|r|r|}
\hline & & & \multicolumn{2}{|c|}{$95 \%$ Confidence Interval } \\
\cline { 4 - 5 } Sex & Mean & Std. Error & Lower Bound & Upper Bound \\
\hline male & 2.930 & .107 & 2.719 & 3.141 \\
female & 3.066 & .087 & 2.894 & 3.238 \\
\hline
\end{tabular}

\section{Pairwise Comparisons}

Dependent Variable: MOTIVATION

\begin{tabular}{|c|c|c|c|c|c|c|}
\hline \multirow[b]{2}{*}{ (I) Sex } & \multirow[b]{2}{*}{ (J) Sex } & \multirow{2}{*}{$\begin{array}{c}\text { Mean } \\
\text { Difference (I-J) }\end{array}$} & \multirow[b]{2}{*}{ Std. Error } & \multirow[b]{2}{*}{ Sig. ${ }^{a}$} & \multicolumn{2}{|c|}{$\begin{array}{c}95 \% \text { Confidence Interval for } \\
\text { Difference }\end{array}$} \\
\hline & & & & & Lower Bound & Upper Bound \\
\hline male & female & -.136 & .138 & .327 & -.408 & .137 \\
\hline female & male & .136 & .138 & .327 & -.137 & .408 \\
\hline
\end{tabular}

Based on estimated marginal means

a. Adjustment for multiple comparisons: Least Significant Difference (equivalent to no adjustments).

\section{Univariate Tests}

Dependent Variable: MOTIVATION

\begin{tabular}{|l|r|r|r|r|r|r|}
\hline & $\begin{array}{c}\text { Sum of } \\
\text { Squares }\end{array}$ & \multicolumn{1}{c|}{$\mathrm{df}$} & Mean Square & $\mathrm{F}$ & \multicolumn{1}{c|}{ Sig. } & $\begin{array}{c}\text { Partial Eta } \\
\text { Squared }\end{array}$ \\
\hline Contrast & .803 & 1 & .803 & .965 & .327 & .005 \\
Error & 175.669 & 211 & .833 & & & \\
\hline
\end{tabular}

The $F$ tests the effect of Sex. This test is based on the linearly independent pairwise compi among the estimated marginal means.

\section{Academic field}

\section{Estimates}

Dependent Variable: MOTIVATION

\begin{tabular}{|l|r|r|r|r|}
\hline & & & \multicolumn{2}{|c|}{$95 \%$ Confidence Interval } \\
\cline { 4 - 5 } Academic field & Mean & Std. Error & Lower Bound & Upper Bound \\
\hline Scientific & 2.907 & .092 & 2.726 & 3.088 \\
Humanities & 3.089 & .103 & 2.886 & 3.293 \\
\hline
\end{tabular}


Pairwise Comparisons

Dependent Variable: MOTIVATION

\begin{tabular}{|c|c|c|c|c|c|c|}
\hline \multirow[b]{2}{*}{ (I) Academic field } & \multirow[b]{2}{*}{ (J) Academic field } & \multirow{2}{*}{$\begin{array}{c}\text { Mean } \\
\text { Difference (I-J) }\end{array}$} & \multirow[b]{2}{*}{ Std. Error } & \multirow[b]{2}{*}{ Sig. ${ }^{a}$} & \multicolumn{2}{|c|}{$\begin{array}{c}\text { 95\% Confidence Interval for } \\
\text { Difference }^{\mathrm{a}}\end{array}$} \\
\hline & & & & & Lower Bound & Upper Bound \\
\hline scientific & Humanities & -.183 & .138 & .187 & -.455 & .089 \\
\hline Humanities & scientific & .183 & .138 & .187 & -.089 & .455 \\
\hline
\end{tabular}

Based on estimated marginal means

a. Adjustment for multiple comparisons: Least Significant Difference (equivalent to no adjustments).

\section{Univariate Tests}

Dependent Variable: MOTIVATION

\begin{tabular}{|l|r|r|r|r|r|r|}
\hline & $\begin{array}{c}\text { Sum of } \\
\text { Squares }\end{array}$ & \multicolumn{1}{c|}{$\mathrm{df}$} & Mean Square & $\mathrm{F}$ & \multicolumn{1}{c|}{ Sig. } & $\begin{array}{c}\text { Partial Eta } \\
\text { Squared }\end{array}$ \\
\hline Contrast & 1.460 & 1 & 1.460 & 1.753 & .187 & .008 \\
Error & 175.669 & 211 & .833 & & & \\
\hline
\end{tabular}

The $F$ tests the effect of Academic field. This test is based on the linearly independent pair comparisons among the estimated marginal means.

\section{Experience}

\section{Estimates}

Dependent Variable: MOTIVATION

\begin{tabular}{|l|r|r|r|r|}
\hline & & & \multicolumn{2}{|c|}{ 95\% Confidence Interval } \\
\cline { 4 - 5 } Experience & Mean & Std. Error & Lower Bound & Upper Bound \\
\hline $0-5$ & 3.011 & .141 & 2.733 & 3.289 \\
$6-10$ & 3.114 & .152 & 2.814 & 3.414 \\
$11-15$ & 2.870 & .152 & 2.570 & 3.169 \\
$15+$ & 2.997 & .101 & 2.798 & 3.195 \\
\hline
\end{tabular}


Pairwise Comparisons

Dependent Variable: MOTIVATION

\begin{tabular}{|c|c|c|c|c|c|c|}
\hline & & Mean & & & $\begin{array}{r}\text { 95\% Confider } \\
\text { Diffe }\end{array}$ & $\begin{array}{l}\text { ce Interval for } \\
\text { ence }\end{array}$ \\
\hline (I) Experience & (J) Experience & Difference (I-J) & Std. Error & Sig. ${ }^{a}$ & Lower Bound & Upper Bound \\
\hline $0-5$ & $6-10$ & -.103 & .207 & .619 & -.512 & .306 \\
\hline & $11-15$ & .141 & .207 & .497 & -.268 & .550 \\
\hline & $15+$ & .014 & .173 & .934 & -.327 & .356 \\
\hline $6-10$ & $0-5$ & .103 & .207 & .619 & -.306 & .512 \\
\hline & $11-15$ & 244 & .215 & .257 & -.179 & .668 \\
\hline & $15+$ & .118 & .182 & .519 & -.242 & .477 \\
\hline $11-15$ & $0-5$ & -.141 & .207 & .497 & -.550 & .268 \\
\hline & $6-10$ & -.244 & .215 & .257 & -.668 & .179 \\
\hline & $15+$ & -.127 & .182 & .488 & -.486 & .233 \\
\hline $15+$ & $0-5$ & -.014 & .173 & .934 & -.356 & .327 \\
\hline & $6-10$ & -.118 & .182 & .519 & -.477 & .242 \\
\hline & $11-15$ & .127 & .182 & .488 & -.233 & .486 \\
\hline
\end{tabular}

Based on estimated marginal means

a. Adjustment for multiple comparisons: Least Significant Difference (equivalent to no adjustments).

\section{Univariate Tests}

Dependent Variable: MOTIVATION

\begin{tabular}{|l|r|r|r|r|r|r|}
\hline & $\begin{array}{c}\text { Sum of } \\
\text { Squares }\end{array}$ & \multicolumn{1}{c|}{$\mathrm{df}$} & Mean Square & $\mathrm{F}$ & \multicolumn{1}{c|}{ Sig. } & $\begin{array}{c}\text { Partial Eta } \\
\text { Squared }\end{array}$ \\
\hline Contrast & 1.086 & 3 & .362 & .435 & .728 & .006 \\
Error & 175.669 & 211 & .833 & & & \\
\hline
\end{tabular}

The $\mathrm{F}$ tests the effect of Experience. This test is based on the linearly independent pairwis comparisons among the estimated marginal means.

\section{Sex * Academic field}

Dependent Variable: MOTIVATION

\begin{tabular}{|ll|r|r|r|r|}
\hline & & & \multicolumn{2}{|c|}{$95 \%$ Confidence Interval } \\
\cline { 5 - 6 } Sex & Academic field & Mean & Std. Error & Lower Bound & Upper Bound \\
\hline male & scientific & 2.769 & .143 & 2.487 & 3.052 \\
& Humanities & 3.091 & .159 & 2.777 & 3.404 \\
\hline \multirow{2}{*}{ female } & scientific & 3.044 & .115 & 2.817 & 3.270 \\
& Humanities & 3.088 & .131 & 2.829 & 3.347 \\
\hline
\end{tabular}




\section{Sex * Experience}

Dependent Variable: MOTIVATION

\begin{tabular}{|ll|r|r|r|r|}
\hline & & & \multicolumn{2}{|c|}{$95 \%$ Confidence Interval } \\
\cline { 5 - 6 } Sex & Experience & Mean & Std. Error & Lower Bound & Upper Bound \\
\hline male & $0-5$ & 2.807 & .205 & 2.403 & 3.211 \\
& $6-10$ & 2.977 & .240 & 2.504 & 3.450 \\
& $11-15$ & 2.850 & .250 & 2.357 & 3.343 \\
& $15+$ & 3.087 & .146 & 2.799 & 3.375 \\
\hline female & $0-5$ & 3.215 & .194 & 2.833 & 3.597 \\
& $6-10$ & 3.252 & .187 & 2.883 & 3.620 \\
& $11-15$ & 2.890 & .173 & 2.549 & 3.231 \\
$15+$ & 2.906 & .139 & 2.632 & 3.180 \\
\hline
\end{tabular}

\section{Academic field * Experience}

Dependent Variable: MOTIVATION

\begin{tabular}{|ll|r|r|r|r|}
\hline & & & \multicolumn{2}{|c|}{ 95\% Confidence Interval } \\
\cline { 5 - 6 } Academic field & Experience & Mean & Std. Error & Lower Bound & Upper Bound \\
\hline scientific & $0-5$ & 2.763 & .154 & 2.459 & 3.067 \\
& $6-10$ & 3.036 & .246 & 2.551 & 3.521 \\
& $11-15$ & 2.773 & .192 & 2.395 & 3.151 \\
& $15+$ & 3.054 & .117 & 2.822 & 3.285 \\
\hline Humanities & $0-5$ & 3.259 & .236 & 2.793 & 3.724 \\
& $6-10$ & 3.192 & .179 & 2.840 & 3.545 \\
& $11-15$ & 2.967 & .236 & 2.502 & 3.431 \\
& $15+$ & 2.940 & .164 & 2.616 & 3.263 \\
\hline
\end{tabular}




\section{Sex * Academic field * Experience}

Dependent Variable: MOTIVATION

\begin{tabular}{|lll|r|r|r|r|}
\hline & & & & \multicolumn{2}{|c|}{$95 \%$ Confidence Interval } \\
\cline { 5 - 7 } Sex & Academic field & Experience & Mean & Std. Error & Lower Bound & Upper Bound \\
\hline male & scientific & $0-5$ & 2.471 & .221 & 2.034 & 2.907 \\
& & $6-10$ & 2.800 & .408 & 1.996 & 3.604 \\
& $11-15$ & 2.700 & .289 & 2.131 & 3.269 \\
& & 3.107 & .172 & 2.767 & 3.447 \\
\cline { 5 - 7 } & & & & & & \\
& Humanities & $0-5$ & 3.143 & .345 & 2.463 & 3.823 \\
& $6-10$ & 3.154 & .253 & 2.655 & 3.653 \\
& $11-15$ & 3.000 & .408 & 2.196 & 3.804 \\
& $15+$ & 3.067 & .236 & 2.602 & 3.531 \\
\hline female & scientific & $0-5$ & 3.056 & .215 & 2.632 & 3.480 \\
& $6-10$ & 3.273 & .275 & 2.730 & 3.815 \\
& $11-15$ & 2.846 & .253 & 2.347 & 3.345 \\
& $15+$ & 3.000 & .159 & 2.687 & 3.313 \\
\hline & & 3.375 & .323 & 2.739 & 4.011 \\
& Humanities & $0-5$ & 3.231 & .253 & 2.732 & 3.730 \\
& $6-10$ & 2.933 & .236 & 2.469 & 3.398 \\
& $11-15$ & 2.812 & .228 & 2.363 & 3.262 \\
\hline
\end{tabular}

\section{Post Hoc Tests}

\section{Experience}

\section{Multiple Comparisons}

Dependent Variable: MOTIVATION

Scheffe

\begin{tabular}{|ll|r|r|r|r|r|}
\hline & & & & & \multicolumn{2}{|c|}{} \\
\cline { 5 - 7 } & & \multicolumn{2}{|c|}{ Mean } & & & \multicolumn{2}{c|}{ 95\% Confidence Interval } \\
\cline { 5 - 7 }$(\mathrm{I})$ Experience & $(\mathrm{J})$ Experience & Difference $(\mathrm{I}-\mathrm{J})$ & Std. Error & \multicolumn{1}{c|}{ Sig. } & Lower Bound & Upper Bound \\
\hline $0-5$ & $6-10$ & -.25 & .191 & .645 & -.78 & .29 \\
& $11-15$ & .06 & .190 & .992 & -.48 & .59 \\
& $15+$ & -.09 & .160 & .956 & -.54 & .36 \\
\hline $6-10$ & $0-5$ & .25 & .191 & .645 & -.29 & .78 \\
& $11-15$ & .31 & .198 & .496 & -.25 & .86 \\
& $15+$ & .16 & .170 & .840 & -.32 & .63 \\
\hline $11-15$ & $0-5$ & -.06 & .190 & .992 & -.59 & .48 \\
& $6-10$ & -.31 & .198 & .496 & -.86 & .25 \\
& $15+$ & -.15 & .169 & .850 & -.63 & .32 \\
\hline $15+$ & $0-5$ & .09 & .160 & .956 & -.36 & .54 \\
& $6-10$ & -.16 & .170 & .840 & -.63 & .32 \\
& $11-15$ & .15 & .169 & .850 & -.32 & .63 \\
\hline
\end{tabular}

Based on observed means. 


\section{Homogeneous Subsets}

MOTIVATION
\begin{tabular}{|l|r|c|} 
Scheffe $^{\mathrm{a}, \mathrm{b}, \mathrm{c}}$ & \\
\hline & & Subset \\
\cline { 3 - 3 } Experience & $\mathrm{N}$ & 1 \\
\hline $11-15$ & 43 & 2.86 \\
$0-5$ & 50 & 2.92 \\
$15+$ & 92 & 3.01 \\
$6-10$ & 42 & 3.17 \\
Sig. & & .411 \\
\hline
\end{tabular}

Means for groups in homogeneous subsets are displayed.

Based on Type III Sum of Squares

The error term is Mean Square(Error) $=.833$.

a. Uses Harmonic Mean Sample Size $=51.325$.

b. The group sizes are unequal. The harmonic mean of the group sizes is used. Type I error levels are not guaranteed.

c. Alpha $=.05$.

Appendix K: 3-way Factorial ANOVA for Barriers

\section{Univariate Analysis of Variance}

Between-Subjects Factors
\begin{tabular}{|ll|l|r|}
\hline & & Value Label & \multicolumn{1}{|c|}{$\mathrm{N}$} \\
\hline Sex & 1 & male & 100 \\
& 2 & female & 127 \\
Academic & 1 & scientific & 135 \\
field & 2 & Humanities & 92 \\
Experience & 0 & $0-5$ & 50 \\
& 1 & $6-10$ & 42 \\
& 2 & $11-15$ & 43 \\
& 3 & $15+$ & 92 \\
\hline
\end{tabular}


Descriptive Statistics

Dependent Variable: BARRIERS

\begin{tabular}{|c|c|c|c|c|c|}
\hline Sex & Academic field & Experience & Mean & Std. Deviation & $\mathrm{N}$ \\
\hline \multirow[t]{15}{*}{ male } & \multirow[t]{5}{*}{ scientific } & $0-5$ & 2.29 & .849 & 17 \\
\hline & & $6-10$ & 2.20 & .447 & 5 \\
\hline & & $11-15$ & 2.50 & .972 & 10 \\
\hline & & $15+$ & 2.54 & .962 & 28 \\
\hline & & Total & 2.43 & .890 & 60 \\
\hline & \multirow[t]{5}{*}{ Humanities } & $0-5$ & 2.71 & .951 & 7 \\
\hline & & $6-10$ & 2.62 & .870 & 13 \\
\hline & & $11-15$ & 3.00 & 1.000 & 5 \\
\hline & & $15+$ & 2.60 & .828 & 15 \\
\hline & & Total & 2.68 & .859 & 40 \\
\hline & \multirow[t]{5}{*}{ Total } & $0-5$ & 2.42 & .881 & 24 \\
\hline & & $6-10$ & 2.50 & .786 & 18 \\
\hline & & $11-15$ & 2.67 & .976 & 15 \\
\hline & & $15+$ & 2.56 & .908 & 43 \\
\hline & & Total & 2.53 & .881 & 100 \\
\hline \multirow[t]{15}{*}{ female } & \multirow[t]{5}{*}{ scientific } & $0-5$ & 2.67 & .907 & 18 \\
\hline & & $6-10$ & 3.18 & .405 & 11 \\
\hline & & $11-15$ & 2.69 & .751 & 13 \\
\hline & & $15+$ & 2.70 & .847 & 33 \\
\hline & & Total & 2.76 & .803 & 75 \\
\hline & \multirow[t]{5}{*}{ Humanities } & $0-5$ & 2.50 & 1.195 & 8 \\
\hline & & $6-10$ & 3.08 & .277 & 13 \\
\hline & & $11-15$ & 2.80 & .775 & 15 \\
\hline & & $15+$ & 3.19 & .655 & 16 \\
\hline & & Total & 2.94 & .752 & 52 \\
\hline & \multirow[t]{5}{*}{ Total } & $0-5$ & 2.62 & .983 & 26 \\
\hline & & $6-10$ & 3.13 & .338 & 24 \\
\hline & & $11-15$ & 2.75 & .752 & 28 \\
\hline & & $15+$ & 2.86 & .816 & 49 \\
\hline & & Total & 2.83 & .784 & 127 \\
\hline \multirow[t]{15}{*}{ Total } & \multirow[t]{5}{*}{ scientific } & $0-5$ & 2.49 & .887 & 35 \\
\hline & & $6-10$ & 2.88 & .619 & 16 \\
\hline & & $11-15$ & 2.61 & .839 & 23 \\
\hline & & $15+$ & 2.62 & .897 & 61 \\
\hline & & Total & 2.61 & .855 & 135 \\
\hline & \multirow[t]{5}{*}{ Humanities } & $0-5$ & 2.60 & 1.056 & 15 \\
\hline & & $6-10$ & 2.85 & .675 & 26 \\
\hline & & $11-15$ & 2.85 & .813 & 20 \\
\hline & & $15+$ & 2.90 & .790 & 31 \\
\hline & & Total & 2.83 & .807 & 92 \\
\hline & \multirow[t]{5}{*}{ Total } & $0-5$ & 2.52 & .931 & 50 \\
\hline & & $6-10$ & 2.86 & .647 & 42 \\
\hline & & $11-15$ & 2.72 & .826 & 43 \\
\hline & & $15+$ & 2.72 & .869 & 92 \\
\hline & & Total & 2.70 & .840 & 227 \\
\hline
\end{tabular}




\section{Levene's Test of Equality of Error Variancess}

Dependent Variable: BARRIERS

\begin{tabular}{|c|c|c|c|}
\hline$F$ & df1 & df2 & Sig. \\
\hline 2.256 & 15 & 211 & .006 \\
\hline
\end{tabular}

Tests the null hypothesis that the error variance of the dependt variable is equal across groups.

a. Design: Intercept+Sex+Afield+Experien+Sex *Afield+Se:

${ }^{*}$ Experien+Afield * Experien+Sex * Afield * Experien

Tests of Between-Subjects Effects

Dependent Variable: BARRIERS

\begin{tabular}{|l|r|r|r|r|r|r|}
\hline Source & $\begin{array}{c}\text { Type III Sum } \\
\text { of Squares }\end{array}$ & df & Mean Square & \multicolumn{1}{c|}{ F } & \multicolumn{1}{c|}{ Sig. } & $\begin{array}{c}\text { Partial Eta } \\
\text { Squared }\end{array}$ \\
\hline Corrected Model & $14.595^{\mathrm{a}}$ & 15 & .973 & 1.416 & .142 & .091 \\
Intercept & 1276.858 & 1 & 1276.858 & 1857.599 & .000 & .898 \\
Sex & 3.744 & 1 & 3.744 & 5.447 & .021 & .025 \\
Afield & 2.034 & 1 & 2.034 & 2.959 & .087 & .014 \\
Experien & 1.498 & 3 & .499 & .727 & .537 & .010 \\
Sex * Afield & .786 & 1 & .786 & 1.143 & .286 & .005 \\
Sex * Experien & 3.054 & 3 & 1.018 & 1.481 & .221 & .021 \\
Afield * Experien & .257 & 3 & .086 & .125 & .946 & .002 \\
Sex * Afield * Experien & 2.626 & 3 & .875 & 1.273 & .284 & .018 \\
Error & 145.035 & 211 & .687 & & & \\
Total & 1815.000 & 227 & & & & \\
Corrected Total & 159.630 & 226 & & & & \\
\hline
\end{tabular}

a. $\mathrm{R}$ Squared $=.091$ (Adjusted $\mathrm{R}$ Squared $=.027$ )

\section{Estimated Marginal Means}

\section{Grand Mean}

Dependent Variable: BARRIERS

\begin{tabular}{|c|r|r|r|}
\hline & & \multicolumn{2}{|c|}{$95 \%$ Confidence Interval } \\
\cline { 3 - 4 } Mean & Std. Error & Lower Bound & Upper Bound \\
\hline 2.704 & .063 & 2.580 & 2.828 \\
\hline
\end{tabular}

\section{Sex}




\section{Estimates}

Dependent Variable: BARRIERS

\begin{tabular}{|l|r|r|r|r|}
\hline & & & \multicolumn{2}{|c|}{$95 \%$ Confidence Interval } \\
\cline { 4 - 5 } Sex & Mean & Std. Error & Lower Bound & Upper Bound \\
\hline male & 2.557 & .097 & 2.366 & 2.749 \\
female & 2.850 & .079 & 2.694 & 3.006 \\
\hline
\end{tabular}

\section{Pairwise Comparisons}

Dependent Variable: BARRIERS

\begin{tabular}{|c|c|c|c|c|c|c|}
\hline \multirow[b]{2}{*}{ (I) Sex } & \multirow[b]{2}{*}{ (J) Sex } & \multirow{2}{*}{$\begin{array}{c}\text { Mean } \\
\text { Difference (I-J) }\end{array}$} & \multirow[b]{2}{*}{ Std. Error } & \multirow[b]{2}{*}{ Sig. ${ }^{a}$} & \multicolumn{2}{|c|}{$\begin{array}{c}\text { 95\% Confidence Interval for } \\
\text { Difference }\end{array}$} \\
\hline & & & & & Lower Bound & Upper Bound \\
\hline male & female & $-.293^{*}$ & .125 & .021 & -.540 & -.046 \\
\hline female & male & $.293^{*}$ & .125 & .021 & .046 & .540 \\
\hline
\end{tabular}

Based on estimated marginal means

*. The mean difference is significant at the .05 level.

a. Adjustment for multiple comparisons: Least Significant Difference (equivalent to no adjustments).

\section{Univariate Tests}

Dependent Variable: BARRIERS

\begin{tabular}{|l|r|r|r|r|r|r|}
\hline & $\begin{array}{c}\text { Sum of } \\
\text { Squares }\end{array}$ & df & Mean Square & F & Sig. & $\begin{array}{c}\text { Partial Eta } \\
\text { Squared }\end{array}$ \\
\hline Contrast & 3.744 & 1 & 3.744 & 5.447 & .021 & .025 \\
Error & 145.035 & 211 & .687 & & & \\
\hline
\end{tabular}

The $\mathrm{F}$ tests the effect of Sex. This test is based on the linearly independent pairwise compi among the estimated marginal means.

\section{Academic field}

\section{Estimates}

Dependent Variable: BARRIERS

\begin{tabular}{|l|r|r|r|r|}
\hline & & & \multicolumn{2}{|c|}{$95 \%$ Confidence Interval } \\
\cline { 4 - 5 } Academic field & Mean & Std. Error & Lower Bound & Upper Bound \\
\hline scientific & 2.596 & .083 & 2.431 & 2.760 \\
Humanities & 2.812 & .094 & 2.627 & 2.996 \\
\hline
\end{tabular}


Pairwise Comparisons

Dependent Variable: BARRIERS

\begin{tabular}{|c|c|c|c|c|c|}
\hline \multirow[b]{2}{*}{ (I) Academic field ( $\mathrm{J}$ ) Academic field } & \multirow{2}{*}{$\begin{array}{c}\text { Mean } \\
\text { Difference (I-J) }\end{array}$} & \multirow[b]{2}{*}{ Std. Error } & \multirow[b]{2}{*}{ Sig. ${ }^{a}$} & \multicolumn{2}{|c|}{$\begin{array}{l}\text { 95\% Confidence Interval for } \\
\text { Difference } \\
\text { Da }\end{array}$} \\
\hline & & & & Lower Bound & Upper Bound \\
\hline $\begin{array}{ll}\text { scientific } & \text { Humanities }\end{array}$ & -.216 & .125 & .087 & -.463 & .032 \\
\hline Humanities & .216 & .125 & .087 & -.032 & .463 \\
\hline
\end{tabular}

Based on estimated marginal means

a. Adjustment for multiple comparisons: Least Significant Difference (equivalent to no adjustments).

\section{Univariate Tests}

Dependent Variable: BARRIERS

\begin{tabular}{|l|r|r|r|r|r|r|}
\hline & $\begin{array}{c}\text { Sum of } \\
\text { Squares }\end{array}$ & df & Mean Square & F & Sig. & $\begin{array}{c}\text { Partial Eta } \\
\text { Squared }\end{array}$ \\
\hline Contrast & 2.034 & 1 & 2.034 & 2.959 & .087 & .014 \\
Error & 145.035 & 211 & .687 & & & \\
\hline
\end{tabular}

The $\mathrm{F}$ tests the effect of Academic field. This test is based on the linearly independent pair comparisons among the estimated marginal means.

\section{Experience}

\section{Estimates}

Dependent Variable: BARRIERS

\begin{tabular}{|l|r|r|r|r|}
\hline & & & \multicolumn{2}{|c|}{$95 \%$ Confidence Interval } \\
\cline { 4 - 5 } Experience & Mean & Std. Error & Lower Bound & Upper Bound \\
\hline $0-5$ & 2.544 & .128 & 2.291 & 2.796 \\
$6-10$ & 2.769 & .138 & 2.496 & 3.041 \\
$11-15$ & 2.748 & .138 & 2.476 & 3.020 \\
$15+$ & 2.755 & .092 & 2.575 & 2.936 \\
\hline
\end{tabular}


Pairwise Comparisons

Dependent Variable: BARRIERS

\begin{tabular}{|c|c|c|c|c|c|c|}
\hline & & Mean & & & $\begin{array}{r}\text { 95\% Confiden } \\
\text { Diffe }\end{array}$ & $\begin{array}{l}\text { ce Interval for } \\
\text { ence } \\
\text { ence }\end{array}$ \\
\hline (I) Experience & (J) Experience & Difference $(\mathrm{I}-\mathrm{J})$ & Std. Error & Sig. ${ }^{a}$ & Lower Bound & Upper Bound \\
\hline $0-5$ & $6-10$ & -.225 & .188 & .234 & -.596 & .147 \\
\hline & $11-15$ & -.204 & .188 & 279 & -.576 & 167 \\
\hline & $15+$ & -.211 & 158 & 181 & -.522 & .099 \\
\hline $6-10$ & $0-5$ & .225 & .188 & .234 & -.147 & .596 \\
\hline & $11-15$ & .020 & 195 & .917 & -.365 & .406 \\
\hline & $15+$ & .013 & 166 & .935 & -.313 & .340 \\
\hline $11-15$ & $0-5$ & .204 & .188 & .279 & -.167 & .576 \\
\hline & $6-10$ & -.020 & .195 & .917 & -.406 & .365 \\
\hline & $15+$ & -.007 & .166 & .966 & -.334 & .320 \\
\hline $15+$ & $0-5$ & 211 & 158 & 181 & -.099 & .522 \\
\hline & $6-10$ & -.013 & 166 & .935 & -.340 & .313 \\
\hline & $11-15$ & .007 & .166 & .966 & -.320 & .334 \\
\hline
\end{tabular}

Based on estimated marginal means

a. Adjustment for multiple comparisons: Least Significant Difference (equivalent to no adjustments).

Univariate Tests

Dependent Variable: BARRIERS

\begin{tabular}{|l|r|r|r|r|r|r|}
\hline & $\begin{array}{c}\text { Sum of } \\
\text { Squares }\end{array}$ & \multicolumn{1}{c|}{$\mathrm{df}$} & Mean Square & $\mathrm{F}$ & \multicolumn{1}{c|}{ Sig. } & $\begin{array}{c}\text { Partial Eta } \\
\text { Squared }\end{array}$ \\
\hline Contrast & 1.498 & 3 & .499 & .727 & .537 & .010 \\
Error & 145.035 & 211 & .687 & & & \\
\hline
\end{tabular}

The $\mathrm{F}$ tests the effect of Experience. This test is based on the linearly independent pairwis comparisons among the estimated marginal means.

\section{Sex * Academic field}

Dependent Variable: BARRIERS

\begin{tabular}{|ll|r|r|r|r|}
\hline & & & \multicolumn{2}{|c|}{$95 \%$ Confidence Interval } \\
\cline { 5 - 6 } Sex & Academic field & Mean & Std. Error & Lower Bound & Upper Bound \\
\hline male & Scientific & 2.382 & .130 & 2.126 & 2.639 \\
& Humanities & 2.732 & .145 & 2.447 & 3.017 \\
\hline female & scientific & 2.809 & .104 & 2.604 & 3.015 \\
& Humanities & 2.891 & .119 & 2.656 & 3.126 \\
\hline
\end{tabular}


6. Sex * Experience

Dependent Variable: BARRIERS

\begin{tabular}{|ll|r|r|r|r|}
\hline & & & \multicolumn{2}{|c|}{$95 \%$ Confidence Interval } \\
\cline { 5 - 6 } Sex & Experience & Mean & Std. Error & Lower Bound & Upper Bound \\
\hline male & $0-5$ & 2.504 & .186 & 2.137 & 2.871 \\
& $6-10$ & 2.408 & .218 & 1.978 & 2.838 \\
& $11-15$ & 2.750 & .227 & 2.302 & 3.198 \\
& $15+$ & 2.568 & .133 & 2.306 & 2.829 \\
\hline female & $0-5$ & 2.583 & .176 & 2.236 & 2.931 \\
& $6-10$ & 3.129 & .170 & 2.795 & 3.464 \\
& $11-15$ & 2.746 & .157 & 2.437 & 3.056 \\
$15+$ & 2.942 & .126 & 2.693 & 3.191 \\
\hline
\end{tabular}

\section{Academic field * Experience}

Dependent Variable: BARRIERS

\begin{tabular}{|ll|r|r|r|r|}
\hline & & & & \multicolumn{2}{|c|}{$95 \%$ Confidence Interval } \\
\cline { 5 - 6 } Academic field & Experience & Mean & Std. Error & Lower Bound & Upper Bound \\
\hline scientific & $0-5$ & 2.480 & .140 & 2.204 & 2.757 \\
& $6-10$ & 2.691 & .224 & 2.250 & 3.132 \\
& $11-15$ & 2.596 & .174 & 2.252 & 2.940 \\
& $15+$ & 2.616 & .107 & 2.406 & 2.826 \\
\hline Humanities & $0-5$ & 2.607 & .215 & 2.184 & 3.030 \\
& $6-10$ & 2.846 & .163 & 2.526 & 3.167 \\
& $11-15$ & 2.900 & .214 & 2.478 & 3.322 \\
& $15+$ & 2.894 & .149 & 2.600 & 3.187 \\
\hline
\end{tabular}




\section{Sex * Academic field * Experience}

Dependent Variable: BARRIERS

\begin{tabular}{|c|c|c|c|c|c|c|}
\hline \multirow[b]{2}{*}{ Sex } & \multirow[b]{2}{*}{ Academic field } & \multirow[b]{2}{*}{ Experience } & \multirow[b]{2}{*}{ Mean } & \multirow[b]{2}{*}{ Std. Error } & \multicolumn{2}{|c|}{ 95\% Confidence Interval } \\
\hline & & & & & Lower Bound & Upper Bound \\
\hline \multirow[t]{8}{*}{ male } & scientific & $0-5$ & 2.294 & .201 & 1.898 & 2.691 \\
\hline & & $6-10$ & 2.200 & 371 & 1.469 & 2.931 \\
\hline & & $11-15$ & 2.500 & 262 & 1.983 & 3.017 \\
\hline & & $15+$ & 2.536 & 157 & 2.227 & 2.845 \\
\hline & Humanities & $0-5$ & 2.714 & .313 & 2.097 & 3.332 \\
\hline & & $6-10$ & 2.615 & .230 & 2.162 & 3.069 \\
\hline & & $11-15$ & 3.000 & .371 & 2.269 & 3.731 \\
\hline & & $15+$ & 2.600 & 214 & 2.178 & 3.022 \\
\hline \multirow[t]{8}{*}{ female } & scientific & $0-5$ & 2.667 & .195 & 2.281 & 3.052 \\
\hline & & $6-10$ & 3.182 & .250 & 2.689 & 3.675 \\
\hline & & $11-15$ & 2.692 & .230 & 2.239 & 3.146 \\
\hline & & $15+$ & 2.697 & .144 & 2.412 & 2.981 \\
\hline & Humanities & $0-5$ & 2.500 & .293 & 1.922 & 3.078 \\
\hline & & $6-10$ & 3.077 & .230 & 2.624 & 3.530 \\
\hline & & $11-15$ & 2.800 & .214 & 2.378 & 3.222 \\
\hline & & $15+$ & 3.187 & .207 & 2.779 & 3.596 \\
\hline
\end{tabular}

\section{Post Hoc Tests}

\section{Experience}

\section{Multiple Comparisons}

Dependent Variable: BARRIERS

Scheffe

\begin{tabular}{|c|c|c|c|c|c|c|}
\hline \multirow[b]{2}{*}{ (I) Experience } & \multirow[b]{2}{*}{ (J) Experience } & \multirow{2}{*}{$\begin{array}{c}\text { Mean } \\
\text { Difference (I-J) }\end{array}$} & \multirow[b]{2}{*}{ Std. Error } & \multirow[b]{2}{*}{ Sig. } & \multicolumn{2}{|c|}{ 95\% Confidence Interval } \\
\hline & & & & & Lower Bound & Upper Bound \\
\hline \multirow[t]{3}{*}{$0-5$} & $6-10$ & -.34 & .174 & .290 & -.83 & .15 \\
\hline & $11-15$ & -.20 & .172 & .716 & -.69 & .29 \\
\hline & $15+$ & -.20 & .146 & .608 & -.61 & .21 \\
\hline \multirow[t]{3}{*}{$6-10$} & $0-5$ & .34 & .174 & .290 & -.15 & .83 \\
\hline & $11-15$ & .14 & .180 & .902 & -.37 & .64 \\
\hline & $15+$ & .14 & .154 & .845 & -.30 & .57 \\
\hline \multirow[t]{3}{*}{$11-15$} & $0-5$ & .20 & .172 & .716 & -.29 & .69 \\
\hline & $6-10$ & -.14 & .180 & .902 & -.64 & .37 \\
\hline & $15+$ & .00 & .153 & 1.000 & -.43 & .44 \\
\hline \multirow[t]{3}{*}{$15+$} & $0-5$ & .20 & .146 & .608 & -.21 & .61 \\
\hline & $6-10$ & -.14 & .154 & .845 & -.57 & .30 \\
\hline & $11-15$ & .00 & .153 & 1.000 & -.44 & .43 \\
\hline
\end{tabular}

Based on observed means. 


\section{Homogeneous Subsets}

BARRIERS
\begin{tabular}{|l|r|c|} 
Scheffe ${ }^{\mathrm{a}, \mathrm{b}, \mathrm{c}}$ & \\
\hline & & Subset \\
\cline { 3 - 3 } Experience & $\mathrm{N}$ & 1 \\
\hline $0-5$ & 50 & 2.52 \\
$15+$ & 92 & 2.72 \\
$11-15$ & 43 & 2.72 \\
$6-10$ & 42 & 2.86 \\
Sig. & & .240 \\
\hline
\end{tabular}

Means for groups in homogeneous subsets are displayed.

Based on Type III Sum of Squares

The error term is Mean Square(Error) $=.687$.

a. Uses Harmonic Mean Sample Size $=51.325$.

b. The group sizes are unequal. The harmonic mean of the group sizes is used. Type I error levels are not guaranteed.

c. Alpha $=.05$. 


\section{Appendix L: Factor Analysis for technology expertise}

KMO and Bartlett's Test

\begin{tabular}{|c|c|c|}
\hline \multicolumn{2}{|c|}{$\begin{array}{l}\text { Kaiser-Meyer-Olkin Measure of Sampling } \\
\text { Adequacy. }\end{array}$} & 902 \\
\hline $\begin{array}{l}\text { Bartlett's Test of } \\
\text { Sphericity }\end{array}$ & $\begin{array}{l}\text { Approx. Chi-Square } \\
\text { df } \\
\text { Sig. }\end{array}$ & $\begin{array}{r}1922.420 \\
66 \\
.000\end{array}$ \\
\hline
\end{tabular}

\section{Communalities}

\begin{tabular}{|c|c|c|}
\hline & Initial & Extraction \\
\hline $\begin{array}{l}\text { 1- Use a word processor } \\
\text { to create documents. }\end{array}$ & 1.000 & .756 \\
\hline $\begin{array}{l}2-\text { Use a spreadsheet to } \\
\text { create charts and graphs. }\end{array}$ & 1.000 & .672 \\
\hline $\begin{array}{l}\text { 3- Use a computer to find } \\
\text { resources from the } \\
\text { university library. }\end{array}$ & 1.000 & .780 \\
\hline $\begin{array}{l}\text { 4- Searching the web to } \\
\text { find information and } \\
\text { resources. }\end{array}$ & 1.000 & .631 \\
\hline $\begin{array}{l}\text { 5- Use a database } \\
\text { software to set up and } \\
\text { access information. }\end{array}$ & 1.000 & .557 \\
\hline $\begin{array}{l}\text { 6- Use presentation } \\
\text { software (e.g., } \\
\text { PowerPoint). }\end{array}$ & 1.000 & .702 \\
\hline $\begin{array}{l}\text { 7- Use graphic software } \\
\text { to create illustrations, } \\
\text { slides, or images. }\end{array}$ & 1.000 & .642 \\
\hline $\begin{array}{l}\text { 8- Use audio/video clips } \\
\text { software to create or } \\
\text { enhance presentations. }\end{array}$ & 1.000 & .632 \\
\hline 9- Website design. & 1.000 & .671 \\
\hline $\begin{array}{l}\text { 10- Use a computer to } \\
\text { communicate with others. }\end{array}$ & 1.000 & .623 \\
\hline $\begin{array}{l}11-\text { Use of electronic } \\
\text { bulletin board. }\end{array}$ & 1.000 & .854 \\
\hline $\begin{array}{l}\text { 12- Use video } \\
\text { conferencing }\end{array}$ & 1.000 & .806 \\
\hline
\end{tabular}

Extraction Method: Principal Component Analysis. 
Total Variance Explained

\begin{tabular}{|c|c|c|c|c|c|c|c|c|c|}
\hline \multirow{2}{*}{$\begin{array}{l}\mathrm{C} \\
\mathrm{o} \\
\mathrm{m} \\
\mathrm{p}-\end{array}$} & \multicolumn{3}{|c|}{ Initial Eigenvalues } & \multicolumn{3}{|c|}{$\begin{array}{c}\text { Extraction Sums of Squared } \\
\text { Loadings }\end{array}$} & \multicolumn{3}{|c|}{$\begin{array}{c}\text { Rotation Sums of Squared } \\
\text { Loadings }\end{array}$} \\
\hline & Total & $\begin{array}{c}\text { \% of } \\
\text { Variance }\end{array}$ & $\begin{array}{l}\text { Cumulati } \\
\text { ve } \%\end{array}$ & Total & $\begin{array}{c}\text { \% of } \\
\text { Variance }\end{array}$ & $\begin{array}{l}\text { Cumulati } \\
\text { ve } \%\end{array}$ & Total & $\begin{array}{c}\% \text { of } \\
\text { Variance }\end{array}$ & $\begin{array}{l}\text { Cumulati } \\
\text { ve } \%\end{array}$ \\
\hline 1 & 6.756 & 56.301 & 56.301 & 6.756 & 56.301 & 56.301 & 4.866 & 40.549 & 40.549 \\
\hline 2 & 1.570 & 13.082 & 69.383 & 1.570 & 13.082 & 69.383 & 3.460 & 28.834 & 69.383 \\
\hline 3 & .697 & 5.808 & 75.190 & & & & & & \\
\hline 4 & .559 & 4.661 & 79.851 & & & & & & \\
\hline 5 & .428 & 3.569 & 83.421 & & & & & & \\
\hline 6 & .402 & 3.351 & 86.772 & & & & & & \\
\hline 7 & .389 & 3.240 & 90.012 & & & & & & \\
\hline 8 & .362 & 3.018 & 93.030 & & & & & & \\
\hline 9 & .282 & 2.352 & 95.382 & & & & & & \\
\hline 10 & .234 & 1.951 & 97.334 & & & & & & \\
\hline 11 & 176 & 1.468 & 98.802 & & & & & & \\
\hline 12 & .144 & 1.198 & 100.000 & & & & & & \\
\hline
\end{tabular}

Extraction Method: Principal Component Analysis. 


\section{Scree Plot}

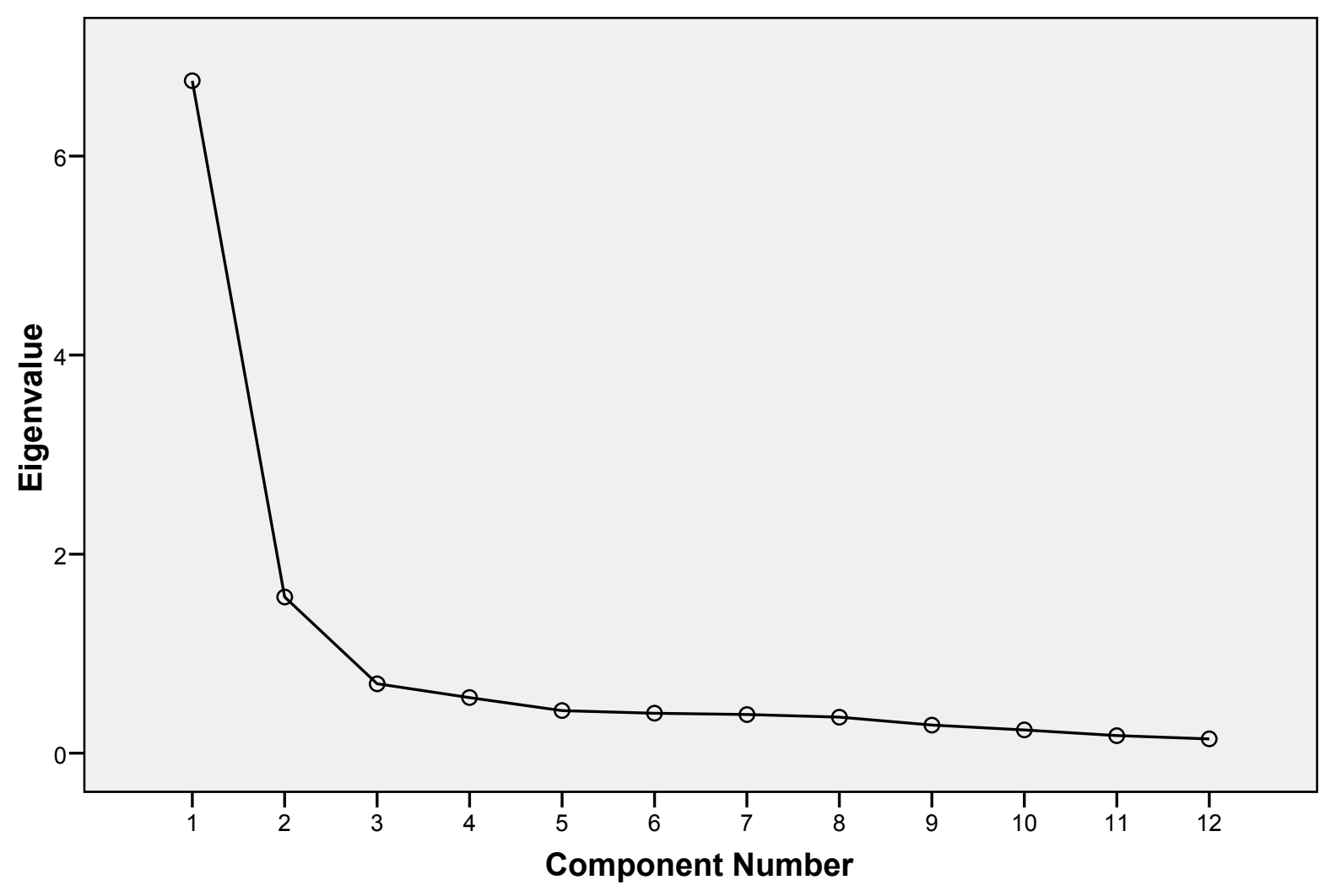


Component Matrix

\begin{tabular}{|c|c|c|}
\hline & \multicolumn{2}{|c|}{ Component } \\
\hline & 1 & 2 \\
\hline $\begin{array}{l}\text { 1- Use a word processor } \\
\text { to create documents. }\end{array}$ & .766 & -.412 \\
\hline $\begin{array}{l}\text { 2- Use a spreadsheet to } \\
\text { create charts and graphs. }\end{array}$ & .797 & -.191 \\
\hline $\begin{array}{l}\text { 3- Use a computer to find } \\
\text { resources from the } \\
\text { university library. }\end{array}$ & .750 & -.467 \\
\hline $\begin{array}{l}\text { 4- Searching the web to } \\
\text { find information and } \\
\text { resources. }\end{array}$ & .772 & -.188 \\
\hline $\begin{array}{l}\text { 5- Use a database } \\
\text { software to set up and } \\
\text { access information. }\end{array}$ & .745 & -.041 \\
\hline $\begin{array}{l}\text { 6- Use presentation } \\
\text { software (e.g., } \\
\text { PowerPoint). }\end{array}$ & .766 & -.340 \\
\hline $\begin{array}{l}\text { 7- Use graphic software } \\
\text { to create illustrations, } \\
\text { slides, or images. }\end{array}$ & .801 & -.025 \\
\hline $\begin{array}{l}\text { 8- Use audio/video clips } \\
\text { software to create or } \\
\text { enhance presentations. }\end{array}$ & .779 & .159 \\
\hline 9- Website design. & .690 & .441 \\
\hline $\begin{array}{l}\text { 10- Use a computer to } \\
\text { communicate with others. }\end{array}$ & .789 & .025 \\
\hline $\begin{array}{l}\text { 11- Use of electronic } \\
\text { bulletin board. }\end{array}$ & .690 & .614 \\
\hline $\begin{array}{l}\text { 12- Use video } \\
\text { conferencing }\end{array}$ & .642 & .628 \\
\hline
\end{tabular}

Extraction Method: Principal Component Analysis.

a. 2 components extracted. 
Rotated Component Matrix

\begin{tabular}{|l|c|c|}
\hline & \multicolumn{2}{|c|}{ Component } \\
\cline { 2 - 3 } & 1 & 2 \\
\hline $\begin{array}{l}\text { 1- Use a word processor } \\
\text { to create documents. }\end{array}$ & .859 & \\
2- Use a spreadsheet to \\
create charts and graphs. & .751 & \\
3- Use a computer to find \\
resources from the \\
university library. \\
4- Searching the web to \\
find information and \\
resources. \\
$\begin{array}{l}\text { 5- Use a database } \\
\text { software to set up and } \\
\text { access information. } \\
\text { 6- Use presentation } \\
\text { software (e.g., }\end{array}$
\end{tabular}

Extraction Method: Principal Component Analysis.

Rotation Method: Varimax with Kaiser Normalization.

a. Rotation converged in 3 iterations.

\section{Component Transformation Matrix}

\begin{tabular}{|l|r|r|}
\hline Component & \multicolumn{1}{|c|}{1} & 2 \\
\hline 1 & .797 & .604 \\
2 & -.604 & .797 \\
\hline
\end{tabular}

Extraction Method: Principal Component Analysis.

Rotation Method: Varimax with Kaiser Normalization. 


\section{Component Plot in Rotated Space}

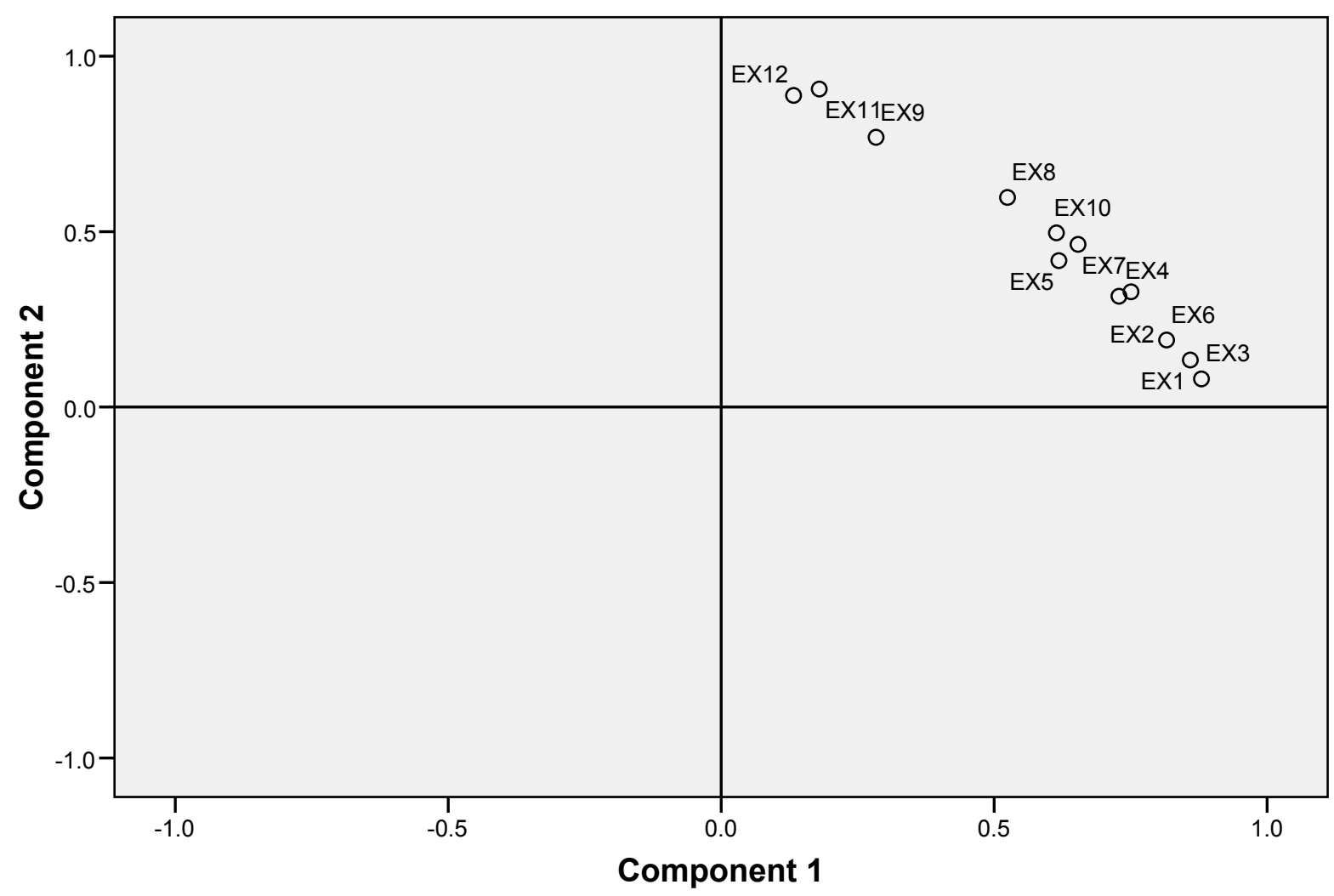

Appendix M: Factor Analysis for current usage of e-learning KMO and Bartlett's Test

Kaiser-Meyer-Olkin Measure of Sampling Adequacy.

Bartlett's Test of

Approx. Chi-Square

1921.710

Sphericity

df

105

Sig.

.000 
Communalities

\begin{tabular}{|c|c|c|}
\hline & Initial & Extraction \\
\hline $\begin{array}{l}\text { 1- Use of computer } \\
\text { software for handouts } \\
\text { or lecture notes. }\end{array}$ & 1.000 & .687 \\
\hline $\begin{array}{l}\text { 2- Use Email as the } \\
\text { primary source of } \\
\text { student contact outside } \\
\text { the classroom. }\end{array}$ & 1.000 & .627 \\
\hline $\begin{array}{l}\text { 3- Hold virtual office } \\
\text { hours. }\end{array}$ & 1.000 & .334 \\
\hline $\begin{array}{l}\text { 4- Use of presentation } \\
\text { software in the } \\
\text { classroom. }\end{array}$ & 1.000 & .706 \\
\hline $\begin{array}{l}\text { 5- Use On-line bulletin } \\
\text { board. }\end{array}$ & 1.000 & .633 \\
\hline $\begin{array}{l}\text { 6- Use personally } \\
\text { designed Web-based } \\
\text { lectures, notes, or } \\
\text { tutorials. }\end{array}$ & 1.000 & .794 \\
\hline $\begin{array}{l}\text { 7- Use personally } \\
\text { designed Web-based } \\
\text { tests or quizzes. }\end{array}$ & 1.000 & .739 \\
\hline $\begin{array}{l}\text { 8- Provided web-based } \\
\text { grades. }\end{array}$ & 1.000 & .613 \\
\hline $\begin{array}{l}\text { 9- Used Internet } \\
\text { research and searches. }\end{array}$ & 1.000 & .474 \\
\hline $\begin{array}{l}10-\text { Posting required } \\
\text { readings on course } \\
\text { web page. }\end{array}$ & 1.000 & .592 \\
\hline $\begin{array}{l}\text { 11- Use On-line Chat } \\
\text { room }\end{array}$ & 1.000 & .557 \\
\hline $\begin{array}{l}\text { 12- Commenting on } \\
\text { course work } \\
\text { electronically. }\end{array}$ & 1.000 & .657 \\
\hline $\begin{array}{l}\text { 13- Electronics } \\
\text { conferencing. }\end{array}$ & 1.000 & .792 \\
\hline $\begin{array}{l}\text { 14- Use video tapes for } \\
\text { instruction. }\end{array}$ & 1.000 & .789 \\
\hline $\begin{array}{l}\text { 15- Use audio tapes for } \\
\text { instruction. }\end{array}$ & 1.000 & .756 \\
\hline
\end{tabular}

Extraction Method: Principal Component Analysis. 
Total Variance Explained

\begin{tabular}{|c|c|c|c|c|c|c|c|c|c|}
\hline \multirow{2}{*}{$\begin{array}{l}\text { Co } \\
\text { m } \\
\text { p. }\end{array}$} & \multicolumn{3}{|c|}{ Initial Eigenvalues } & \multicolumn{3}{|c|}{$\begin{array}{c}\text { Extraction Sums of Squared } \\
\text { Loadings }\end{array}$} & \multicolumn{3}{|c|}{$\begin{array}{c}\text { Rotation Sums of Squared } \\
\text { Loadings }\end{array}$} \\
\hline & Total & $\begin{array}{c}\% \text { of } \\
\text { Variance }\end{array}$ & $\begin{array}{l}\text { Cumulati } \\
\text { ve } \%\end{array}$ & Total & $\begin{array}{c}\% \text { of } \\
\text { Variance }\end{array}$ & $\begin{array}{l}\text { Cumulati } \\
\text { ve } \%\end{array}$ & Total & $\begin{array}{c}\% \text { of } \\
\text { Variance }\end{array}$ & $\begin{array}{l}\text { Cumulati } \\
\text { ve } \%\end{array}$ \\
\hline 1 & 6.722 & 44.815 & 44.815 & 6.722 & 44.815 & 44.815 & 4.885 & 32.570 & 32.570 \\
\hline 2 & 1.942 & 12.944 & 57.759 & 1.942 & 12.944 & 57.759 & 3.185 & 21.231 & 53.800 \\
\hline 3 & 1.088 & 7.256 & 65.015 & 1.088 & 7.256 & 65.015 & 1.682 & 11.215 & 65.015 \\
\hline 4 & .826 & 5.509 & 70.524 & & & & & & \\
\hline 5 & .802 & 5.346 & 75.870 & & & & & & \\
\hline 6 & .619 & 4.123 & 79.994 & & & & & & \\
\hline 7 & .548 & 3.654 & 83.647 & & & & & & \\
\hline 8 & .473 & 3.155 & 86.803 & & & & & & \\
\hline 9 & .398 & 2.655 & 89.457 & & & & & & \\
\hline 10 & .366 & 2.439 & 91.896 & & & & & & \\
\hline 11 & .335 & 2.235 & 94.131 & & & & & & \\
\hline 12 & .299 & 1.994 & 96.125 & & & & & & \\
\hline 13 & .233 & 1.554 & 97.679 & & & & & & \\
\hline 14 & .181 & 1.205 & 98.884 & & & & & & \\
\hline 15 & .167 & 1.116 & 100.000 & & & & & & \\
\hline
\end{tabular}

Extraction Method: Principal Component Analysis. 


\section{Scree Plot}

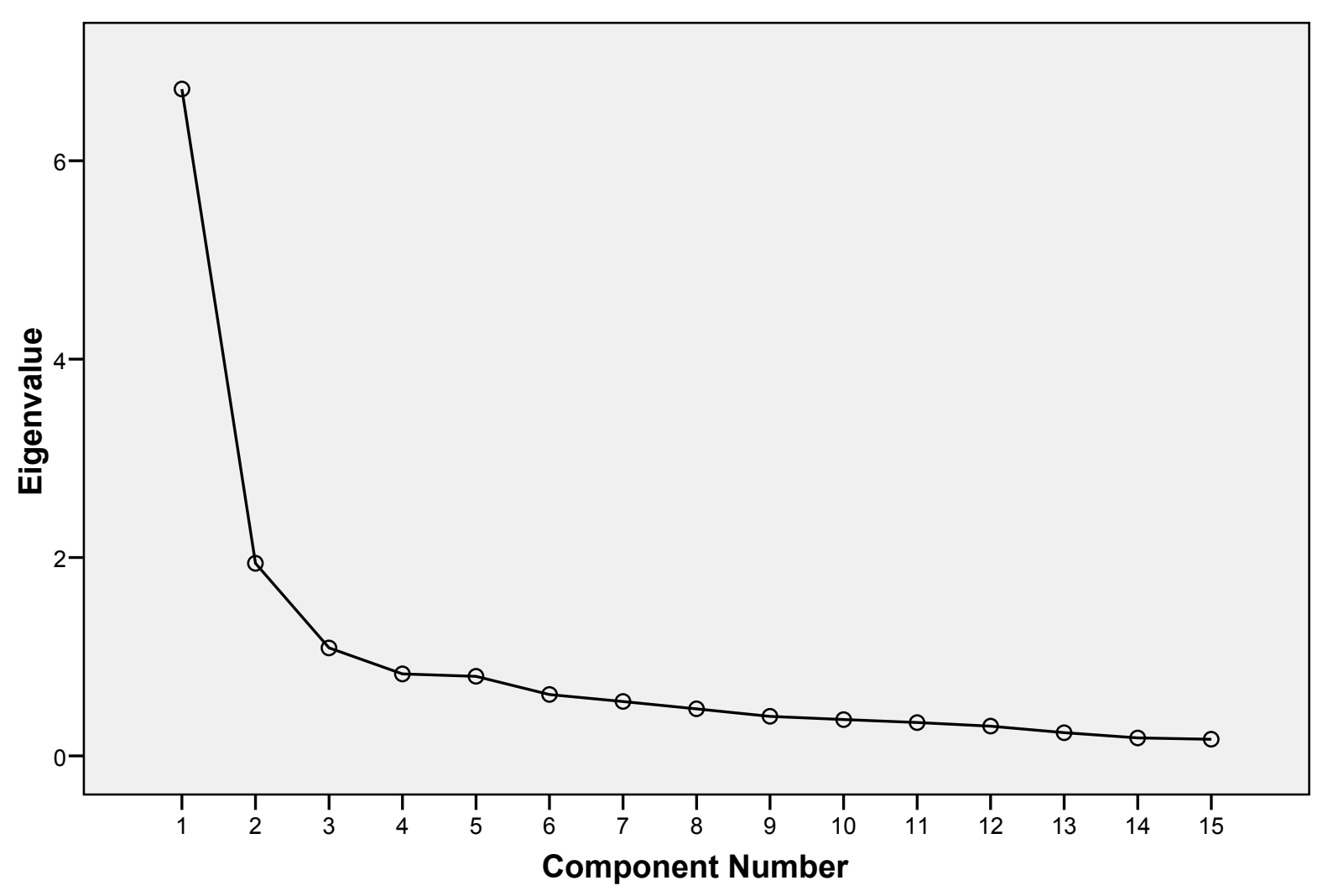


Component Matrix

\begin{tabular}{|c|c|c|c|}
\hline & \multicolumn{3}{|c|}{ Component } \\
\hline & 1 & 2 & 3 \\
\hline $\begin{array}{l}\text { 1- Use of computer } \\
\text { software for handouts } \\
\text { or lecture notes. }\end{array}$ & .489 & .669 & .034 \\
\hline $\begin{array}{l}\text { 2- Use Email as the } \\
\text { primary source of } \\
\text { student contact outside } \\
\text { the classroom. }\end{array}$ & .688 & .350 & -.176 \\
\hline $\begin{array}{l}\text { 3- Hold virtual office } \\
\text { hours. }\end{array}$ & .577 & .028 & -.025 \\
\hline $\begin{array}{l}\text { 4- Use of presentation } \\
\text { software in the } \\
\text { classroom. }\end{array}$ & .653 & .525 & .071 \\
\hline $\begin{array}{l}\text { 5- Use On-line bulletin } \\
\text { board. }\end{array}$ & .775 & -.149 & .103 \\
\hline $\begin{array}{l}\text { 6- Use personally } \\
\text { designed Web-based } \\
\text { lectures, notes, or } \\
\text { tutorials. }\end{array}$ & .802 & -.382 & -.070 \\
\hline $\begin{array}{l}\text { 7- Use personally } \\
\text { designed Web-based } \\
\text { tests or quizzes. }\end{array}$ & .729 & -.441 & -.113 \\
\hline $\begin{array}{l}\text { 8- Provided web-based } \\
\text { grades. }\end{array}$ & .558 & .197 & -.512 \\
\hline $\begin{array}{l}\text { 9- Used Internet } \\
\text { research and searches. }\end{array}$ & .322 & .592 & .141 \\
\hline $\begin{array}{l}10-\text { Posting required } \\
\text { readings on course } \\
\text { web page. }\end{array}$ & .673 & .281 & -.244 \\
\hline $\begin{array}{l}\text { 11- Use On-line Chat } \\
\text { room }\end{array}$ & .689 & -.269 & -.105 \\
\hline $\begin{array}{l}\text { 12- Commenting on } \\
\text { course work } \\
\text { electronically. }\end{array}$ & .771 & -.197 & -.153 \\
\hline $\begin{array}{l}\text { 13- Electronics } \\
\text { conferencing. }\end{array}$ & .811 & -.365 & -.031 \\
\hline $\begin{array}{l}\text { 14- Use video tapes for } \\
\text { instruction. }\end{array}$ & .696 & .061 & .549 \\
\hline $\begin{array}{l}\text { 15- Use audio tapes for } \\
\text { instruction. }\end{array}$ & .629 & -.130 & .586 \\
\hline
\end{tabular}

Extraction Method: Principal Component Analysis.

a. 3 components extracted. 
Rotated Component Matrix

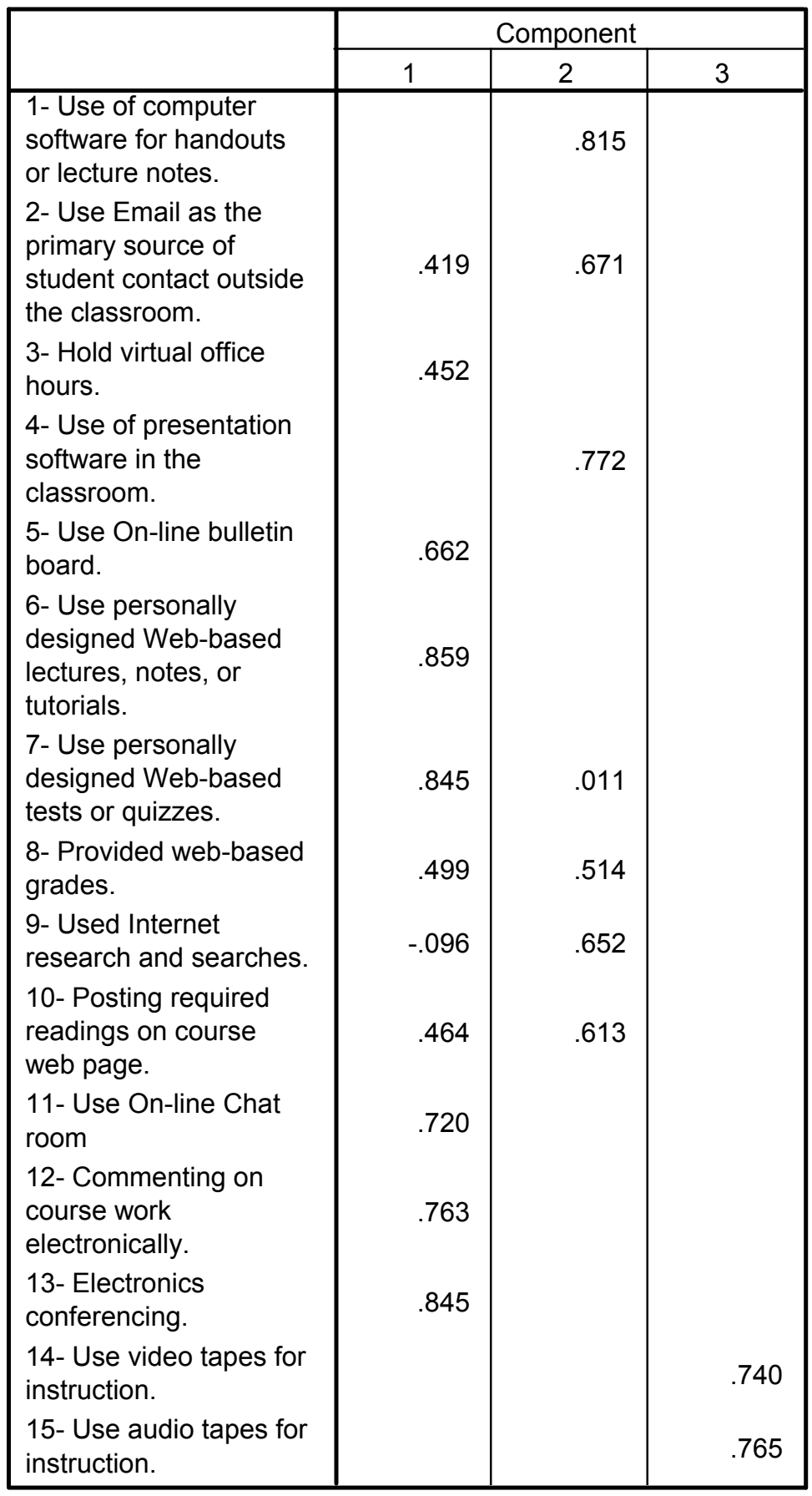

Extraction Method: Principal Component Analysis.

Rotation Method: Varimax with Kaiser Normalization.

a. Rotation converged in 5 iterations. 
Component Transformation Matrix

\begin{tabular}{|l|r|r|r|}
\hline Component & \multicolumn{1}{|l|}{1} & \multicolumn{1}{|c|}{2} & \multicolumn{1}{l|}{3} \\
\hline 1 & .795 & .512 & .324 \\
2 & -.522 & .851 & -.065 \\
3 & -.309 & -.117 & .944 \\
\hline
\end{tabular}

Extraction Method: Principal Component Analysis.

Rotation Method: Varimax with Kaiser Normalization.

\section{Component Plot in Rotated Space}

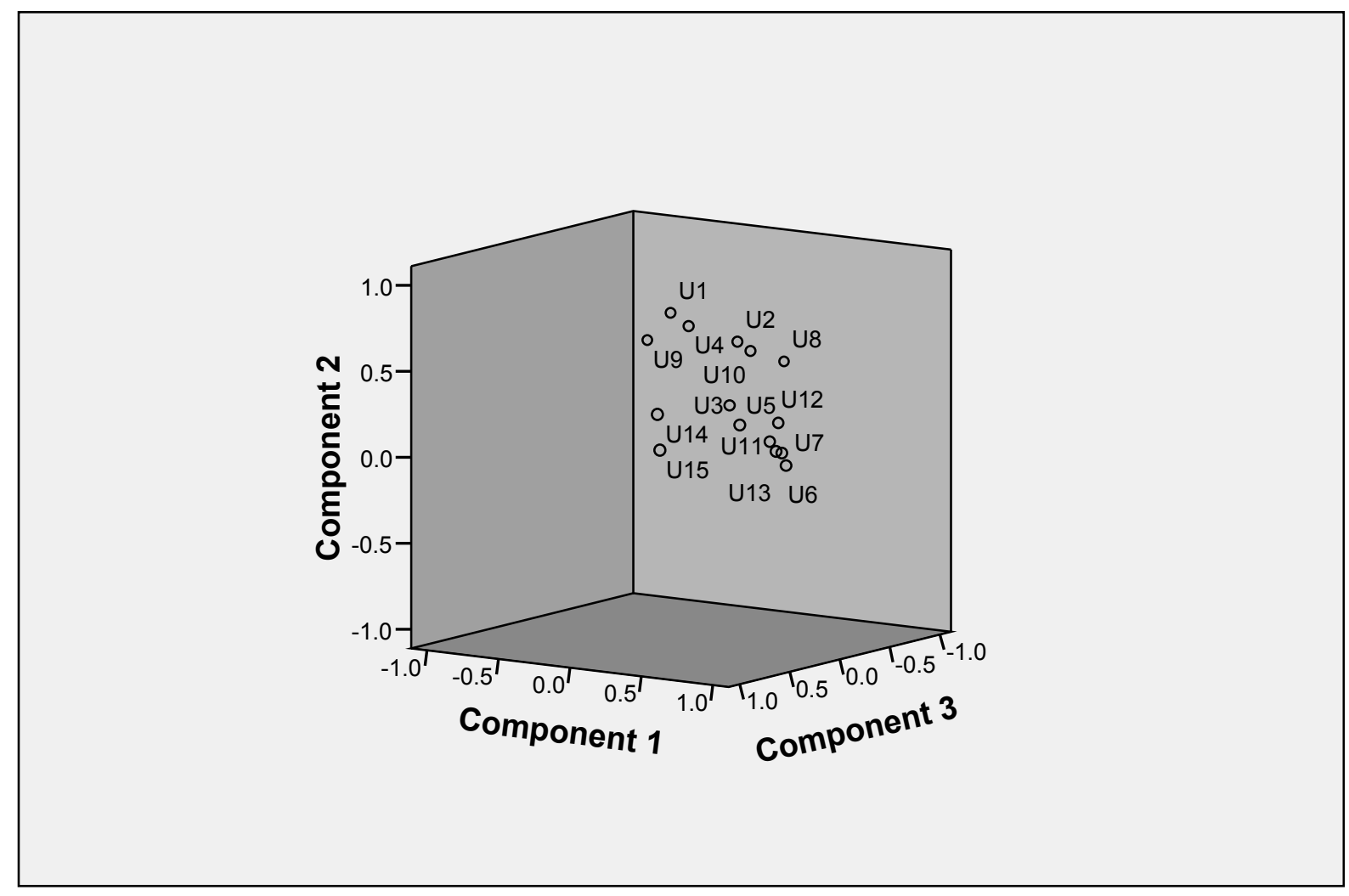




\section{Appendix N: Factor Analysis for motivational factors}

KMO and Bartlett's Test

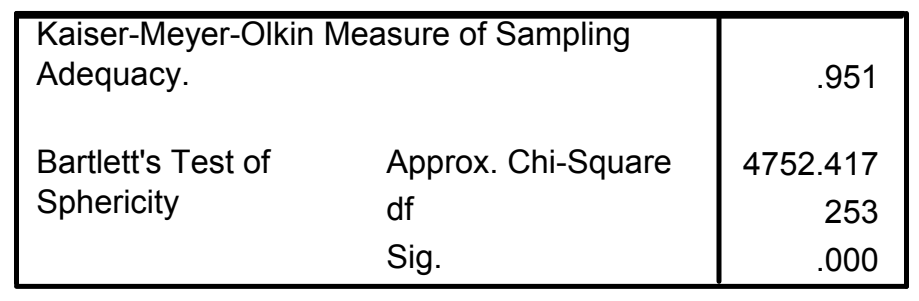

\section{Communalities}

\begin{tabular}{|l|r|r|}
\hline & \multicolumn{1}{|c|}{ Initial } & Extraction \\
\hline 1- Requirement by department or university & 1.000 & .683 \\
2- Administrative encouragement and support & 1.000 & .735 \\
3- Technical support in solving computer & 1.000 & .838 \\
problems & 1.000 & .699 \\
4- Support and encouragement from peers & 1.000 & .761 \\
5- Access to software tools for enhancing & 1.000 & .807 \\
teaching with technology & 1.000 & .760 \\
6- Credit toward promotion and tenure & 1.000 & .769 \\
7- Professional prestige and status & 1.000 & .621 \\
8- Training programs and support & 1.000 & .594 \\
9- Reduced teaching load. & 1.000 & .776 \\
10- Opportunity to improve teaching & & \\
11- Rewards/recognition for innovation in & 1.000 & .788 \\
teaching & 1.000 & .778 \\
12- Time available to learn/pursue the & 1.000 & .665 \\
integration of e-learning technologies & 1.000 & .707 \\
13-Increase in salary. & 1.000 & .744 \\
14- Opportunity to reach new audience that can & 1.000 & .821 \\
not attend classes on campus. & 1.000 & .776 \\
15- Opportunity for scholarly pursuit & 1.000 & .759 \\
16- Funding for materials/expenses & .000 & .744 \\
17- Classroom technology infrastructure (e.g., & .825 \\
wiring , computers, or projectors) & & \\
18- Resources about how to apply technology & 1.000 & \\
in teaching. & & \\
19- Student' access to resources & & \\
20- Student' computer skills & & \\
21- My computer skills & & \\
22- My colleagues' computer skills & & \\
23- Opportunity to enhance communication & & \\
with others. & & \\
\hline
\end{tabular}

Extraction Method: Principal Component Analysis. 
Total Variance Explained

\begin{tabular}{|c|c|c|c|c|c|c|c|c|c|}
\hline \multirow{2}{*}{$\begin{array}{l}\text { C } \\
\text { o } \\
\text { m } \\
\text { p. }\end{array}$} & \multicolumn{3}{|c|}{ Initial Eigenvalues } & \multicolumn{3}{|c|}{$\begin{array}{l}\text { Extraction Sums of Squared } \\
\text { Loadings }\end{array}$} & \multicolumn{3}{|c|}{$\begin{array}{l}\text { Rotation Sums of Squared } \\
\text { Loadings }\end{array}$} \\
\hline & Total & $\begin{array}{c}\% \text { of } \\
\text { Variance }\end{array}$ & $\begin{array}{l}\text { Cumulati } \\
\text { ve } \%\end{array}$ & Total & $\begin{array}{c}\% \text { of } \\
\text { Variance }\end{array}$ & $\begin{array}{l}\text { Cumulati } \\
\text { ve } \%\end{array}$ & Total & $\begin{array}{c}\% \text { of } \\
\text { Variance }\end{array}$ & $\begin{array}{l}\text { Cumulati } \\
\text { ve } \%\end{array}$ \\
\hline 1 & 13.6 & 58.973 & 58.973 & 13.6 & 58.973 & 58.973 & 6.419 & 27.910 & 27.910 \\
\hline 2 & 1.212 & 5.270 & 64.244 & 1.212 & 5.270 & 64.244 & 3.874 & 16.842 & 44.752 \\
\hline 3 & 1.191 & 5.177 & 69.420 & 1.191 & 5.177 & 69.420 & 3.596 & 15.635 & 60.387 \\
\hline 4 & 1.006 & 4.374 & 73.794 & 1.006 & 4.374 & 73.794 & 3.084 & 13.408 & 73.794 \\
\hline 5 & .778 & 3.385 & 77.179 & & & & & & \\
\hline 6 & .616 & 2.680 & 79.859 & & & & & & \\
\hline 7 & .557 & 2.424 & 82.282 & & & & & & \\
\hline 8 & 472 & 2.052 & 84.334 & & & & & & \\
\hline 9 & .467 & 2.033 & 86.366 & & & & & & \\
\hline 10 & .377 & 1.637 & 88.003 & & & & & & \\
\hline 11 & .353 & 1.533 & 89.537 & & & & & & \\
\hline 12 & .300 & 1.305 & 90.841 & & & & & & \\
\hline 13 & .282 & 1.228 & 92.070 & & & & & & \\
\hline 14 & .268 & 1.165 & 93.235 & & & & & & \\
\hline 15 & .257 & 1.119 & 94.353 & & & & & & \\
\hline 16 & .216 & .939 & 95.292 & & & & & & \\
\hline 17 & 195 & .848 & 96.140 & & & & & & \\
\hline 18 & 192 & .835 & 96.976 & & & & & & \\
\hline 19 & 170 & .739 & 97.715 & & & & & & \\
\hline 20 & 167 & .727 & 98.442 & & & & & & \\
\hline 21 & 148 & .644 & 99.086 & & & & & & \\
\hline 22 & 128 & .555 & 99.641 & & & & & & \\
\hline 23 & .083 & .359 & 100.000 & & & & & & \\
\hline
\end{tabular}

Extraction Method: Principal Component Analysis. 


\section{Scree Plot}

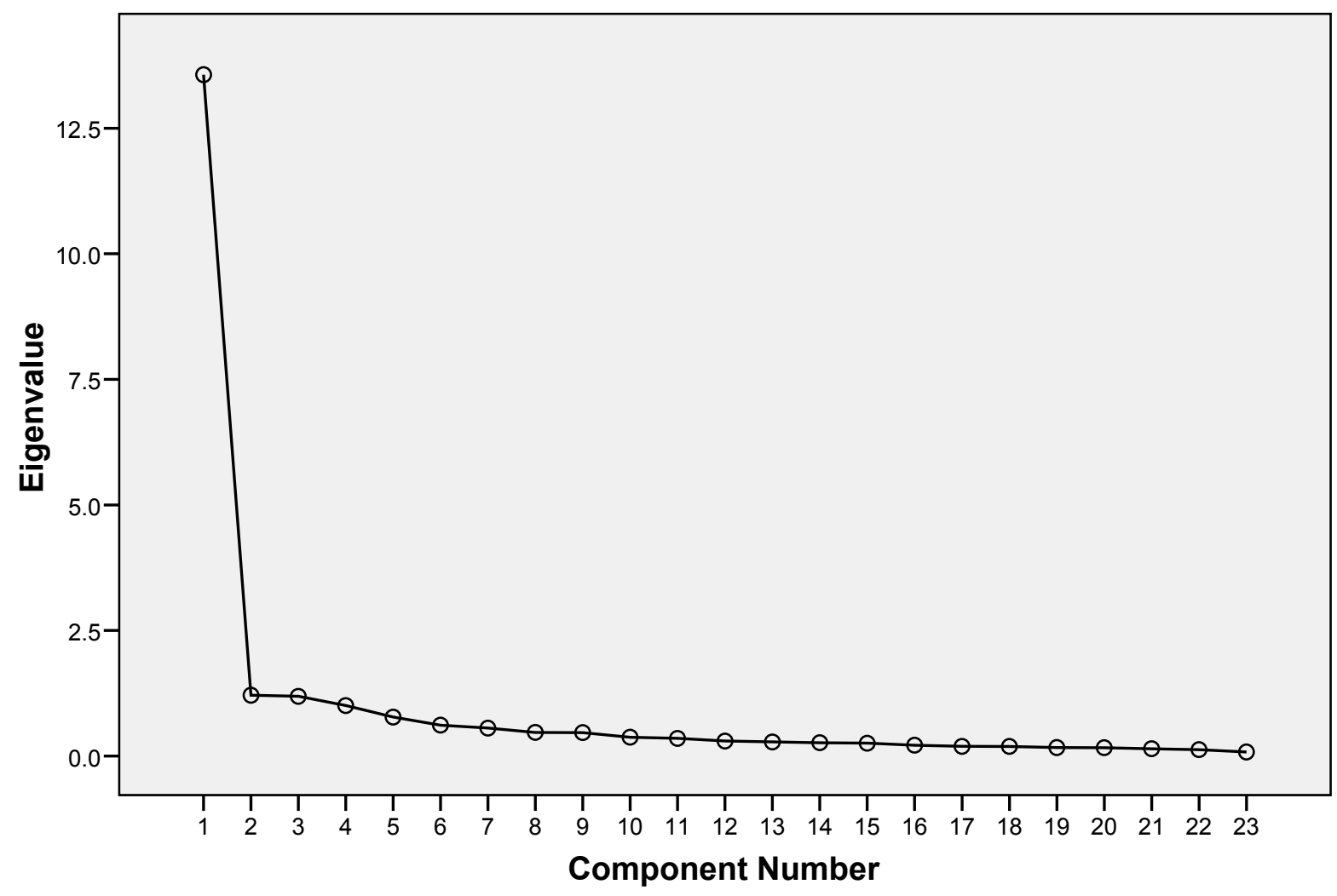




\section{Component Matrix ${ }^{2}$}

\begin{tabular}{|c|c|c|c|c|}
\hline & \multicolumn{4}{|c|}{ Component } \\
\hline & 1 & 2 & 3 & 4 \\
\hline $\begin{array}{l}\text { 1- Requirement by department or } \\
\text { university }\end{array}$ & .595 & .385 & .321 & .280 \\
\hline $\begin{array}{l}\text { 2- Administrative encouragement and } \\
\text { support }\end{array}$ & .704 & .467 & .140 & .045 \\
\hline $\begin{array}{l}\text { 3- Technical support in solving computer } \\
\text { problems }\end{array}$ & .753 & .385 & .056 & -.347 \\
\hline $\begin{array}{l}\text { 4- Support and encouragement from } \\
\text { peers }\end{array}$ & .709 & .338 & .282 & .052 \\
\hline $\begin{array}{l}5 \text { - Access to software tools for enhancing } \\
\text { teaching with technology }\end{array}$ & .798 & .296 & .003 & -.189 \\
\hline 6- Credit toward promotion and tenure & .747 & -.164 & .467 & .059 \\
\hline 7- Professional prestige and status & .628 & -.341 & .500 & -.002 \\
\hline 8- Training programs and support & .823 & -.060 & .065 & -.289 \\
\hline 9- Reduced teaching load. & .727 & -.252 & .031 & -.166 \\
\hline 10- Opportunity to improve teaching & .762 & .057 & -.060 & -.080 \\
\hline $\begin{array}{l}\text { 11- Rewards/recognition for innovation in } \\
\text { teaching }\end{array}$ & .830 & -.224 & .191 & .020 \\
\hline $\begin{array}{l}\text { 12- Time available to learn/pursue the } \\
\text { integration of e-learning technologies }\end{array}$ & .873 & -.070 & -.030 & -.144 \\
\hline 13-Increase in salary. & .781 & -.371 & .137 & .111 \\
\hline $\begin{array}{l}\text { 14- Opportunity to reach new audience } \\
\text { that can not attend classes on campus. }\end{array}$ & .778 & -.239 & -.054 & -.012 \\
\hline 15- Opportunity for scholarly pursuit & .822 & -.078 & -.121 & -.103 \\
\hline 16- Funding for materials/expenses & .853 & -.045 & -.078 & -.095 \\
\hline $\begin{array}{l}\text { 17- Classroom technology infrastructure } \\
\text { (e.g., wiring , computers, or projectors) }\end{array}$ & .864 & .099 & -.197 & -.162 \\
\hline $\begin{array}{l}\text { 18- Resources about how to apply } \\
\text { technology in teaching. }\end{array}$ & .649 & -.095 & -.320 & -.130 \\
\hline 19- Student' access to resources & .861 & -.002 & -.287 & -.035 \\
\hline 20- Student' computer skills & .789 & -.052 & -.344 & .173 \\
\hline 21- My computer skills & .812 & -.008 & -.224 & .258 \\
\hline 22- My colleagues' computer skills & .673 & .029 & -.073 & .547 \\
\hline $\begin{array}{l}\text { 23- Opportunity to enhance } \\
\text { communication with others. }\end{array}$ & .748 & .043 & -.175 & .391 \\
\hline
\end{tabular}

Extraction Method: Principal Component Analysis.

a. 4 components extracted. 
Rotated Component Matrix

\begin{tabular}{|c|c|c|c|c|}
\hline & \multicolumn{4}{|c|}{ Component } \\
\hline & 1 & 2 & 3 & 4 \\
\hline $\begin{array}{l}\text { 1- Requirement by department or } \\
\text { university }\end{array}$ & & & .694 & \\
\hline $\begin{array}{l}\text { 2- Administrative encouragement and } \\
\text { support }\end{array}$ & & & .739 & \\
\hline $\begin{array}{l}\text { 3- Technical support in solving } \\
\text { computer problems }\end{array}$ & 604 & & 669 & \\
\hline $\begin{array}{l}\text { 4- Support and encouragement from } \\
\text { peers }\end{array}$ & & & 696 & \\
\hline $\begin{array}{l}\text { 5- Access to software tools for } \\
\text { enhancing teaching with technology }\end{array}$ & .589 & & .594 & \\
\hline 6- Credit toward promotion and tenure & & .753 & & \\
\hline 7- Professional prestige and status & 173 & .823 & & \\
\hline 8- Training programs and support & .658 & .459 & & \\
\hline 9- Reduced teaching load. & .569 & .506 & & \\
\hline 10- Opportunity to improve teaching & .566 & & & \\
\hline $\begin{array}{l}\text { 11- Rewards/recognition for innovation } \\
\text { in teaching }\end{array}$ & .450 & .644 & & \\
\hline $\begin{array}{l}\text { 12- Time available to learn/pursue the } \\
\text { integration of e-learning technologies }\end{array}$ & .668 & .427 & & \\
\hline 13-Increase in salary. & .414 & .673 & & \\
\hline $\begin{array}{l}\text { 14- Opportunity to reach new audience } \\
\text { that can not attend classes on } \\
\text { campus. }\end{array}$ & .567 & .467 & & \\
\hline 15- Opportunity for scholarly pursuit & .664 & & & \\
\hline 16- Funding for materials/expenses & .653 & & & \\
\hline $\begin{array}{l}17 \text { - Classroom technology } \\
\text { infrastructure (e.g., wiring , computers, } \\
\text { or projectors) }\end{array}$ & .746 & & & \\
\hline $\begin{array}{l}\text { 18- Resources about how to apply } \\
\text { technology in teaching. }\end{array}$ & 674 & & & \\
\hline 19- Student' access to resources & .737 & & & .411 \\
\hline 20- Student' computer skills & .617 & & & .580 \\
\hline 21- My computer skills & .519 & & & .622 \\
\hline 22- My colleagues' computer skills & & & & .763 \\
\hline $\begin{array}{l}\text { 23- Opportunity to enhance } \\
\text { communication with others. }\end{array}$ & & & & .692 \\
\hline
\end{tabular}

Extraction Method: Principal Component Analysis.

Rotation Method: Varimax with Kaiser Normalization.

a. Rotation converged in 12 iterations. 
Component Transformation Matrix

\begin{tabular}{|l|r|r|r|r|}
\hline Component & \multicolumn{1}{|l|}{1} & \multicolumn{1}{|c|}{2} & 3 & \multicolumn{1}{l|}{4} \\
\hline 1 & .653 & .465 & .440 & .405 \\
2 & -.097 & -.591 & .800 & -.034 \\
3 & -.544 & .659 & .407 & -.323 \\
4 & -.518 & .005 & -.022 & .855 \\
\hline
\end{tabular}

Extraction Method: Principal Component Analysis.

Rotation Method: Varimax with Kaiser Normalization.

\section{Component Plot in Rotated Space}

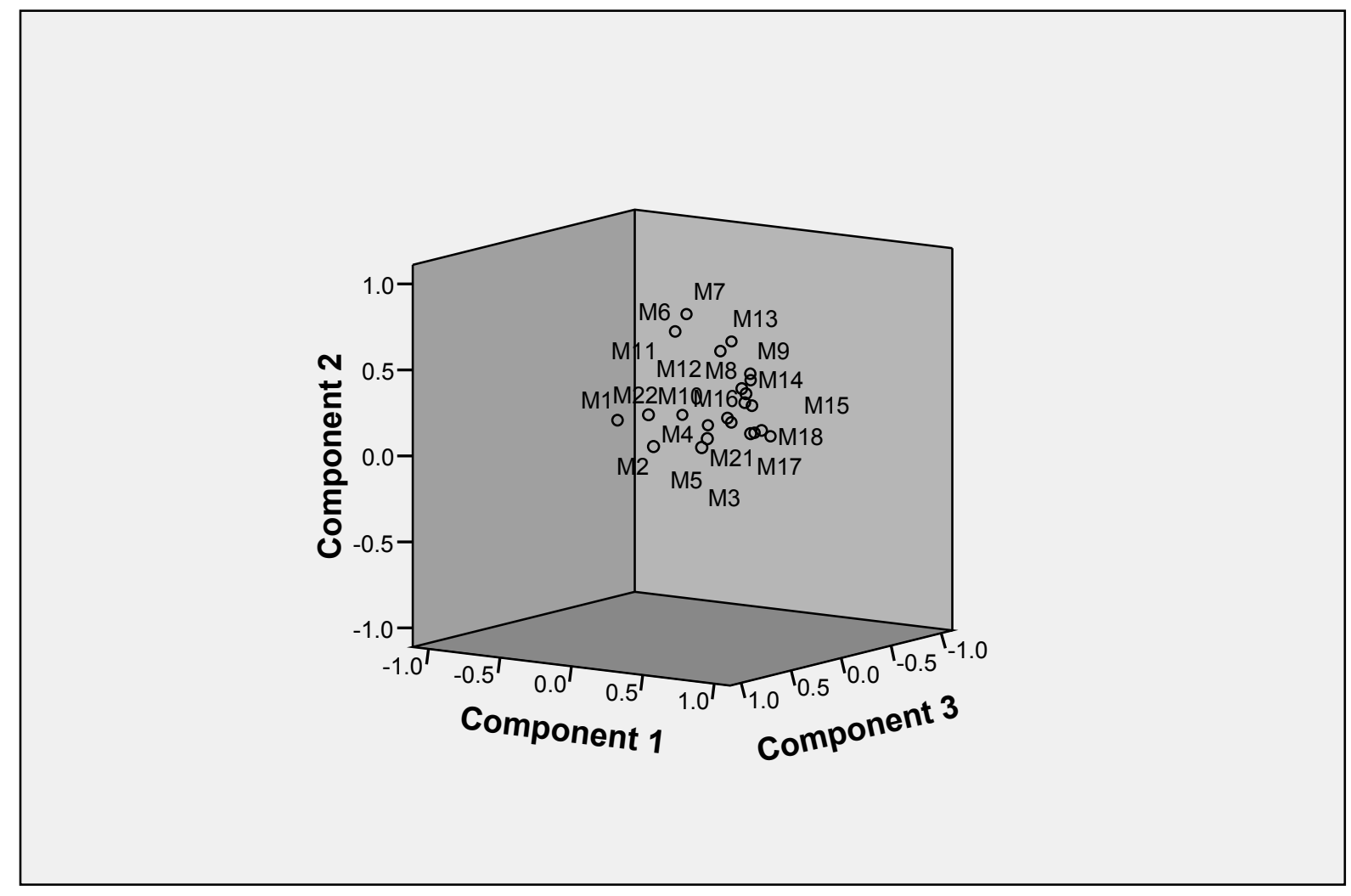




\section{Appendix 0: Factor Analysis for barriers}

KMO and Bartlett's Test

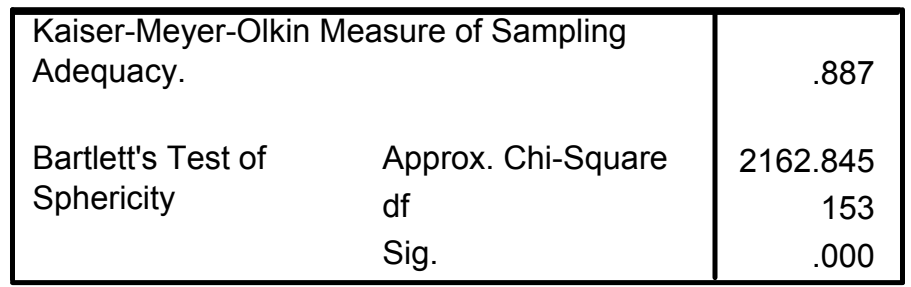

\section{Communalities}

\begin{tabular}{|c|c|c|}
\hline & Initial & Extraction \\
\hline 1- Lack of interest. & 1.000 & .684 \\
\hline 2-Lack of time to learn new technology & 1.000 & .564 \\
\hline $\begin{array}{l}\text { 3- Negative comments made by colleagues } \\
\text { about e-learning technologies. }\end{array}$ & 1.000 & .698 \\
\hline $\begin{array}{l}\text { 4- Lack of support and encouragement from } \\
\text { administrative. }\end{array}$ & 1.000 & .473 \\
\hline $\begin{array}{l}\text { 5- Lack of support and encouragement from } \\
\text { peers. }\end{array}$ & 1.000 & .673 \\
\hline $\begin{array}{l}\text { 6- Lack of instructors' technological } \\
\text { knowledge. }\end{array}$ & 1.000 & .513 \\
\hline $\begin{array}{l}\text { 7- Lack of students' technological } \\
\text { knowledge. }\end{array}$ & 1.000 & .563 \\
\hline 8- Lack of training programs. & 1.000 & .764 \\
\hline $\begin{array}{l}\text { 9- Lack of face-to-face interaction in } \\
\text { e-learning courses. }\end{array}$ & 1.000 & .632 \\
\hline $\begin{array}{l}\text { 10- Lack of credit toward promotion and } \\
\text { tenure. }\end{array}$ & 1.000 & .696 \\
\hline 11- Lack of funding for materials/expenses. & 1.000 & .631 \\
\hline $\begin{array}{l}\text { 12- Lack of rewards/recognition for } \\
\text { innovation in teaching }\end{array}$ & 1.000 & .596 \\
\hline 13- Concern about course quality. & 1.000 & .583 \\
\hline $\begin{array}{l}\text { 14- Lack of technical support in solving } \\
\text { computer problems. }\end{array}$ & 1.000 & .660 \\
\hline 15- Lack of technological infrastructure. & 1.000 & .822 \\
\hline 16- Lack of Student' access to resources. & 1.000 & .825 \\
\hline $\begin{array}{l}\text { 17- Lack of resources about how to apply } \\
\text { technology in teaching. }\end{array}$ & 1.000 & .755 \\
\hline 18- Security concerns. & 1.000 & .464 \\
\hline
\end{tabular}

Extraction Method: Principal Component Analysis. 
Total Variance Explained

\begin{tabular}{|c|c|c|c|c|c|c|c|c|c|}
\hline \multirow{2}{*}{$\begin{array}{l}\text { Co } \\
\text { m } \\
\text { p. }\end{array}$} & \multicolumn{3}{|c|}{ Initial Eigenvalues } & \multicolumn{3}{|c|}{$\begin{array}{c}\text { Extraction Sums of Squared } \\
\text { Loadings }\end{array}$} & \multicolumn{3}{|c|}{$\begin{array}{l}\text { Rotation Sums of Squared } \\
\text { Loadings }\end{array}$} \\
\hline & Total & $\begin{array}{c}\% \text { of } \\
\text { Variance }\end{array}$ & $\begin{array}{l}\text { Cumulati } \\
\text { ve } \%\end{array}$ & Total & $\begin{array}{c}\% \text { of } \\
\text { Variance }\end{array}$ & $\begin{array}{l}\text { Cumulati } \\
\text { ve } \%\end{array}$ & Total & $\begin{array}{c}\% \text { of } \\
\text { Variance }\end{array}$ & $\begin{array}{l}\text { Cumulati } \\
\text { ve } \%\end{array}$ \\
\hline 1 & 7.110 & 39.501 & 39.501 & 7.110 & 39.501 & 39.501 & 4.090 & 22.720 & 22.720 \\
\hline 2 & 2.037 & 11.316 & 50.817 & 2.037 & 11.316 & 50.817 & 2.804 & 15.577 & 38.296 \\
\hline 3 & 1.420 & 7.887 & 58.704 & 1.420 & 7.887 & 58.704 & 2.394 & 13.302 & 51.598 \\
\hline 4 & 1.029 & 5.718 & 64.422 & 1.029 & 5.718 & 64.422 & 2.308 & 12.823 & 64.422 \\
\hline 5 & .907 & 5.039 & 69.460 & & & & & & \\
\hline 6 & .839 & 4.660 & 74.120 & & & & & & \\
\hline 7 & .704 & 3.909 & 78.030 & & & & & & \\
\hline 8 & .612 & 3.399 & 81.429 & & & & & & \\
\hline 9 & .533 & 2.961 & 84.390 & & & & & & \\
\hline 10 & .482 & 2.675 & 87.065 & & & & & & \\
\hline 11 & .442 & 2.454 & 89.520 & & & & & & \\
\hline 12 & .401 & 2.230 & 91.749 & & & & & & \\
\hline 13 & .333 & 1.852 & 93.601 & & & & & & \\
\hline 14 & .306 & 1.702 & 95.303 & & & & & & \\
\hline 15 & .270 & 1.497 & 96.800 & & & & & & \\
\hline 16 & .249 & 1.385 & 98.185 & & & & & & \\
\hline 17 & .216 & 1.199 & 99.384 & & & & & & \\
\hline 18 & .111 & .616 & 100.000 & & & & & & \\
\hline
\end{tabular}

Extraction Method: Principal Component Analysis. 


\section{Scree Plot}

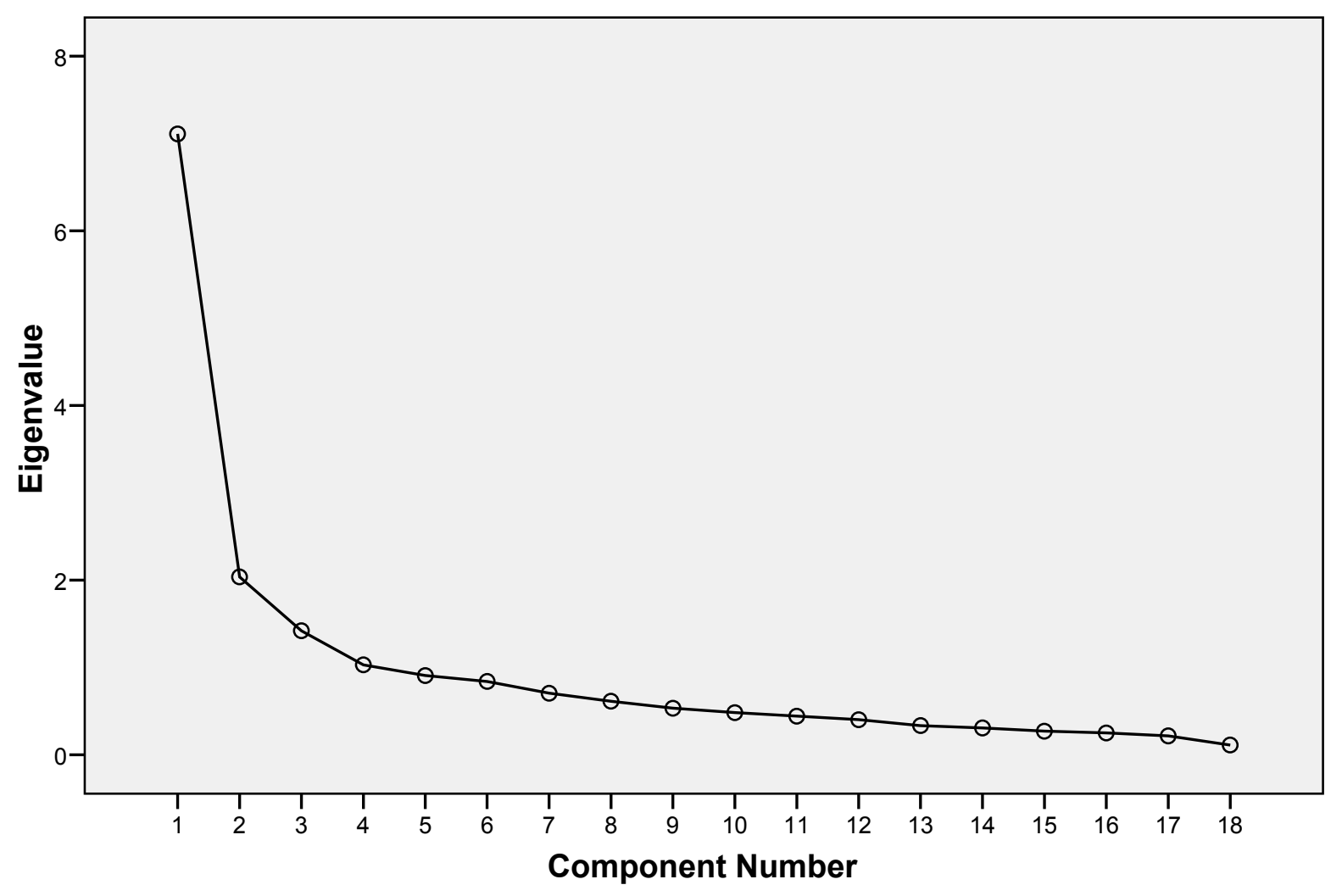




\section{Component Matrix}

\begin{tabular}{|c|c|c|c|c|}
\hline & \multicolumn{4}{|c|}{ Component } \\
\hline & 1 & 2 & 3 & 4 \\
\hline 1- Lack of interest. & .494 & .089 & .642 & -.138 \\
\hline $\begin{array}{l}\text { 2-Lack of time to learn new } \\
\text { technology }\end{array}$ & .612 & -.028 & .362 & -.240 \\
\hline $\begin{array}{l}\text { 3- Negative comments made by } \\
\text { colleagues about e-learning } \\
\text { technologies. }\end{array}$ & .412 & .643 & .312 & -.130 \\
\hline $\begin{array}{l}\text { 4- Lack of support and } \\
\text { encouragement from } \\
\text { administrative. }\end{array}$ & .601 & .148 & .076 & -.290 \\
\hline $\begin{array}{l}\text { 5- Lack of support and } \\
\text { encouragement from peers. }\end{array}$ & .498 & .638 & .114 & -.069 \\
\hline $\begin{array}{l}\text { 6- Lack of instructors' } \\
\text { technological knowledge. }\end{array}$ & .679 & .115 & -.060 & -.188 \\
\hline $\begin{array}{l}\text { 7- Lack of students' } \\
\text { technological knowledge. }\end{array}$ & .645 & .190 & -.224 & -.247 \\
\hline 8- Lack of training programs. & .744 & -.169 & -.308 & -.295 \\
\hline $\begin{array}{l}\text { 9- Lack of face-to-face } \\
\text { interaction in e-learning } \\
\text { courses. }\end{array}$ & .584 & -.015 & -.490 & -.224 \\
\hline $\begin{array}{l}\text { 10- Lack of credit toward } \\
\text { promotion and tenure. }\end{array}$ & .447 & .484 & -.349 & .374 \\
\hline $\begin{array}{l}\text { 11- Lack of funding for } \\
\text { materials/expenses. }\end{array}$ & .761 & -.087 & -.173 & .119 \\
\hline $\begin{array}{l}\text { 12- Lack of rewards/recognition } \\
\text { for innovation in teaching }\end{array}$ & .551 & .369 & -.268 & .290 \\
\hline $\begin{array}{l}\text { 13- Concern about course } \\
\text { quality. }\end{array}$ & .486 & -.038 & .341 & .479 \\
\hline $\begin{array}{l}\text { 14- Lack of technical support in } \\
\text { solving computer problems. }\end{array}$ & .722 & -.365 & -.023 & .072 \\
\hline $\begin{array}{l}\text { 15- Lack of technological } \\
\text { infrastructure. }\end{array}$ & .769 & -.443 & .143 & .120 \\
\hline $\begin{array}{l}\text { 16- Lack of Student' access to } \\
\text { resources. }\end{array}$ & .792 & -.436 & .060 & .069 \\
\hline $\begin{array}{l}\text { 17- Lack of resources about } \\
\text { how to apply technology in } \\
\text { teaching. }\end{array}$ & .775 & -.373 & .032 & .118 \\
\hline 18- Security concerns. & .532 & .262 & .066 & .328 \\
\hline
\end{tabular}

Extraction Method: Principal Component Analysis.

a. 4 components extracted. 
Rotated Component Matrix

\begin{tabular}{|c|c|c|c|c|}
\hline & \multicolumn{4}{|c|}{ Component } \\
\hline & 1 & 2 & 3 & 4 \\
\hline 1- Lack of interest. & & & .735 & \\
\hline $\begin{array}{l}\text { 2-Lack of time to learn new } \\
\text { technology }\end{array}$ & .426 & & .568 & \\
\hline $\begin{array}{l}\text { 3- Negative comments made } \\
\text { by colleagues about e-learning } \\
\text { technologies. }\end{array}$ & & & .734 & \\
\hline $\begin{array}{l}\text { 4- Lack of support and } \\
\text { encouragement from } \\
\text { administrative. }\end{array}$ & & .439 & .467 & \\
\hline $\begin{array}{l}\text { 5- Lack of support and } \\
\text { encouragement from peers. }\end{array}$ & & & .605 & .499 \\
\hline $\begin{array}{l}\text { 6- Lack of instructors' } \\
\text { technological knowledge. }\end{array}$ & & .501 & & \\
\hline $\begin{array}{l}\text { 7- Lack of students' } \\
\text { technological knowledge. }\end{array}$ & & .618 & & \\
\hline 8- Lack of training programs. & .427 & .750 & & \\
\hline $\begin{array}{l}\text { 9- Lack of face-to-face } \\
\text { interaction in e-learning } \\
\text { courses. }\end{array}$ & & .736 & & \\
\hline $\begin{array}{l}\text { 10- Lack of credit toward } \\
\text { promotion and tenure. }\end{array}$ & & & & .804 \\
\hline $\begin{array}{l}11 \text { - Lack of funding for } \\
\text { materials/expenses. }\end{array}$ & .555 & .428 & & \\
\hline $\begin{array}{l}\text { 12- Lack of } \\
\text { rewards/recognition for } \\
\text { innovation in teaching }\end{array}$ & & & & .696 \\
\hline $\begin{array}{l}\text { 13- Concern about course } \\
\text { quality. }\end{array}$ & .582 & & & \\
\hline $\begin{array}{l}\text { 14- Lack of technical support in } \\
\text { solving computer problems. }\end{array}$ & .725 & & & \\
\hline $\begin{array}{l}\text { 15- Lack of technological } \\
\text { infrastructure. }\end{array}$ & .860 & & & \\
\hline $\begin{array}{l}\text { 16- Lack of Student' access to } \\
\text { resources. }\end{array}$ & .835 & & & \\
\hline $\begin{array}{l}\text { 17- Lack of resources about } \\
\text { how to apply technology in } \\
\text { teaching. }\end{array}$ & .793 & & & \\
\hline 18- Security concerns. & & & & .548 \\
\hline
\end{tabular}

Extraction Method: Principal Component Analysis.

Rotation Method: Varimax with Kaiser Normalization.

a. Rotation converged in 7 iterations. 
Component Transformation Matrix

\begin{tabular}{|l|r|r|r|r|}
\hline Component & \multicolumn{1}{|c|}{1} & \multicolumn{1}{|c|}{2} & \multicolumn{1}{c|}{3} & \multicolumn{1}{c|}{4} \\
\hline 1 & .658 & .518 & .395 & .378 \\
2 & -.635 & -.001 & .476 & .609 \\
3 & .235 & -.609 & .695 & -.300 \\
4 & .330 & -.601 & -.366 & .629 \\
\hline
\end{tabular}

Extraction Method: Principal Component Analysis.

Rotation Method: Varimax with Kaiser Normalization.

\section{Component Plot in Rotated Space}

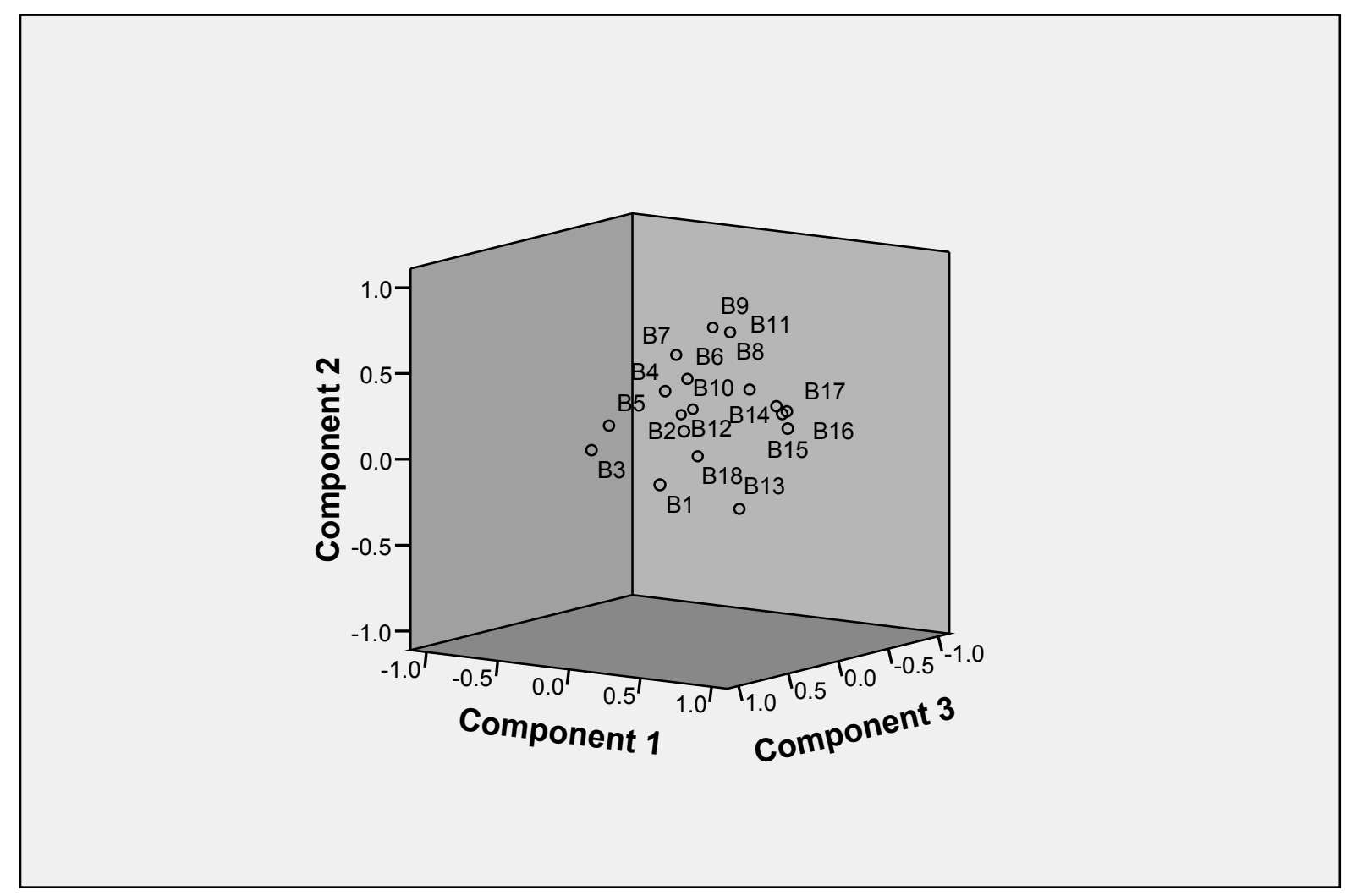




\title{
Appendix P: Curriculum Vitae
}

\author{
Salem A. Albalwi \\ 1342 Headlee Ave - Morgantown, WV 26505 \\ $304-216$ \\ e-mail: salbalwi@mix.wvu.edu
}

\section{EDUCATION :}

West Virginia University Morgantown, West Virginia, USA

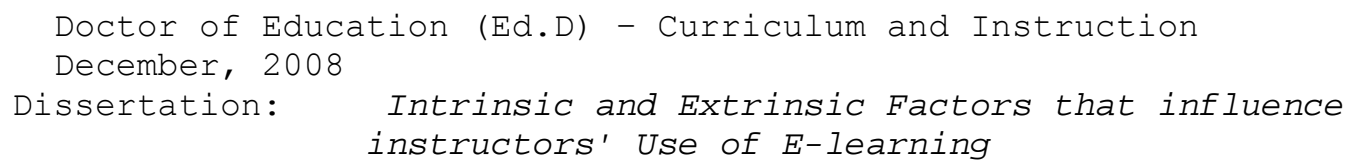


West Virginia University Morgantown, West Virginia, USA

Master of Arts - Secondary Education

May, 2006

\author{
King Abdulaziz University Jeddah, Kingdom of Saudi Arabia \\ (Teachers College) \\ Bachelor of Computer Science \\ February, 2003
}

\title{
Experience
}

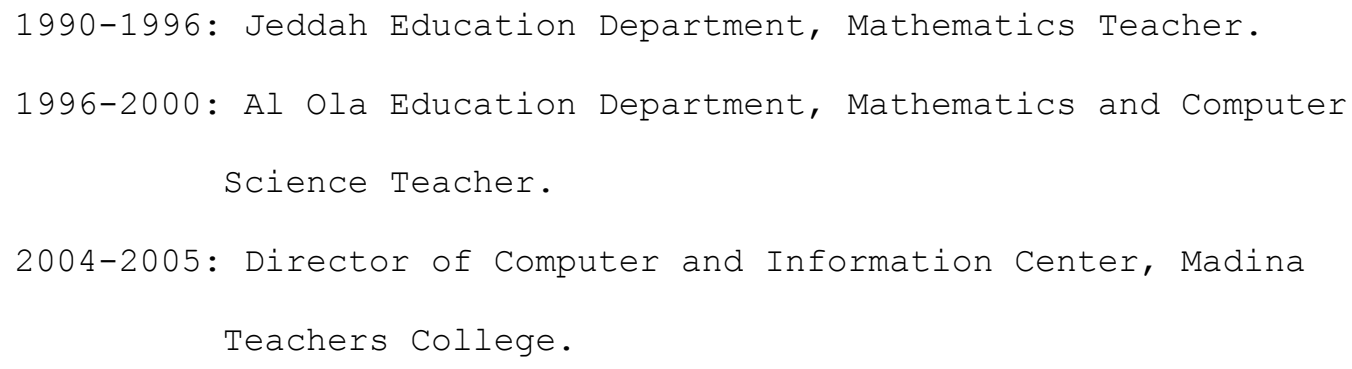

\section{Conferences:}

(SITE) conference, Society for Information Technology \& Teacher Education, Orlando, Florida, USA, 2006

(MAA) conference, Mathematical Association of America, Pensacola,

$$
\text { Florida, USA, } 2008
$$

\section{Membership:}

(AERA) American Educational Research Association, USA

(AACE) Association for the Advancement of Computing in Education, USA

\section{Interests:}

- E-learning

- Computerized Testing

- Programming and Data Bases

- $\quad$ Statistical Software (SPSS, STATA, SAS) 